Portland State University

PDXScholar

1-30-1995

\title{
Sustainable Development in Sub-Saharan Africa: Strategies for Self-help in Food Production, Case Study of Kenya
}

Dieudonne Mayi

Portland State University

Follow this and additional works at: https://pdxscholar.library.pdx.edu/open_access_etds

Part of the Political Science Commons

Let us know how access to this document benefits you.

Recommended Citation

Mayi, Dieudonne, "Sustainable Development in Sub-Saharan Africa: Strategies for Self-help in Food Production, Case Study of Kenya" (1995). Dissertations and Theses. Paper 5188.

https://doi.org/10.15760/etd.7064

This Thesis is brought to you for free and open access. It has been accepted for inclusion in Dissertations and Theses by an authorized administrator of PDXScholar. Please contact us if we can make this document more accessible: pdxscholar@pdx.edu. 


\section{THESIS APPROVAL}

The abstract and thesis of Dieudonné Mayi for the Master of Arts in Political Science presented January 30,1995 , and accepted by the thesis committe and the department.

COMMITTEE APPROVALS:

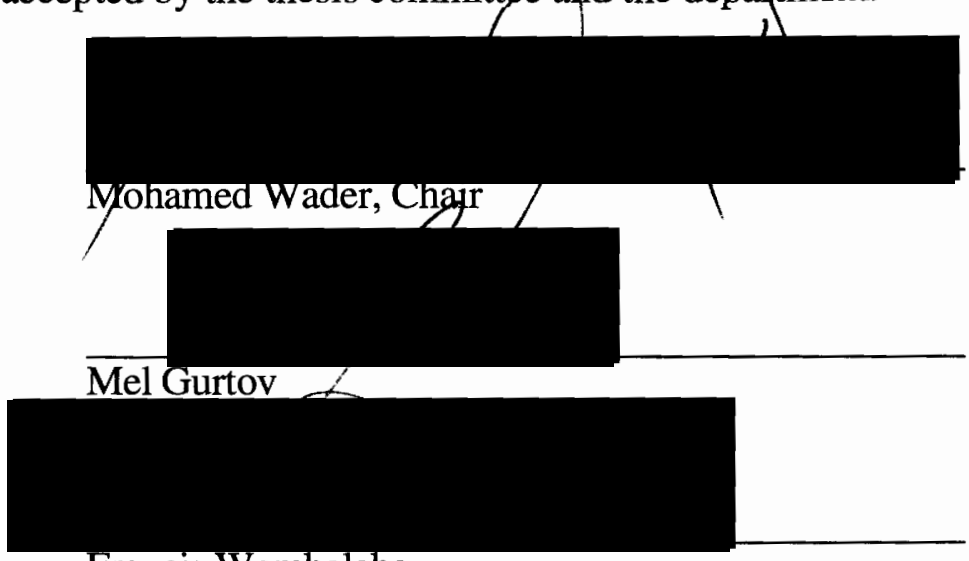

Francis Wambalaba

DEPARTMENT APPROVAL:

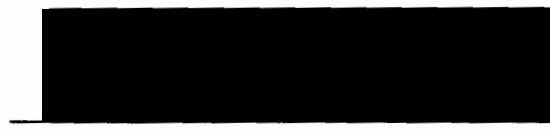

Nelson Crick

Representative of the Office of Graduate Studies

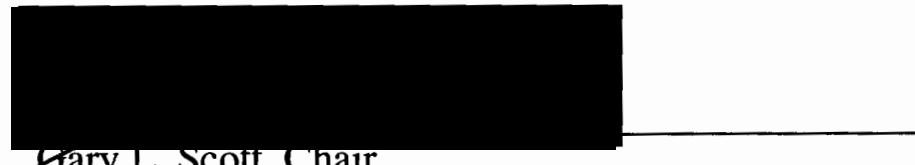

Jary L. Scoti, Chair

Department of Political Science

$* * * * * * * * * * * * * * * * * * * * * * * * * * * * * * * * * * * * * * * * * * * * * * * * * * * * * * * * * * * * * * * * * * * * * * * * * *$

\section{ACCEPTED FOR PORTLAND STATE UNIVERSITY LIBRARY}

by

on

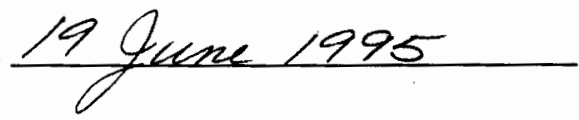




\section{THESIS ABSTRACT}

An abstract of the thesis of Dieudonné Mayi for the Master of Arts in Political Science presented January 30, 1995.

Title: Sustainable Development in Sub-Saharan Africa: Strategies for Self-help in Food Production, Case Study of Kenya

This thesis analyses the food crisis in sub-Saharan Africa in the 1980s and 1990s, identifies roots of the problem, and proposes strategies of sustainable development based on self-sufficiency in food production for domestic needs. The main goal of this research has been to devise development strategies centered on development of the food production sector. The thesis strongly suggests that countries of the region should consider developing the food production sector to experience any meaningful development, and to escape a dark future of food shortages and food dependency on developed economies. Investigation into Development Economics, Dependency, Underdevelopment, and Modernization theories has provided a basis to justify that improvement of the food production sector is an urgent necessity for sub-Saharan African countries.

The thesis uses a comparative analytical methodology based on a historical study of Kenya from the colonial period to the 1990s. The food crisis is identified as a common problem for many countries in sub-Saharan Africa and its general causes are investigated:

(1) low output productivity of traditional methods and technology, (2) harsh ecological environment with frequent droughts and soil erosion, (3) neglect of food production in the policies and priorities of governments, (4) poor marketing and distribution of foodstuffs, 
(5) fast population growth. Kenya is then used as a model to confirm the hypothesis that roots of the crisis are strongly linked to the colonial setting of these economies as cash crop and raw material producers. Also, neglect of the food production sector in government policy is matched in the Kenyan case.

Kenya's food crisis can be explained by two sets of factors. On the input side of the food production sector, reasons found were (1) government emphasis on cash crops to the neglect of food production, and (2) underdeveloped technology and agricultural methods used in food production. On the output side, food shortages are due to (1) an inefficient marketing and distribution system, (2) inefficient pricing policies, and (3) fast population growth.

A model of five solutions is presented which puts emphasis, on the input side, on (1) a shift of policies from cash crop production to accommodate food crop production as a viable economic development policy, (2) curbing food imports, and (3) boosting domestic food production by empowering women, attracting men to the food production activity, reorganizing production, and improving agricultural technology and methods. On the output side the solutions call for (4) reorganizing and improving the distribution, and marketing, and pricing of foodstuffs, and (5) developing rural economies around the food production sector and the agribusiness industry. 
SUSTAINABLE DEVELOPMENT IN SUB-SAHARAN AFRICA: STRATEGIES FOR SELF-HELP IN FOOD PRODUCTION, CASE STUDY OF KENYA

by

DIEUDONNE MAYT

A thesis submitted in partial fulfillment of the

requirements for the degree of

\author{
MASTER OF ARTS \\ in \\ POLITICAL SCIENCE
}

Portland State University

1995 


\section{ACKNOWLEDGMENTS}

In remembrance of my late father, Michel Gweth Bi Bòdò Ndóga Masúsi Mayúbda Ngwém Nyébél Súlúk who raised me to be a man and gave me early words of life.

I express gratitude to my adviser Dr. Mohamed Wader who encouraged and guided me throughout this endeavor. I also thank Dr. Mel Gurtov as my second field adviser and member of the committee for his suggestions and critiques. To Dr. Francis Wambalaba and Dr. Nelson Crick, I present my gratitude for their critiques and suggestions to make this thesis a better work.

In this endeavor as in many others, my dear wife Bibiane Mayi and my son Christian Gweth-Mayi have always been of great motivation to me. Could they find in this page my sincere recognition that they mean so much to me.

I owe much to Dr. Marek A. Perkowski, my academic adviser in Electrical Engineering, who has supported me in this program. I present gratitude to my SOL family Dr. Carol Cross, Dee Brightman, and Kattleen Elliot for their support and encouragement. Mrs. Miyako Hayashi Bliesner deserves my sincere gratitude for her spiritual support.

I thank the Government of Cameroon and US Agency for International Development for sponsoring my training program in the USA from June 1989 to May 1995.

To Africa I owe all respect, and consideration with the hope that her people will benefit the fruits of their land, achieve basic needs, democracy, and development in the silent revolution to the 21 st century... The ultimate victory against all odds lies in her people.

Portland, Oregon

Dieudonné Mayi 
TABLE OF CONTENTS

PAGE

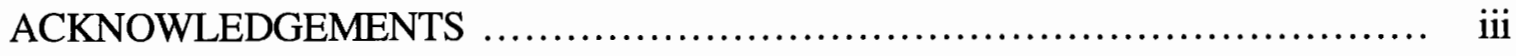

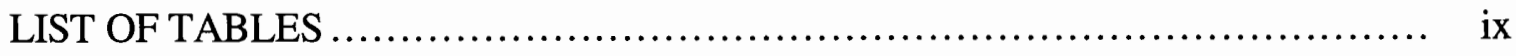

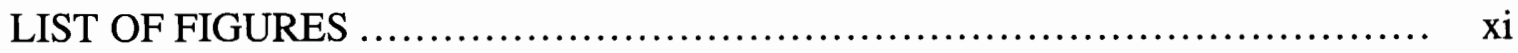

\section{CHAPTER}

INTRODUCTION

IMPORTANCE OF FOOD PRODUCTION

IN ECONOMIC DEVELOPMENT ................................ 2

FOOD PRODUCTION AND THE REALM OF POLITICS ......... 4

FOOD PRODUCTION AND COMPARATIVE POLITICS ........ 7

THE SUB-SAHARAN AFRICAN CRISIS .................... 11

A SURVEY OF THE KENYAN SITUATION ................. 13

GOALS OF THE THESIS …................................... 16

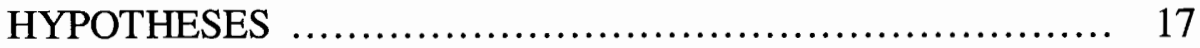

METHODOLOGY ........................................ 18

II COLONIAL KENYA (1895-1963): POLITICAL ECONOMY,

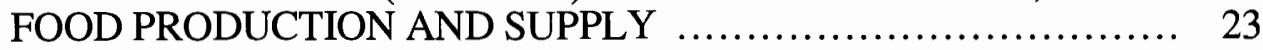

INTRODUCTION E...................................... 23

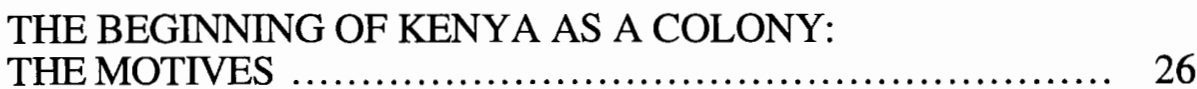

THE COLONIAL STATE: POLICIES, CONFLICTS
AND CONTRADICTIONS $\ldots \ldots \ldots \ldots \ldots \ldots \ldots \ldots \ldots \ldots \ldots \ldots \ldots \ldots \ldots \ldots \ldots \ldots \ldots \ldots \ldots \ldots \ldots$

THE EVOLUTION OF AFRICAN
POLITICAL ORGANIZATION .............................. 40

THE ECONOMY OF COLONIAL KENYA:
MAJOR DEVELOPMENTS …............................... 46

THE AGRICULTURE DEVELOPMENT POLICY .............. 48 
FOOD PRODUCTION FOR DOMESTIC NEEDS

IMPACT OF POLTICS ON FOOD PRODUCTION

IN THE COLONIAL STATE

III POST-INDEPENDENCE KENYA (1963 - 1990s): POLITICS, ECONOMY, FOOD PRODUCTION AND SUPPLY ................ 66

THE KENYATTA ERA (1963-1978)................................. 66

CONTEMPORARY KENYA $(1979-1990 s)$................... 90

CONCLUSIONS TO DRAW FROM COLONIAL LEGACY ..... 110

IMPACT OF POLITICS ON FOOD PRODUCTION IN

POST-INDEPENDENCE KENYA 114

IV A CASE FOR DEVELOPMENT POLICIES THAT CAPITALIZE ON BOOSTING UP DOMESTIC FOOD PRODUCTION IN SUB-SAHARAN AFRICA 118

SUB-SAHARAN AFRICA'S FOOD CRISIS: 1970s-1990s 119 UNDERSTANDING THE ROOTS OF THE AFRICAN FOOD CRISIS 125

SOLUTIONS PROPOSED TO ADDRESS THE FOOD CRISIS IN SUB-SAHARAN AFRICA 140

SUSTAINED FOOD PRODUCTION BASE AND NATIONAL ECONOMIC DEVELOPMENT: THE IMPORTANCE OF DEVELOPING THE FOOD PRODUCTION SECTOR

AGRICULTURAL DEVELOPMENT: WESTERN COUNTRIES' EXPERIENCE Vs DEVELOPING COUNTRIES

FOR POLICIES TO BOOST UP FOOD PRODUCTION IN SUB-SAHARAN AFRICA: INWARD LOOKING SOLUTIONS AND STRATEGIES

A CONCEPTUAL MODEL OF NEW STRATEGIES TO IMPROVE FOOD PRODUCTION IN SUB-SAHARAN AFRICA

ISSUES OF IMPORTANCE IN FOOD PRODUCTION 172

A CONCEPTUAL MODEL FOR IMPROVEMENT OF 177 FOOD PRODUCTION IN SUB-SAHARA AFRICA

DISCUSSION OF THE BENEFITS AND TRADEOFFS OF THE NEW STRATEGIES 203

VI CONCLUSIONS 215 


\section{APPENDICES}

A TABLES ...

226

B FIGURES

241 


\section{LIST OF TABLES}

\section{TABLE}

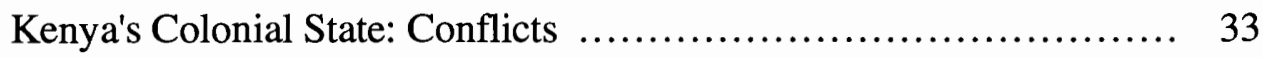

II Kenya's Colonial State: Contradictions ........................... 34

III Gross National Product and Official Development .................. 226

IV External Debt Indicators, 1977-87 ..................................... 227

V Kenya: External Debt in Million US Dollars

(Pulbic and Publicly Guaranteed Long-term) ..................... 228

VI Kenya: Gross Domestic Product by Kind of Economic Activity ........ 228

VII Self-sufficiency Ratios ........................................... 229

VIII Per Capita Calories Available from Cereals ......................... 229

IX Cereal Food Aid to Tropical Africa 1970/1-72/3 to

$\mathrm{X} \quad$ Portion of Recipients Food Aid (tonnage) from

XI Per Capita Food from the United States, 1966-1983 ................ 232

XII Food Imports and Food Aid Dependency ......................... 233

XIII Food Aid Represented as a Percentage of Domestic Food Production .. 234

XIV Expenditures by Activity Group, Cohort Sample, 1985-1987 ......... 235

XV Kenya: Balance of Payments 1967-1973 ........................... 235

XVI Kenya: Balance of Payments 1983-1989 ........................... 236

XVII Kenya's Debt Position in 1987 .................................... 236

XVIII A Statistical Guide to a Continent in Crisis (Kenya: Finances) ........ 237

XIX Debt Service Ratios .................................................. 237

XX Commercial Food Imports and Total

Merchandise Imports , 1966-83 ............................... 238

XXI Input Uses: Land, Tractors, and Fertilizers, $1981 \ldots \ldots \ldots \ldots \ldots \ldots \ldots 238$

XXII A Statistical Guide to a Continent in Crisis (Kenya: Production) ....... 239

XXIII Distribution of Agricultural Inputs ........................................ 239

XXIV Causes of the Food Crisis in Kenya ...................................... 111 
XXV Modern Input Use, Africa, Asia, and South America, 1977 ........... 121

XXVI Modern Input Use, Africa, Asia, and South America, 1986 ........... 121

XXVII Modern Input Use, Africa, Asia, and South America, 1991 ........... 122

XXVIII American Household Food Budget as a Percentage of Total Income (1986-88) ...................................... 159

XXIX A Conceptual Categorization of Roads in Sub-Saharan Africa ........... 195

XXX Kenya: Military Expenditures as a Percentage of Government Total.... 240 


\section{LIST OF FIGURES}

\section{FIGURE}

1.a Official Map of Contemporary Kenya ................................... 241

1.b Kenya: Geographical Location in the East African Region ............ 242

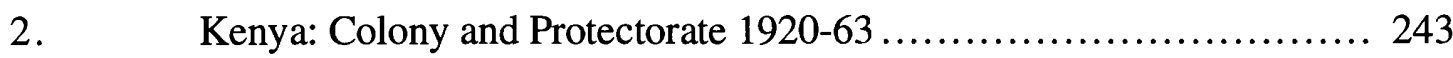

3. African Food Crisis Map .................................... 244

4. Africa: Nutrition Compared with other Continents, 1989 ............ 243

5. Africa: Population and Projections, 1990s ......................... 243

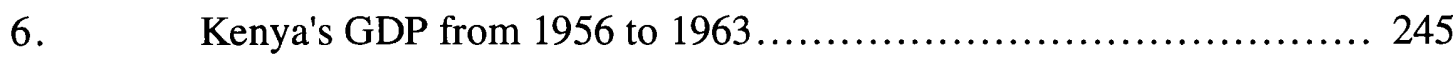

7. Kenya's GDP: Sector Shares 1964, 1969-73.......................... 246

8. Kenya: Population and Growth Rates, 1931-1974...................... 246

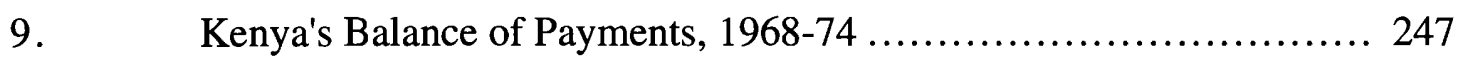

10. Kenya's Balance of Trade, 1969-74 ............................... 247

11. Kenya's Terms of Trade 1970-74 ............................. 247

12. Kenya: Domestic Exports by Principal Commodities, 1964-73 ........ 248

13. Kenya's Coffee Production, 1963-74 ......................... 248

14. Kenya: The Development of Smallholder Tea, 1964-74................. 248

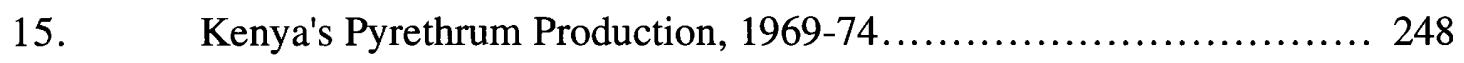

16. Kenya: Exports of Fresh Horticultural Produce, 1968-74 ............ 248

17. Ecological Zones of Kenya....................................... 249

18. Kenya: Import Price Index, 1970-74 ........................... 249

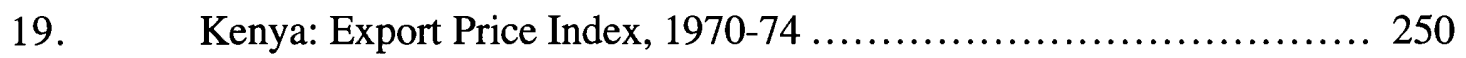

20. Kenya: Net Food imports 1964-73 ................................... 250

21. Kenya: Delivery of Sheep, Lambs and Goats, 1966-74_............ 250

22. Kenya's Marketing Network....................................... 251

23. Organization of the Kenya's Government, 1983 .................. 252

24. Rain Water Retention Reservoir ................................ 252

25. A Layered Distribution Model for Foodstuffs ............................ 253

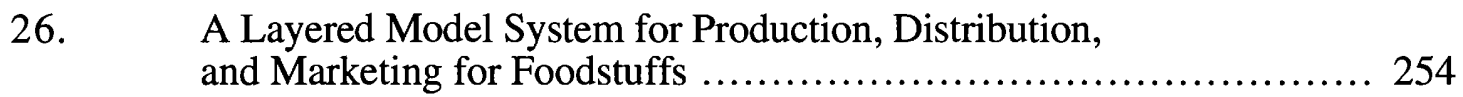




\section{CHAPTER I}

\section{INTRODUCTION}

This thesis focuses on food production as a development strategy that should be emphasized by governments in sub-Saharan Africa to provide populations with self-help for their food needs. The major recommendation I am making is to shift emphasis from sole cash crop production to boost domestic food production.

In the 1980s and 1990s the food crisis in Africa is exacerbating. Its manifestations are (1) Africa's severe nutritional problems compared to other regions of the world (Berg and Whitaker 1986; Hanley 1992B; World Resources 90-91), (2) wide hunger belt and growing malnutrition in Africa (FAO Sept. 1992; World Resources 1990-91; Hanley 1992A; Hanley 1992B; Rotberg 1983; Christensen et al. 1981; UN Statistical Yearbook 1988), and (3) increased food imports by many countries to cover the food gap (UN Statistical Yearbook 1985/1986; Shapouri et al. 1986; Raikes 1991; World Resources 1990-91). Considering the growing magnitude of the food crisis and its expansion to the whole region of sub-Saharan Africa, it seems urgent that policymakers in those countries re-orient development policy to incorporate food production as a priority in the 1990s. If such effort is not done, there is a great risk of severe food shortages and food dependency in the region for the 1990s. The economic decline in the region doesn't seem to indicate that the economies will be able to afford even the cheap foodstuffs from Most Developed Countries (MDCs). 


\section{IMPORTANCE OF FOOD PRODUCTION IN ECONOMIC DEVELOPMENT}

Food production has been advocated by many scholars of Development Economics and Dependency School as an important and critical step in economic development of a country. Rostow's (1990) linear stage theory of economic development suggests development of the food production sector as a prerequisite for industrial take-off. The agriculture sector must be sufficiently developed to provide support for the growing industrial sector. Particularly, the price of food must be made cheap to support industrial workers. In addition, with the development of the food production sector and its mechanization, surplus labour from agriculture sector will flow in the manufacturing sector.

In a comparative study of agriculture of many developing countries since 1935, Colin Clark (Rostow 1990) attacks the wide view in MDCs that agriculture is no longer a key priority in economic development because of its small share of GDP and work force. As Rostow, he supports that improvements in agriculture productivity are necessary conditions for industrial development.

Another pioneer of Development Economics theory, Arthur Lewis (Rostow 1990), known for his two major concepts in economic development (the "anatomy of growth with unlimited supply of labor," and "the fundamental role of increased agricultural productivity in the process of industrialization") recognizes the critical position of agriculture in the process of industrialization.

Carl Eicher and Lawrence Witt (1964) have recognized an important role for development of the food production base in economic development. They recognize that successive steps of the Rostow model are no longer rigidly applicable to economic development. That is, economic development need not be launched by either agriculture or industrial sector alone. Rather, each economy contains both components. However, they suggest a wide agreement by many economic historians that no country in experience has 
fully developed without a rise in agriculture productivity preceding or accompanying industrial development.

As Carl Eicher and Lawrence Witt, W. H. Nicholls (Eicher and Witt 1964) has recognized the dominant place of agriculture in the economic development of developing countries. He has suggested that development requires the migration of vast number of people from the rural agricultural sector to manufacturing and service sectors in the cities. In the investigation of the relationship between agriculture development and industrial development, Nicholls found that agriculture progress is fundamentally a prerequisite for industrial development as is the case in a closed economy. He agrees with the linear models that the prerequisite of industrial development is the achievement of the rate of increase in agricultural productivity that exceeds the concurrent rate in the rate of demand for food. Therefore, the rising agricultural productivity supports and sustains industrial development in two important ways. First, labour force is released from agriculture to industry while meeting the food needs. Second, as a rise in agriculture productivity raises agricultural incomes, it increases the rural purchasing power needed to purchase industrial goods and rural savings that may then be mobilized to finance industrial development. Therefore, it enables agriculture to produce foods at prices that are profitable for industry workers to buy and save to buy industrial products.

Johnston O'Brien (Gladwin 1991) finds that higher food production is critical to achieving structural transformation of the economy from agriculture to manufacturing.

The neo-Marxists and Dependency School theorists such as Samir Amin $(1976 ; 1990)$ suggested that development must satisfy the basic needs of the people. Amin particularly advocates an inward-oriented development that satisfies the needs of the people in African countries. Going against linear stage models, he considers development as a circular process centered on basic needs. Therefore, it can start and expand from any basic need to 
reach the other sectors. Food production falls in this category as a basic needs policy that must be given priority for inward-oriented development.

\section{FOOD PRODUCTION AND THE REALM OF POLITICS}

The issue of food production can be linked to the politics of a country in different ways: world political economy, national economic development (historical and current policies), welfare policies, allocation policies, governance and political institutions that provide a framework for these policies. Each of these aspects is considered in this thesis.

First, the world political economy provides a framework on which political and economic forces affect food production in sub-Saharan African countries. Here, a Dependency approach (Amin 1973; Davidson 1989) explains that the structural setting of sub-Saharan economies as cash crop producers (outward-oriented) does not favor food production to benefit local needs.

The Core as dominant force in the world political economy, the North seriously influences economies politics in the South (Frank 1979; Amin 1985). For example, Gladwin (1991) accuses Structural Adjustment Programs of forcing governments to withdraw subsidies to rural farmers, particularly women. Also, the agricultural trade policies of the EEC (Common Agriculture Policy -- CAP, and Lome Convention agreements) and the USA flood Third World markets with foodstuffs which affect the way policy makers in those countries look at the need for domestic self-sufficiency in food (Raikes 1991). Farmers of the North are satisfied while those of the South and selfsufficiency are sacrificed.

The combination of external interests (MNCs) and those of the local bourgeoisie (elite) often determines the tone of government economic policy (Wambalaba 1985) in African countries. External economic forces have often combined with internal bourgeoisie (Ake 
1978) to thwart politics and economic policy to outward needs rather than those basic needs of people inside countries (Amin 1985). Therefore, aid and development assistance have failed to emphasize food production enhancement in those countries. Rather they have emphasized cash crop production to serve the consumers of the North.

Political forces in the North have often influenced governments of the South (in need to support unpopular regimes) to divert large sums of money to buy weapons, which ends supporting the weapon industries and workers of the North. Also national revenues and loan money have been often misused in building palaces and garnishing foreign bank accounts of government leaders, rather than investing in food production as a basic needs. Food production enters in the realm of economic development which itself is linked to political economy and area of comparative politics. In the domestic political economy, the middle class in the cities force governments to provide cheap foods and imported tastes. Therefore, food imports are and easy solution for political elites to avert middle class revolt in the cities. Furthermore, the centralized nature of many economies in sub-Saharan Africa make them very vulnerable to negative influences of politics.

Second, colonization set up a serious precedent in the economic development of many countries in sub-Saharan Africa. The colonial agricultural system of most sub-Saharan African countries, such as Nigeria, Kenya, Cameroon, Zimbabwe, Kenya concentrated on producing cash crops for the consumption of metropolises (Amin 1973; Berman 1990; Davidson 1989). The case of Kenya reveals that food production was consistently neglected by government policy during the colonial period in the favor of cash crop production for exports. Many governments after independence inherited this structural setting and have not succeed in making a structural transformation of the economies (Raikes 1991; Shapouri et al. 1981; Maletnlema 1991).

Third, welfare policies of the government come to play to determine what are the most important needs of populations. In a parochial system with less developed participatory 
institutions, elite policy often fails to determine what needs are vital to the populations. For example, in Kenya, welfare policies have often focused on providing infrastructure for education and health and have neglected the domestic food production base or left it to subsistence production.

Fourth, allocation policies place the government as a regulator of economic activity. In the case of food production and agriculture in general, examples of the USA and EEC suggest that the government provides loans, grants, and subsidies to food farmers to protect the food production sector. One would have expected similar allocation of resources to rural food farmers in sub-Saharan countries. However, the case of Kenya suggests that the government allocates these resources almost exclusively to cash crop farmers and men particularly. Small scale food crop farmers and the majority women are denied these resources (Gladwin 1991). Another flaw in allocation is the waste of capital resources often invested in capital intensive projects, infrastructure, beautiful palaces, private pockets of leaders, and military expenditures. ${ }^{1}$ These scarce resources could be better allocated to boost private food production.

Finally, governance and political institutions are another area of politics that retards economic development in the Third World (Rostow 1990) and the food production sector in sub-Saharan Africa in particular. ${ }^{2}$ With an undemocratic style of governance in the hands of the elite and the absence of political institutions to aggregate the needs and volitions of food farmers, there is no institutional framework for the latter to express their

\footnotetext{
${ }^{1}$ See TABLE XXX in APPENDIX A; Kenya, Military Expenses as a Percentage of GNP. This table shows that military spending took an average 9.1 percent of total government expenditures.

${ }^{2}$ Gunner Myrdal (Rostow 1990) accused the lack of mature political institutions and the overwhelming government control of economic activity of retarding economic development in Third World countries of Africa. Latin America and Asia. Particularly the parochial, undemocratic, and less developed political institutions did not allow full participation, expression, and aggregation of the interests of the citizens.

Mature political institutions and institutions of governance are crucial to open opportunities not only for participation, but also for access to economic resources. In many African countries, political elites have often dominated every aspect of the national agenda and have hindered political participation and access to economic resources.
} 
needs for support in the food production sector. For example, Women have almost no voice to claim credits, ownership of the land, and other resources that they need for food production.

With more participatory institutions that allow people to express their needs, there is good chance that food production farmers would express a need for government policy allocation of resources to this sector. Conversely, most policy decisions are done at the discretion of elites including the allocation of development resources, casting out farmer from the process (Raikes 1991; Amara and Founou-Tchuigoua 1990). The reasons discussed above will be used in CHAPTER II and CHAPTER III to explain how politics have limited the allocation of resources to food production at scale in Kenya, and have hindered consideration of this sector in comprehensive development policies of the country.

\section{FOOD PRODUCTION AND COMPARATIVE POLITICS}

The issue of food production can be placed in the realm of Comparative Politics as a discipline under the Basic Needs Approach (BNA) to development which emerged in the mid-1970s (Lisk, 1985). ${ }^{3}$ Food production should be sustained in quantity and quality produced so that food availability and quality are met as primary needs to sustain human life.

Comparative Politics as suggested by R.A. Chilcote (1990) deals with comparative investigation of all governmental and non-governmental forms of political activity. Immediately after W.W.II the attention of theorists of Comparative Politics was turned on issues of economic and political development of former European colonies in Latin America, Africa and Asia (So 1990).

${ }^{3}$ Franklyn Lisk suggests that planning for basic needs requires popular participation in the decision making process, both politically and economically. The basic needs approach (BNA) to development emerged in the mid-1970s. It places popular participation as an important prerequisite to attain sustained economic growth and social progress. As such it should be placed as a development goal . 
Modernization theory emerged in the late 1950s and early 1960s as the predominant view for development predicated by developed nations to the emerging nations. Modernization is a multidisciplinary approach to examine Third World development based on Western models. ${ }^{4}$ This School of thought encourages Third World nations to follow the example of Western nations in their political and economic development. That is, to adopt pluralistic and democratic political institutions as well as institutions of governance, to engage in free market economy, and to follow the linear stage models of economic development. The most known models are the European evolutionary model, Rostow's phased economic modernization process, and democratization through liberal pluralism. Other schools of thought to approach development in the Third World emerged starting from the early 1960s: the Dependency School in the 1960s as a critique of both the modernization model for LDCs and Orthodox Marxism in Latin America 5, the underdevelopment theory, and the concept of neo-colonialism.

4 (So 1990). Modernization theory encompasses political, economic, and socio-cultural aspects. Therefore, it draws from many disciplines including economics, political theory, sociology, psychology and others.

${ }^{5}$ The Dependency School was also a critique of the orthodox Marxism in Latin America. Marxist influence reached Latin America only tardily and remotely in the 1870 s, introduced with a stream of European immigrant refugees from the French Commune, the Italian Risorginento, and the republican struggles in Spain (Aguilar 1978). They brought new social consciousness not only with an impetus towards rebellion and self-organization, but also a strong tendency towards anarchism as a doctrine.

Orthodox Marxism was characterized by (1) anarchism by rebellion that did not provide any economic independence nor development, (2) justification of struggle on Cold War lines rather than on class struggle as classical Marxism supports, (3) tendency towards an anarchical peasant-proletariat government without any leadership. Orthodox Marxism was widespread between 1928 and 1935 . It was accompanied by increased revolutionary radicalism of Communist parties against capitalism and Trotkyst Socialism throughout Latin America (Cuba, Argentina, Brazil, Chile, Mexico).

Orthodox Marxism was criticized in the 1960s for its lack of productivity and ineffectiveness to achieve a socialist revolution. Carlos Salazar Montejo (Aguilar 1978) critiques Orthodox Marxism for drifting away from organized struggle of the proletariat against the exploitative bourgeoisie (classical Marxism) to focus solely on Cold War motives under control of the Soviet Union. Revolutionary anarchism in Latin America, for example in Cuba with the Castro regime, has claimed to fight US imperialism. Yet it has fallen under Soviet imperialism and increased rebellion in the cities with no prospect of any successful socialist revolution. The Cuban economy has not improved, but declined dramatically instead. Therefore, Orthodox Marxism has placed Latin American countries on servitude under Stalinism and created dependency on the Soviet Union rather that independence that it intended to obtain. Montejo also accused the Communist parties in Latin America for having inherited corrupt hierarchies from Stalinist Moscow and have established a reputation for servility, impudence, and political irresponsibility. 
The Dependency School (ECLA in the early 1960s; Bodenheimer in 1970; Dos Santos 1973, Cardoso and Faletto 1965 (1971)) came to existence as a sharp critique of the modernization model after the failure of Western models to solve growing problems in many LDCs of Latin America and Africa: unemployment, inflation, currency devaluation, declining terms of trade and other economic problems.

The Dependency School states that capitalism keeps the Third World in a structural dependency situation on the Core composed of industrialized countries (Cardoso and Faletto 1971). Therefore, the only way out is through autonomous peripheral capitalism with centralized state control and the acquisition of industrialization (ECLA, Raúl Prebish in (Rostow 1990)). To go further, eliminate the disparity of incomes in the periphery caused by industrialization. Cardoso and Faletto propose implement of socialism is the best way to achieve these objectives. Thus the Dependency School calls for development based on industrialization with Import Substitution Industries (ISI) and the "delinking" from Western world as advocated by Prebish moreover reformulated by Samir Amin (Amin 1985).

Amin recognizes the expansion of world capitalism. However, he acknowledges that the world capitalist system based on liberal utopia has failed to produce growth and benefits for all. Rather it has favored the accumulation of wealth and power in the North and caused progressive marginalization of the South, particularly Africa. Amin suggests that the only way for Third World countries to escape the structural constraints imposed on them by the world capitalist economic system is to "delink" if they ever hope to raise living standards of their populations. He does not call, however, for complete self-sufficiency or economic autarky as the ECLA has supported. Rather he suggests that each country submit its external economic relations to domestic development priorities, i.e., to limit the effects of external economic forces on internal choices. He contends the basing of development 
only on competitiveness as suggested by the liberal doctrine. Rather it implies a sustained and constant improvement of productivity in all possible fields from a given starting point and action to ensure the participation of all and the equal distribution of the returns. Amin calls for "reciprocal adjustment" rather than unilateral adjustment of the weak to the strong, also rejection of bourgeois subordination that reproduces intolerable economic situation for the South. He concluded that achievement of such an aim requires broad popular coalition to control the state and protect it from external forces and their allied internal forces.

In the late 1960s another concept, 'underdevelopment' was introduced by Gundar Frank (1967; 1969; 1979). This school of thought develops the idea of metropolis-satellite exploitation. On the world capitalist system, Frank suggests that modernization favors development of the metropolis and under-develops the satellites. The metropolis continually exploits the resources of the satellites in a way that destroys traditional customs, skills, trading systems, and communities. A consequence is a dependency of periphery countries on international market mechanisms in which they are not players. Samir Amin (1976) developed the concept of underdevelopment further to apply it to the dualistic economies in LDCs: a developed economy at the urban centers that underdevelops and exploits the rural areas. He called this relationship "internal colonialism." Amin has particularly applied this concept to former colonies in sub-Saharan Africa.

Amin continued his work to criticize outward-oriented development policies as a continuation of neocolonialism (Amin 1973) and as a dependency trap that thwarts any possibility of real development in those countries that meet the basic needs of the people. In Maldevelopment (Amin 1990) Amin criticizes the failure of development in the Third World. particularly Africa. He suggests that the major reason has been an outwarddevelopment trend that does not target the needs of domestic economies. As in Delinking 
(Amin 1985) he suggests breaking the dependency bond by embracing inward-oriented development strategies sustained by popular political movements to catalyze national efforts and to provide a better resistance to external bourgeois forces.

In the 1980s and 1990s, however, continuing catastrophic decline of economies in the Third World (Africa particularly), growth of abject poverty, communal violence, the denial of basic needs to more than $20 \%$ of the world's population living in those areas (Korten 1990; Cheru 1989), and the failure of development in the Third World (Amin 1990), seem to question the validity and applicability of Western prescriptions particularly the Structural Adjustment Programs (SAP) imposed by the IMF. These trends seem to call for a reorientation of these programs (Berg and Whitaker 1986). Therefore, new approaches by scholars in the Third World come about to emphasize sustainable and inward-looking development strategies for LDCs (Korten 1990; Cheru 1989; Amin 1985). Sustainable development strategies are those which emphasize on satisfying the basic human needs of food, health. and education. This approach to development draws from the Basic Needs Approach (BNA). In other words this trend calls for economic development strategies that are people-oriented in a way that is sustainable to their cultural and physical environment. Food production falls in this category as a major basic need to prioritize.

\section{SUB-SAHARAN AFRICAN CRISIS}

Sub-Saharan Africa, one notable example where development solutions seem not to hold, is plagued in the 1980s and 1990s with many difficult problems to solve (Cheru 1989: African Recovery 1992, vol. 6): growing debt burden and rampant poverty of the masses ${ }^{6}$, denial of human rights (Ntanda 1993), communal violence ${ }^{7}$, high population 
growth (see Figure 6) ${ }^{8}$, growing hunger (see Figure 3) and malnutrition (see Figure 5) in the 1980 s (Shapouri et al., 1986) with a prospect of severe food shortages in the 1990s (FAO Sept. 1992; World Resources 1990-91; Hanley 1992A; Hanley 1992B). 9 Addressing the issue of debt, many impoverished sub-Saharan African countries are locked in the debt cycle. Although the debt is smaller compared to Latin America $(\$ 182.284$ billion versus $\$ 225.962$ billion for South America in 1987) 10 at issue is that these countries do not have means to pay back the debt. This locks them into negative transfers and debt crisis (Berg and Whitaker 1986). Unemployment adds to the debt burden and

\footnotetext{
6 SRI CIS 1991, R 8750-5, 1991 World Population Projections to 2025 by region and country. This report shows a GNP per capita in Africa of $\$ 610 /$ year against $\$ 2,380$ for Asia as a whole, and $\$ 1,980$ for Latin America.

World Debt Tables, the World Bank 1989-90 shows the sub-Saharan Africa region with an outstanding debt of $\$ 140$ billion for total EDT and $\$ 40$ billion from private sources in 1989 . The report reveals a principal debt service of $\$ 8$ billion/year on average with interests of $\$ 4$ billion/year in average, and debt service ratio (INT/XGS)of 25\% in average per year between 1979 and 1989. The EDT/GNP ratio of almost 120 in 1989.
} Rwanda.

7 For example, recent civil wars in Somalia, Sudan, Liberia, Mozambique, Angola, Burundi, and

${ }^{8}$ See U.S DCESA. (1991). This report shows an annual average population growth rate of $3.0 \%$ in Africa compared to 2.1 in Latin America and 2.0 in Asia (excluding China).

See also (Hanley 1992A). The population of sub-Sahara Africa is estimated at 495 million in 1990 and to be 668 million by year 2000 and 1.2 billion by year 2025 , which is a growth rate of about $3.4 \%$ per year.

9 FAO (FAO Sept. 1992, 9) indicated a total of 9,795 thousand tons of cereal import requirement, 4,962 anticipated commercial cereal imports, 4,833 total food aid requirements with 2,470 out of emergency. All these imports are needed to offset the deficit with the only 21,825 thousand tons produced domestically.

The United Nations Statistical Index 1981 (World Summary) shows that Africa lags behind Latin America and Asia in total per capita food production since 1970s. Also the per capita food production of Africa has severely declined (101 in 1970 to 89 in 1980) as opposed to Latin America and Asia whose indexes have increased or remained constant.

See also (World Resources 1990-91, 87). Table 6.2 shows that Africa had the highest share of malnourished population in the world from 1969 to 1985 (32\% of population in 1969-70 and 32\% in 198385.)

FAO predicts a 200-million tons food gap in sub-Sahara Africa by year 2020 (Hanley 1992A).

World Bank report (Hanley 1992B) on nutrition shows that Africa lags behind in the daily calorie supply per person in 1989: 2,122 for Africa versus 2,617 for East Asia/Pacific, 3,433 for Europe, and 3,671 for the United States.

\section{See World Resources 90-91 SRI R9455, p.248}


flawed economic policies to cause alarming poverty for the common human in the region. With the growing economic desperation of thousands, the crisis of governance in many countries, communal violence and denial of human rights are visible almost everywhere (Zaire, Chad, Cameroon, Liberia, Sierra Leone, Somalia, Sudan, Ethiopia, Mozambique, Burundi, Rwanda, etc.) Total anarchy has arisen in some cases causing the death of thousands and displacement of millions in cases such as Somalia in 1993 and Rwanda in 1994. The main aspect of interest in this research investigation is that food shortages and malnutrition are on the rise. Fred Sai (Berg and Whitaker 1986, p. 140) suggests that "sub-Saharan Africa is the only region in the Third World that suffered the most of nutritional problems and severe food shortages on a large scale in the 1980s." Furthermore, Hanley's (1992A; 1992B) articles on hunger in Somalia and Ethiopia reveal a hunger belt covering most of sub-Saharan Africa. The same articles show that Africa is the continent with the highest rate of population growth, and the highest hunger and malnutrition population in 1993. Facing all these crises, attention comes to search for strategies to secure at least the vital basic needs to the populations of sub-Saharan Africa.

\section{A SURVEY OF THE KENYAN SITUATION}

Kenya is a country in East Africa. The East Africa Region since the British colonial era is politically defined as a set of three countries: Tanzania the largest, Kenya the second largest. and Uganda the smallest (see Figure 1.b and Figure 2 in APPENDIX B). This region was colonized by Great Britain just before the turn of the 19th century (Duignan and Jackson 1986; Ochieng 1990; Berman 1990). Kenya covers a total area of 582,644 Km², and had a population of 25.2 million in 1991 . With an average annual growth rate of $3.2 \%$ in the early 1990s (one of the highest in the world), the actual population of the country is 
expected to double by the year 2010 and its annual growth will reach 4\%. 11 Population growth in Kenya has been always a problem for land shortage and food supply since the colonial era in Kenya.

Kenya is a middle income country to African standards with an annual GDP at current market prices of US $\$ 8596$ million and a GNP per capita of US $\$ 380.00$ in 1988.12 In 1987 the total external debt of Kenya was $\$ 5.95$ billion with a debt/export ratio of 342.0. Nonetheless its delicate ecological setting (with only $9 \%$ of the total land suitable for good agricultural land), Kenya is an agricultural country. Its economy relies heavily on cash crop agriculture as the single major contributor of GDP (40\% in 1956-63, and roughly 30 $\%$ from 1964 on.) The major export cash crops, ranked in the order of importance, are coffee, tea, pyrethrum, and others (sisal, horticultural products). Its main staple food for domestic consumption is maize, beef and dairy products.

Kenya became independent from Great Britain on December 12, 1963 after almost three quarters of a century of British colonial rule starting from 1895. Jomo Kenyatta, national leader of KANU (Kenya African National Union) and long time nationalist leader, became the first president and built a semi-democratic one-party state. One may suggest that Kenyatta's rule embodied characteristics of authoritarian paternalism, increased state intervention in the economy and Kenyatta's personal rule. At Kenyatta's death in 1978, Daniel Arap Moi at the time Vice President and member of KANU took over. Moi started on a promising tone following closely on policy lines drawn by late Kenyatta. However,

${ }^{11}$ U.S DCESA. (1991). World Population Profile: 1991. U.S. Department of Commerce Economics and Statistics Administration BUREAU OF THE CENSUS.

The US Statistical Research Institute (SRI, CIS R 8750-5: 1991 World Population projections to 2025 by region and country, 1991 annual data sheet.) indicates that in mid-1971 Kenya's population was estimated at 25.2 million, with an annual natural increase of $3.8 \%$, a "Doubling Time" of 18 years as opposed to 90 years average in the developed countries, and a projected population of 63.2 million in year 2025 .

12 See African Socio-Economic Indicators 1988- United Nations-ECOSOC. 
with more state control of power and an attempted coup in 1982, Moi's regime became increasingly corrupt and repressive.

The choice of Kenya as a case study has been guided by its complex and unique colonial experience in black Africa (Ochieng 1990), its particular ecological situation and great reliance on commodity export crop agriculture since the colonial era (Berman 1990), its agrarian crisis starting from the 1980s (Shapouri et al. 1986; FAO 1986-87) and worsening in the 1990s (FAO Sept. 1992; Raikes 1991). Many elements distinguish Kenya's colonial experience from that of Tanzania, Uganda and any other former European colony in black Africa (Berman 1990). First is Kenya's strategic position as the Center of the British East African Protectorate from 1895, and therefore, center of the vital railway road to link the center of the region to the coastal ports. Also because of its unequaled temperate climate in the region and its fertile highlands around Mount Kenya, Kenya offered favorable conditions for settlers' goals for an agriculture-based independent country such as present day Zimbabwe in Southern Africa. Second, differently from other former British possessions, Kenya was ruled directly. A sizable colony of European settlers established themselves in the country. Third, on economic aspect Kenya has experienced a high degree of capitalist penetration in social relations of production not only in settler agriculture, but also in metropolitan/international industrial investment, peasant commodity production, the spread of commodity production, and finally the process of class formation within the indigenous populations. As a result Kenya's economic development by the time of the independence was far ahead that of Tanzania, Uganda and many other countries in black Africa.

This study focuses on the experience of Kenya since the early times of British penetration in the 19th century. However, intention is not to make an economic analysis of the country. Rather, a discussion is conducted on major political and economic characteristics of colonial Kenya as well as major developments in the political economy 
and their implications. Of primary interest for the thesis is food production and supply for domestic needs, and government policies regarding food production. The scope of investigation covers two periods: the colonial period extending from 1895 (beginning of effective British control over Kenya as a Protectorate) to 1963 (date of Kenya's independence from Great Britain), and the post-colonial period extending from 1963 to the 1990s. The post-colonial period is investigated in two sub-periods corresponding to the two presidential regimes of the country since independence: Jomo Kenyatta (the immediate post-independence period, 1963-1978) and Daniel Arap Moi (the period extending from 1979 to the early 1990s). For each period, issues relating to the political economy of the country are investigated and an attempt made to link the current politico-economic characteristics with the colonial experience of the country. Of particular interest is the agrarian crisis of the 1980s and the 1990s in Kenya. An attempt is made (1) to link the roots of the crisis to colonial policies that emphasized expanded commodity production agriculture at the expense of food crop production for domestic markets, and (2) current government policies.

\section{GOALS OF THE THESIS}

This thesis analyses the food crisis in Kenya as a case study in sub-Saharan Africa in the 1980s and 1990s, identifies roots of the problem, and proposes strategies of sustainable development based on self-help in food production for domestic markets and needs. This recommendation calls for a shift of emphasis from cash crop production to accommodate food crop production in economic development policies and practices. The main goal is to devise development strategies centered on developing the agricultural sector to secure 
enough food production and supply ${ }^{13}$ for domestic consumption. This view supports that Kenya, and in extension other sub-Saharan African countries should rely heavily on developing the agricultural sector for food production to experience any meaningful development at all, and to escape a dark future of food shortages. Facing the severe food shortage in the region, a very affordable solution seems for these countries to boost the internal basis of food production for local needs in the short term. It should not be understood that economic development of the region should be focused only on the food production aspect. Although it is a triviality that food is not the only aspect of life, it is, nonetheless trivial that lack of adequate food is a threat to productivity and animal life as a whole. Therefore, securing self-sufficiency in food should be made a priority for subSaharan African countries in the 1990s.

\section{HYPOTHESES}

Many theories in Development Economics ${ }^{14}$ recognize that development of the food production sector of agriculture is a prerequisite for any sound economic development, particularly development of a sustained industrial sector. Based on this premise, my ambitious conclusions on the African food crisis stem from the following reasons:

(1) The economic problems and food shortage in sub-Saharan Africa are

13 The reader should be aware of the distinction made between food production, food supply and food availability. Food production is used throughout the thesis to indicate the quantity of foodstuffs that are harvested or produced domestically. Food supply indicates the quantities of food available in the market as a whole including the food produced domestically and the food imported through aid or loans. Food availability is used to indicate the food that is really available to the consumer in relation with his/her buying power moreover in relation to the capacity of the market and distribution systems to make the food available to the consumer.

14 See Rostow and Colin Clark (Rostow 1990), Carl Eicher, Lawrence Witt, and W.H. Nicholls (Eicher and Witt 1964). Even some scholars of the Neo-Dependency School such as Samir Amin (Amin 1990) call for a sustainable development based on inward-looking strategies that secure the basic needs of the populations. Since food is placed first in the list of primary basic needs, it can be understood that inward-looking development strategies should stress development of the food production sector. 
similar from one country to another, which this research to hypothesize that the origin of the problem is rooted in the colonial legacy that these countries inherited, especially considered that they are still dependent economies,

(2) Colonial and post-colonial agriculture has encouraged production and export of foodstuffs and cash crops at the expense of sustainable food production for local needs,

(3) As a consequence there is a lack of adequate food supply for the fast growing population--and hunger is a crisis in the region. Therefore, there can be no significant development when the people are not adequately fed,

(4) Western policy advisers have tried to solve the problem of bad economies but have concentrated mostly on growth with the GNP/capita indicator and on commodity production to pay the debt; hence they have paid little or no attention to the food production sector,

(5) Some projects proposed by governments and supported by Western donors such as capital extensive agricultural projects (large scale irrigation, for example), drain financial resources and exacerbate the debt,

(6) The modern agricultural techniques are not sustainable because pesticides and chemical products destroy the useful land through,

(7) The overemphasis on the development of the cash crop and industrial sector has caused a big income differential that adds to government neglect and some ill-thought donor policies to give fewer incentives for food production. Therefore, the price of food is high compared to the average income per capita from cash crop production for exports and the industrial sector,

(8) Boosting food production for domestic consumption is a sure way to set a basis for small scale industrialization to support food production.

\section{METHODOLOGY}

The methodology used in this thesis is a comparative analytical model . First, the food crisis is identified as a common problem for many countries in sub-Saharan Africa and its general causes are investigated. Second, Kenya is used as a model to confirm the hypothesis that roots of the crisis are strongly linked to colonial setting of these economies 
as cash crop and raw material producers. Also, government policy neglect of the food production sector is matched in the Kenya case.

An in-depth review of (1) Kenya's colonial political economy from 1895 to 1963, (2) the current economic situation, and (3) food production, supply and distribution, is conducted. The causes of Kenya's food problem are identified and analyzed by trying to find a link between current economic characteristics of the country (including the food production sector) and those of the colonial period. This way of proceeding has been inspired by the fact that Kenya and many other economies of sub-Saharan Africa have remained agricultural and resource producers as they were during the colonial period. Many of these economies emphasize cash crop production for exports as the main source of national revenues (Davidson 1989; Amin 1973).

Kenya was chosen because of its ranking by FAO among the countries with prospective food shortages in the 1990s (see Figure 3). A second reason for the choice of Kenya is its 'rich' colonial experience with Great Britain, its dependence on commodity cash crop exports, and its economic and hunger crisis starting from the 1980s (Shapouri et al. 1986) and worsening in the 1990s (FAO Sept. 1992). Other criteria include the fact that Kenya has one of the fastest growing populations in the world (3\% to $4 \%$ since the 1950 s). Furthermore, Kenya heavily relies on its agriculture for exports and food supply on an unfavorable ecological setting that provides only $9 \%$ good agricultural land out of the total land area.

Strategies proposed for a development centered on food production in the short term are applied to Kenya. An evaluation of the strategies proposed is conducted considering their capability to overcome existing domestic (flawed government policies, debt, poverty, level of development, ecological setting, etc.) and international barriers (exploitation, imbalance of terms of trade, capitalist imperialism, etc.) The strategies are designed to be as broad as possible to answer food problems common to the sub-Saharan region as a whole. 
The thesis is divided into six chapters. CHAPTER II is an investigation of colonial Kenya from the beginning of British penetration in 1887 to independence in 1963 . The political economy is analyzed and government policies are examined with special attention on the emerging permanent characteristics of the political economy and the food production sector. In this chapter an attempt is made to find hints of food problems stemming from government policies during this period. The impact of politics on food production in Kenya during this period is discussed.

CHAPTER III is a study of post-independence Kenya from 1963 to present. The major aspects of investigation are government policies and food production situation. An attempt is made to find colonial characteristics in the modern political economy of the country. The discussion tries to demonstrate that the food crisis in the 1990s is not only due to a very high population growth rate as contended in general by Western economic analysts, but most of all is grounded in the government policies that neglect food production. This argument is supported by the fact that Kenya has turned from selfsufficiency in food production before and at the onset of the colonial period and in the 1960 s to a net importer of food in the 1980 s and 1990s. This characteristic, it is demonstrated has originated from the setting of colonial agriculture whose development policies completely neglected African agriculture. Even after liberalization in the 1950s with the Swynnerton Plan (Berman 1990; Heyer et al. 1976; Shiroya 1968; Duignan and Jackson 1986) government policies stressed the growing of cash crops for exports at the neglect of food production for local needs. Therefore, it comes to mind as a better strategy to attack the problem at the root rather than focusing on current adverse conditions of the world market alone.

Although neocolonialism still affects former colonies of Africa (economic dependency, exploitation of natural resources, political influence in domestic and international affairs), it 
is not correct, however, to blame the colonial experience alone on the current situation some thirty years after independence. It is important to recognize that many dependent economies of sub-Saharan Africa including Kenya have failed to restructure their economies by removing the colonial characteristics. Therefore, the impact of local politics on food production is assessed and discussed at the end of the chapter.

CHAPTER IV starts on an assessment of sub-Saharan Africa's food crisis from the 1970s to the 1990s. Roots of the problem are investigated which may link the crisis to colonial setup of the economies of the region. The chapter continues with an investigation of solutions that have been proposed to address the food crisis in sub-Saharan Africa. The chapter finds reasons that support development of food production sector based on Development Economics theories and the experience of agriculture-rich Western countries. A case for policies encouraging food production is made at the conclusion of the chapter.

CHAPTER V presents conceptual solutions aimed at increasing food production in subSaharan Africa. Specific problems such as the reorganization of production, distribution and marketing of foodstuffs, decentralization with development of rural economies around food production and agribusiness industry, the reorganization of rural communities around food production business are targeted. The first three issues (production level, distribution, and marketing of foodstuffs) were found responsible for the inefficiency of the Kenya's food production sector to meet the demands of its growing population. These problems were also found common to other African countries in sub-Saharan Africa, Cameroon as an example (Boyer and Davis 1990). Therefore, the thesis builds from the case of Kenya primarily (and Cameroon to some extent) to conceptualize solutions to develop the food production sector in countries of the region. The chapter concludes with an assessment of unanswered questions for the proposed strategies to find a fertile ground in a prospective implementation by policy makers. 
The last chapter opens new horizons for the strategies, namely (1) the long term correction of the food gap and possible increase in domestic savings, (2) regional economic integration with trade of foodstuffs within sub-Saharan Africa, and (3) the creation of small scale entrepreneurship industry in the agribusiness sector that will be domestic-owned, to satisfy the needs of the growing food production sector of the economies. 


\section{CHAPTER II}

\section{COLONIAL KENYA (1895 - 1963): POLITICAL ECONOMY FOOD PRODUCTION AND SUPPLY}

\section{INTRODUCTION}

From the time the structures of the colonial administration and its economic foundations were established in the first decade of the 20th century, the political economy of Kenya inherited four major characteristics (Berman 1990). The first was a dialectic of the colonial state itself caught in the process of reconciling conflicting interests and at the same time maintaining its autonomy. On one hand the state had to legitimize and protect settler production by control and exploitation of African labour. On the other side its efforts were to maintain autonomy as a neutral arbiter between settler and African interests. However, the state acted in the interests of the settlers although it claimed to act in the best interests of African as its paternalistic ideology presumed. As a consequence Africans distrusted the colonial administration and their struggle intensified against the settlers who had confiscated their land.

The second characteristic was the high level of state control and intervention in the economy. The various studies covered in this research indicate that state policies intended to keep the agriculture-based economy afloat by providing settler production with coerced or cheap African labour to achieve surplus (1920's). 1 The state sometimes encouraged

1 Basil Davidson (1989) suggests three ways in which the few Europeans in the colonial state controlled the many Africans: (1) physical coercion by military force that wasted many lives and faced increased resistance of the colonized, (2) high taxation that forced Africans to labour for settlers and the colonial government to pay taxes, and (3) the forced labour policies whether from coercion or taxation 
controlled peasant production to back up the declining settler production during times of economic downturn such as the Great Depression. The third characteristic was the nature of colonial Kenya's economy as a cash crop production enclave for exports to England. The fourth characteristic relates to government reforms of 1954. Since the Swynnerton Plan, government policies encouraged a significant level of foreign investment in Kenya's industrial sector by multinational corporations. This policy was continued by the postindependence governments of Kenya and explains the high level state control and intervention in the economy of the country.

All these characteristics went hand in hand with the contradictions of Kenya's political economy. First, the authoritarian attitude of the state towards Africans contradicted its paternalistic ideology to act in their best interest. Second, the struggle over land confiscation from Africans by the settlers and the scarcity of arable land in the African reserve areas intensified. Third, a class split emerged among Africans in the rural areas: an African petty bourgeoisie of wealthy peasants and a class of landless peasants. These contradictions intensified nationalist and political organization of Africans that culminated in the Mau Mau uprising of 1952. For the most, policies of the colonial state before 1952 dispossessed or exploited Africans to the benefit of the settlers. These policies changed after the Mau Mau insurrection in an attempt of the colonial state to keep a Europeandominated state by co-opting Africans into a multiracial society. At the exception of the paternalistic policies of the Provincial Administration, ${ }^{2}$ policies of the colonial state almost uniquely emphasized cash crop production. 3

removed a great number of village men from rural areas and largely disturbed the stability and peace in rural areas.

2 These policies encouraged food production for self-sufficiency of the household in African reserves only to avoid the breakdown of African societies.

3 See also Basil Davidson (1989). 
Food production by indigenous Africans was sufficient during this period of Kenyan history and was carried with traditional methods of household production, mainly in rural areas (Ochieng 1990; Duignan and Jackson 1986). However, the policies of the state and the nature of the economy that put too much emphasis on cash crop production for exports progressively eroded Kenya's self-sufficiency in food production (Duignan and Jackson 1986; Berman 1990; Davidson 1989). The problem worsened exponentially with the country's high population growth as will be analyzed for the post-colonial period.

Major developments in Kenya's political economy serve as a guide to the discussion of the country's colonial period. The first period is the beginning of Kenya as a colony (1895-1914) and the underlying fundamental characteristics of the political economy of the country. The second development took place during the 1920s and 1930s as a response of the colonial government to international economic depressions. The policies of the state tended to maintain the economy afloat and settler domination of production.

The period after the war (1945-1952) was characterized by a surge and intensification of African nationalist movements in Kenya as well as a decline of settler production and influence in the colonial state. African nationalist movements started to expand statewide at the example of the transformation of KAU (Kenya African Union) into KANU (Kenya African Nationalist Union) in 1944. Also, a growing class struggle originating from class struggle among Africans and the issue of land confiscation triggered the Mau Mau rebellion in 1952 and the subsequent state of emergency in the colony. The third development came after 1952 with government reforms initiated under pressures by Eliud Mathu 4 and the subsequent reforms of the 1954 Swynnerton Plan (Berman 1990; Duignan and Jackson 1986) of land reform and cash crop liberalization for Africans. These reforms increased the size and gap between the class of wealthy African peasants and the landless peasants.

\footnotetext{
4 Eliud Mathu was the first elected African to the Legislative Council in 1944 (Myrick 1975).
} 
Also, the improvement in labour wages and work conditions in the cities following the Report of the Carpenter Commission on African Wages, accelerated with new influx of foreign investment increased. The size of the urban proletariat increased and this gave an opportunity to new petty traders and businessmen among Africans. This period witnessed an expansion of nationalist movements and the increase of African representation in the central political organs of the colonial state such as the Legislative Council and lower state bureaucracy.

The imprisonment of political leaders after the Mau Mau rebellion in 1952 (including Jomo Kenyatta) caused increased tensions and nationalist pressures. These pressures defeated the efforts of colonial officials and settlers to transform Kenya into a multiracial state dominated by Europeans. The power of the colonial state and the settlers dwindled as the African elite and wealthy class directly dealt with metropolitan capital and officials. The decline of the British position as a world economic and military power after W.W.II, and the involvement in the Suez Canal crisis of 1956 made it difficult for Great Britain to maintain colonial rule in many colonies in Africa (Berman 1990). Also after W.W.II, United States policy encouraged freedom fight of the colonized people against colonization around the world. Particularly the United States pushed the United Nations to force colonial powers to grant independence to their colonies and trustee territories (Davidson 1989). Therefore, beginning of 1959 , British metropolitan authorities entered a process of progressive road toward the independence of Kenya.

\section{THE BEGINNING OF KENYA AS A COLONY: THE MOTIVES}

As Ochieng's study suggests, Kenya has the most complex colonial history among all British colonies in Black Africa. Its colonial experience is diverse. Early trade contacts (ivory, rhinoceros horns, and tortoise shells) started with the Roman Empire through the 
intermediary of Arabs. Portuguese penetration by the 16th century began with control of trade in the whole Indian Ocean, and their conquest of coastal towns including Sofala, Kilwa, Mombassa, Zanzibar and Pemba in the early 1500s. After two centuries of ravages of the slave trade carried by the Portuguese, the Omani Arabs colonized the region and continued the slave trade as well. Finally, British colonization started with early commercial interests in 1887 that opened the door for colonial rule. British colonial rule lasted until Kenya's independence in 1963.

A better understanding of the political economy of colonial Kenya requires a grasp of the motives of British penetration in the country, and the foundations of British colonial rule in the country before W.W.I. These aspects provide a ground for understanding key characteristics of the colonial state and its policies in Kenya as well as the characteristics of the Kenyan economy starting from this period.

P.O. Ndege (Ochieng 1990) and Berman's study both traced the beginning of Kenya as a colony before W.W.I. The earliest commercial interests of Britain in Kenya started in 1887, represented by William Mackinnon, a businessman who formed the East African Association to trade with the Kenyan mainland that was at the time ruled by the Sultan of Zanzibar. In 1888, the caravans of the British East Africa Company (IBEAC) penetrated from the coast with primary interests in the commerce of ivory. However, IBEAC became bankrupt and could no longer represent the British imperialistic interests in the area as a private company. Of particular importance was (1) the desire of British officials to maintain British influence around East Africa to compete with other colonial powers (the Germans and Italians), and (2) the construction of a vital railroad to link the coast to the interior for exports. Therefore, in 1895 the British Government established control over Kenya as a Protectorate. Because of its strategic position to the coast, its temperate climate and rich land around the Rift Valley, the colony suited for European settlement, agriculture and ranching. Kenya became the Center of the British East African Protectorate in 1895 
with its capital Nairobi as the center of the railroad. Until 1900, the Kenyan Protectorate remained under the British consul-general who resided in Zanzibar. Then there was the establishment of a Protectorate Commissioner stationed in Nairobi.

The role of the colonial state was to exercise control over the colony to supervise production of agricultural commodities (coffee, tea, wattle, wheat, pyrethrum and maize) for export to Great Britain. The necessary precondition for the establishment of any forms of production and self-sufficiency of the colonial state required stable and effective control over African populations. Therefore, the British (settlers particularly) used military force to subdue the Maasai,5 Kikuyu and the Luo. However, maintenance of order through military power was costly for the new colonial state. Therefore, the strategy of the colonial state was to replace military power by civilian power, i.e., to obtain the consent of Africans. They used uniformed police, hut taxes, and a system of passes for Africans. Collaborators were rewarded with medical advantages and limited education while the recalcitrant were expropriated. The colonial officials used the African chiefs and the headsmen to secure the collaboration of their tribesmen.

By 1902, the Protectorate's first Commissioner Sir Charles Eliot started a program that encouraged more European settlers in the colony. The policy was to create an agriculturebased economy dominated by settlers to finance the construction of the railway and to be the base for commodity exports to England. In 1905, vast lands in the Maasai, Kikuyu and Luo areas in the Rift Valley were confiscated and given to the settlers to constitute the "White Highlands" rich in fertile soil, moderate climate and grazing land. A regulation was subsequently passed to forbid the transfer of "White Highlands" to ownership by Africans.

${ }^{5}$ In the 19 th Century, the Maasai had dominated the area. At the beginning of the 20th Century, their domination was being replaced by that of the Kikuyu and the Luo. 
The settler economy benefited of the surplus that coerced African labour offered and financing of infrastructure from taxes 6 imposed on Africans. Settler agriculture surplus depended solely on the provision of African forced labour because of lack of machinery and improved agricultural expertise. Therefore, British settlers pressured the state to provide free labour for their farms. The colonial state responded by using African chiefs as collaborators to provide unpaid labour from their tribesmen. In the first decade of the 20th century, the agriculture-based economy of colonial Kenya was flourishing from settler surplus. By 1913, the economy was agricultural commodity export and dominated by settler production, a characteristic that will be maintained until the early 1940s.

In the second decade of the 20th century, the political economy of colonial Kenya was laid down: an authoritarian and coercive state apparatus, and a cash crop economy dominated by the settlers while the Indians traded imported commodities in the rural areas. The state apparatus was a prefectural system with a Central Administration represented by a Secretariat and a Legislative Council in Nairobi, and Provincial Administration composed of field administrators (Provincial and District Commissioners) in the rural districts with their networks of collaborators (African chiefs and headsmen). Three main characteristics of the political economy of the colonial state began to emerge in Kenya. First, the struggle over land confiscation from Africans and their resentment against colonial authority increased because of the unfair methods of the colonial state: forced labour, taxes and coercion. Second, the commodity export agriculture was dominated by settlers as owners of estate and farms while the Indians were petty traders in the rural areas. Africans were denied access to economic production. Third, the colonial state found itself in a delicate contradictory situation. At one level the legitimating of surplus accumulation by the settlers required the control of the African peasant production. At the second level the colonial state

\footnotetext{
${ }^{6}$ Between year 1904 and 1905 , Africans paid $29 \%$ of the hut tax revenues and by 1910 they paid up to $40 \%$ of total state revenues in taxes and import duties. The state used hut tax revenues to finance building roads and other infrastructures.
} 
was caught in a dilemma to maintain a neutral position between the expropriated Africans and the influential settlers. The state found itself mostly favoring settlers at the expense of African interests.

As Berman suggests, five contradictions characterized the colonial state in Kenya before W.W.I: (1) the dialectic ties of the colonial state to settlers and the Africans as local classes of producers with clashing interests often dominated by settler influence over the government, (2) the internal contradictions of the political economy, notably the conflict between the Central Administration and the Provincial Administration created a dual administration system, (3) the colonial state acted on behalf of settler interests although it claimed neutrality and commitment to protect African interests, (4) the growth of segregationist ideas to limit contacts between African and settler areas, and (5) the expansion and scope of state intervention in the political economy of the colony. As a result of these contradictions the colonial state's control shaped the process of class formation in the colony. Also, the state apparatus increased before W.W.I. The structure of the colonial state did not significantly change after the war. However, the size of its apparatus and its policies changed with economic depression and the rise of African political consciousness in the 1920 s.

\section{THE COLONIAL STATE: POLICIES, CONFLICTS AND CONTRADICTIONS}

The colonial state had a major policy of protecting the cash crop economy dominated by the settlers. The revenues from exports helped the state to make construction projects such as the railway and other infrastructures such as roads, hospitals, and schools. The state used control. coercion and paternalism over the Africans to the benefit of settler interests. Investigation of different colonial periods suggests that the policies of the colonial state and the size of its apparatus of control changed to respond to the fluctuations of the world 
economy, in an effort to protect settler production. Conflicts, crises, and contradictions within the colonial state itself (see TABLE I and TABLE II), particularly the increased political awareness of the Africans, followed which definitely eroded the legitimacy of the colonial state and caused its end. Five periods can help to analyze the policies of the colonial state and their consequences: before 1920, the 1920s, the 1930s and the Great Depression, the 1940s, and the 1950s after the insurrection. In each period, the policy of the state is investigated. Conflicts and their consequences are assessed.

Before 1920. At the on-setting of the colony and its settlements, British settlers used brutal force to subdue African tribes, confiscate their land, and coerce them to labour. In 1914 increased settler brutality on Africans by settlers nearly caused a collapse of the colonial state. The state's reaction to this threat was a policy that took control over recruitment of labour supply for settler estate production. Through the Provincial Administration, the state applied direct coercion to provide African laborers. The labour force came from (1) the Western Highlands (Nandi, Gishu, Uasin, Trans Nzonia), (2) zone of Ravine, Nakuru, Navaisha and Laikipia in the Rift Valley, and (3) Nairobi, Kiambu, Machakos, Kitui, Voi, Mombassa and the coast, and the eastern highlands of Kiambu and Nyeri Kikuyuland., Therefore, coercion was institutionalized by the state police to help the setters at the expense of African interests.

The colonial state faced resistance because the Africans not only felt betrayed by the colonial state, but they were also unwilling to stay on the job. In response, the state instituted a policy of squatting in 1918 through the Residence Native Labourers as means of control. ${ }^{7}$ A contradiction arose from this arrangement because squatting became a threat to settler production in the local commodities and some cash crop export commodities such as maize. Between year 1919 and 1922 the state applied direct coercion more than

\footnotetext{
7 Squatters worked for the settlers in exchange of renting a piece of land for their own cultivation.
} 
squatting to provide African labour to the settlers. Another major policy of control was the institution of a heavy taxation on the Africans with the hut tax that brought more than 50\% of state fiscal revenues before W.W.I. Added to the policy of coercion through squatting and taxation was the psychological policy of paternalism and demeaning of Africans who were publicly considered as unable to take care of themselves.

During this period there were two kinds of struggles. The first category was over settler versus metropolitan interests. The second kind of struggle was between settler and Africans seen at two levels: alienation of African land by the settlers, and commodity production because African production competed with settler production. On each side the state sided with the settlers to protect their interests that were vital to the economy of the colonial state (see TABLE I).

The 1920s. The 1920s' period started with an increased coercion of Africans to forced labour by the colonial state. Between the year 1919 and 1922, hut tax on Africans increased while wages paid to Africans working in state projects were very low. The tax revenues went to support settler agriculture after the minor depression of 1921-1922. It can be understood that increased taxation was used as means of controlling African production and to coerce them to labour for the settlers (squatting to pay taxes). Another method of control was the establishment of official boundaries on African reserves.

A contradiction emerging from this policy was that on one hand the Provincial Administration wanted to protect Africans from further land alienation and on the other used them as labour supply for the settlers. Another contradiction that the state faced stemmed from its claim of neutrality while it favored settler interests against African interests. As a consequence in 1921-1922 an African protest was led by Harry Thuku that marked the birth of the first forms of African political awareness through political organization. 


\section{TABLE I}

\section{KENYA'S COLONIAL STATE: CONFLICTS}

\begin{tabular}{|c|c|c|}
\hline Conflicts & Within the colony & Outside colony \\
\hline $\begin{array}{l}\text { (1) } \\
\text { Clash between } \\
\text { interests }\end{array}$ & $\begin{array}{l}\text { - Africans versus settlers over (1) } \\
\text { confiscation of African land. (2) } \\
\text { destruction of African economies to } \\
\text { force them into colonial economy, } \\
\text { and (3) control of African } \\
\text { production to favor settler } \\
\text { production. } \\
\text { - Opening access for Africans to the } \\
\text { leadership apparatus in the colonial } \\
\text { state. } \\
\text {-Within the colonial adminis- } \\
\text { tration: between the Central } \\
\text { Administration based in Nairobi } \\
\text { and the Provincial Administration } \\
\text { in the "African areas." }\end{array}$ & $\begin{array}{l}\text { - The colonial authorities in Kenya } \\
\text { and the metropolitan authorities in } \\
\text { London over policies of the } \\
\text { colonial state. } \\
\text { - Between metropolitan business } \\
\text { interests and settler/colonial } \\
\text { economic interests: the colonial } \\
\text { state favored settler production that } \\
\text { was the back bone from which the } \\
\text { colonial state derived income from } \\
\text { exports. Until W.W.II, the } \\
\text { colonial state prohibited African } \\
\text { production of cash crops that would } \\
\text { have been bought cheaper by } \\
\text { metropolitan merchants. }\end{array}$ \\
\hline $\begin{array}{l}(2) \\
\text { Economic }\end{array}$ & $\begin{array}{l}\text { - High taxes and forced labour on } \\
\text { Africans, and low wages to African } \\
\text { workers. } \\
\text { - Failure of the colonial state to } \\
\text { give benefits to the ex-askaris } \\
\text { - Destocking policies against } \\
\text { Kamba cattle in favor of settler } \\
\text { meat production. }\end{array}$ & Hen \\
\hline $\begin{array}{l}\text { (3) } \\
\text { Political struggle } \\
\text { between Africans } \\
\text { and the colonial } \\
\text { state/settlers }\end{array}$ & $\begin{array}{l}\text { - Banning of African political } \\
\text { activity by the colonial state. } \\
\text { - African struggle for access to the } \\
\text { apparatus of the colonial state. } \\
\text { - The Mau Mau armed insurrection. }\end{array}$ & -- \\
\hline
\end{tabular}

During the 1920s the Kenya administration was a conservative apparatus of control. The government was elitist, paternalistic towards Africans, authoritative and used the ideology of psychological domination of Africans. The paternalistic attitude insisted on the helplessness and the incapacity of the ruled Africans to govern themselves and to achieve their own interests. However, the colonial state faced the dilemma of satisfying settler interests versus African interests while maintaining its autonomy. 
TABLE II

\section{KENYA'S COLONIAL STATE: CONTRADICTIONS}

\begin{tabular}{|c|c|c|}
\hline Contradictions & Within the colony & Outside colony \\
\hline $\begin{array}{l}\text { (1) } \\
\text { Mission versus } \\
\text { practice }\end{array}$ & $\begin{array}{l}\text { - The colonial authorities claimed neutrality } \\
\text { and to protect African interests. Instead they } \\
\text { aided settlers to confiscate African land, to } \\
\text { force Africans to labour for settlers, and to } \\
\text { pay more taxes to the state for infrastructures } \\
\text { that did not benefit them. } \\
\text { - The colonial authorities claimed to protect } \\
\text { Africans from settler brutality, yet they used } \\
\text { military force and coercion to force Africans } \\
\text { to labour for settlers. } \\
\text { - The colonial authorities claimed to protect } \\
\text { African culture and societies, yet they broke } \\
\text { their way of life. Their paternalistic attitude } \\
\text { and racism demeaned Africans and destroyed } \\
\text { their self-confidence. }\end{array}$ & $\begin{array}{l}\text { To be a neutral player between } \\
\text { settler interests and metropolitan } \\
\text { interests, yet the colonial state } \\
\text { favored settler economy versus } \\
\text { metropolitan business interests. }\end{array}$ \\
\hline $\begin{array}{l}(2) \\
\text { Governance }\end{array}$ & $\begin{array}{l}\text { The colonial government wanted centralized } \\
\text { control over the life of the colony. Yet it } \\
\text { implemented a dualistic system with two } \\
\text { parallel administrations: the Central } \\
\text { Administration based in Nairobi and the } \\
\text { Provincial Administration in African areas } \\
\text { whose policies and authority often collided } \\
\text { over African interests and issues. }\end{array}$ & $\begin{array}{l}\text { The colonial authorities and the } \\
\text { metropolitan authorities in London } \\
\text { over mistreatment of Africans, for } \\
\text { example. }\end{array}$ \\
\hline $\begin{array}{l}\text { (3) } \\
\text { Racism and } \\
\text { segregation }\end{array}$ & $\begin{array}{l}\text { The colonial authorities vowed to help } \\
\text { Africans in a paternalistic attitude, yet the } \\
\text { relationships in the colony became } \\
\text { increasingly racist and segregative of } \\
\text { Africans. }\end{array}$ & -- \\
\hline $\begin{array}{l}\text { (4) } \\
\text { Primacy of state } \\
\text { control over the } \\
\text { economy }\end{array}$ & $\begin{array}{l}\text { Created much burden to the economy } \\
\text { particularly indebtedness because of railway } \\
\text { construction and other spending of the } \\
\text { colonial state over infrastructures. }\end{array}$ & -- \\
\hline
\end{tabular}

The 1930s. The period of the 1930s was marked by the Great Depression in capitalist economies. Kenya's economy, dependent on exports to Britain was hit hard. Settler production decreased because of debts. The state, because it relied on settler exports and metropolitan capital, was heavily indebted; it had enormous debts incurred on public works 
and the loss of revenues from imports and exports. Influenced by Keynesian economists, many governments in the world including the United States embarked in strong state control of economies; Colonial Kenya did not escape the trend.

In order to keep the economy afloat, the government engaged in a contradictory policy of encouraging African production of cash crops by the most wealthy petty African peasant bourgeoisie of collaborators and squatters. They were allowed for the first time to grow the most profitable cash crops such as tea that remained the most profitable crop during the Great Depression. The increase in African production attracted metropolitan merchants who preferred cheap African commodities over settler commodities. Therefore, this negative externality put the state in a dialectical situation of promoting an increase in African production and at the same time controlling it to protect settler production.

The Government during this time engaged in similar policies to protect settler production and interests. Such policies were the destocking of Kamba cattle in 1938 (Myrick 1975) which drew a wide protest by the Kamba. Along side this line the government declared the Kikuyu Central Association (KCA) illegal and used repression against the increasing political organization of Africans. However, until the 1952 crisis, metropolitan and settler interests dominated the political arena in Kenya and directed the development of the political economy of the colony.

The 1940s. This period saw increased political awareness and political organization of Africans. Because of statewide political awareness and organization, rebellion broke out in 1952. It triggered a wave of reforms from the colonial state to the benefit of Africans. The reaction of the colonial state was of increased repression. Some reforms started by Eliud Mathu ${ }^{8}$ led to some liberalization, mainly the increase of access by Africans to the Legislative council. However, discontent in African reserves due to scarcity of land and land alienation from the Africans caused the Kikuyu-led Mau Mau revolt engineered by the 
KAU in 1952. This revolt severely eroded the legitimacy of the colonial state which used brutal force and the help of metropolitan forces to crush the rebellion. However, because of the fear of total political collapse in the colony, the loss of British economic power and British involvement in the Suez crisis, and social pressure in Britain favoring the removal of colonial grip over Kenya, the colonial state disappeared in the late 1950s.

The 1950s. The most important development in Kenya during the 1950s was the eclipse of the colonial state with decolonization process of Kenya from 1954 to 1963. As Berman suggests, decolonization of Kenya was mostly due to the change in the political economy of the colony and its integration in the unstable world economy. The character marking the change was determined in the articulation of international capital with indigenous social forces, particularly the peasantry and the petty bourgeoisie. What explained this change was not only the rise in Kenyan nationalism but also changes in the political economy of the colony and the emergence of social forces such as the African petty bourgeoisie class. The climax of the change came in 1954 with four new major state policies that transformed the politico-economic structures of the colony (Berman 1990):

1. The Swynnerton Plan for the development of African agriculture The Plan released restrictions on commodity production by Africans in the reserves. It accepted the development of capitalist forms of property of land and production in the reserves through the active promotion of cash crop production. The Plan removed previous restrictions on African production of the most profitable cash crops such as coffee, tea and pyrethrum. It envisaged an expansion of African coffee production and provision of credits to Africans. However, the Plan recognized that it would lead to a formation of classes among the Africans: the land rich and the landless. It was assumed that the landless would work as a labour-wage force for the 
wealthy peasants. However, the ones who benefited the most were the collaborators of the colonial state among the Africans.

2. The Report of the Carpenter Commission on African wages It accelerated the transformation of relations of production in the colony to meet the need of growing industrial investment by international capital.

3. Shift of political control of African reserves

During the rebellion political control shifted from the paternalistic Provincial Administration to the Central Administration in the practice of control and collaboration. Hence, the dual administration that had prevailed before 1952 eclipsed.

4. Constitutional changes

They encouraged the emergence of an African petty bourgeois African nationalism and fostered direct collaboration between the natives and the metropolitan authorities.

The Swynnerton Program brought an unprecedented economic lift to Kenya. The GDP increased 6\% between 1954 and 1964 (see Figure 6). However, the contribution of agriculture to the GDP did not change much (30.9\% in 1954 to 31.3\% in 1963; see Figure 7). The consequences of state policies were the major reason of its dismissal in the late 1950s.

Three main aspects can be investigated. First, the state economic policy that relied too much on cash crop production for exports made of the Kenyan economy totally dependent on great Britain. The economy, therefore, suffered the fluctuations of world economy, especially the imbalance of terms of trade in commodities. The shocks of the 1921-1922 depression and the Great Depression on the settler-dominated economy can be taken as cases to justify the dependency claim. 
Second, the policy of the state favored the settlers, dispossessed Africans of their land, and exploited them through an unfair system of taxation, forced labour, and production control. Therefore, it brought resentment of Africans against the colonial government and its legitimacy. The rise of African political consciousness and political organization starting from 1920s and increasing nationwide in the 1940s, ended with the Mau Mau rebellion of 1952 that started the decline of the colonial state.

Third, the government reforms of the Swynnerton Plan after the state of emergency in 1954 , brought a rapid growth of African commodity production and decline in importance of settler agriculture. Two major consequences followed the reforms. First was the creation of class differences among Africans in African areas. The Swynnerton Plan with land reform and commodity crop liberalization offered the possibility of African individual ownership of land in those areas and increased the class differences among Africans. The immediate consequence was the Mau Mau peasant uprising against the settlers and the landrich African. However, those who were favored the most by the Plan were the "collaborators" of the colonial government, especially chiefs and headsmen. They soon became a class of land rich and petty peasant bourgeois, while a class of landless emerged who worked in farms for wages or as squatters. The consequences of creation of African classes continued with the independence. For example, after the land transfers from the settlers to Africans in the late 1950s, people who bought the settler farms, plantations and estates were among the petty peasant bourgeoisie and the elite in the Kikuyu group mostly. Second, the policy of cash crop liberalization drew many peasants to cash crop production at the expense of food crop production as will be analyzed in the next sections.

Some elements and circumstances helped the colonial state to achieve its policies and goals. The pillars of what helped the colonial administration in controlling Africans were found amongst the collaborators of the Provincial Administration and Africans themselves: the chiefs and headmen, the courts or Native Tribunals, and the Local Native Councils. 
The African chiefs helped the colonial authorities in mobilizing African labour and production for the colonial economy, and played a role of spokesmen for Africans.

The colonial administration used prestige as another tool to dominate Africans: stereotypes, segregation and paternalistic attitude to demean the natives. The Africans were, therefore, convinced that they were not able to take care of their own governance and welfare. This paternalistic attitude justified the actions of the colonial state on behalf of Africans, which instead of helping the latter exploited them at the benefit of the settlers. The paternalistic strategy of the colonial state was achieved by the Provincial Administration that was in charge of African districts. The colonial state in addition withheld information from the mostly illiterate African populations to foster control and domination.

The existence of the colonial state can be summarized within the context of a class struggle and a struggle for control. The class struggle can be found at two levels: (1) between the settlers and Africans over land alienation, crop production and economic power share, and (2) among the wealthy and land-rich Africans versus the poor, dispossessed and landless Africans. The struggle for control was centered on the colonial state itself. First, the colonial state controlled the Africans to create its own legitimacy. Second, it controlled and coerced the Africans to protect and promote settler economic interests. Third, the colonial state was in a struggle of control and legitimating between two sets of contenders at the political and economic levels. At the political level the crisis of control between the settlers and the Africans over representation in the organs of the state moreover in the control of land. At the economic level the state used control upon African production to favor the settlers on one hand. On the other hand the state controlled the struggle between metropolis capital and investors versus settler capital; settler interest was given more priority by the colonial state. 
The crises of the colonial state developed as Myrick suggests on three aspects: (1) confrontation between the government and natives at the local level, and between settler and natives over land alienation and confiscation, (2) the issues of labour market in the colonial state, coercion of African labour, and demobilization-remobilization of ex-askaris, ${ }^{8}$ and (3) the political struggle for more representation for Africans in the state apparatus especially in the Legislative Council.

\section{THE EVOLUTION OF AFRICAN POLITICAL ORGANIZATION}

Early signs. African political organization surfaced in 1922 as a reaction to forced labour and coercion by the colonial state to satisfy settler interests (Berman 1990; Macphee 1968). Between year 1919 and 1923 serious challenge to the colonial statusquo by the Kikuyu and the Luo came from the reserves. They had for long time felt deep resentment toward the government since 1914. Political activity started among these two groups. In Nyanza a Young Kavirondo Association was formed. In Kikuyu areas Harry Thuku founded an East African Association in Kikuyu areas. Both organizations emerged as reaction to (1) increased taxes on Africans, (2) unpaid compulsory labour on public works by the state, (3) the use of coercion on Africans by the government to work on settler farms, (4) the "kipande" registration system for Africans, and (5) the alienation of tribal land to white settlers. Violence and demonstrations in 1922 erupted as a result.

In 1922 the KCA (Kikuyu Central Association) was formed by educated young men involved in opposition against African chiefs and collaborators of the Provincial Administration; its headquarters were in Nairobi. KCA claims focused on distribution of land in the reserves and security of Kikuyu land from further alienation. In 1928 Jomo 8
$1968)$.

The askaris were Africans enrolled in the British armed forces in East Africa (Myrick 1975; Shiroya 
Kenyatta became the general secretary of the organization. The KCA also resisted missionaries by strongly supporting the preservation of African customs. Jomo Kenyatta presented grievances of the KCA to Colonial Office in London. It proved for the first time that Africans were able to organize themselves effectively and challenge the paternalism of the Central and Provincial Administrations.

Rise of political consciousness. During most of the 1920s and early 1930s, African political organization had not emerged state wide. It concentrated in rural areas among the land-expropriated ethnic groups mainly the Kikuyu. The state used co-optation to control Africans and increased repression of nationalist movements. Elements of co-optation included encouraging Africans to produce cash crops during the Great Depression while at the same time the government controlled their production and imposed almost $70 \%$ of total tax burden on Africans.

African political organization did not begin to emerge as a colony-wide organization until late 1930s with events such as the Mombassa workers strike of 1937/1938, land shortages in the reserves, and the destocking crisis in the Kamba area in the Machakos District (Myrick 1975) which furthered more political awareness among different ethnic groups in the colony.

Widening of the African struggle and political organization: the Mau Mau rebellion. In the 1940s, political consciousness of Africans increased due to three kinds of factors. The first factor was the influence of the ex-askaris on nationalist movements. ${ }^{9}$ Keys to the

9 See Okele J.E Shiroya (1968) and D.L Easterbrook (Myrick 1975). Segregation in the armed forces and the feeling of inferiority increased the askaris's resentment against the British. Most of all, they had fought hard in North Africa to expel the axis forces, and in India and Ceylon. They expected reward from the colonial administration granting them more concessions, better pay and right to engage in business. They had been exposed to new ideas in their contacts with British and allied soldiers (for example Black American soldiers) and they had seen the way of life elsewhere. In 1944 the problem of demobilization of the ex-askaris was an issue for the colonial administration and the settlers who feared their influence on the growth of native Kenyan nationalism. 
emergence and spread of African nationalism in the 1940s were the ex-askaris. The war time experience of the ex-askaris had raised their political consciousness against British colonization and their expectations of reward for services. However, after the war, demobilization policies did not really satisfy their expectations. They spread political awareness among the populations and many participated in workers strikes such as the Mombassa strikes of 1937/1938 and 1947, and fought along the Mau Mau.

The second element is that the period 1944-1952 was marked by deep political struggle and a crisis in the colonial state (Berman 1990). Colonial wartime production and demands accelerated the physical deterioration of the soil in the reserves, making subsistence agriculture difficult for Africans. A consequence was an accentuated gap between Africans and the increasingly prosperous sectors of the economy controlled by the Europeans and the Asian traders. Mass political activity began to emerge as African nationalism in the reserves began to spread nation-wide. The Provincial Administration tried to contain Africans in the reserves by using paternalistic welfare methods. The result of this was the emergence of a wealthy class of peasant who were given access to land and cash crop production.

The third element was the increasing access of Africans to central organs of the colonial state apparatus. In 1944, Africans gained first access to the Legislative Council when Eliud Mathu was appointed. Mathu's program for government reforms included education for all, land reform, labour reform, agriculture reforms, and increase of African representation in the Legislative Council. ${ }^{10}$ Mathu succeeded in most of these policies during his time as

However, the expectations of the ex-askaris were not met by the colonial state. They were put in reserves and controlled by the colonial state, what prevented them from forming a political organization. One source of weakness of the ex-askaris was their high degree of illiteracy. However, they spread awareness among the populations who respected them for their war experience. Some participated in the $\mathrm{KCA}$, strikes and fought in the Mau Mau uprising.

10 J.R. Roelker (Myrick 1975). Eliud Mathu's policies were based on humanistic, pragmatic and non-violent method. He promoted a policy of self-help for Africans at the same time envisaged a multiracial society culturally based on model of British society and organization. These tenets would be embraced by Kenyatta after the independence. Mathu sought an educational reform for multicultural school 
African representative in the Legislative Council. His policies were continued or granted with the Swynnerton Plan and the Carpenter Labour Commission. However, with the failure of land reform policies, struggle increased within African political organization. Therefore, expansion of African political struggle grew.

Post W.W.II African nationalism had its origin in the Kenya African Union (KAU) which was founded in 1944 as Kenya African Union (Duignan and Jackson 1986). Jomo Kenyatta led the KAU after his return from England in 1947. The KAU fought to promote African interests and most of all concentrated on the issue of land alienation, which put them at odds with the Provincial Administration. ${ }^{11}$ The Provincial Administration reacted with increased oppression of the Kikuyu and KAU members. Therefore, it led to the Mau Mau oath supported by Kenyatta. In 1952, the oath was made illegal by colonial

system open to all. He also proposed the change of the kipande system to a national registration system that passed. He advocated land reform. However, this measure failed because the government wanted to maintain a dominant European community in the colony.

Eliud Mathu sought the restoration of at least part of the confiscated Kikuyu land. He recommended removal of restrictions on cash crops to Africans as well as assistance to African farmers. Some of the failed initiatives, at the exception of the restoration of Kikuyu land, were embraced by the Swynnerton plan. Mathu fought for increased representation of Africans in the Legislative Council. He sought also the improvement of conditions of African labour and the attitude of European settlers towards African labour. As a result in 1945 some Africans were allowed to buy a store in Nairobi, and wages were increased after the Mombassa strike of 1947.

In result Mathu's policies succeeded except the land reform. His leadership provided a solid ground for a change in African politics. The number of Africans in the Legislative Council grew to 6 in 1952. He was defeated in the 1957 elections.

11 The KAU's objective was to promote African interests and provide support to Eliud Mathu in the Legislative Council (Duignan and Jackson 1986; Berman 1990; Macphee 1968). KAU became a central forum of African political activity nation-wide and claimed access to central political institutions of the colony. Externally, KAU sought support of sympathetic British politicians and organizations, and established links with fellow nationalists in Uganda, Tanzania and Ghana. It placed importance on the issue of land alienation and the abolition of the kipande registration system. KCA was banned in 1940 because its members had supported the 1939 Mombassa strike. However, they continued political activity within KAU but had more influence among peasants in the Kikuyu reserves and the squatters in the Rift Valley. KAU action developed with the support of the 1947 Mombassa strike which sought wage increase for African workers. The colonial state reacted with neglect of KAU requests and more repression.

The KAU strongly opposed the policies of the Provincial Administration who qualified them as bad guys. The increased oppression led to a new form of political movement within the KAU: The Mau Mau oath. It was a unification among Africans to fight oppression. Kenyatta encouraged the oath in the sectors of the proletariat and the populations in Nairobi and other cities. In 1952 the oath was made illegal and many Airicans were imprisoned among whom prominent leaders of KAU. British troops were sent to the colony. Kenyatta and 145 other leaders most of them Kikuyu were arrested and jailed. The state of emergency was declared in October 20,1952 and the state used naked forces to restore control. 
authorities. As a result Kenyatta and other African political leaders were arrested for subversion and imprisoned. The KAU was subsequently banned in 1953 following the declaration of the state of emergency.

The Mau Mau started a series of violent attacks against settlers and African collaborators such as chiefs and headmen. The first phase of military operation started in 1952. With metropolitan political and military backing, the colonial state moved to crush radical challenge through massive force and imposition of direct administrative control. Many among the Mau Mau and the civilian populations were killed or wounded. The weakness of the Mau Mau was that they were poorly armed and poorly trained in warfare. The Mau Mau were crushed in 1954 with many killed or imprisoned. 12 In 1959 under pressure from British public opinion and sympathizers among officials, the Mau Mau fighters at the exception of political prisoners were released. Essentially, the Mau Mau was a peasant uprising against land alienation and coercion. The rebellion can be analyzed as a class struggle, i.e., an uprising of the "have not" against the "have," indiscriminately European settlers, Indians, or Africans.

Political and economic reforms. Between year 1953 and 1954 the colonial government began programs of reconstruction of the Kikuyu society to restore order. The Provincial

12 In 1953 some 15000 Africans mostly Kikuyu, but also Meru, Embu and Kamba, Maasai entered the forests in resistance groups under the leadership of Dedan Kimathi and Stanley Mathenge into a Land Freedom Army around Mount Kenya (Berman 1990). The Mau Mau was portrayed as a savage organization of bandits by the Government and Kenyatta seen as the chief organizer. The media often dehumanized the Kikuyu fighters to draw allegiance from the civilian populations.

The Mau Mau conducted attacks against the settlers, colonial police and collaborators of the African upper class such as chiefs. However, they had weaknesses: lack skills in warfare especially guerrilla, and organizational problems. As a result they suffered heavy losses in 1954 when As of 1954, reinforcements were sent from Britain in 1954. Government troops conducted indiscriminate killings against the civilian populations in the Kikuyu, Embu and Meru districts. By mid-1954 Mau Mau resistance began to wane down and their raids ceased. By the end of 1954 18,069 Kikuyu, Embu, and Meru were imprisoned and close to 1000 were executed for participation in killings. By 1956 the military operations of the Emergency ended. The total figure was 11,503 Mau Mau killed, close to 3000 captured, 95 Europeans killed, 2000 loyal Africans killed and others wounded. The Government soon after engaged in a campaign of deconstructing the Mau Mau. However, pressures from the metropolis media and public opinion demanded the release of the Africans. In 1959, the colonial government released the prisoners. 
Administration worked to control the peasants by regrouping them in villages and started issuing individual titles to land. Furthermore, prohibition of African production of coffee and pyrethrum was removed in the reserves and replaced by control of the production.

After the Swynnerton reforms of 1954, the weakening of British economic power, increased pressures from Africans and their access to central organs of the colonial state (six representatives in the Legislative Council) combined to give way to the first open elections in 1961. During the 1952-1960 emergency period, the role of the Provincial Administration had resurfaced. However, the declaration of the State of Emergency (19521960) was synonymous to the evaporation of the colonial state's legitimacy and collapse of its control in Kikuyu reserves, the African locations of Nairobi, and the countryside. The colonial authorities confronted not only a resistance movement but also a growing class struggle in the reserves. It can be suggested that the Emergency had its roots in the accumulation of contradictions emerging from the distribution of land, relations of production, and the process of class formation.

Pre-independence: Africans in political leadership. The general election of 1961 was overwhelmingly won by the Kenya African National Union (KANU) whose presumptive leader, Jomo Kenyatta, was still being detained by the colonial authorities as the alleged leader of the Mau Mau movement. KANU refused elections without its leader Jomo. The KADU minority (Kenyan African Democratic Union) agreed to form a decentralized government with the Europeans and Asians, and drafted the "Majimbo" provincialism constitution that was designed to protect the ethnic minorities.

Pre-independence elections were held in June 1963. They were won by KANU, which formed what was to be the first independent African government of Kenya. Kenyatta who had been released from detention in August 1961 became Prime Minister. The "Majimbo" provincial constitution was not substantially implemented by the Kenyatta government 
whose basis of political support was the majority ethnic groups, particularly the Kikuyu and the Luo. In December 1964 the emergent state was transformed into a unitary republic with Kenyatta as its first president. Kenya became de facto a single party state then, for, many KADU leaders joined KANU in the knowledge that otherwise they would not participate in the patriarchal government of Kenyatta.

\section{THE ECONOMY OF COLONIAL KENYA: MAJOR DEVELOPMENTS}

The economy of colonial Kenya was essentially based on agriculture for exports of cash crops such as coffee, tea, sisal, pyrethrum, maize (Berman 1990; Ochieng 1990). These products were exported to England and a portion of the revenues was used by the state on public projects. Until the reforms brought by the Swynnerton Plan in 1954, the export economy was dominated by the settler production because the settlers had monopoly over production of lucrative cash crops such as coffee, tea, sisal, wattle, pyrethrum. The settler economy achieved a surplus because they used free African labour. It is also essential to note that before the mid-1930s British policy strictly restricted competitive manufacturing in the colonies. This means that manufacturing and industrialization were practically non-existent in Kenya before this period. However, during the Great Depression British firms and authorities allowed production in the colonies to counter the high penetration of Japanese products, especially in East Africa. It is after this liberalization of colonial policy that industrial capital investment began to penetrate Kenya in the years following the second world war.

Two key characteristics of the economy as stated at the beginning of this chapter were its cash crop export base and its dependency on the metropolis (England) for capital and market. Added to these two characteristics were the increased state control and intervention in the economy, mostly with policies to protect settler production by controlling African 
production. It should also be noted that settler interests often conflicted with metropolis capitalism, especially regarding the price of commodity exports. Therefore, cheap African commodities presented a great competition for settler products.

The young dependent economy of colonial Kenya was by its nature very vulnerable to fluctuations in the world economy, especially the international economic depression of 1921-22, and the Great Depression of the 1930s. Government policies often changed dramatically to respond to these fluctuations. Berman's study provides a broad view of Kenya's colonial economy from the on-set of the colony to the independence years. The analysis in this section borrows from Berman's study to discuss major developments in Kenya's economy during the colonial period.

Before W.W.I. It was suggested earlier that from the on-set of the colony, Kenya's economy became a cash crop export economy dominated by settler production. The revenues from exports of cash crops provided roughly $16 \%$ of total GDP of the colonial economy. African production of less lucrative crops such as maize and simsim of African origin provided the basis for domestic consumption, and its output far more exceeded settler production in those areas. The boom and bust in the world economy in 1921-1922, due to an attempt to restore the gold standard hit the Kenyan economy, especially settler production. Settler agriculture because it was dependent on forced labour from Africans suffered tremendously. As a consequence, the state increased coercive policies of forced labour and a total control of African production to protect settler production. However, during the late 1920's settler production began to decline because of ILO (International Labor Organization) regulations on the treatment of labour force. The settlers had now to pay a meager wage to African labour. 
The Great Depression years and after the Second World War. The Great Depression hit the economy harder, due to the lack of capital investment. The colonial economy as a whole and the settler economy particularly became indebted. Therefore, the government under pressure by metropolis capital encouraged African production of non-lucrative cash crops. Many metropolitan companies following government reforms, started investing in Kenya after W.W.II. After the Mau Mau uprise in 1952, government reforms, particularly the Swynnerton Plan removed restrictions on cash crop production by Africans. Production increased for both Africans and settlers as a consequence and an African bourgeois class of merchants, smallholders and wealthy peasants emerged. Also as Berman suggests, by the times of independence in 1963, government policies encouraged foreign investment by multinational corporations and the economy acquired a sizable industrial sector. This aspect made the third characteristic of the Kenyan economy--a high degree of foreign investment in the industrial sector by multinational corporations. However, the Kenya economy after independence remained heavily reliant on commodity crop exports, especially coffee and tea.

\section{THE AGRICULTURE DEVELOPMENT POLICY}

Since the beginning of the colony as has been covered above, agriculture has constituted the backbone of colonial Kenya's economy. From the on-setting of Kenya as a colony up to the early 1930s, agriculture development policy was almost entirely dominated and controlled by European settlers because of their overwhelming influence on the colonial state (Heyer et al. 1976). In spite of the Great Depression and W.W.II which forced the government to encourage African agricultural production to keep the economy afloat, European settlers dominated the formation of agricultural policy. Key aspects of agricultural policy undertaken by the state are examined in this section. 
Settler farming: key sector of colonial economy. Before the State of Emergency in the 1950s, settler farming was the backbone of the Kenyan economy as Heyer's study and the others referenced previously suggest. Settler oriented policy in summary sought to give settlers surplus production and a total advantage over African production. The policies can be classified under six categories: land alienation, control over labour supply, control over crop and livestock production, control over research and advisory services, control of fiscal policy, and control over transport policy and freight rates.

The policy of land alienation that started at the beginning of the century put 20 per cent of the total usable land area for exclusive European use as the studies cited have shown. The consequences were (1) increased pressures in the African reserves for land, (2) increased conversion of peasants to squatting for settler farms to have access to land, and (3) serious problem of soil erosion in African reserves due to high population density.

The policy of control over labour supply was aimed at providing settler's farming with free or cheap African labour that guaranteed settler surplus production. Settlers and colonial authorities used four kinds of strategies to obtain African labour force. First was the imposition of a high hut tax on Africans introduced in 1901 for all male over sixteen. The tax policy pushed Africans to the cash crop economy and to work for settlers to pay the taxes. The second strategy was the 1909 'resident labour' or squatter system. African families were given settlement on European farms and worked for the settlers in exchange for the right to cultivate land and graze livestock. In the 1920s both the Kikuyu and the Kamba increasingly turned to squatting. The third strategy was the mandatory registration system for males, the "kipande" in 1921 to respond to the decline in labour supply of the settlers. All males were required to show a registration certificate of employment for the last six months or they were drafted in the army. This pushed many to work for the settlers to avoid the draft. The other obvious form of labour supply was coercion of the recalcitrant 
by the state forces, and the labour force provided by chiefs and herdsmen (collaborators of the Provincial Administration) who used ethnic paternalism to obtain compliance of their subjects.

The policy of control over crop and livestock production opposed African production of certain crops to protect settler leading advantage. Such crops were the lucrative coffee and tea. Also, European settlers aimed at controlling native production of meat that was far dominant in numbers and in pre-colonial Kenya was the main mode of production for the pastoralist.

Control over research and advisory services implied that the Agriculture Department before 1923 exclusively concentrated on the "scheduled" (settler) areas. It is only starting from 1923 that a handful of officers were sent to the "non-scheduled" (African areas).

Control over fiscal policy implied as covered previously that increased taxation was imposed on Africans either to force them to labour for the settlers or to pay for the cost of public infrastructures such as roads and railways that benefited European settlers and Indian petty traders the most. Between year 1920 and $192370 \%$ of the tax revenues of the state was contributed by Africans (Heyer et al. 1976).

Control over transport policy gave advantage to the settlers to use the infrastructures paid by the revenues of taxation upon Africans. Those infrastructures, particularly the railway and major roads helped settlers to transport their products for distribution and exports. Settlers were given priority use of these infrastructures.

The policies discussed above changed significantly starting from the on-setting of the second world war. The government liberalized cash crop production a bit to complement the settlers' domestic production that had declined because of indebtedness starting with the Great Depression.

In 1946 a Ten Year Plan launched the start of economic incentives for Africans. Definitely the 'Agrarian Revolution' of the 1950s increased economic incentives for African 
production of market crops. The Emergency of 1952 provided a stimulus to accelerate development of African agriculture (Heyer et al. 1976). The plan in 1953 was to increase productivity in African reserves and to provide employment to the Kikuyu. The Government decided to draw up a plan for accelerated agricultural development of the Native Land Units. A plan was compiled by the Assistant Director of Agriculture, R.J. M. Swynnerton. The tenets of the Swynnerton Plan (which applied mostly to High and Medium Potential areas, i.e., the forest and highland areas) as covered in the other studies previously cited were: (1) land tenure which stressed liberalization of the sale of small parcels of land to peasant families in the reserves in order to allow them to produce food for subsistence, (2) consolidation and registration of holdings; the philosophy was that consolidation of smallholdings would increase the output of food production and agriculture, (3) the extension of agricultural services where teams of agricultural 'experts' would be in charge of districts, (4) agricultural research that had been confined to European farmers, (5) provision of agricultural credits to farmers by establishing a Loan Bank for African Farmers that became a recommendation of the World Bank in 1962, and finally marketing policies were to be organized through a marketing board system to avoid competing of settler and African production.

Agriculture reforms: the Swynnerton Plan. The Government reforms of the Swynnerton Plan have been praised for liberalization of cash crop production to Africans. Also land reform gave individual ownership of land to families. However, many critics have accused these policies of creating problems more than the intended benefits. For example, Berman accuses that the land tenure liberalization and land consolidation created a class of landless peasants, therefore, two classes within the peasant population: the landless, the land-rich peasants and the smallholders. Berman suggested that a proletarianization of the peasants 
followed as the landless had no option but to work for wages in the farms of the rich peasants.

Heyer et al. accused the policies of land tenure of creating disruption within the African system. Pre-colonial land tenure was 'communal' rather than individual and land was the primary mode of production. The disruption brought by land confiscation and land tenure reforms displaced pastoral and agricultural communities. It was accompanied by many problems of human adaptation: severe famines, livestock disease and plague, soil erosion. The land tenure policies created vast population of landless in the 1950s and 1960s and caused increased African consciousness over the land issue.

Colonial policies disturbed (1) the already existent establishment of ethnic boundaries, (2) the patterns of sustained economic activity within and among these ethnic groups that had existed before colonization, and (3) the equilibrium in the patterns of land use and availability, a balance that had been maintained in the shifting cultivation. The consequences of land fragmentation were soil deterioration through erosion and overstocking. To this extent some critics namely the Underdevelopment School (Leys 1975) ${ }^{13}$ accuses that colonization contributed not to the development or improvement of

13 Leys (1975) tries to answer the fundamental question about the significance of independence for the mass of people in former colonies, particularly in Kenya. This book is an examination of underdevelopment in Kenya. It starts with an inquiry into the relationship between 'private sector' in the Kenyan economy and the pattern of national development after independence in 1963. Leys suggests two starting points. First, the relation between the 'private sector' and the pattern of post-independence development could not be understood purely in Kenyan terms without taking into account international forces that came into play in the colonial setting of the country. Second, he suggests a critique that Modernization school and the economists tend to totally separate 'economy' from 'the political system' when it comes to ex-colonies. He contends that such views have often concentrated on the 'leadership' of the ex-colonies without an analysis of the way in which the different patterns of development embody different combinations of class interests and class struggle.

Leys follows with the examination of the relationship between neo-colonialism and underdevelopment applied to the case of ex-colonies, particularly Kenya. To start he defines neo-colonialism as "the formation of classes, or strata, within a colony, which are closely allied to and dependent on foreign capital, and which form the real basis of support for the regime that succeeds the colonial administration." He suggests that neo-colonialism can be applied not only to particular mode of imperialist policy applied to ex-colonies (AllAfrican Peoples' Conference of Cairo) but also as a characteristic form of the political, social and economic life-or of class struggle in certain colonies, i.e., where the transition from colonialism to independence permitted and efficient transfer of political power to a local elite that was closely linked with external interests formerly represented by the colonial state. Leys suggests that Kenya fell into this category of neocolonial state between year 1954 and 1963. On the other hand he considers it as a phase in the development 
the way of life of the Kenyan people, rather it disturbed what was sustainable to them, and left them impoverished and dependent on external market forces.

\section{FOOD PRODUCTION FOR DOMESTIC NEEDS}

Traditionally, Kenya has been primarily an agricultural country. From the ancient times (Ochieng 1990), food production in the region around Mount Kenya has rclied mostly on subsistence agriculture of food crop, and livestock raising. Shortages of the food crop and livestock commodities due to droughts or epidemics caused the nomadic pastoralist tribes, the Maasai especially, to engage in raids and wars against the agrarian groups such as the Kikuyu. Before the arrival of colonization and capitalist economy the abundance of these commodities was the backbone of a prosperous internal trade among the major ethnic groups. For example, the nomadic and pastoralist Maasai and Kamba exchanged cattle against food crops from the sedentary agricultural groups such as the Kikuyu and the Luo. In this section, the thesis doesn't present statistics about production and supply for this time. Rather, it tries to underline some policies of the colonial government over food production that can provide a basis to understand the food crisis in modern Kenya. Particular attention is put on the works of Berman and Ochieng. First, methods of food production are investigated and the impact of capitalist economic mode on those methods

of particular ex-colonies. Therefore, neo-colonialism is not seen as "the last stage of imperialism" ( as Kwame Nkrumah suggested) but as stage that gives way to other forms of imperialism as the result of two kinds of processes.

"On one hand, neo-colonialism reproduces and further extends underdevelopment, giving rise to new forms of class struggle with an indirect and subtle form of domination may prove inadequate to contain, giving way to more direct and crude forms. On the other hand, the process of neo-colonial underdevelopment seems bound to modify, and to be increasingly likely to disturb, the initial close relationship between domestic and foreign ruling classes which is its essential feature. Under most circumstances this implies that it is likely to give way to forms of 'dependent capitalist development' which resemble the old 'colonial system' less and less closely." 
assessed, then a discussion of the influence of government policies on food production is conducted.

R.M. Maxon (Ochieng 1990) suggests that since the earliest times agriculture has held a central role in Kenyan history more than pastoralism and had supported greater concentration of populations. Before the arrival of colonial rule, sedentary agriculture was practiced in communities using shifting patterns of land cultivation. The household practiced shifting cultivation on a piece of land rented to them by the community. ${ }^{14}$ The labour for agriculture was determined by kinship relations and was composed of the women in charge of cultivation and harvesting while the men were in charge of clearing the land for planting and cared for livestock. Therefore, the system was that of agrarian household production. The crops were mostly grain crops (millet, sorghum and maize) and vegetables. Most communities produced sufficiently for subsistence and exchanged their surpluses with other groups for commodities such as salt, weapons, artifacts, and meat.

The arrival of colonization altered the traditional patterns of agriculture in Kenya for three main reasons. First, it brought the capitalist system of production and exchange. Second, colonization caused confiscation of land from Africans. It also changed the pattern of land tenure, from community to individual ownership in African areas (1940s). Third, it created a dual agricultural economy, African and European. Mostly, European agriculture in the "White Highlands" was for exports of crops such as maize, coffee, tea, sisal, wattle, cotton, and pyrethrum to England. Until 1914, African commercial production in agricultural commodities was limited to crops such as maize and simsim.

With the coming of colonial rule, household production of crops such as maize, cassava and simsim increased in output, creating more dilemma and competition for settler

\footnotetext{
14 There was no individual ownership of land. Rather, the land belonged to the tribe who distributed a parcel of land to each family within the tribe.
} 
production of similar crops. Although land was confiscated from Africans, squatter's production in the "White Highlands" was increasing in output. In the 1920s, they produced most of the grain, vegetables, and dairy products for internal markets in the regions of Kiambu, Murang'a, Nyeri, Nyanza and Machakos. However, in the 1930s, the Great Depression hit the settler and African production. Particularly, in African areas, severe droughts and population growth caused severe shortages of arable land. In the 1940s, there was a crisis in African agriculture, mainly because of shortages of land, moreover the emergence of a class of wealthy African peasants who owned all the land. The class struggle for land ownership in African areas was a direct cause of the Mau Mau rebellion in the 1950s.

The government encouraged a substantial increase in the production of foodstuffs during the war as a measure of providing self-sufficiency during this critical period (Heyer et al. 1976). This effort led to an increase in the production of food crops, especially the important maize for sale by African farmers. The Swynnerton Plan in 1954 provided individual ownership of land in African reserves and encouraged cash crop production in African reserves. This unfreezing of land restrictions in the reserves increased divisions among Africans over land ownership, but led, however, to an increase of the yield of cash crops and food crops in the late 1950s and early 1960s.

M.A. Ogumu (Ochieng 1990) discusses cattle and livestock raising as another pattern of food production in pre-colonial and colonial Kenya. Since the early times, the cattle and livestock raising were mostly done by the Maasai, the Somali, the Luo and the Luyia. The cattle were needed to provide milk, ghee and meat. Nomadic pastoralism was mostly practiced by the Maasai, the Somali, Oromo and Rendile while the Luo and the Luyia practiced sedentary pastoralism. These groups as mentioned earlier practiced an exchange with sedentary agricultural groups such as the Kikuyu, Kamba, and Kalenjin. The colonial period introduced a commercial aspect to cattle raising by European settlers. The meat was 
now sold in modern butcheries in the cities and in local markets. Also the settlers brought animal veterinary services that helped the natives to fight animal diseases and diseases which at some times created shortages in Maasai stocks and triggered raids. As a result African livestock production increased. The settlers also practiced commercial ranching in the grassy areas of the Rift Valley.

Two issues related to pastoralism brought conflicts between the Africans and the settlers/government in the 1930s. First, overstocking in the Ukambani area in the Kambaland (due to improvements in animal care against diseases) competed with settler production and further rendered the Africans in those regions more reluctant to join the new forms of capitalist economy dominated by the settlers (Myrick 1975). Second, overpopulation of livestock by the squatters in settler estates and in the Kamba reserve (Machakos District) exacerbated soil erosion and competed with settler production. These two reasons pushed the colonial government under pressure by the settlers to pass the 1937 Resident Labourer's Ordinance in favor of protecting settler ranching. The policy eliminated squatter ranching in settler estates and forced destocking in the Ukambani and Kamba areas. The government confiscated and sold the Kamba cattle to settler meat companies, and used great quantities of animals to feed army soldiers in the armed forces.

Primarily dependent on cattle-based subsistence and economy, the Kamba reacted to the destocking policy by refusing to cooperate with the government. This incident ended in a crisis in 1938 known as the destocking crisis (Berman 1990; Myrick 1975). The incident raised political awareness of the Kamba that led to the creation of UMA (Ukamba Members Association) by S. Muindi Elijah Kaoulu. The organization established close links with the Kenyan Central Association dominated by the Kikuyu in Nairobi. With continued resistance of the Kamba, and the fear of extension of the protest to other groups, the government abandoned the policy in the end of 1938 . 
A conclusion can be drawn from the three studies (Berman 1990; Ochieng 1990; Duignan and Jackson 1986; Myrick 1975) that Kenya was self-sufficient in food crop and livestock production for domestic needs during the whole colonial period. Although, the land reform of the Swynnerton Plan did not eliminate the problem of the landless among Kenyan Africans, production in food crops, livestock, and cash crops had increased. Also, the population mostly rural and peasant at this time as the guess estimates show (4 million roughly from 1930 to 1948) 15 was not that big regardless of the considerable growth rate averaging 3\% per year from 1954 to 1962 (see Figure 8). However, considering the studies of Berman, ${ }^{16}$ Heyer et al, and Davidson to highlight that certain government reforms, especially land tenure and expropriation policy as well as cash crop policies, had an adverse impact over Kenya's self-sufficiency in food production and the way of life of the Kenya people. What happened was the increased dependency of peasants on cash crop production for their living either to earn money of their own, to pay taxes, or to work compulsory labour. In either case, the cash crop farms took labour and land away from food crops. It followed a gradual erosion of the self-help base in food production to meet the needs of the population that kept growing fast.

The first major government policy in the colonial state was the introduction of new capitalist mode of production and economy. As can be understood, the introduction of this new method of production and trade has had an impact on the peoples of Kenya. For example, Ochieng' suggests that before the arrival of the Europeans, agriculture and raising of livestock production was household production. However, with the new economy, trade was no more based on exchange of commodities among tribes, but on sale of commodities at the market to earn money as means of exchange. The impact on food production can be noticeable in the sense that food security that had been domestic since

\footnotetext{
15 See (Ochieng 1990, 19-21).

16 See also (Duignan and Jackson 1986).
} 
was now linked to the world economy (foreign currency) by way of the capitalist mode of economy. In some areas the price of food became a burden for the increasing proletariat. Also, forced labour in government public works, the settler estates, or recruitment in the Kenyan African Rifles deprived tribes with young men to work in farms and provide food supply for their tribes (Myrick 1975).

The second policy, was the expropriation of African land, especially in the Kikuyu and Maasai areas and the subsequent confinement in the reserves. Land confiscation deprived these groups of rich fertile lands in the Rift Valley where they used to practice subsistence agriculture. For the pastoralist nomadic tribes such as the Maasai, land confiscation disrupted their way of extensive cattle grazing. This policy deprived those groups with their essential primary mode of production, the land. As Duignan and Jackson's study supports, scarcity of arable land in the reserves, overpopulation and the cattle grazing provoked a decline in food production, therefore, household self-sufficiency in food production declined during the 1940s. Furthermore, the policy of the Central Administration did not specifically emphasize food production in any of the studies covered in this thesis. However, Berman suggests that the Provincial Administration insisted on self-sufficiency of Africans in household food production in African reserves. The Provincial Administration feared that food shortage could cause a social breakdown of African societies. Therefore, it would endanger the stability of the colony by rendering the provincial areas ungovernable.

The Swynnerton Plan of land reform and commodity crop liberalization offered the possibility of African individual ownership of land in African areas. However, those favored were the "collaborators" of the colonial government, especially the chiefs and headsmen. They soon became a class of land-rich and petty bourgeois peasants, while a class of landless peasants emerged who did not have any basis for food production. The 
landless worked for low wages as squatters in settler farms or for the wealthy landowner peasants. This by itself reduced their food supply because it depended on their wages.

Furthermore, a consequence that has captured particular attention in this research is the impact of cash crop liberalization of the Swynnerton Plan on household food production. Although many Africans became landless, the government encouraged the landless to work for the wealthy farmers. The plan envisaged increased African production of coffee and credits to African farmers. Therefore, from the late 1950s, tens of thousands of peasants entered the lucrative commodity production (Berman 1990; Duignan and Jackson 1986). The consequences included accentuated regional and class differentiation, inter ethnic inequalities, and most of all the drift away from the primary subsistence production of food crops. This caused significant decline in food production and growing reliance on market subsistence. As the international capital became linked with the petty bourgeoisie, it encouraged an elite class of African businessmen and politicians to cooperate with external corporate capital. This directly made the traditionally self-sufficient (in food production) peasant dependent on the internal/external market for subsistence. Therefore, a high level of capitalist penetration stressed by Berman characterized colonial Kenya.

It can be understood that colonial policy of cash crop production created a dramatic shift from sustained household food production to cash crop production for exports. The shift necessarily gave ground to a decline in food production, which was exacerbated with the doubling of the population at the independence (8 million in 1962.) An analysis of food production and supply during the post-colonial and contemporary Kenya deems helpful to justify this conclusion. 


\section{IMPACT OF POLITICS ON FOOD PRODUCTION IN THE COLONIAL STATE}

The analysis in this chapter reveals that three political forces entered into play in the Kenyan colonial state. Those forces were the settlers, the native Africans, and the colonial government itself. Clearly, the settlers were the most influential group in the colonial state, both economically and politically. The three forces often collided over divergent interests. To understand the impact of these forces on food production during the colonial period it is necessary to identify the interests of these forces and their interrelationships within the institutional framework of the colonial state.

It should be also considered that external forces came to play in the colonial state, not only forces to maintain British colonial empire, but also metropolis capitalism. Metropolis merchants tried to lobby the colonial state to encourage African production of cash crops which would be purchased at lower price than the settlers' commodities. However, the state was heavily influenced by the settlers and this did not work. The pressure came stronger during the Great Depression. Metropolitan merchants could no longer afford expensive rates proposed by settlers. Also, settler production had decreased. Therefore, the state encouraged controlled African production of cash crops to supplement settlers production.

External forces also came into play in the late 1950s under two forms. First, some philanthropic political and citizen groups in England were alarmed by the extreme violence against Africans during the Mau Mau uprising. They pressured metropolitan authorities to grant independence to Kenya. Also, after 1952, more foreign investment flowed into Kenya from British companies. The extent of this capital infiltration in Kenya combined with the rise of an African elite of merchants, politicians, and a nationwide African political movement to reduce settler stronghold of the economy and politics in Kenya. 
Interest of the different political forces in the colonial state. The interests of the colonial state were clearly to maintain the integrity of the colony and to raise enough revenues to build infrastructure, particularly the vital railway to the coast. The state couldn't rely on help from the Colonial Office in London due to British economic problems at the time stemming from decline in hegemonic power, the Great Depression, and W.W.II. Therefore, the policy of the London Colonial Office was to have colonies pay for the cost of their own operation. The colonial state in Kenya relied on revenues from settler agriculture and the income tax to finance infrastructure development and the colonial state apparatus. On governance, the colonial state had a vital interest in preserving the colony itself from disintegration and chaos. In this endeavor the colonial government had to tame down African uprising and political movement, and prevent social breakdown in African reserves.

The settlers had an interest to maintain their economic domination over the colony. They needed protection of the state from competition of metropolitan capital as well as African competition. Because their agriculture was not mechanized, settlers needed to minimize the cost of the inputs of their production. The economic power of settlers and the vitality of their agriculture to the revenues of the colonial state, gave settlers a greater political leverage and power over the colonial government. Therefore, they used the colonial government (1) to confiscate rich agricultural land from Africans, (2) to provide forced African labour for their farms, (3) to impose hut tax as a means to finance infrastructure (such as roads, hospitals, and other the colonial state), (4) to force Africans to join the modern economy by destroying their economic base through confiscation (destocking of African cattle), (5) to close economic competition to Africans through prohibition of cash crop production, denial of trade licenses and credits, and confiscation of cattle as examples. Until after the Mau Mau rebellion in 1952, settlers had almost absolute power in the colony. 
The Africans' interest during the colonial period can be understood as two-fold. Economically, they struggled to gain back the land they had lost for the settlers, to gain access to economic activity (cash crop production, trade, commerce, better paid jobs), and opportunity to the resources of the state (education, health care, sanitation). Politically Africans wanted a better treatment in the society as equal citizens. Also, they wanted to gain access to central organs of the colonial state: the Central Administration and the Legislative Council in Nairobi, and the Provincial Administration. This access necessitated political organization of Africans. As covered earlier, these opportunities were denied to Africans and their interest was played down by the colonial state in favor of the settlers.

Allocation of power in the colonial state. The allocation of political and economic power by the colonial state favored the settlers to the detriment of Africans. The state used coercion to confiscate African land and to force Africans to labour for settlers. In addition, the state blocked access to Africans not only to economic resources (land confiscation, forced labour, slave wages, prohibition to farm cash crops) but also to political institutions that would have allowed them to participate in decision making.

At times, however, the colonial state was caught in a need to secure its own source of revenues and favored African production. For example, following the abolition of forced labour by the ILO and the Great Depression, the colonial state was very indebted. It favored African production of minor cash crops (maize, sisal, pyrethrum) and to some extent some important cash crops such as coffee and tea to supplement declining settler production.

The Swynnerton Plan of cash crop liberalization and land reform sought to preserve the colonial state from disintegration after the devastating Mau Mau rebellion and the widespread African resentment of colonial rule. As Berman (1990) suggests one can understand these reforms as a means of the colonial state to avert its own destruction by the 
growing African political force. The state and settlers, in a desperate move, wanted to lure Africans to a multicultural state dominated by white settlers and Asian traders. The institutional framework designed by the colonial state systematically blocked access of Africans to politics, political organization, and economic opportunity.

Institutional framework in the colonial state. The institutional framework was designed to block the access of Africans to political institutions of the state, political organization and economic resources. Before 1944, all central organizations of the colonial state (Central Administration and Legislative Council in Nairobi) were closed to Africans. African political organization was repressed at the example of the banned $\mathrm{KCA}$, the underground $\mathrm{KAU}$, and the denial of political organization to the ex-askaris. Institutions enacted laws imposing a hut tax on Africans as a means to coerce them to labour for settlers. Also, the same institutions prohibited Africans from producing cash crop, denied trade and commerce licenses to them, imposed slave wages, and controlled African production of competitive commodities.

Until 1944 Central organs of the colonial state (the Central Administration and the Legislative Council) were closed to Africans. Therefore, participation in the political process was denied to them. It is only in 1944 that Eliud Mathu was (Berman 1990) was nominated as the first African representative in the Legislative Council. His contribution opened the way to other African representatives not only in the Legislative Council but also in minor positions in the Central bureaucracy. Mathu initiated many reforms, among others land reform, liberalization of cash crop production to Africans, removal of license restrictions to Africans, free education for all, better wages and improvement of work conditions. Of these initiatives free education, removal of license restrictions, increase in wages and improvement of work conditions were successful. However, the Swynnerton 
Plan reforms drew much from Mathu's initiative, particularly on land reform and cash crop liberalization for Africans.

Africans participated more in the Provincial Administration in rural districts. However, they served mostly as collaborators of provincial administrators. The Provincial Administration as an institution of the colonial state was designed to keep Africans contained in reserves. Their seemingly interest to African welfare was nothing of good will. Their goal, as Berman suggests, was to avoid a societal breakdown in African reserves that could jeopardize the integrity of the colonial state.

Until the Mau Mau rebellion in 1952, political and administrative institutions repressed African political movement and political organization. For example, the KCA was banned in the 1920 s and the KAU was pushed underground existence. Also, the ex-askaris were prevented from forming a political organization, what many had hoped to do after their demobilization.

The Mau Mau insurrection in 1952 represents the gaining of political power by Africans and the widening of their political movement. At this time the underground political movement had reached a nationwide scale with the KAU. Also, the contribution of exaskaris in the socialization of political sentiment was noted by Myrick (1975).

African political movement came as a reaction to land alienation and mistreatment of Africans. Some incidents such as the Mombassa workers strikes gave opportunity to the KAU to recruit more members and to show solidarity of Africans against the oppressing white domination. Also, the nomination of Eliud Mathu as the first African representative to the Legislative Council represented a great change in decision making for Africans. His efforts opened access of Africans to central organizations where most decisions were made. An African political and economic elite emerged after political and economic liberalization following the Mau Mau rebellion in the 1950s (the Swynnerton reforms). This elite dealt directly with metropolitan authorities and capital, and bypassed colonial authorities and the 
settlers. However, land confiscation and cash crop economy had a serious impact on food production starting with the colonial period.

Impact on food production. However, the effect of political struggle and institutional setting in the colony can be understood to have affected food production. On different angles, the consequences are visible. First, Africans were ripped off of the land that provided the main resource for crop cultivation and cattle grazing. Forced labour or squatting in settler farms removed large populations of Africans from subsistence agriculture.

Second, African subsistence economies were systematically destroyed to force them to modern economy. For example, confiscation of cattle (which was the main source of protein and food exchange for the Kamba and Maasai) had a significant impact on food base. Also, forced labour and military service took away large numbers of young men who made the work force in food production for the various tribes.

Third, the significant penetration of capitalist mode of production in the form of cash crop economy profoundly affected food production as more peasants engaged in cash crop production (rather than food crop production) following the Swynnerton reforms. In addition, the content of the Swynnerton Plan does not state specifically any policy that encouraged food production.

Fourth, land reform benefited collaborators of the colonial government and elites. Before colonization ownership of the land was communitarian on tribal basis. With the Swynnerton reform, ownership of land became individual and land redistribution in African reserves provided only small parcels of land to single households. The agricultural return of small parcels of land could not yield enough output for sustained food crop production. Therefore, the expected agricultural output for each small producer couldn't but be small. 


\section{CHAPTER III}

\section{POST-INDEPENDENCE KENYA (1963 - 1990s): POLITICS, ECONOMY, FOOD PRODUCTION AND SUPPLY}

\section{THE KENYATTA ERA (1963-1978)}

In this section, the thesis focuses more on food production and the policies of post colonial Kenya in that area. However, the characteristics of Kenya's politics and economy during this period are investigated. In the previous section, a thorough investigation of colonial Kenya has revealed key characteristics that the political economy of the country inherited from the colonial era. First, the government inherited a paternalistic type of governance dominated by elitism in the state bureaucracy and a strong rule by the head of the state. Second, capitalist penetration created classes even within the peasant populations. A class of wealthy Kenyan businessmen and traders appeared as well as a sizable proletariat. On the peasant side, there appeared a class of wealthy landowners and producers on one hand and a class of landless poor peasants on the other. The income differentials between the 'have' and the 'have not' has grown with years. Third, Kenya inherited a high level state control and intervention in the economy as well as a policy that attracted foreign investment. Fourth, the economy remained mostly a cash crop economy (Duigan and Jackson 1986; Berman 1990; Ochieng 1990) with a sizable manufacturing sector (mostly processing plants for cash crops and foodstuffs owned by Multinational Corporations) 1 (Leys 1975). The influence of MNCs has not just been beneficial to the

1 The important position of MNC investment in Kenya's economy dates from the war years of the 1940s. Great Britain relaxed restrictions on production of manufactured products in the colonies (Berman 
national economies of LDCs (Less Developed Countries) as some may suggest (Gilpin 1987). Although many recognized that MNCS bring some level of capital investment, technology and jobs for LDC economies, they do not necessarily develop these economies. A reason is that all the profits are often expropriated back to their home base country due to the fact that ownership is external. Furthermore, as F. Wambalaba's thesis (Wambalaba 1985) suggests, the impact of MNCs in economic policy and politics of LDCs is significant. Since these companies seek their own profit, it can be understood that they play sometimes a negative influence by distorting the politics and economies of many LDCs. They do not necessarily help policies to move on inward-oriented development priorities to serve the basic domestic needs. Fifth, it was put in evidence in CHAPTER II that the state policies of cash crop production progressively eroded the food production basis of Kenya.

The pre-independence economic policy in Kenya encouraged cash crop production and attracted investment of private capital in the Kenyan economy. This policy led to the explosion of manufacturing plants for processed foods and drinks, tobacco products, shoes, chemicals, cement, refining of petroleum, etc. The post-independence government continued to emphasize on cash crop production for export earnings of the economy (30\% of GDP see data on Figure 6.) The government also emphasized the private sector's role (attraction of multinational corporation investment) in development. Because of the focus of this thesis on food production (negative impact of cash crop economy on food crop production and development strategies stressing food production), the investigation focuses on commercial (cash crop) agriculture and food production policies. Furthermore, because of the specific focus of this thesis on food production, the food production sector is

1990). From the late 1950s the Kenya state encouraged foreign investment in various sectors of industry (cash crops, food processing, textiles' industry, manufacturing, and other). These sectors have provided needed investment capital, technology, and employment to Kenya's economy (Wambalaba 1985). Also, since the late 1950s. Kenya has benefited a larger industrial sector than its neighbors (Tanzania and Uganda.) 
analyzed separately from the commercial agriculture sector of the economy. Basic indicators of Kenya's manufacturing and banking sectors are covered for this period.

Politics and government. Kenya at the independence inherited a centralized government with a single party the KANU. Paternalistic and authoritarian personal rule has characterized governance in Kenya since independence as many studies suggest (Delf 1961; Wiseman 1991; Duignan and Jackson 1986.). The structure of the government has almost remained the same since independence, i.e., a presidential government with a President and a cabinet of ministers, a National Assembly as the legislative body, a Judicial System and web of local governments depending on the central government. The structure of the government after independence reveals the same characteristic of high centralization as was in the colonial era. Jomo Kenyatta ${ }^{2}$ was Kenya's first president and the dominant political figure in the country for almost three decades.

Paternalistic rule and unchallenged personal authority characterized Kenyatta's regime. With the massive support that his charisma and position as "father of the nation" brought to him, he developed an almost monarchical rule as the high government office became dependent on personal loyalty to him. He was intolerant of any form of opposition, and his rule was mildly repressive. ${ }^{3}$ Some events prove that there was significant opposition to

${ }^{2}$ Born in 1890 in Gatundu from the Kikuyu ethnic group, Jomo Kenyatta was educated in mission schools. He joined the East Africa Association (later the Kikuyu Central Association) in 1922. Very active in the KCA, he led a delegation to England in 1929 to press for African interests, especially over land alienation. He spent 15 years in the United Kingdom and returned in 1946 to assume leadership of KAU. Kenyatta was instrumental in extending the support base of KANU nationwide. In 1952 he was arrested and jailed until 1961 for leading the Mau Mau rebellion. In 1962 he was elected in the Legislative Council, and he became prime minister after the victory of KANU in 1962. Kenyatta became Kenya's first elected president in 1963.

3 During Kenyatta's rule there were political assassinations, for example, the deaths of Pio Pinto, Tom Mroya, and M.P.J.M Kariuki (Wa Thiong'o 1983). The underlying issue was the determination of Kenyatta's regime to avoid debate over political and economic choices pursued by the regime. As an example. the author Ngugi wa Thiong'o was arrested and detained by Kenyatta's government for sharp criticism against government paternalism and conformity to Western models. Arap Moi inherited this trend of paternalistic authoritarian rule from Kenyatta's regime. 
Kenyatta's regime as can be proven by the breakaway of Vice President Odinga in 1966 to form the Kenya People's Union ${ }^{4}$. On ideological side Kenyatta declared his dedication to socialist ideals, but taken a capitalist path to development.

The major tenet of Kenyatta's economic and development policy after independence centered on "Kenyanization." Before independence the European and Asians had control over the economy (EIU 1991). The Asians particularly were dominant at every level of the business community (brokers and merchants). The "Kenyanization" policy required that non-citizens be replaced by citizens in all sectors of the economy. This policy sought to secure the interests of Africans by eliminating competition from better trained and financially advantaged European and Asians. One aspect of this policy limited immigration of non-Kenyans, reducing the population of non-native residents. Another aspect of the policy was the takeover by native Kenyans of retail trade and road transport dominated by the Asians. On land distribution policy, a large British economic assistance to Kenya after independence allowed the Kenya government to buy out European settlers' land through the Land Transfer Program to redistribute it to African farmers. "Kenyanization" also involved the development of an educated African elite bourgeoisie and the expansion of education.

However. Heyer et al. (Heyer et al. 1976) have attributed some weaknesses of the Kenyan economy to this program of "Africanization". First, the government sector has grown very fast between the 1960s and 1970s creating a budget burden for the economy. The emergent economies of many former colonies of Africa uniquely produced raw materials and cash crops. Therefore, without a significant industrial sector to provide employment for the educated or the non- educated worker, the government became the major provider of jobs.

4 The KPL was banned in 1969 and its prominent members such as Odinga were detained after the assassination of Tom Mboya by a Kikuyu man brought enmity between the Luo and the Kikuyu (Nelson 1984). The Luo saw his assassination as an ethnic affront. 
Second, underdevelopment of African skill and entrepreneurship have been notorious since the colonial era. The authors conclude that inefficiency arises because the program of "Africanization" has put Africans without enough skills at senior positions throughout the government and private sector. One can refute this argument on the basis that Kenya, more than any other country in sub-Saharan Africa has invested heavily in primary, secondary and university education (Nelson 1984). It would make more sense to confine this argument to technical education, particularly in the manufacturing sector.

Finally, the economy has inherited the inequalities of the old system, i.e., a class division between the "have" and the "have not" as seen earlier. Even though Africans have replaced Europeans and Asians in government and economy, the land transfers for, example, did not benefit all Africans, rather an elite. Because of the emphasis on the industrial sector, inequality was also expressed in the income differentials between the rural and urban incomes as well as between the smallholders and large farms. The authors conclude that Kenya has had a remarkably good growth, but has not had a good run with structural change, employment and income distribution. From the viewpoint of the Dependency School, this argument holds because the Kenyan economy, as many economies of sub-Saharan Africa, are dependent on developed economies and confined to cash crop and raw material production. Addressing the case of the former colonies of West Africa (Amin 1973), Amin accuses structural dependency as a continuation of neocolonialism to serve the needs of the core economies at the expense of the periphery. This situation creates inequalities of development between the core and the periphery at the international level. At the domestic level inequalities of development between rural areas and urban areas can be explained (Amin 1976). So are income inequalities between the elite and the lower classes. Structural dependency causes development policies in the Third World to be outward-oriented rather than inward-oriented. A resulting consequence is maldevelopment of periphery economies (Amin 1990). 
The economy: agricultural sector. Kenya's economy inherited its structure and direction of development from the British during the colonial period that emphasized development of settler production at the neglect of African areas. Therefore, African populations engaged more in subsistence agriculture and livestock raising than in cash crop production. As a direct consequence, until the 1970s, large farms provided the bulk of the export crop production.

Between 1964 and 1972, the Kenyan economy maintained a good level with an averaged GDP growth of $6.5 \%$ (see TABLE III). A comparative examination of Kenya's economic performance in Africa during this period shows that Kenya did better than many African countries. TABLE IV and TABLE V show, however, that in the early 1970s Kenya`s external debt increased from U.S.\$1,475 million in 1977 to U.S.\$5,453 million in 1987. The reason behind these figures is that the economy began confronting external and internal problems that limited the economic growth and caused a negative balance of payments (from a basic balance of $+£ 6.3$ million in 1972 to $-£ 6.3$ million in 1974 as indicated by the data in Figure 9). A worsening balance of trade accompanied the economic decline from -K£62.9 million in 1972 to -K£142.9 million in 1974 as indicated in Figure 10 and Figure 11. 5 The rising inflation and overall deterioration of the terms of trade caused growing negative terms of trade for the Kenyan economy. Domestic pressures from the need to provide social programs, education, a large civil service, and the military added to these factors to worsen the debt.

5 Heyer et al. report that Kenya's economy faired well between 1963 and 1973 and was regarded as an example in Africa with a relatively favorable balance of payments: a basic balance of +2.0 in $1968,+6.3$ in 1972, and -53.1 in 1974 (see Figure 9). The rate of increase of the cost of living was low compared to other African countries, 2 percent per annum during that period. Kenya's total terms of trade deteriorated in 1973 (from 99 in 1970 to 75 in 1974). The country experienced inflation at an annual rate of 15 to 20 per cent. The authors attribute the inflation to (1) the rising of import prices. (2) monetary factors within Kenya. and (3) the rising of food prices to keep up with export parties, and (4) the rising production costs. 
External factors accused by Heyer et al. included the increase in world oil prices following the 1973 Oil crisis, and the subsequent worldwide inflation and recession that increased the interest rates on external borrowing and exacerbated Kenya's external debt. Another element was the collapse of the East African Community (EAC) which previously had allowed Kenya to export a sizable volume of manufactured goods and agricultural products (maize and wheat) to Tanzania and Uganda.

The agricultural sector has played an important role Kenya's economy since the colonial time, especially considering the fact that the country has virtually no natural reserves of mineral. Agriculture has provided the country with stable and substantial export earnings and a base for industrial and commercial growth. Most manufacturing is based on agriculture products. Agriculture has accounted for some 35 to 40 percent of GDP versus 10 to 12 percent from manufacturing, 10 percent from commerce, and 13 to 15 percent from the government sector (see data on Figure 7 and TABLE VI). Agriculture has also provided 75 percent of total employment in Kenya during the period 1964-74 (Heyer et al. 1976). Over $90 \%$ of the population lived in the rural areas between independence and the late 1970s, and depended primarily on agriculture activity for their livelihood. Most recent studies in the 1980s (Nelson 1984) show that agriculture occupies roughly $85 \%$ of the population and was the largest single contributor to the GDP (36\% in the 1970s). The agricultural sector has provided the country with a strong food base at least before 1975 . In the exception of drought years, Kenya has been almost self-sufficient in food during this period. The food self-sufficiency ratio was 1.23 in 1966-68 and 0.94 in 1981-83 (see TABLE VII).

As many developing countries, Kenya has a dual agricultural system: a food production sector and a commercial sector. Peasant farmers constitute the bulk of the farming population in the food production sector, and they produce mainly staple food crops for 
subsistence and little surplus for marketing. ${ }^{6}$ Commercial farms make up the second sector and they produce cash crop for exports, and food crops for local and regional export markets. Within the commercial farms there exist a dualism between small scale and large scale farms. The large scale farmers are located in the former "scheduled areas".

The major strength of Kenya's agricultural sector has been its diversification. As opposed to other countries, Kenya does not rely only on a single kind of cash crop for exports. For example, while Uganda and Tanzania rely mostly on coffee for exports and Ivory Coast on cocoa, Kenya has coffee and tea as major export crops. The main export crops are coffee, tea, sisal, pyrethrum and horticultural products. Other export crops include wattle bark and cashew nuts. Cotton is grown both for local consumption and for exports. Since 1970 agricultural exports have made 70 percent of Kenya's total exports (see Figure 12). On average production of these crops has increased from 1968 on-wards (see Figure 13,14,15,16). The products are commercialized through marketing boards (Kenya Coffee Marketing Board, for example).

However, the agricultural sector has faced many problems since independence as Heyer et al. have outlined. First is its total dependence on the climate. The agricultural map of the country comprises six ecological zones ${ }^{7}$ (see Figure 17). The existence of this ecological setting implies that only 9 percent of Kenya is good agricultural land, 9 percent is

\footnotetext{
${ }^{6}$ It should be noted that small scale and some large scale commercial farms produce also foodstuff products such as maize, sugarcane, and wheat.

${ }^{7}$ Zone I which is less than 1 percent of the total area, is barren and in high altitudes, Zone II is Kenya's highest potential agricultural area. It constitutes 9 percent of Kenya and embraces the bulk of the forests. The agricultural potential of this region is high, especially in the highlands where coffee, tea and pyrethrum are important crops at higher altitudes. Livestock in this region is farmed at lower altitudes. Zone III is a medium potential agricultural area. It covers about 9 percent of Kenya's land area. Most of the large siale farms in these areas produce hybrid maize, wheat and barley. The small scale farms in this region grow cotton, maize, groundnuts, pulses and oilseeds, cashew and coconuts. Livestock is raised also in the region. Zone IV covers about 9 percent of total land area and has marginal agriculture potential. Subsistence crop farming and livestock is the activity of smallholder farmers in the region. Zone V covers 52 pereent of Kenya's total area and is mostly an area of wildlife. Zone VI (Northern Kenya) covers 20 percent of Kenya's total land area. In this region rainfall is sparse and erratic. The region is inhabited by nomadic pastoral people such as the Somali.
} 
marginally suited for agriculture, and 18 percent of the country is better suited for livestock production. The remainder 60 percent of the country is semi-arid or arid and of no significant agricultural use. The second problem, which is due to the structure of Kenya's economy, is that the industrial sector cannot provide agricultural sector with cheap inputs of high quality. As opposed to Asian countries, the industrial sector has been mostly for food processing and cash crop mills, yet has not provided the agricultural sector with manufacturing or repairing agricultural equipment, nor has it succeeded to continually adapting it to the needs of the farmers. This is a serious limitation and implies that the bulk of the farm work requires human energy inputs.

Per capita daily calorie consumption has decreased from 89\% (1966-68) to 86\% (198183) of FAO daily requirement (see TABLE VIII) because of low food intakes and cases of malnutrition in the country. The output of production from labour is not expected to be very high when people do not have enough daily calorie intake. The third problem is that government development programmes in agriculture were relatively low between $1960 \mathrm{~s}$ and early 1970s, for example on irrigation and agricultural research. Another setback facing the agricultural sector is the high population growth rate, which since the colonial period has created a problem of agricultural land scarcity on the already scarce arable land resources of Kenya. High population growth also outmatches the capacity of the present food production sector to meet the demand.

Another issue raised by Heyer et al. is that a large number of subsistence farmers are ignored by development efforts in the country, which reminds colonial policy neglect of subsistence agriculture. Therefore, it shows the negative effect of centralization on two levels. At the first level, total government control over economic activity and centralization of economic activities around key urban centers (especially Nairobi) as a legacy of the colonial period, causes the neglect of rural development. At the second level, the emphasis on large scale producers steals attention and resources away from small scale producers. 
The economy: Government policies. Since the economic liberation of the Swynnerton Plan, the government from 1964 to 1978 had three major economic development programs (Heyer et al, 1976). The First Five Year Development Plan ${ }^{8}$ (1966-70) emphasized on "Kenyanization" of the economy with political equality, redistribution of wealth with land transfers to Africans, and equal opportunities with increased economic growth. This plan encouraged heavy private ownership, and attracted MNCs and other foreign investors. However, the plan did not reduce the class inequalities and income differentials inherited from the colonial period.

The Second Five Year Plan (1970-74) intended for improvement of the first. Particularly, it aimed at overcoming inadequate project preparation, scarcity of Kenyan personnel, insufficient co-ordination, lack of commitment to the plan, exclusion of local authority programmes, and inadequate organization of rural development. The main objective was to direct development to the rural areas where the majority of the poor and subsistence population live.

The Third Five Year Development Plan (1974-1978) was a continuation of the second plan with more emphasis on employment, distribution of income, family planning, rural development. district planning, reorganization of production and trade, environment conservation. However, the Plan was revised because of the worldwide inflation of 1973

8 The objectives were stated thus (Heyer et al. 1976, 36):

The aims of the Government are clear -- to achieve high and growing per capita incomes, equitably distributed, so that all are free from want, disease and exploitation, while at the same time ensuring and guaranteeing:

(1) Political equality in the full Kenyan traditional sense of a right which is independent of economic status and divorced from stern tests and discrimination criteria.

(2) Social justice

(3) Human Dignity including freedom of conscience, and

(4) Equal opportunities, without discrimination by race, tribe, or belief, but also without frejudice to remedying the inequalities inherited from the past. 
caused by the oil shock. The drop of the GDP growth rate from $6.3 \%$ (1973) to $3.6 \%$ (1974) also forced a revision of the Plan. 9

Between year 1964 and 1974, the economy grew at an average 6\% per year GDP growth rate. However, the data in Figure 9 indicate that regardless of the good economic growth, the country's balance of trade was negative with the market outside East Africa ($\mathrm{K} £ 48.5$ million in 1964 and $-\mathrm{K} £ 182.9$ million in 1974 ) while a positive balance was maintained with the East Africa region (K£ 17.0 million in 1964 and $\mathrm{K} £ 35.0$ million in 1974). The terms of trade also declined in extra-territorial trade (from an index of 97 in 1970 to 68 in 1974). The trade deficit with the outside East Africa region (107 in 1964 and 247 in 1974 of import price indexes versus only 103 and 152 export price indexes for the same years in Figure 18 and 19.). It can be unsderstood that the trade deficit was caused by the high cost of imported manufactured products and also the food imports (a total of K£5.867 million worth in 1964 to K£14.157 million in 1973 as indicated in Figure 20). Kenya increased food imports in time to alleviate the problem of droughts. One can generalize without exaggeration that the terms of trade with MDCs of the North are generally unfavorable to dependent economies of the South because the latter rely on commodity exports mostly. The price of these commodities is usually fixed by consumers of the North.

9 The economic strategy devised to stimulate more growth from 1975 on-wards, as contained in Paper No. 4. was aimed at the following goals (Heyer et al. 1976, 40):

1. To keep domestic price increases to no more than half of the increase in import prices.

2. To hold wage increases and increases in other non-import costs of production to less than domestic price increases.

3. To restrain imports.

4. To promote exports.

5. To stimulate production both in substitution for imports and to support exports.

6. To choose policies for our crisis years which in so far as possible reinforce our longer term objectives of promoting growth, employment and an improved distribution of income. 
Kenya's basic balance of payments sharply declined from $+£ 17.3$ million in 1969 to $-£$ 53.1 million in 1974 (see Figure 9). This decline can be considered as a logical result of a sharp increase in government spending on the public sector, especially in education and public service. The decline can be also attributed to the increase in foreign debt to cover energy bills, and imports of machinery and food.

The major government policy toward commercial agriculture has been the provision of services (for example, fertilizer, seed, chemical and farm equipment supply -- see TABLE XXIII) to peasant farmers as well as public infrastructures such as roads. The government invested considerably in the development of cash crop agriculture. Agriculture ranked third in items of government spending after education and infrastructures in the 1960s. 10 This period was characterized by large public expenditures on the agriculture sector to buy back settler farms (75\% of the agricultural budget in 1963-64 and 50\% in 1968-69). Agricultural policy of post-independence Kenya has borrowed colonial characteristics, for example, the characteristics initiated under the Swynnerton Plan. For example, the land reform program was very prominent in the 1960s and the small farm programme was part of the Swynnerton Plan. Other major programmes of the 1960s were the rural water progranme and the range development programme as a determination by the government to commit resources for development in problem areas. The rural water programme was a very significant item in government expenditures to provide rural areas with improved drinking water. The range development programme aimed at improving the standards of living rural populations. A major problem with both programmes was the shortage of funds for maintenance of the infrastructures.

On irrigation, the government undertook a limited large scale irrigation scheme $(8,500$ hectares in 1975) in the Upper and Lower Tana area and the Mwea Tebere regions. Small

10 Tbid. 
scale irrigation was organized under private control in areas growing coffee, sugar and horticulture.

Regardless of the new directions, particularly development of infrastructures for rural areas, the government policies continued their colonial trend: inequalities in smallholder agriculture with the neglect of marginal areas and the neglect of food crop production. Another flaw of agriculture development policy in Kenya is that it overemphasizes large farms at the neglect of small producers.

Another area of government policies is the important and crucial aspect of marketing. Heyer et al. suggest that marketing must be well organized for many reasons. First, it must keep pace with production of agricultural commodities. Second, better organization of marketing lowers the cost of commodity production and the cost of food. Furthermore, a better marketing can increase the foreign exchange earnings from exports by maintaining high standards of products to keep a good reputation in the international market (Ivory Coast cocoa, for example), or by manipulating international markets in the country's favor (Kenya with pyrethrum.) With an improved earning from exports, the welfare of the producers is increased as in the case of Ivory Coast. The authors concluded that the agricultural marketing system in Kenya is well developed in certain respects such as the high quality standards of export crops (coffee, tea and pyrethrum) fixed by the boards.

Many problems are faced by most LDC producers to achieve leverage at the international marketing level: disadvantageous bargaining power in international negotiations particularly in International Commodity Agreement negotiations, disadrantageous at the country's market entry, unsuccessful price or income stabilization policies, insufficient encouragement for export combined with aggressive import substitution policies, and unwillingness to compensate export producers for undervaluation of foreign exchange in the official exchange rate. Heyer et al. found that Kenya suffers from some of these common problems faced by many LDCs in agricultural marketing. 
The market system in Kenya is centralized in control as originated from the colonial period. There are many marketing boards, almost one for each commodity (cash crop or foodstuff). The overall organization of cash crop economy through marketing and produce boards is a strength that provides more organization and more efficiency to this sector than its foodstuff counterpart. In Kenya exports are handled through a variety of marketing boards: ${ }^{11}$ Coffee Marketing Board, Coffee Authority, Tea Board, Kenya Tea Development Authority, Pyrethrum Board, Horticultural Crops Development Authority, Sisal Board, and the Cotton Lint and Seed Marketing Board. Some big international companies with outside sales networks outside such as Brooke Bond and James Finlay and Company also participate in the marketing of cash crops in Kenya.

The system of collection or delivery of export products from the growers depends on whether the latter are large or small. For small growers, collection can be made through cooperatives as in the case of coffee and pyrethrum, or by the authority as in the case of tea. Large growers on the other hand deliver and sometimes process their products on their own.

Coffee is Kenya's most important export crop (32.7\% of total exports in 1964 and $29.2 \%$ in $197+$ as shown in Figure 12.) Coffee is produced by large scale growers as well as a large number of smallholders since the 1970s. Major exports are to United Kingdom, the United States, Sweden, Canada, Italy, West Germany, and the Netherlands. The production and marketing of coffee is overseen by two boards. First is the Coffee

11 Export Marketing Boards in Kenya originated in the 1930s. The goal of their establishment was to improve the marketing of export crops and to get the best possible foreign exchange during the depression. Also, the reader can understand that with the Great Depression, outside market favored the buying of cheap commodities, some of which were produced by African agriculture government-encouraged. Without marketing boards. the settlers could not control the African production.

The common function of these boards is to license growers, to market and process products, and to advise the Ministry of Agriculture, to enforce quotas, to levy taxes and to encourage high standards of production and marketing. For the case of coffee and pyrethrum where Kenya has a good ranking in the international market there are two boards: one responsible for production standards and the other for marketing. 
Marketing Board that has the monopoly over the purchase of the whole coffee produced in Kenya. It sells coffee to exporters in Nairobi. Second is the Coffee Authority that sets the standards of the coffee product. The major problem in the marketing of coffee comes from poor marketing schemes and processing from the smallholder cooperative societies. The problem stems from the fact that in the smallholder areas, coffee cooperatives own and manage their own pulperies. 12 Therefore, keeping high standard of the product becomes problematic because of lower skill and lack of resources. Also the price incentives are not well tuned because of differences from one coffee cooperative to another.

The second major crop is tea which in 1960s was as important in earnings as coffee (12.9\% in 1964 and $18.1 \%$ in 1972.) Tea is an important source of income for smallholders. Production is controlled by the Tea Board of Kenya, but the latter is not responsible for marketing. Instead, tea is processed and marketed by estates and by the Kenya Tea Development Authority that handles smallholder tea production.

In summary export marketing of cash crops is well developed and organized in Kenya. However. because the quality of their product and their marketing efficiency are low, the smallholder cooperatives are a source of weaknesses to the national cash crop marketing.

The economy: industrial and banking sectors. Kenya's industry is centered on agriculture inputs (for example sugarcane industries, canneries, meat industries, coffee and tea mills, etc.). The rest is light industry (such as cement, body products, household products, light steel products) as in most developing countries. The foundations of the industrial sector were laid down in the 1950s. Foreign investment was encouraged significantly after the Swynnerton reforms. Kenya continued to play a central role to serve the countries of East Africa (Uganda and Tanzania) with industrial outputs. Therefore, during the 1960s Kenya embarked in a program of increased industrialization. However, most industries are food

12 In large holder areas, the CMB manages the pulperies. 
processing (canneries and sugar mills), cash crop (coffee and tea mills) or light industries such as clothing, etc. Like the agriculture sector, the industrial sector is dualistic and involves a large proportion of overseas investment. One weakness of this sector is that it is based on capital-intensive products and production methods. There is little proportion of industries of small scale as opposed to Asia. Also, centralization imposes that most of the industries are concentrated in cities, which perpetrates the underdevelopment of rural areas and exacerbates the growth of urban population. The manufacturing sector has contributed on average 11 percent of the total GDP between 1964 and 1974 (see Figure 7).

The commercial and banking sectors are well developed since the early 1960s as a characteristic inherited from the colonial period. As seen earlier, Nairobi was the center of the British East African Protectorate. Therefore, these infrastructures were set to serve the whole region.

Food production for domestic needs. Investigation of the colonial period has revealed that Kenya was self-sufficient in food production and supply during the whole colonial period. Despite poverty and a wide class of landless and poor (40\%), constant hunger and starvation were not a characteristic of Kenyan areas after independence. Most people in the rural areas produced their own food on a family unit basis and supplied cities with foodstuff products (Nelson 1984). 13 Production of maize was increased by the spread of hybrid maize cultivation (maize being the most important staple). On the cash crop sector during the 1960s and 1970s, an argument has been that cash crop production has largely benefited the Kenyan farmer and the peasant by providing more income to households (Kennedy 1987: Kennedy 1989).

13 Most of the statistics used in this part are extracted from (Nelson 1984). 
Until middle of the 1970s the agricultural sector produced enough foodstuffs to satisfy consumption needs of the populations. Between 1964 and 1973, production grew at an annual rate of $4.2 \%$. However, as for the whole economy, the growth rate of food production declined to an annual rate of $2.7 \%$ as the result of the 1974 world recession. Kenya imported foodstuffs and solicited food aid from outside to meet the needs of the population (from 2,000 tons in 1972/73 to 35,000 tons in 1978/79 in TABLE IX). High prices of agricultural inputs combined with erratic weather, production disincentives, inadequate producer prices, and the government's inability to handle bumper crops causing an increase in food imports to alleviate the shortage at the beginning of the 1980s. ${ }^{14}$ Also flawed government policies did not provide enough storage facilities for food surplus. Therefore, food availability in the marginal areas decreased in the early 1980s.

\section{(a) Domestic food supply}

The domestic food supply is varied: maize (the most important staple), wheat, millet, sorghum, rice, beans, potatoes, oilseeds, cotton, and tobacco, sugarcane, cassava, bananas, beef, dairy products, sugar, poultry, eggs, fruit and vegetables. Sweet potatoes, cassava, yams, plantains, millet, sorghums and pulses are of minor volume. In rural areas, production of foodstuff has remained household production for their own consumption and the surplus is sold in the cities.

1. Maize production did not meet the domestic market needs until the mid-1960s. Therefore. the country was forced to import maize (from $\mathrm{Kf} 2.305$ millions worth in 1965 to $\mathrm{K} £ 3.692$ million in 1966 in Figure 20). However, the introduction of hybrid varieties dramatically improved the yield and output of maize production. As a result of this surplus production, the government since 1966 had maintained a strategic stock of maize to meet domestic demands especially urban needs and emergencies such as droughts. In 1976 and

14 Food aid reached 165,000 tons in 1982/83 (see TABLE IX). 
1977 , there was a bumper production of maize following government credit allocation to peasants and farmers. The consequence was a net surplus of maize in the market. However, the government could not buy the bumper excess harvest due to lack of storage facilities. A major disincentive for maize production followed. The farmers cut back in their production from 565,000 tons in $1976,424,000$ tons in 1977 , to 236,000 tons in 1978 (Nelson 1984). However, production slightly increased again in 1980 because of renewed government incentives by credit allocation to farmers.

2. Wheat was introduced by the settlers and was the most important crop after maize. The policy in colonial period was to produce enough wheat to meet Kenya's internal demand and those of Uganda and Tanzania. This goal was attained in 1964 and consequently Kenya became a net exporter of wheat in the late 1960s and early 1970s. However, with the rapid urban population increase in the late 1970 s demand for wheat products rose more rapidly than production requiring wheat imports of 139,400 tons in 1981 through World Bank assistance.

3. Industrial crops consumed locally are sugarcane, cotton. oilseeds, and tobacco. The first commercial sugar mills were introduced in 1922 and the total output of the sugar mills reached 30,000 to 35,000 a year at the independence and largely met domestic demand. With the exception of oilseeds, the other industrial crops consumed internally are not mainly for nutritional use.

4. Meat production until 1970s was mostly done at the household level. In that period, the principal provider of meat at the general market was the parastatal Kenya Meat Commission (KMC.) Commercial and dairy cattle herds in Kenya are mostly of European origin whereas indigenous herds are zebu or mixed breeds. As shown in Figure 21, cattle production declined from 184,700 deliveries in 1969 to 159,500 in 1974 . Sheep and lamb production equally declined. 
Although food production has increased in Kenya from 1964 to the mid-1970s, the supply of food has not followed the same trend due to a high population growth rate. Food availability per capita has declined as shown on the tables. Following the disincentives of 1976-1977, food production has sharply decreased and Kenya has gone from selfsufficient to a net importer of in foodstuffs. This aspect is discussed in the next section.

Marketing and distribution of foodstuffs. The major foodstuffs such as maize and meat are produced at large and small scale, and their marketing is done through boards (for example, the Kenya Meat Commission, the Maize and Produce Board, and the Kenya Dairy Board set up in the 1950s, the Kenya Cooperative Creameries before World War II) as for cash crop products. In most rural areas, the center of local trade is the village market to which the quantities of product are brought periodically.

An important aspect of food production is the marketing and distribution system as stressed by Heyer et al. The crucial role of marketing in the case of foodstuffs is to lower their price and most of all to make the supply of foodstuffs more stable and predictable by an adequate distribution system. Familiar problems of food marketing (common in Third World countries) are unreliable food distribution systems and difficulties in the distribution of inputs. The concerns for a well developed marketing system for food are as equally to lower prices and to meet the needs of the growing agricultural sector than to meet the demand of the growing population.

As covered earlier in this chapter, the food production sector suffers major problems that originate from government neglect of the food production sector, and the poor marketing and distribution systems. The first problem was inherited from the colonial period and has been emphasized during the post colonial era. Cash crop production and industry have been given the most attention by government policy. Because most of the foodstuffs are produced by small producers and households in the rural areas (at the 
exception of maize, wheat, and sugarcane also grown in large scale farms) the income differential with industry has not favored food crop production. It can be understood that the Swynnerton Plan encouraged food production solely to achieve self-sufficiency at the subsistence (household) level to avoid societal breakdown in African reserve areas, but was not given enough emphasis to meet the needs of the fast growing population, particularly in urban areas.

The marketing boards obtain their supplies through private traders, cooperatives, large scale farmers and ranchers. In the case of the Maize and Produce Board and the Wheat Board, agents are appointed by the government. For meat and dairy products, licenses may be required but anyone can be a supplier. The boards distribute the produce through wholesalers and/or through retailers. Wholesalers may be processors as in the case of millets, wheat, and maize. The Kenya Cooperative Creameries and the Kenya Meat Commission do the processing themselves, then distribute to the retailers. The Maize and Produce Board and the Wheat Board distribute through wholesalers and millers.

The marketing boards are supplemented by cooperative marketing organizations that are of two kinds. The first kind is for large farmer cooperatives at national level (for example, Kenya Cooperative Creameries, the Kenya Planters Cooperative Union for coffee, the Horticultural Cooperative Union and the Kenya Framers Association Ltd.) The small farmer cooperatives are organized under pressure from the government to improve quality of the product.

Illegal trade (parallel economy) is another marketing method in Kenya that involves smuggling. Smuggling is most widespread in maize. Other cases include smuggling across the border of sugar, meat and milk in the urban areas. Illegal trade creates inequity and uncertainty of production and consumption as well as it distorts distribution. For the case of foodstuffs, a spread of illegal trade practices proves that government prices are not 
favorable to producers. That is why they go elsewhere to gain more return for their product.

A low cost distribution system for food is very crucial to a country like Kenya with a high population growth, yet a very small arable land. Heyer et al. contend that only with reliable market source of food can one expect people to move from subsistence food production to non-food production in the rural areas. In the cities, reliable food supply, marketing, and distribution are essential to avoid shortages or price hikes that would cause political instability. Also the ability of the distribution system to secure quality and variety is important. This argument is sound because the overemphasis on cash crops has caused the neglect of food crop production. Yet even when food is produced to acceptable quantities, poor distribution system makes it difficult to bring food from the farm to the consumer's table. This observation is particularly applicable to cases when food shortages occurred in marginal areas while the producing regions were flooded with product.

Heyer et al. find that the food marketing system in Kenya has serious shortcomings. The first is that the cost of food is very high (see TABLE XIV). As Kennedy Eileen's study reveals, more than $40 \%$ of household income is spent on food alone. Second, food marketing is unreliable in many areas particularly the marginal land areas. Third, there is tendency in distribution to focus on big urban centers such as Nairobi and Mombassa. The flow of foodstuffs in rural areas tends to be from surplus food producing areas to the west and north (west of Nairobi, Nyanza, Western and Rift provinces), to deficit areas to east (Eastern, Central and Coast provinces.) The marketing of each important staple and foodstuff is discussed in the following.

1. Maize is the most important food crop in the diet of Kenyans as well as beef and milk. Maize is the most widely consumed food in Kenya moreover the dominant staple for low income households. High income groups have heavy biases towards processed foodstuffs. Other tuber plants such as cassava, plantain, millet and sorghums supplement 
maize. Maize marketing faces problems that include inability to supply deficit areas, and mismanagement of national stocks including decisions over exports and imports. For example, acute shortages were experienced in 1961, 1965, and 1971 causing a rise in imports. Other problems have been shortages in problem areas while there was plenty in producing areas. The Maize Produce Board has control over marketing of Kenya's maize. It operated thirty-three storage depots in 1970s. Licensed agents buy the product from producers and deliver it to the nearest depots. From depots the Board delivers maize to millers and wholesalers, and these in turn deliver to retailers who sell maize at a fixed price. One of the most important functions of the Maize Board is to ensure equitable distribution of maize from surplus areas to areas of deficit in Kenya. However, one can suggest that delivery through the state-run Maize Board is inefficient because of administrative inertia and the lack of competition.

One other problem stems from the fact that the local market sales are more efficient and provide cheaper products than the board systems. In addition, illegal black markets are more efficient in providing supply of products at longer distances to marginal areas and abroad.

The most serious problem is the inability of the Board and the Ministry of Agriculture to manage storage facilities. For example, some of the shortages in the 1970 s were due to insufficient storage facilities. In areas of surplus production the pricing policy discourages production and incentives to sell to the Board. For example, the prices of the Maize Produce Board are high compared to their private and local counterparts. In areas of deficit production the price is high which gives incentives to people to produce their own maize. A conclusion can be reached that food pricing in Kenya is a problem. Also inefficiency comes from the licensed agents used by the Board to control the marketing of the produce. That is why illegal marketing in some cases and places has been more successful than marketing organized through government channels. 
2. Beef is a luxury consumer good for many households, ${ }^{15}$ especially in higher income groups. Beef and dairy products account for higher market prices than maize. However, beef is the most important source of protein in Kenya. The pastoral people, the Kamba and Somali, for example, are the most producers of beef and rely on it for their cash income. On the other hand, the Livestock Marketing Division of the Ministry of Agriculture plays an important role in getting supplies from remote producers to the Kenya Meat Commission $(\mathrm{KMC})$. However, the livestock marketing system is still relatively undeveloped particularly in the more remote areas.

The market of beef suffers many problems. Among others is the lack of enough facilities to bring livestock from producers to finishers, processors and consumers. Furthermore, legal monopoly granted to the $\mathrm{KMC}$ in the urban areas kills competition and deprives the customer of choice. Pricing policy adds to legal monopoly of $\mathrm{KMC}$ as another problem for the beef industry. The policy of lower consumer prices benefits the consumers but not the producers.

3. Dairy products in Kenya are of substantial quantities and high quality. There is large consumption of dairy products in the diet of Kenyans; milk and milk products have been traditionally largely consumed in Kenya. The value of dairy products ranks second to beef among major foodstuffs. The most fundamental problem in the marketing of dairy products is the control over dairy marketing by the Kenya Cooperative Creameries that has a monopoly of powers. Another problem as in the case of coffee comes from the smallholder cooperatives which are inefficient. They suffer from similar problems as the smallholders in cash crop production: inadequate training of staff, inadequate control over the officials that leads to mismanagement of funds.

15 See Ghai (Leys 1975). 
4. Sugar is a significant component of the diet in Kenya. It is used not only at the household level, but also industrially for sweet drinks and others. Sugar is mostly produced in Western Kenya and a little at the coast where large scale factories were developed on estate production. The major problems of sugar marketing are: (1) the pricing policy, (2) underutilization of factory capacity, as well as excessive production costs, and (3) inefficiency of the distribution system. Other problems are met in harvesting and transportation of sugarcane because of undeveloped agricultural machinery.

Heyer et al. conclude that although food distribution at the national scale as a whole suffers inefficiency. They acknowledge, however, that informal traditional distribution works better. This observation supports that the distribution of food that take place from private channels functions more efficiently as it is the case for the West Africa region and the rest of the developing world.

In summary Kenya's experience with statutory trading authorities has been unsatisfactory in the food marketing and distribution. The problems are the incidence of pricing problems and the lack of market competition which cause high costs and poor quality of services as well as an inefficient distribution system. Clearly the problem lies not only in low levels of food production but also in the marketing and distribution systems.

Pricing of foodstuffs. In Kenya, the government fixes the price of major foodstuffs at all points of exchange in the market chain (see Figure 22). Also, the government since the 1920s has been involved in setting standards for marketing, for example, the introduction of the grading of maize. The main problems with excessive controls are operational inefficiency and high cost of foodstuffs. High cost may arise in two situations: lack of market competition in the production and marketing, and marketing through the smallholder cooperative. In the first case the lack of competition does not give a wide range of choices 
to the consumer. In the second case smallholder cooperatives alone lack resources to organize efficient marketing at the national level.

There are other problems associated with official price policy, two of which seem of interest. First, big producers because of their market share seriously influence prices regardless of the Produce Boards balancing position towards small producers. Second, prices do not follow supply-demand dynamism, which makes them inadequate sometimes to the consumer (Shapouri et. 1986).

\section{CONTEMPORARY KENYA (1979 - 1990s)}

Starting from 1978, Kenya continued to experience the after shocks of the oil price hikes of 1973 and the following world recession of the 1980s. These were manifested in (1) the imbalance of the terms of trade due to increased energy bills, (2) increased price of manufactured products coupled with the decline of commodity export prices, and (3) increase in food imports to sustain domestic food supply. Especially in 1980, as seen previously, disincentives caused a decline in food production. The structures of Kenya's political economy from 1978 to the present have been laid by the Kenyatta regime.

On the political side, Arap Moi continued with Kenyatta's legacy, and rapidly paved the way for his own rule. In 1982, an aborted coup pushed Moi into a dictatorial rule. On the economic side. the increased indebtedness of the country and the debt crisis (with a debt/export ratio of $342 . \%$ in 1987 , see TABLE XVIII) transformed Kenya from middleincome country in the 1960's and early 1970s to low-income country in the late 1980s and early 1990s even to African standards (Nelson 1984; EIU 1991). Added to its increased population growth (3\% per annum on average), Kenya has gone from a self-sufficient producer of food crops before independence, a moderate importer/exporter of cereals after 
1964 , to become dependent on cereal imports in the 1980s. This part of the chapter will concentrate on these aspects, particularly on food production.

The politics and government. The politics of Kenya and the structures of its government (see Figure 23) have not significantly changed after Jomo Kenyatta's death of (Wiseman 1991). It can be said that the politics have gotten worse, especially with the crisis of governance and declining economic conditions starting from the beginning of the 1980s.

Since independence Daniel Torotich Arap Moi has been a significant figure in postindependence politics. He became President after the death of Kenyatta in 1978. Moi was born in 1924 in Baringo District (from a Kalenjin ethnic group of Kenya) and educated locally. In 1960, he became chairman of KADU, a party that was formed to represent the interests of non-Kikuyu Kenyan Africans. In the pre-independence government he was Minister of Education, then Minister of local government. In 1963 as Kenya became independent with KADU as the main opposition party to KANU led by Kenyatta, Moi was asserted as opposition leader. After KADU merged with the ruling KANU party in 1964, Moi was appointed Minister of Home Affairs. Of all the non-Kikuyu politicians, he became closest to Kenyatta, and in 1966 he became Vice President of the party. In 1967 he became vice-president of the country and leader of government business in parliament. On the death of Kenyatta in 1978, Moi became head of state in what was, to the surprise of some, a peaceful succession.

Constitutionally Moi's succession was a normal procedure and he got the support of many Kikuyu politicians. He asserted his incontestable position when he was unanimously elected leader of KANU the same year he took power. However, Moi lacked the personal charisma that had made the success of Kenyatta and his regime. Therefore, to reinforce his own power base he projected himself as walking on the footsteps of Kenyatta when he pronounced his philosophy as nyayo (meaning 'footsteps'). This strategy was just aimed 
at securing his power base because at the same time the political system became more authoritarian. The arrest and torture of political opponents have since damaged Kenya's reputation on human rights in the 1980s and 1990s, which in the past had been relatively good (Ntanda 1993). For example, the police and the army have been frequently used in Kenya to oppress and repress citizens' demonstrations and by that way have helped to maintain Moi's statusquo.

Because all legal opposition to the government was banned, opponents were forced since to use violent and subversive strategies. In 1982, an attempted coup led by sections of the air force and supported by students and other disaffected groups was put down with difficulty and followed by mass arrests, the disbanding of the air force, and closure of the university. Scholars were arrested and tortured (Wa Thiong'o 1983).

More recently there has been considerable evidence of the existence of a large-scale subversive organization known as Mwakenya (a Swahili acronym for the Union of Nationalists to Liberate Kenya) which appears to have widespread support, although this is impossible to measure. Because of the nature of the Kenyan political system, open opposition to Moi seems doomed. Moi has used key positions in the armed forces, the government, and private sector to control the whole country. Loyal members of his clan have been placed at key management positions, which makes it difficult to challenge his authority.

In foreign relations Moi has followed a pro-Western line as his predecessor, although sensitivity to western criticisms of his record on human rights has sometimes strained relations. A diplomatic tug of war with the United States in 1991 (EIU 1991) is an example. Although not without problems, the Kenyan economy has continued under his leadership to be amongst the strongest in Africa, a factor that underlies the relative stability of the political system and the continuity of the leadership. 
Economic indicators. Kenya's economy has been predominantly agricultural since the colonial time. Sales of cash crops (coffee and tea as main ones) have provided revenues for the economy. However, in the 1990s the economy has been in decline. Kenya's balance of payments worsened after the mid-1970s (see TABLE XV and XVI) and since then the country has accused negative terms of trade and has been locked in debt burden. Indicators of Kenya's economic problems can be revealed in its debt burden. In the 1980s Kenya became one of the most debt-stricken countries in Africa and its status shifted to a low-income country. As indicated by the data on TABLE XVII and TABLE XVIII, the Debt/GDP ratio is alarming for Kenya (342.0\% in 1987). It doesn't give a chance to the country to get out of the disastrous situation.

Many reasons have been responsible for the downfall of the Kenyan economy. First, the oil shock crisis of the 1970 s created a financial burden to Kenya with high energy bills. Second, following the oil crisis, a glut of agricultural commodity exports in the international market and the decline in consumption in developed economies stagnated Kenyan export folio income compared to the increasing import folio (see TABLE XVI). Therefore, the country experienced net trade deficit. Third, Kenya has been since locked in a debt cycle that makes it difficult for the country's economy to pick up because of debt servicing with a debt/export ratio of 342.0 in 1987 (see TABLE XVII and XVIII), a total debt servicing ratio representing $1.8 \%$ of GDP revenues, and $20.6 \%$ of earnings from exports of goods and services (see TABLE XIX).

Kenya's economy has suffered tremendous decline, so has the food import increased as of 1980. Kenya in 1981-83 was listed among countries with sharp food needs (Shapouri et al. 1986). In 1990s, Kenya figures out as part of the hunger belt of Africa, especially with the fast growing population (Hanley 1992A; Hanley 1992B). The next section investigates food production and supply since 1980 . 
Food production for domestic needs

Kenya was an importer and exporter of cereals occasionally since 1964. However, after 1973 Kenya began to experience food problems. Raikes (1991) suggests that Kenya developed a large-scale surplus of cereal and livestock production sector during the colonial period. which generated surplus for the economy from exports (maize mainly) and provided income and food supply for the populations. However, with rapid growth of urbanization and population since independence, food surpluses experienced during colonial period rapidly disappeared. The study suggests that Kenya became a net importer of food in the form of commercial imports (see TABLE XX) and food aid packages mainly from the US PL. 480 programs (see TABLE X and XI). Also the price of foodstuffs compared to other expenses was too high.

Although. during 1969-1976 Kenya was occasionally exporter of cereals to neighboring countries, the period 1979-1984 saw an unprecedented food gap, especially caused by the 1978/79 disincentives and the severe drought of 1984 . Kenya became reliant on food imports and food aid because internal production could not satisfy the needs of the fast growing population. Kenya's food aid dependency index increased from $4.8 \%$ in 1966-68 to $7.4 \%$ in $1981-83$ (see TABLE XII). These numbers clearly depict three periods: the period immediately after independence when Kenya had to import cereals to meet its domestic demands, the period 1971-73 when Kenya produced enough surplus of cereals and became a net exporter since 1969, and the period 1981-83 when the country experienced severe food shortages.

Major reasons for the decline have been outlined by Shapouri et al. as (1) bad weather conditions, (2) lack of incentives to small producers, and (3) government's lack of interest in food production as the major component of the crisis. These reasons strongly intersect with orher studies such as Heyer et al. and Raikes. Both Raikes and Heyer recognize government neglect of the food production sector and lack of incentives to producers in 
marketing and pricing of foodstuffs. Raikes recognizes the vulnerability of Kenya's agriculture to weather conditions due to the climatic and ecological setting of country (only 9\% of the total area are fertile land). In this sense Raikes particularly stresses the lack of efficient and significant irrigation to offset the negative effect of droughts on agriculture production. Raikes has gone further to accuse fast growing population and increased herding as contributing to food shortages and lack of agricultural land. The three studies have accused government neglect of food production in policies. However, Heyer et al. and Raikes have gone further to find roots of the problem in the colonial setting of the country's economy and the subsequent disruption of sustained traditional economies and way of life.

In the following, food production methods and supply in Kenya are examined. Second, the food crisis in Kenya is investigated. Finally, government policies and some issues related to food production in Kenya are addressed.

1. Production and supply. Kenya's food production has largely remained subsistence production done at the village level (Shapouri et al. 1986; Nelson 1984). With the exception of some smallholders and few commercial plantations of maize and sugarcane, mostly food production is done by women in the rural areas. Food products are commercialized in the cities and local markets in the countryside in exchange for cash. The tools have remained mostly traditional as indicated by the degree of mechanization of agriculture (3.6 tractors/1000 hectares) and irrigation (2.7\% of total agricultural land area, see T.ABLE XXI). Although the use of fertilizers and tractors is not necessarily an appropriate indicator of sustainable food production capacity in LDCs, it is, however, a good indicator of the level of modernization of agriculture. It was pointed out earlier that the industrial sector has not helped with tools to facilitate labour and to increase the output. 
Shapouri's et al. study shows a decline in food production and availability as well as the daily per capita calorie availability starting from 1978. TABLE XXII shows that food production per capita has declined from 92.7 in 1985 to $88.3 \%$ in 1987 while TABLE VIII indicates a stagnating calorie deficiency with only $86 \%$ of the average daily requirement. In addition TABLE XIV indicates that on average Kenyans spend $42 \%$ of their household budget on the food they consume.

Food supply should be taken in the present context as the sources of available food in the Kenyan market. There are two sources of food supply: food produced locally and a second category composed of food imports and food aid. Shapouri et al. clearly illustrate that Kenya has become a net importer of food and recipient of food aid in the 1980s. TABLE XIII indicates that on average food aid represented $6.32 \%$ of Kenya's total domestic food production between 1981 and 1983. The consequence of reliance on food imports and food aid to meet domestic needs are the worsening of the debt crisis and a threat to the political stability of Kenya.

2. Understanding the Food crisis in Kenya. In the 1980s and 1990s as the statistics show Kenya faced food shortages and deteriorating food supply reserves. The study by Shapouri et al. found two major reasons to explain the food crisis in many African countries including Kenya. The first point stems from the food production methods used in Kenya. Mostly, production has remained subsistence with the machete and the ax to clear a piece of land for cultivation, and the hoe or the manual plow as the major tools used to till the earth. The use of traditional tools demands intense labour and physical effort from the farmer, which added to the low calorie intake prevents a significant output to satisfy the needs of the fast growing population. Another problem facing the food production sector in Kenya stems from its total dependency on weather conditions. Poorly developed (or non-existent in some areas) irrigation system makes agriculture in Kenya and 
many African countries extremely vulnerable to droughts as opposed to their counterparts in Asia and Latin America.

The second major reason the study supports is that the government has neglected the food production sector by putting too many incentives only on cash crop production. The government has relied too much on food imports and food aid to "fix" the domestic food gap. Many countries in sub-Saharan Africa have inherited cash crop-based economies from colonial legacy. The food production sector has been given scant attention. The consequence for Kenya and the other 10 countries studied in Shapouri et al.'s study is that declining per capita food production has meant falling per capita food availability. A reason is that food aid or food imports cannot fill the food need gap required by the fast growing population. Other failures of government policies include the lack of incentives and credits to women for food production, the lack of storage infrastructures and the poor marketing and distribution systems.

Governments of the region, Kenya's particularly have relied too much on food aid and food imports. As the study suggests the consequences are numerous. Reliance on food imports increases dependency and debt burden. Also, reliance on food inputs from outside in the long run creates disincentives to domestic self-help and affects tastes and patterns of consumption. In Kenya's case, food aid and food imports as the statistics show, have not solved the problem of food gap, instead the problem has exacerbated. The statistics in 1989 and early 1990s show a further decaying situation that contradicts Eileen Kennedy's claims that income from cash crop production has significantly improved the food security of the Kenyan household.

Eileen Kennedy's studies have focused on the effect of cash crop production on health and nutrition in Kenya (Kennedy 1987) and the income nutritional effects of commercialization of agriculture in southeastern Kenya (Kennedy 1989). In the first study, the author acknowledges that increased household income from commercial agriculture can 
alleviate the hunger problem because more income to the household means more buying power for the food. Therefore, more food security and calorie intake for children are expected. The second study has found out the children of families working in the sugarcane industry in southern Kenya were malnourished on average. Her conclusion entails a small flaw about the relationship between income and food sufficiency in Kenya. First, she seems to ignore the cost of food compared to other living expenses. TABLE XIV shows that food-related expenditures for Kenyans represented on the minimum $40 \%$ of the household income, which is quite high. It does not leave the latitude to even those employed to save enough to satisfy other basic needs such as health and education. Furthermore, with such high cost of food, domestic savings cannot be accomplished. Second, Eileen seems to concentrate her study too much on food availability with the capacity to buy food, instead of basing her conclusion on the food supply per capita. Although agriculture production has increased as a whole in Kenya from 1985 to 1987 (see TABLE XXII), food production per capita on the contrary has sharply declined from 1985 (92.7) to 1987 (88.3). Furthermore, Kenya is below the calorie requirement of FAO (only $86 \%$ of the daily calorie intake requirement). Third, the "proletarianization" of peasants have made them particularly vulnerable to international shifts in the prices of agricultural commodities. Instead of food security for the household, reliance on cash crop economy makes peasants dependent on urban centers for their self-help in basic needs.

Another issue is the government dependency on food aid ${ }^{16}$ or food imports to the neglect of more efficient policies to encourage food production (Shapouri 1986; Raikes 1991). As will be discussed in CHAPTER IV and expanded in CHAPTER V, more fruitful and sustainable policy orientations to achieve self-help in food production and

16 Kenya is a recipient of food aid from EEC, World Bank and USAID (Raikes 1991). However, World Bank and USAID are Kenya 's major donors of food aid. For example, food aid increased in Kenya in 1984 not only due to drought. The preferential strategic importance of Kenya to the US interests in the region. 
supply in Kenya (and by extension many countries of sub-Saharan Africa experiencing food crisis) are the following. First is the shift of emphasis from cash crop production by provision of incentives to men for food production and the empowerment of women. Second, curtailing of food imports needs to be implemented to force people to produce more food domestically. Third, improving marketing, distribution and pricing of foodstuffs is necessary to improve output levels. Fourth, re-organization and development of rural economies around food production activity when applicable will help rural areas and retain people there. Raikes' arguments are discussed in the following as alternative explanations for Kenya's food crisis in the 1990s.

Raikes has identified five major reasons to explain the food problems in Kenya. First, he accuses the unequal distribution of fertile and cultivable land in Kenya. Kenya's fertile and high-rainfall land in the center and west covers only $20 \%$ of the whole land whereas arid or semi-desert areas cover $80 \%$ in the east, north and south. The Kitui District, for example, is a dry area that faces severe food shortages. Excess of cattle grazing has added to arid soil to cause food shortages. Although cattle are the most economical and nutritional resource in the region, it cannot solve the food problems in time of shortages. Another region. the North-Eastern Province inhabited by the Somali pastoralists is more arid and faces food shortages as well. The pastoralists have practiced some sort of irrigation. However, with droughts, water shortages prevent the very basic traditional irrigation from having any significant beneficial effect for crops. Other elements such as the large-scale Bura irrigation threatens the survival of the subsistence methods of these pastoralists. Better irrigation and food distribution can offset possibilities of food shortages due to bad weather in the sense that food surplus from agriculture-rich regions could be efficiently distributed to marginal areas. In addition, a better distribution system could provide cheaper meat from livestock-rich areas (Kamba district and the nomadic pastoralist regions) to the other areas. 
Second, fast population growth has contributed to shortage of land and shortage of food even in areas of fertile land and high agriculture output. In the Kisii District located in the fertile highlands region, for example, the problem is not arid soil, but overcrowding which causes landlessness and poverty. Kisii has the highest rural population density in the country ( 400 per square $\mathrm{km}$ ) and the highest population growth rate in Kenya (4 percent per annum.) The food is available but many families cannot afford it because it is very expensive compared to the household income. For those who have small plots of land they cannot produce enough to meet the needs of the family. Kisii, since colonial time, has been a major grower of cash-crops such as coffee, tea, sugar-cane, sweet bananas, fruits and vegetables. However, studies have shown that increased earnings from cash crops did not mean better nutrition, in particular for children in the Kisii District. Those studies, for example, Kennedy Elaine's study of the nutritional effect of sugar-cane and cash crop production on family's food security (Kennedy 1987; Kennedy 1989) showed that peasants household increased to attainable food security levels, but the kids were malnourished. Similarly, population growth in the cities, especially urban middle class population has increased the demand for more food. It can be supported that population growth is not always a problem if better policies for food production are put in place, because they could take advantage of cheap and abundant labour to produce more food for urban populations. 17

17 Many policy advisers in developed economies have pointed the finger at population growth in Third World countries as the major cause for widespread hunger and destruction of the environment. Therefore, they have pushed LDCs for more population control (Barbara Crossette, Sept. 4, 1994. U.N. Meeting Facing Angry Debate on Population. The New York Times, September 4, 1994.pp. 1,4.).

The author of this thesis contends that population growth is not always a problem. Population growth is indeed a problem when the country does not objectively have any means to produce enough food for its populations. This thesis accuses the neglect of food production in government policies and economic experts advising as why hunger is spreading in Africa. The supporting fact for this argument is that there is much land, and cheap labour that is abundant even more because the industrial sector has not yet developed enough to absorb the excess labour. 
Third, according to Raikes, colonization brought an abrupt disruption of societies, rinderpest, famine, etc., and the alienation of African land to the benefit of the settlers. However, even after independence the problem has remained. The class of rich peasant and land owners have the biggest chunks of land while the remainder of the population are either landless or have a very small portion of land that does not produce much output. For example, in fertile highlands, increased population has led to fragmentation of already small farms with reduced output potential or to landlessness. The argument of colonial disruption of the African way of life is sound. Although economic independence of African countries is still questionable, history and colonization, however, cannot be blamed forever for African ills while forgetting the important contribution of flawed government policies and mismanagement on the economic and political crises within independent African countries.

Fourth, another problem that came with independence is the increase in herd populations with improved breeding and animal disease control. As a result, pastoralists have had growing herd populations yet inadequate rainfall and grazing resources. Therefore, peasants on the edges of cropping areas have been pushed into the pastoral

Siding with Amin (1973) and other scholars (Davidson, 1989) of the "reformed" Dependency School, the present research supports that developed economies have increasingly put emphasis on the Green Revolution in the 1970s not necessarily with the states purpose to "help these countries rip fully the benefit of the niche by specializing in what they produce better -- that is agriculture". Rather, they have encouraged more cash crop production to make the prices of these commodities fall in the international market. particularly after results of cartel-like movements such as the oil crisis of 1973 have proved to be able to shake the world economy or to make consumers of the North dependent on producers of the South. The sharp decline in the price of these commodities as of the end of the 1970s can justify this logic conclusion. The contradiction of the Green Revolution movement is clear: it has encouraged agriculture to produce cash crop while neglecting food production that is primary to sustain human life.

Addressing the issue of environmental degradation, extensive cultivation with forest burning and firewood consumption have been accused as the main causes of deforestation which in turn cause soil erosion. This premise seems sound. However, the real threat of deforestation, destruction of animal species' habitat. and effect on global warming comes from the need for hard wood products in MDCs, particularly Europe. The peasants in Latin America, Africa and Asia are not first responsible of the cutting down of old growth forests they are unjustly accused of. Except in some cases such as Thailand, wood exports mostly henefit consumers of the MDCs, MNCs, and the elites in LDCs even when revenues from these exports seem to provide foreign exchange and jobs for local economies. 
margins and face hunger. This thesis differs with Raikes in that the problem with grazing is not due to the explosion in the number of herd heads. Rather, traditional livestock farming practices of the pastoralists and grazing can no longer be sustained with fast population growth. If grazing grass is cultivated as it is done in MDCs the problem of agricultural land degradation due to grazing can be solved. This would imply a change in the lifestyle of nomadic pastoralists from nomadic to sedentary and from extensive to intensive grazing.

Fifth, in the fertile highlands, the adoption of cash-crop production for export and the government's total emphasis on this type of agriculture has caused a decline of food production for domestic consumption. A solution to this problem seems to encourage food production at home while curtailing the imports of food from developed economies. A problem with this solution would come from the opposition of MDCs (US, EEC, Canada, Australia, Japan and others) who benefit politically or economically from exports of cheap foodstuffs to LDCs. Expanding on this line, structural setting in the world market such as the reduction of trade tariffs imposed by recent GATT agreements (Uruguay Round) impose an "open door" policy to powerless LDCs as a prerequisite for obtaining loans from the IMF. These countries would face a dilemma: curtail food imports from the MDCs to develop their own food production sector and face trade sanctions or cutoff of aid, or continue to import food and become dependent on MDCs to feed themselves. This thesis supports to choose the lesser of the two devils, that is, the first strategy because in the long run domestic self-help in food production will be achieved as a benefit.

Sixth, production methods have remained subsistence methods for small producers in general and peasants particularly. In addition, the role of food production has been left to women alone to feed the family and to take care of the household while the men have concentrated only on cash crops or off-farm jobs. Therefore, men's contribution to food production has faded because they no longer help women in this task as they used to do in 
pre-colonial times. Added to diversion of male labour from food production, poverty has caused dispossession in certain areas. For example, privatization of group ranches in Maasailand has led to the selling of land by pastoralists. In the Narok District, the hunter gatherer Okiek sell their land to the Kipsigis and Gusii farmers to earn cash to pay debts, therefore, dispossess their families (women and children) from the main input source for food crops.

Finally Raikes has accused government policies of causing a decline in food production: inefficient, capital intensive and environmentally non-sustainable projects such as the Bura irrigation scheme; inefficient distribution of food crops, flawed marketing policies; too much reliance on food aid and food imports which cut the incentives for selfhelp domestically; the lack of infrastructures for storage and distribution of foodstuffs. In the case of Kenya, for example, there have been food shortages following very big harvests because of lack of storage, and food shortages have been experienced in problem areas while the rest of the country was having plenty of food.) This area falls in the sphere of policy implementation and will be expanded in CHAPTER $V$ with a proposal of new strategies to boost food production.

Other government policies involve expensive large scale irrigation schemes that create environmental damage and add to the debt of the country. One of these schemes is the MwealTabere Rice Scheme that was practiced by the government on large scale. It is a large scale scheme for production of irrigated rice on peasant plots through block-farming and under the supervision of a manager. The plots are contiguous rectangular blocks so that mechanized operations can be possible. This scheme is responsible of $70 \%$ of the total rice produced in Kenya for official market. The scheme undoubtedly has helped to increase production of rice. However, it is shown that the women who work in those rice schemes lack food security for their families, therefore, malnutrition has not been curbed for those families as hoped. The Bura irrigation system is based on the same principle as the Mwea 
Rice Scheme. However, like many big irrigation systems in Africa, it is capital intensive and may not yield the benefits expected.

The Bura large scale irrigation scheme has been granted financial support initially by the ACP (African, Caribbean and Pacific countries group). 18 Of all ACP members, Kenya is the largest borrower from the European Investment Bank. The Government has been granted a number of agricultural projects among which the Bura irrigation scheme on the Tana River, of which the EDF (European Development Fund) is a part-financier together with others. However, delays in construction and other technical problems have threatened the project. First, production of hydroelectricity upstream has rendered unpredictable the flow of the river and level, which threatens the viability of that irrigation system. Another, a social problem involves local Somali pastoralists who used the riverside land for grazing during the dry season and stock water. With the irrigation system, the water is retained upstream by dams, cutting its use to the pastoralists downstream. The problems mentioned have discouraged some donors involved in the Bura irrigation project.

Another project has been The Machachos District Development Programme. This programme has been directed to improving the marketing system for cotton. Other funds have gone to rural infrastructures, credit to farmers, food crops, water and health.

Raikes has also accused Western multilateral institutions and donor organizations of supporting ill-thought projects; he gave two examples. The first is the World Bank Integrated Agriculture Development Programme in Kenya (IADP) in the late 1970s, which turned to have a very negative impact on small farmers. The project worked in a sense that

18 The ACP is African, Caribbean and Pacific countries group (Raikes 1991). These countries are tied to EEC through the Lome Convention signed in 1975. The convention is agreed at five-year interval and covers aid and trade. The European Development Fund (EDF) is the account out of which the project aid agreed under the Lome Convention is funded. The group is based around ex-colonial possessions of the member states of the EEC but has spread to include other independent countries in sub-Saharan Africa. EEC aid to ACP can be divided in two major parts. One part goes to Third World Countries that are not part of ACP. The larger portion of this aid is composed of grants for items other than food. This accounts for 40$50 \%$ of the total aid. The rest of it is made of loans, capital spending, and administrative costs. Food aid is given entirely on grant basis. 
it provided the peasants in small co-operative unions with credit to buy farm equipment and fertilizers. However, the cost of these imported products was high and not affordable in the long run by the unions. In particular, diminishing returns of agriculture sales since the late 1970s were due to a sharp decline agricultural commodities prices in the international market. Several co-operative unions went bankrupt. Although the program was initially meant to assist 'weak' co-operatives with credit, it left so many deeply indebted as to be virtually non-operational. Peasants became reluctant to sell their products to co-operatives in a fear that the proceeds would be taken for debt payment. In the following, many peasants became unwilling to take loans afterwards because of what happened. A direct consequence was the lack of incentives to food production that the country experienced in the late 1970s.

Another flawed policy is the food aid policy of the World Bank and USAID towards Kenya: both are the country's major food and aid donors. Important food reform policy in Kenya concentrated on channeling food aid and other resources to the National Cereals and Produce Board through a government and multi-donor committee. ${ }^{19}$ NC\&PB has monopoly over pricing controls. Private traders are licensed in some areas, but most producers have to sell to NC\&PB except for a small amount in the local market. This policy has encouraged contraband and hikes of prices in the market. For some it has created disincentives because producers are paid moths late by the government. The NC\&PB deducts money from sales to pay back credits from donors to alleviate the pressure. By early 1988, in return to substantial EEC aid payments, the Kenyan Government had formally agreed to privatize part of domestic cereals' market.

Raikes concludes that severe food shortages in the future seem inevitable unless the offfarm jobs are increased drastically. However, he acknowledges that with present economic conditions, food is non-affordable to many because of its high cost.

19 This policy is similar to EEC policy. 


\section{Conclusions drawn from the three studies (Heyer et al., Shapouri et al., and Raikes)}

The problems raised by the three studies are strikingly similar (see TABLE XXIV). In particular, all three have accused (1) government neglect of the food production sector, (2) flawed government policies, and (3) the impact of structural setting of the world economy and its fluctuations on Kenya's economy. Particularly Heyer et al. and Raikes' findings have very much in common. Since both studies have been done almost twenty years apart, it can be concluded in the present research that not much has been done since the Kenyatta era to improve the food production sector in Kenya significantly. Other conclusion is that the colonial characteristics of Kenya still contribute a major part in the current problems faced by the country.

Amin's critique of development failure in sub-Saharan African countries and the exploitation (through international economic setting and institutions) of these nations by developed nations has also insisted on similar points (Amin 1990). Davidson (1989) has demonstrated that a constant neglect of the food production sector in most sub-Saharan African countries is a result of the overemphasis on cash crop production. This trend is a legacy of the colonial setting of these economies. These economies were designed to serve the needs of the former metropolises in raw materials and agriculture commodities such as cocoa, tea, coffee and other. Raikes joins Davidson when he goes further than the other two studies to focus on the structure of Kenya's economy as a dependent economy setup for cash crop exports. Investigation of colonial Kenya proved in CHAPTER II that the current structure of the country's economy as a cash crop exporter was set up during the colonial period and has remained so for most countries in the region. Amin suggests the same thing when he denounces cash crop economies in West Africa as a continuation of neo-colonialism (Amin 1973). 
While the other two studies have focused much on current leadership's responsibility in the African food crisis, Raikes and Amin, however, have dwelled much on blaming colonization of distorting the traditional economies of African countries. It is worth considering that historical analysis, although it should be considered in the search of solutions for deeply rooted social problems, should not preclude responsibilities of current policies on the problem. This remark applies much for the food crisis in Africa. This thesis acknowledges that blame should be put on the colonial setting of sub-Saharan African economies and the negative effects of colonization. However, dwelling too much on those may lead to neglect the important fact that African leadership has not done much to solve the problem due to mismanagement and lack of skill, particularly when other colonized regions such as South East Asia and Latin America, are developing at fast speed in the 1990s. In his theory of capitalist imperialism, Lenin recognized as Karl Marx the role of capitalism in developing the world, yet unevenly. Also it has been widely recognized in Development Economics and Modernization Theory that capitalism progressively destroys traditional methods of production, hence the way of life, to replace it with capitalist mode of production and lifestyles.

Of the three studies only Raikes has addressed population growth as a serious issue that causes food shortages. This research sides with Raikes in the argument that food production should try to match population growth to avoid food shortages. However, contention can be raised that population growth is not necessarily a problem when the potentiality to produce food is dormant and has not been exhausted yet. What this means is that government policy, if it had encouraged food production the food crisis should have been lessened. Some may contend that more population depletes the environment. 20 This

20 U.N. Meeting Facing Angry Debate on Population. The New York Times, September 4, 1994. pp. 1.4. (Barbara Crossette. Sept. 4 1994). The recent UN population conference has unanimously recognized population growth as a universal problem with the fact that in 20 years 2 billion people have been adjed to the planet. However, the author suggests that not much agreement has been reached on the implications of population growth for natural resources. Many in the South accuse developed nations to 
assertion suites more to cases when the use of the environment is done extensively rather than intensively as the new environmental protection trend dictates in developed economies. In addition, in a country such as Kenya where industrialization has not significantly picked up yet, the abundant and cheap labour should be redirected to food production hoping that with development of the industrial sector the surplus labour will be used in manufacturing and service industries.

Another argument against blanket population control is that natural regulation of population (diseases) may reduce the population to irreversible low if the growth of population falls below levels that are not sustainable for the given country. For example, Sweden in the past encouraged excessive birth controls and found themselves forced to import more immigrant labour and to encourage births because the population had become too old. It is agreed, however, that some level of population control is necessary, particularly in the cities where people are without jobs and cannot afford a large family anymore. This remark calls for supporting the point that the first two issues raised in this section (government neglect of the food production sector and flawed policies) and to some

point the finger at poor populations in LDCs for responsibility in environmental degradation. In reality it is more the consumer in the North who is responsible for depletion of natural resources because of overconsumption. Barbara writes:

"Can the earth sustain its present rate of population growth? Who is to blame for the destruction of natural resources. profligate consumers in industrial nations or desperate poor in overcrowded, underdeveloped countries who strip the land of vegetation in order to survive?"

The present thesis supports that the major concern with population growth is not destruction of the environment per se in the South, rather it is the food supply and production to meet the needs of this population that worries policy makers. It is here that the neglect of food production by many governments is a serious problem. If more food was produced in LDCs, neither LDCs nor MDCs would be worried so much about "too many mouths to feed"; the problem would have been lessened at least a bit.

The responsibility bears on everyone because even Western policy advisers have indirectly caused the neglect of food production in LDCs by pushing these countries into more cash crop production. Population control is needed in the long term because even in industrial nations, the outputs of mechanized agriculture have increasingly accused diminishing returns because of the overuse of soils and pollution. Therefore, supply of cheap foodstuffs from the North to the fast growing populations of the South is not sustainable in the long term. 
extent the structural setting of the world economy and its institutions. These are real issues to consider in the search for solutions to the African food crisis in the 1990s.

None of the studies cited in this section has addressed two issues of secondary importance but worth addressing in the search for causes of the food crisis in Kenya: (1) the change in food consumption habits and tastes of urban populations, and (2) the impact of the Green Revolution on self-help in food production. Addressing the first point, Heyer et al. have only alluded to the issue when they pointed out that as income grows, middle class populations in the cities tend to buy more expensive foods. In the case of Kenya, they have suggested that middle class families tend to buy imported cereals (rice, farina, and other), wheat products, and expensive meat versus consuming local staples such as corn (which enters as the main staple in the menu of the average Kenyan) and root crops. Also, the psychology of tasting "products from developed countries" is not to be taken for granted when considered the critique that many have addressed to the Modernization School. That is, the reality that colonization has indirectly misled many in the colonies to think that products from the metropolis are necessarily of superior quality, good for their needs, therefore, a necessity to acquire for raising one's social status.

It can be then suggested that penetration of the market by these "new foods," particularly easy-to-cook ones (rice and wheat products) has had significant adverse impact on the demand for local staples such as root and tuber crops. With the lessening of demand for the latter, it can be forecast based on the supply-demand dynamics that a lack of incentives to produce local staples follow. Also, it is widely accepted that capitalist market penetration not only affects traditional ways of life and production methods, but it also increases the tendency for new tastes.

The second issue is the impact of the Green Revolution of the 1960s and 1970s. The Green Revolution introduced the use of fertilizers in agriculture and high yield species. In the food crop sector notably it introduced high yield species of corn and wheat particularly. 
However, this thesis contends (see footnote in this chapter) that most of the policies have leaned on increasing the yield of cash crop production per hectare with the introduction of chemical fertilizers, insecticides, as well as high yield species of cocoa, coffee, tea, palm trees and other. The failure of the Green Revolution to provide self-help in food production for many sub-Saharan African countries in the 1990s justifies why this thesis concludes more harshly that these policies were not oriented towards food production specifically.

Rather, they were more targeted towards increasing the yield of cash crops. Therefore, drawing from the fact that food production neglect by most countries in subSaharan Africa has been continued while Western economic advisers have recommended growing more cash crop to earn foreign exchange, it is justified to conclude that the Green Revolution's apparent success in the 1970s was just a growing cancer for the food production sector of the economies of sub-Saharan Africa. It can be thought based on this argument that the Green Revolution was engineered by developed economies to glut the international market with cash crops so that their prices will drop down as dictated by supply-demand.

\section{CONCLUSIONS TO DRAW FROM COLONIAL LEGACY}

From this lengthy investigation on Kenya it can be concluded that the country has inherited important characteristics from the colonial period that still persist at all levels of the political economy of the country: governance and politics, the economy and food production in particular.

On governance and politics the country inherited elitism, ethnic politics and paternalistic authoritarian rule (combined with personal rule in the hands of the President) as the regimes of Kenyatta and Moi have proved. These were the key characteristics of the Central and Provincial Administration during the colonial period. 
TABLE XXIV

CAUSES OF THE FOOD CRISIS IN KENYA

\begin{tabular}{|c|c|c|c|c|c|}
\hline $\begin{array}{l}\text { Cause for food crisis in } \\
\text { Kenya }\end{array}$ & $\begin{array}{c}\text { Heyer et } \\
\text { al. }\end{array}$ & $\begin{array}{c}\text { Shapouri } \\
\text { et al. }\end{array}$ & Raikes & $\overline{\text { Amin }}$ & " Davidson \\
\hline $\begin{array}{l}\text { 1. Structure of Kenya's } \\
\text { economy as agriculture and } \\
\text { commodity exporter }\end{array}$ & NA & $\mathrm{NA}$ & A & $\begin{array}{l}\quad \text { A } \\
\text { (Dependency } \\
\text { applied to Africa in } \\
\text { general) }\end{array}$ & $\begin{array}{l}\quad \text { A } \\
\text { (applied to } \\
\text { Africa in } \\
\text { general) }\end{array}$ \\
\hline $\begin{array}{l}\text { 2. Colonial disruption of } \\
\text { native economies and way of } \\
\text { life }\end{array}$ & NA & NA & $\bar{A}$ & \begin{tabular}{l}
\multicolumn{1}{c}{ A } \\
(Underdevelopment \\
applied to Africa in \\
general)
\end{tabular} & I \\
\hline $\begin{array}{l}\text { 3. Government neglect of } \\
\text { food production sector to } \\
\text { emphasis on cash crops }\end{array}$ & $\bar{A}$ & $\bar{A}$ & $\bar{A}$ & \begin{tabular}{l}
\multicolumn{1}{c}{ A } \\
(Maldevelopment \\
applied to Africa in \\
general)
\end{tabular} & $\mathrm{I}$ \\
\hline $\begin{array}{l}\text { 4. Flawed government } \\
\text { policies (poor production } \\
\text { methods and technology, } \\
\text { marketing, distribution, } \\
\text { pricing) }\end{array}$ & \begin{tabular}{|l|}
\multicolumn{1}{c|}{ A } \\
(poor \\
production \\
methods and \\
technology) \\
\end{tabular} & $\bar{A}$ & $\mathrm{~A}$ & \begin{tabular}{l}
\multicolumn{1}{c}{ A } \\
(Maldevelopment \\
applied to Africa in \\
general)
\end{tabular} & $\mathrm{NA}$ \\
\hline $\begin{array}{l}\text { 5. Natural ecology of } \\
\text { Kenya }\end{array}$ & $\mathrm{NA}$ & $\overline{\mathrm{A}}$ & $\bar{A}$ & $\overline{\mathrm{NA}}$ & $\overline{\mathrm{NA}}$ \\
\hline 6. Population growth & NA & $\mathrm{NA}$ & $\overline{\mathrm{A}}$ & $\mathrm{NA}$ & $\mathrm{NA}$ \\
\hline $\begin{array}{l}\text { 7. Impact of Green } \\
\text { Revolution policies }\end{array}$ & $\mathrm{NA}$ & $\mathrm{NA}$ & NA & $\bar{I}$ & $\bar{I}$ \\
\hline $\begin{array}{l}\text { 8. Change in consumption } \\
\text { habits and tastes due to } \\
\text { market penetration and new } \\
\text { products }\end{array}$ & $\mathrm{NA}$ & $\mathrm{NA}$ & $\mathrm{NA}$ & I & $\overline{\mathrm{NA}}$ \\
\hline $\begin{array}{l}\text { 9. Structural barriers set by } \\
\text { international economic } \\
\text { institutions which forces food } \\
\text { imports (GATT. CAP \& US } \\
\text { agriculture policies), impact } \\
\text { of international market } \\
\text { fluctuations }\end{array}$ & $\bar{I}$ & $\bar{I}$ & $\bar{I}$ & \begin{tabular}{l}
\multicolumn{1}{c}{ A } \\
(Unequal \\
development and \\
structural \\
dependency applied \\
to Africa)
\end{tabular} & $\bar{A}$ \\
\hline
\end{tabular}

Legend: A (addressed), NA (not addressed specifically), I (implied)

The Kikuyu have continued to be very influential in politics and the political rivalry between Kikuyu and Luo on one hand and the minority ethnic groups versus Kikuyu and 
Luo on the other. Also during Moi's period a new rivalry has risen between his ethnic group (the Kalenjin) and other groups particularly the influential Kikuyu group. The reader can understand that these new rivalries mostly come from the crisis of control and corruption in the government and state institutions. The Kalenjin group has been favored by the regime to control key positions in the army, air force, police and administration (Wa Thiong'o 1983). Repression has continued with Arap Moi's detention of political prisoners and scores of human rights violations as well as repression of criticism of the government. The government has continued to play a central role in the political economy of the country with centralization, control, and attraction of foreign investment by the MNCs in the economy.

On the economic side, the country inherited a dependent economy based on cash crop exports. It also inherited significant level of capital investment by MNCs in the industrial sector. On the agricultural sector particularly, cash crop production has increased, encouraged and subsidized by the government. Two immediate consequences have emerged. First is the weakness and dependence of the economy on cash crop commodity exports the price of which has declined since 1975, therefore, an ever increasing trade deficit. Second, there has been a decline in food production and quality per capita that is exacerbated by the fast growing population, scarcity of arable land and droughts. As a consequence. Kenya has become very reliant on food aid and food imports that add to the worsening of its debt crisis in the 1990s. This combination of factors places the country among the worse indebted of the continent and low income to world standards in the 1990 s.

Of particular importance, some elements have been found in the research that prove (1) the emphasis of government agricultural policies on cash crop production since colonial era and, (2) the growing food crisis in Kenya because of government neglect, flawed policies and economic dependency. Particularly, the marketing, distribution and pricing policies of 
food production have been detrimental to Kenya's self-help in food supply while the private and traditional market and distribution systems for foodstuffs have proved to be more efficient in feeding the populations. That little research has been institutionalized in the food production sector is also a striking clue to explain government neglect. The most significant research endeavor accomplished in food production involved the production of hybrid maize and hybrid cattle species in the late 1950s and early 1960 s.

Mostly, the task of feeding the populations has been left to smallholder and peasant producers (at the exception of maize that is also produced by large scale farmers). However, the throughput of peasant production, which employs traditional methods of cultivation and lacks better organization, cannot satisfy the needs of Kenya's fast growing population if considered that the country has also been for the past decade the host of thousands or refugees from neighboring countries and from the Horn of Africa (Somalia and Ethiopia.)

The characteristics of the political economy of Kenya, the subsequent food and agrarian crisis of and economic decline in the 1980-90s reinforce the argument that most economies of sub-Saharan Africa have inherited a colonial setting and framework which (since they have continued with neo-colonialism and economic dependency on the West) plunge them in economic decay, particularly food crisis in the 1990 s.

The studies of Heyer et al. (1976), Shapouri et al. (1986), and Raikes (1991) have been done almost one decade apart from one to the other at periods that have been marked by particular conditions in the international economy and the economies of African countries. The 1970 s witnessed the after-shocks of the oil crisis of 1973 and its consequences including in particular the decline of prices of agriculture commodities in the world market and the worsening of terms of trade for African countries. The 1980s witnessed a general world recession and growing food crisis and economic decline in Africa. In the 1990s, food and economic crisis in Africa worsened. A striking similarity 
in the problems that they find to explain the food problems in Kenya is pertinent and proves that little has changed structurally in the country's food production and supply policies since the 1960s.

\section{IMPACT OF POLITICS ON FOOD PRODUCTION IN POST-INDEPENDENCE KENYA}

Although difficult to measure in the author's point of view, the impact of politics on food production in Kenya after independence can be summarized on two aspects: political institutions and allocation of state resources.

On political institutions, the Kenyan state has been since independence a one-party state under the heavy command of the presidency. Therefore, such an institutional arrangement does not offer freedom of participation through political parties. Political parties are essential to agglomerate the interests of citizens on a broad basis and to provide channels through which those interests can be voiced. This thesis finds that only institution of broad participation during Kenyatta's era was the Harambee policies of self-help and the policies of Kenyanization. The lack of institutions of participation makes difficult for peasant food producers to express their needs in the agenda of national economic development. In addition, the lack of such institutions does not offer check-and-balance to the political elites who misallocate state resources into private pockets, ethnic favoritism and corruption.

On the allocation of state resources, the current political culture in Kenya is prone to a waste of state resources into private pockets, flawed projects based on ethnic bias, and huge military expenditures to support the undemocratic regime. For example, Dirk BergSchlosser and Rainer Siegler (1990) suggest that after independence, tribal politics favored the Kikuyu elite to appropriate almost $40 \%$ of the land that the Kenyan government bought back from the settlers in Kenyatta's land policy. Had institutions of participation been in place. this decision may have considered selling the land to the needy people rather than to 
the elites. The remainder parcels of land were redistributed to small holders and families. However, as Kemp (1983) suggests the fragmentation of land into small lots created a problem of returns to scale. The output for each lot is small and does not offer a possibility to diversify food crop production for each small holder. As a result, the overall food production for small holders is low.

Arap Moi's regime has continued to favor his ethnic group the Kalenjin for control of state resources. Loyal ethnic group members have becn placed at key positions in the military, police, finance departments and civil service. Increased military expenditures during Moi's regime (see TABLE XXX in APPENDIX A) has taken away considerable amount of resources which otherwise could have been dedicated to boost food production. This table shows that military expenditures (weapons purchases) took an average 9.1 percent share of total government expenditures in the $1980 \mathrm{~s}$.

The Kenya government is not particular for huge military expenditures. Even democratic nations such as the United States and socialist/communist states such as the former Soviet Union and China have spent as much proportion of their budget on the military. However, for developed as well as centralized economies, military industry provides jobs and stimulates the economy while in the case of Kenya weapons purchases steal away scarce resources from needy (or ignored) sectors such as food production.

Furthermore, TABLE XXX does not show any government expenditure specifically dedicated to food production enhancement. Expenditure entries classified under agriculture are subsidies to cash crop farmers and cash crop economy rather than food production.

Food production has naturally been a private activity since the beginning of humanity. It is understandable that the Kenya government has left this activity to the private sector, therefore, has not shown much interest in it. However, functions of government are regulative, allocative, distributive, and to stimulate the economy. Since the food production affects the livelihood of citizen populations and political constituency of the 
state, it affects not only the welfare of Kenyans, but the economy and the politics of the nation. Food security at national scale is a known legitimate concern and should be one for any modern state whether in times of abundance or in times of shortages. Food security for citizens falls in the realm of allocative, distributive, developmentalist, and regulatory policies which are the main functions of the modern state.

On allocative policies, the government should provide appropriate resources to food production so that this sector can be sustained and capable of securing self-help in food at national scale. On redistributive policy arena, the government must make sure that the poor and those in marginal areas have enough food as basic need. The government can achieve this end by stimulating the private sector to make food distribution more homogeneous (providing subsidies and infrastructures). The government in Kenya and many African countries has provided subsidies and food security mostly to middle class populations in the cities. The governments have insisted on subsidizing imported foodstuffs in the cities as a favors to maintain their constituency base in the cities.

On developmentalist policies, it will be demonstrated in length in CHAPTER IV -based on economic development theories that, boosting the food production sector is a very important step in economic development of a nation.

On regulative policies, the government must make sure that the prices of food are affordable to the majority of the population, particularly the lower class in the city and people in marginal areas where food availability is limited. It has been shown in this chapter that the Kenya government has done a poor job in regulating food prices. This thesis contends that the failure to regulate food prices is a normal result of the lack of a government policy regarding the food production sector of the economy. The food production sector has not been formally included as a legitimate sector of the national economies of sub-Saharan countries. Rather, it has been left entirely to the private sector to deal with. However, in cases where economies are not developed and agriculture 
mechanization not existent, the private sector is incapable of keeping the food production sector afloat to match demand.

In the next chapter, the present research tries to justify the needs for economic and development policies that emphasize food production in LDCs of sub-Saharan Africa including Kenya. Arguments to support the case are drawn from Development Economics theory. Dependency theory, and the experience of agriculture-rich countries such as the United States of America. Also, key issues pertinent to the African food crisis (for which the new strategies presented in this thesis try to provide solutions) will be exposed and further developed in CHAPTER V. 


\section{CHAPTER IV}

\section{A CASE FOR DEVELOPMENT POLICIES THAT CAPITALIZE ON BOOSTING UP DOMESTIC FOOD PRODUCTION IN SUB-SAHARAN AFRICA}

The previous two chapters focused on an investigation of Kenya's political economy from colonial to contemporary time. The goal was to search for the causes of current food problems that may be rooted in the characteristics Kenya's colonial economy and economic policies. The findings reveal that Kenya, as many countries in the sub-Sahara region, inherited an export commodity (cash crop and raw material) economy characterized by a notorious neglect of the food production sector in national economic development policy. Particularly, it was put in evidence that more emphasis has been put on export cash crops solely at the expense of food crops. In the case of Kenya, this characteristic was already present in the policies of the colonial government moreover the 1954 Swynnerton Plan reforms.

The present chapter is a short investigation of the African food crisis in the 1990s starting from far signals in the 1970s. Some statistics have been already exposed in Chapter I. This chapter focuses more on the roots of the African food crisis. In this section the impact of colonial economic and agriculture policies on the current situation is put in evidence. Policy recommendations of Western advisers are questioned and potential beneficiaries of the statusquo hypothesized. The chapter continues with an assessment of the role of a sustained food production sector in national development from a classical Development Economics perspective. Next, a shift of emphasis from cash crops to food crops is discussed as a viable policy to mitigate the food crisis in sub-Saharan Africa. 


\title{
SUB-SAHARAN AFRICA'S FOOD CRISIS: 1970s-1990s
}

In the 1980s and 1990s sub-Saharan Africa has been crippled by many problems: poor economies controlled by the state and relying mostly on primary commodity exports, deteriorating terms of trade in the world market, dependency on developed economies, lack of technological capability and capital to develop the manufacturing sector, debt burden, rampant poverty, climatic severity and food crisis, epidemics, and political instability. Added to these problems is the sharp population increase (4\% per year on average), the first in the world (Berg and Whitaker 1986). ${ }^{1}$ The 1970 FAO report (Christensen et al. 1981) already showed that 67 million people, about one fourth of the continent's population lacked adequate food supply. In 1975, the proportion rose to $60 \%$ of the population. The consequence is the rise of the food import bill. The conclusion reached by the report is that (Christensen et al. 1981):

\begin{abstract}
"Sub-Saharan Africa is the only region in the world where per capita food production declined over the past two decades... In 1978, per capita food production in Angola, Benin, Ethiopia, Ghana, Nigeria, Senegal, Sierra Leone, Uganda, and Upper Volta was less than 90 per cent of the 1961-65 average... Declining per capita food production coupled with chronically inadequate calorie intake means there is little margin for human error or natural disaster. Drought, political turmoil, or errors in policy can produce major food crises which threaten many with starvation. Famines in the Sahel and East Africa over the past decade make this too obvious."
\end{abstract}

The report (see Appendix B: Figure 4, Figure 5, and Figure 6) shows not only an increasing population growth in Africa, the first of the world in the 1990's projection, but also shows that Africa's yield for staple crops is lagging far behind those of Latin America and Asia. Furthermore, the index of food production in Africa is less than the average

\footnotetext{
${ }^{1}$ See also Figure 3 and Figure 4 in Appendix B.
} 
compared to those of Latin America and Asia, and has been sharply declining since 1970. It is not surprising that already in 1978 , the volume of grain imports in the continent started to increase drastically because of the insufficiency of food production (see Figure 4). The same Figure 4 shows that the cost of imports of food by sub-Saharan Africa has skyrocketed, especially starting from 1972. Combining with the chronic imbalance of the terms of trade food imports increased Africa's debt burden in the 1970s, 1980s, and 1990s. Furthermore, the statistics of the UN (UN Statistical Yearbook 1985/1986) confirm the same trends: sharp decline in food production, increase in food imports, chronic imbalance of the terms of trade, high population growth rate.

Reasons for food shortages. It is important to try to assess the major reasons behind food shortages in Africa. Seven major reasons can help to explain the decline of food production in sub-Saharan Africa. The first reason is the low output productivity of traditional (compared to modern) methods and technology to meet the demands of a fast growing population. As Hanley's analysis indicated (Figure 4), the rate of growth of the African population is very high compared to other continents. UN projections show an annual population increase of $2.5 \%$ per year in the 1970 s (Christensen et al. 1981) to $4 \%$ per year in the 1980s (Rotberg 1983, ix).

TABLE XXV, TABLE XXVI, and TABLE XXVII clearly show that Africa has consistently lagged behind the other two areas in mechanization and the use of fertilizers (TABLE XXV). While these aspects have increased almost twofold for the other regions between 1978 and 1991, they increased only slightly for Africa. The lax of increase of the output and yield results in poor growth of productivity and aggregate food production, for example, the poor yield for cereals shown on the tables. Therefore, food shortages seem inevitable because agriculture mechanization and scientific methods are very limited. 
TABLE XXV

MODERN INPUT USE, AFRICA, ASIA, AND SOUTH AMERICA, 1977

\begin{tabular}{||l|l|l|l|l||}
\hline Area & $\begin{array}{l}\text { Irrigated land as } \\
\text { a percentage of } \\
\text { total arable land }\end{array}$ & $\begin{array}{l}\text { Tractors per } \\
10,000 \text { hectares }\end{array}$ & $\begin{array}{l}\text { Fertilizers used per } \\
\text { hectare }\end{array}$ & Cereals yield in Kg/HA \\
\hline Africa & $1.8 \%$ & 7 & $4.4 \mathrm{Kg}$ & 924 \\
\hline Asia & $28.0 \%$ & 45 & $45.4 \mathrm{Kg}$ & 1804 \\
\hline $\begin{array}{l}\text { South } \\
\text { America }\end{array}$ & $6.1 \%$ & 57 & $38.8 \mathrm{Kg}$ & 1653 \\
\hline
\end{tabular}

Source: FAO, Production Yearbook, and Fertilizer Yearbook, 1978

\section{TABLE XXVI}

MODERN INPUT USE, AFRICA, ASIA, AND SOUTH AMERICA, 1986

\begin{tabular}{||l|l|l|l|l||}
\hline Area & $\begin{array}{l}\text { Irrigated land as } \\
\text { a percentage of } \\
\text { total arable land }\end{array}$ & $\begin{array}{l}\text { Tractors per } \\
10,000 \text { hectares }\end{array}$ & $\begin{array}{l}\text { Fertilizers used per } \\
\text { hectare }\end{array}$ & Cereals yield in Kg/HA \\
\hline Africa & $6.83 \%$ & 18 & - & 1175 \\
\hline Asia & $33.66 \%$ & 202 & - & 2100 \\
\hline $\begin{array}{l}\text { South } \\
\text { America }\end{array}$ & $8.81 \%$ & 64 & - & 1978 \\
\hline
\end{tabular}

Source: FAO, Production Yearbook, and Fertilizer Yearbook, 1988

Another problem is posed by urbanization on the demand side. Although the level of urbanization in Africa is still small compared to other continents, its growth is too high to provide the means to feed, employ, and house the populations in the inadequate urban centers. Furthermore, the low income growth exacerbates the food problem, because the unemployed populations lack sufficient income to afford the expensive foodstuffs. Also in 
urban areas, as the report suggests, there is a prevalence on the consumption of imported food such as bread (wheat products), farina, rice, cheap meat and caned food.

\section{TABLE XXVII}

\section{MODERN INPUT USE, AFRICA, ASIA, AND SOUTH AMERICA, 1991}

\begin{tabular}{||l|l|l|l|l||}
\hline \hline Area & $\begin{array}{l}\text { Irrigated land as } \\
\text { a percentage of } \\
\text { total arable land }\end{array}$ & $\begin{array}{l}\text { Tractors per } \\
10,000 \text { hectares }\end{array}$ & $\begin{array}{l}\text { Fertilizers used per } \\
\text { hectare }\end{array}$ & Cereals yield in Kg/HA \\
\hline Africa & $6.98 \%$ & 19 & - & 1251 \\
\hline Asia & $36.42 \%$ & 203.7 & - & 2840 \\
\hline $\begin{array}{l}\text { South } \\
\text { America }\end{array}$ & $8.91 \%$ & 64.7 & - & 2152 \\
\hline
\end{tabular}

Source: FAO, Production Yearbook, and Fertilizer Yearbook, 1992

Part of the low productivity of sub-Saharan agriculture is due to the lack of improved and modern methods of farming which increase the yield as well. As Christensen et al. report suggests, agriculture in sub-Africa is mostly extensive on expanded areas, and most of the subsistence food production takes place in the rural areas. A comparison of the number of tractors and the percentage of use of fertilizers in food production (see TABLE XXV) shows very limited input resources for Africa compared to Asia and Latin America. In most cases, African food production agriculture has remained subsistence and traditional. Another aspect of the problem is the environment itself. Compared to temperate regions, soils in sub-Saharan Africa are very fragile to erosion that removes all the top soils. In addition, the African farmer lacks improved methods such as irrigation to reduce adverse effects of the weather conditions such as droughts. Therefore, as Hanley's analysis suggests the drought problem is one of the major causes of food shortages in the Horn of Africa (Somalia, Ethiopia) and recently in South East Africa (Mozambique). 
The policies and priorities of governments that neglect food production to the production of cash crops for exports (Raikes 1991; Shapouri et al. 1981; Maletnlema 1991) are equally responsible for low productivity of food. This pattern of economic policy, as argued in the next section of this chapter, is the legacy of colonial economies. The patterns of economies, inherited from colonization are responsible for the neglect of food production for local self-sufficiency. Civil wars in many African countries (Ethiopia, Sudan, Somalia, Mozambique) also cause hunger and malnutrition because large numbers of peasants are often displaced the areas where they used to produce food for their subsistence to a long journey of hunger that results in the death of many, especially the children and the elderly.

Other causes have been found linked to poor marketing and distribution of foodstuffs between regions in sub-Saharan countries.

Consequences of food shortages. The consequences of food shortages in Africa are many. First, malnutrition is the most-striking. The US Agricultural Economic Report (Christensen et al. 1981) suggests that in $1975,60 \%$ of the total African population was malnourished. The UN FAO statistics (UN Statistical Yearbook 1988) show that the amount of calories consumed by Africans is less than that of any other continents. Rotberg (Rotberg 1983) suggests the same idea at the introduction of his book:

\footnotetext{
"Millions of Africans today are severely malnourished, and many more perhaps 100 million or more, would eat better if they could. In Africa there is a widespread caloric deprivation, seasonal and perennial hunger, and-climatic perturbations aside-little likelihood that the feeding disabilities of African life will soon be alleviated."
}

Severe malnutrition results in deaths of children at the young age. The second major problem associated with food shortage is famine and the increase in the number of deaths 
from starvation. The region of the Horn of Africa, mainly Somalia and Ethiopia, and currently South east Africa has suffered a tremendous food shortage in the 1980s (UNHCR 1991) causing deaths of thousands.

Another consequence of food shortages is the increase in food imports. As the Figure 4 suggests, the quantity and price of imported food have increased over time. With terms of trade sharply deteriorating, the price of imported of food is going high compared to local income and buying power of the many. This situation exacerbates the already significant burden that these countries, mostly non-oil exporters, face with the import of petroleum. Although food aid has increased it cannot meet the needs of the growing population. What follows is a limitation put on domestic savings and domestic investment.

The buying power of the populations, especially in urban areas, is small because the bulk of their income is spent on food that is very expensive. They do not have enough money left for other priorities such as health care, and education of children. The burden falls on the governments to subsidize such sectors through social programs. For example, the government has to subsidize food prices (imported foods) in the urban areas to appease the middle class. Therefore, it can be understood that the prospect of developing any industrialization is far away because of the lack of domestic capital. The basic HarrodDomar growth formula $g=s / k$ proves that growth recorded in some of those countries is contradictory to the reality of their economies because their domestic savings are almost insignificant. ${ }^{2}$

\footnotetext{
2 In the Harrod-Domar equation, $h$ represents the rate of domestic capital and $s$ represents the rate of savings. This model shows growth without development of many African countries where some amount of savings may be recorded, yet net domestic capital accumulation is almost non-existent. A foreseeable consequence of this is a cycle of poverty manifested by the fact that all the money received or saved goes to pay for the expenses, and there is no development of internal capital. The lack of strong internal capital market or its non-existence creates the second type of economic dependency of sub-Saharan countries on developed economies, that is, capital dependency which adds to technological and trade dependency. Senegal, Amin accuses, was forced in the early days of French colonization in that country to specialize in groundnut economy that does not match the real needs of the people of Senegal. Rather, it provided ground nut to the French consumers.
} 
The neglect of food production for local consumption is not to be blamed on governments solely. In the next section, it is argued that the economies of the former colonies of Africa have been set up by colonial powers to be mostly producers of primary commodity products and cash crops for the metropolises. Therefore, the continued structure as cash crop and raw material producers encouraged by capitalist institutions (GATT, IMF, World Bank) has led to the neglect of food production.

\section{UNDERSTANDING THE ROOTS OF THE AFRICAN FOOD CRISIS}

The patterns of economies known to most sub-Saharan Africa today still bear characteristics of their colonial period. That is, they are mostly resource oriented economies which produce raw materials and agricultural commodity crops for developed economies. Going in this sense some authors of Dependency Theory such as Samir Amin (Amin 1973) ${ }^{3}$ have accused current economies of the region of fostering neo-colonialism rather than independence that they claim. Expanding on the issue of food production, studies of the colonial history of countries, for example, Kenya (Berman 1990), Nigeria, Cameroon, and Ghana (Amin 1973), suggest a chronic neglect of the food production sector in national development policies of these countries. More emphasis has been put on developing infrastructures, education, large scale bureaucracies, and to some extent an unstained import substitution industrialization. Therefore, it calls for a careful investigation of the colonial setting of economies in the region to find the deeply anchored policy failures that contribute to current neglect of food production. At first, colonial agriculture policies need to be investigated. Second, policy advice of Western experts to LDCs of the region needs to be questioned due to their insistence that these countries to produce more cash

\footnotetext{
${ }^{3}$ For example. Amin (1973) suggests that the economies of West Africa have been mostly plantation economies for exports of cash crops or resources of raw materials.
} 
crop for needed foreign exchange to supply national accounts and to pay their debt and to earn more. Third, it is interesting to investigate who would benefit from food dependency of African nations with the current statusquo.

\title{
Colonial Agriculture Policy: Cash Crops for Export versus Food Crops for Local
}

Consumption. The colonial agricultural system of most sub-Saharan African countries, such as Nigeria, Kenya, Cameroon, Zimbabwe, Kenya concentrated on producing cash crops for the consumption of metropolises (Amin 1973; Berman 1990; Davidson 1989). ${ }^{4}$ Therefore, the economic structure inherited by these economies from colonization has been mainly of producing cash crops, raw materials, and other primary commodities. Added to

\footnotetext{
${ }^{4}$ In settler colonies, such as Kenya, Rhodesia, South Africa or Algeria, natives were either forbidden to grow cash crops for themselves or they were often forced by a system of police or taxation to labour for white settler farms. They were forced to produce cash crops to the benefit of the settlers at the expense of food crops that sustained their own needs (Berman 1990). Even the Swynnerton land, agriculture and labour reforms which gave African farmers right to own cash crop farms accentuated the decline of food production to the benefit of cash crop production for exports. In non-settler colonies, for example, in West Africa (British and French), the situation of the African farmers was different. Right from the beginning of colonial rule they were allowed to grow cash crop on their own for export (cocoa, groundnuts, palm kernels, cotton, and coffee) (Davidson 1989) . However, the prices were fixed by foreign companies which, in order to maximize their profits, made the differential between metropolitan resale prices and purchase prices to the African peasants as big as possible. The profits often went back to the metropolis instead of developing colonized countries. The other two consequences as Davidson suggests were (1) indebtedness of successful African farmers because their revenues could not cover the cost of production, and (2) in the long term cash crop took over food crop security and food shortages started to rise (Davidson 1989, 18-19).
}

\begin{abstract}
"Another consequence was long-term. The more that farmers turned to export crops, the less food could they grow for local use. Because of this, local food shortages began to be felt as early as the 1930s. For the same reason, such food shortages would afterwards become much worse. Continuing on the same lines, even though independent, many African states today have to import expensive foreign food because their farmers do not grow enough food at home. Here was another way in which the colonial systems set a pattern of export that was bad for the majority of people. "
\end{abstract}

This observation of Davidson is very important for this thesis because it justifies the claim that the food crisis that many sub-Saharan African countries face today has a lot to do with the pattern of economies and particularly the cash crop economy. The latter stole away the emphasis by traditional peasant farmer on food crop production for their own subsistence to the benefit of cash crop production for export to serve the needs of the colonial metropolises. In addition, post independence African states have relied on import of foodstuffs from the former metropolises, often more expensive for the common citizen's ability to pay. The long term consequence accused by this thesis is food dependency on developed nations of the North which adds to technological and capital dependency. 
the economic weakness of these countries compared to countries of the northern hemisphere, little change has been achieved to transform these economies into exporters of manufactured goods even finished products derived from cash crops. Furthermore, the heavy concentration on cash crops has resulted in the neglect of food production for selfsufficiency (Raikes 1991; Shapouri et al. 1981; Maletnlema 1991).

Robert I. Rotberg (1983) in his introduction accuses the African countries of inheriting an urban based strategy of development that neglects the rural areas to the benefit of urban areas. He writes (Rotberg 1983):

\footnotetext{
"Never the less the nations of Africa, particularly the ones with which this book is primarily concerned - Zambia, Malawi, Kenya, Tanzania, and Uganda- have, since they achieved independence, systematically favored their urban over their rural sectors and, by design or neglect, undermined the productivity of what were their remarkable successful subsistence (as well as cash) growers of food."
}

Rotberg also accuses the lack of infrastructures to supply the rural areas with fertilizers, money, and incentives. Vail (Rotberg 1983) shows that in Malawi, for example, the white farmers dominated the agricultural sector with large scale cash crop plantation-agriculture at the expense of food production for Africans. They forced the indigenous people to work in those farms, and they did not encourage sufficient food production. Rather cotton growing, coffee, tobacco, and tea were favored over food production. Ian. R. G. Spencer (Rotberg 1983) goes further to show in the case of Kenya that colonial administration favored the needs of white farmers at the expense of pastoral production of the natives that they viewed and qualified as primitive. The consequence is that the self-sufficiency and the orientation towards food production have been replaced entirely by cash crop production.

According to the US Foreign Agricultural Economic Report, the colonial experience is heavily responsible for the current setup of African economies. The colonial economies insisted on dualistic structure with a modern sector and a traditional one. The latter 
produced raw materials and staple food for the metropolises. Internally, the rural areas were set to produce food for the urban areas. The major consequences were that food production became merely subsistence activity. The report indicates (Rotberg 1983):

\begin{abstract}
"While there were major regional differences, several common themes emerged. African food production became a primarily subsistence activity, even in areas where substantial trade in foodstuffs existed before colonialism. Second, male participation in the off-farm work force in cash crop cultivation frequently makes women more responsible for food production. Third, the lack of colonial interest in African food production meant little sustained research on food production, and hence, a relatively poor understanding of African production processes. Recommendations for change were frequently counterproductive. Research on export crops was more extensive, and generally more productive. In almost all, African countries of the region are producers of cash crops."
\end{abstract}

Kemp (1983) discusses the example of Kenya which has remained a primary producer of cash crops: coffee and tea mostly. Cash crops have played an important role in the economies of both Ivory Coast and Nigeria since 1960 (Amara and Founou-Tchuigoua 1990). These are cocoa, palm kernels, palm oil, cotton, groundnuts, rubber and sugar in both countries; coffee, bananas and pineapples in Ivory Coast only. These two examples show the heavy reliance of these countries on cash crops. ${ }^{5}$ Cameroon is another example of an essentially cash crop exporter: cocoa, coffee, tea. Most of these countries have conserved this pattern of production and almost no diversification of their exports.

Goran Hyden addressing the issue of Agriculture finds that the modes of production in sub-Saharan Africa have remained traditional; he writes (Berg and Whitaker 1986, 54):

${ }^{5}$ Bernard Founou-Tchuigoua (Amara and Founou-Tchuigoua 1990): Cash crop production in 1982 as percentage of total world production. The following are excerpts of leading position statistics:

- cocoa: Ivory Coast, 25\%; Nigeria, $8 \%$; Cameroon, $6.75 \%$.

- palm kernels: Nigeria leading with $15.71 \%$ of total world production.

- cotton: Nigeria, 27\%; Ivory Coast 27\%;

- groundnuts: Nigeria is the largest African producer;

- coffee. bananas, pineapples: Ivory Coast is the leading African producer. 


\begin{abstract}
"While African framers today are engaged in commodity production, usually for world markets, their systems and modes of production, usually remain pre-capitalist in nature, characterized by low productivity levels per unit of land. Unlike capitalist production units, activities are not differentiated according to a strategy of specialized production, nor is labor specialized; hence money wages are still a marginal phenomenon in Africa's rural economies."
\end{abstract}

He finds that compared with Asia African agriculture cultivation remains extensive in general rather than intensive. In Africa, more people tend to be involved in food production at the family level because of extensive land and lack of mechanization. In the US, on contrary, because of mechanization and high yield crops, only $5 \%$ of the population are involved in agriculture production. Another reason he finds is that the African rural farmer enjoys a high degree of autonomy. Therefore, he may be less sensible to government policies. Goran Hyden concludes (Berg and Whitaker 1986):

\footnotetext{
"To the independent peasant producer, the state is structurally superfluous and most public policy actions aimed at improving agriculture are viewed as having little or no value beyond any possible immediate gains to the producer himself."
}

Hyden suggests that African governments are inadequately placed to influence agricultural development than governments in Asia or Latin America.

The consequences as discussed in the earlier section are many. First, agriculture has remained at the subsistence level. Second, the productivity of agriculture has not been enough to meet the demands of a highly growing population. Third, poverty and malnutrition have increased because of the high cost of food compared to income. The import of foodstuffs subsequently has added to the worsened balance of payments to become a serious impediment of economic development. 
In response to the magnitude of economic crisis in sub-Saharan Africa (debt crisis, underdevelopment, lack of capital) comprehensive solutions of Structural Adjustment Programmes of the IMF, the World Bank, ${ }^{6}$ and Western advisers have insisted upon African economies producing more export goods (cash crops and raw materials). In their view more production of cash crop is the best way these countries can earn more revenues by specializing in what they produce best. Cash crop sales would earn foreign exchange and help them reduce their debt. It can be concluded based on this rationality that the prescriptions do not help with food production for basic needs of the populations. The countries embarked either in commodity exports or in expensive ISI at the neglect of the food production sector. This aspect will be the main point of the discussion in the next section.

Causes related to current economic/development policies of African countries after independence. Although generalization of the causes of the food crisis to the region of subSaharan Africa is not sound, some common characteristics or causes can be drawn for various countries that have been mentioned in some studies from which this thesis borrows (Shapouri et al. 1986; Raikes 1991; World Resources 1990-91). Raikes (1991) has raised key reasons for food problems in sub-Saharan Africa: (1) government neglect of the food production sector, (2) the bad marketing and distribution systems aggravated by government control and the lack of infrastructures (better roads and storage facilities), (3) the backwardness of technology which makes the food production agriculture too dependent on the weather and on human labor input alone, (4) the influence of aid policies of developed economies on the food production sector in the region, (5) the inequality of

\footnotetext{
${ }^{6}$ See Berg Report and Bruntland Commission Report.
} 
access by women to decision making and resources needed for agriculture, and finally (6) the political and economic conditions of the countries in the region.

Livernash (World Resources 90-91) has highlighted the food crisis in Africa by identifying Africa in the 1990s as the only region in the developing world with declining per capita food production since the 1970s (although the overall food production has increased) and the most reliant on imported foods from developed countries. Some reasons such as the following can help explain food shortages. First, population growth is very high and combines with slow economic growth. Second, serious environmental degradation and lack of arable land in certain areas are caused by demand for fuel wood, and livestock grazing. These practices, added to forest burning as a cultivation method, deprive the soil from vegetation cover. As a consequence, erosion of the top soil is worse and in many cases the soil looses its natural ingredients. Hence, land scarcity presents a serious challenge for the African farmers in the need to increase productivity in a uniquely inhospitable environment in many cases. ${ }^{7}$ Added to environmental hardship, rainfall in some areas is sporadic (in arid or semi-arid areas) or heavy (in tropical and equatorial areas). In any case the heavy rain contributes to serious soil erosion because of the lack of vegetation cover. This host of conditions shows that African peasant farmer's agriculture is greatly dependent on the weather and the environment. Traditionally, African farmers have practiced shift cultivation to adapt to the environment. Shift cultivation can sustain agriculture indefinitely even in arid areas. However, the fast population growth makes it almost impossible now to fully use this ancient technique.

The third reason according to Livernash, which explains the food shortages, is the policy environment in the region. Agricultural policies undertaken by governments have been mostly counterproductive. ${ }^{8}$ Such policies are the imposition of controls on the

One fifth of the continent is a desert and 10 per cent of the soil is too sandy for cultivation.

" World Resources 1990-91, 91) Most governments have, for example: 
marketing and distribution, inefficient state-owned food processing plants and plantations, the pricing policy of the government to favor consumers has left no incentives for peasants to sell through official channels, overvalued exchange rates, and neglect of rural infrastructures where the food is produced. In addition, unequal access of women to credits and resources (land titles and security tenure) needed for food production while they are responsible for $70 \%$ of the staple food produced domestically. In some parts of the region they are responsible for $60-90 \%$ of the food production labor force.

For Kenya, five major problems of food production agriculture were identified in this thesis (Berman 1990; Raikes 1991; Shapouri et al. 1986): (1) very high population growth, (2) the scarcity of arable land, (3) the technological backwardness and the lack of good road infrastructures, (4) the inefficient marketing and distribution system for foodstuffs aggravated by government control, and (5) the unequal access of women to capital and other input resources for agricultural production. These problems added to the chronic neglect of the food production that the country inherited from the colonial setting of its political economy which emphasized cash crop production.

Davidson (1989) has gone further than Raikes and Livermash to suggest structural causes in the post W.W.II world economy as the root of African food crisis. The structure of the world economy between the core and the periphery made that former colonies were caught up in producing cash crops for the former metropolises. This fact created dependency of the peasants on the cash crop economy from which they could not switch

-Imposed controls on the marketing of key crops, often banned private trade, and frequently set up state-owned food-processing enterprises that were often costly, inefficient, and slowed agricultural developement;

-Set producer prices so low, in order to keep consumer prices low to satisfy rapidly growing urban populations, that there was litle incentive for farmers to market through official channels (27);

-Allowed overvalued exchange rates, resulting in cheaper imported foods than local products, so that urban populations developed a taste for imported wheat and rice, neither of which is well suited to local growing conditions (28); and

- Neglected rural roads and rural infrastructure, in general, and the developement of rural and secondary towns. 
dramatically to go back to sustainable inward-oriented economies. What followed was a gradual decline of the food production sector.

Naturally many governments resorted to the easy solution of importing foodstuffs from outside Africa often at higher prices. ${ }^{9}$ What followed was a clash between rural areas and cities. While the rural areas expected to make more income from the sale of foodstuffs in the cities at higher prices, the cities on the other hand wanted cheap foodstuffs. The cities

${ }^{9}$ Davidson suggests that African nations came to independence with a host of problems: the deepening crisis caused by colonialism, rural poverty, rapid growth of urbanization with rural exodus, internal division with the increase of tribal competition for control of the state resources and power. On the economic grounds. the new governments had to assume responsibility of their own economies in a short term: working, earning, spending, managing the national wealth. These governments emerged with weak capability to plan their own economies which has been a serious problem which still goes on today.

The economic legacy of colonial period had two consequences on Africa. First, it continually drained Africa of wealth produced by African labour, land and natural resources. The situation continued in post colonial period with the adverse terms of trade for many African countries. The second consequence was that African countries joined a world trade and exchange organized by rich countries of the North, mostly former colonial powers, which control the wealth transfer from Africa. The wealth transfer from Africa operates in three ways according to Davidson. First, through exchange of raw materials against manufactured goods from the North. Second, through the fixing by the North of export-import prices which is a cause of adverse terms of trade for the South. Third, through debt-interest paid on loans, massive amounts of capital fly from Africa to the North. A visible consequence of debt-interest on loans has been the plunging of many African countries in a debt cycle because they cannot even afford to pay the interests in full.

To come back to the issue of food production which is the focus of this thesis, Davidson suggests that by 1960 s large rural populations in many African countries had become dependent on cash crop growing for their living. As an example, in Ghana farmers depended on cocoa for their livelihood and the government drew a large part of its revenues from cocoa exports. The issue is that with such a heavy reliance on cash crop economies. a cut off back to food production would have meant choking the economy and removing the source of income for the peasants already involved deeply in cash crop production. Davidson suggests that it was desirable for governments to cut slowly on cash crop production back to food crop production in order to reduce (1) the size of wealth transfer, and (2) in order to provide more labour and land to food crop production which were taken away for cash crop production.

These arguments are sound because, African countries have found themselves in a dependency trap on cash crop production where they have to produce more to keep receiving foreign exchange; yet the prices are set by countries of the North which provides them less revenues to match the input cost of production. With more production of cash crops in the world economy and less growing demand, their prices go down, therefore, the revenues from export as well. The countries are forced to borrow in order to pay the peasant producers and in order to fulfill their needs for buying manufactured products, services, and development needs. The situation is pretty similar to what happened to the western farmers with the increased mechanization of agriculture and the expansion of agribusiness industry (Raikes, 1991). On the output end the income elasticity of agriculture is low compared to manufacturing and the demand does not grow much. The farmer receives less revenues from sales of products. However, on the input end the farmer must buy fertilizers and machinery to increase the output in the hope to have more revenues. What happens is that the hoped increase in revenues for the farmer does not happen. Instead the farmer is caught up in debt in order to keep himself in business. A perfect consequence of this is the disenchantment from the agriculture
sector. 
naturally won because of their political power moreover because of the competition from imported cheap foodstuffs from abroad. It followed a general disincentive of peasants to produce more food in the rural areas. This situation in turn forced many governments to resort to more food imports to fill the gap. A long term consequence is food dependency on the North.

However, regardless of (1) the increase in food dependency and the heavy indebtedness of African countries, (2) the fast growing population in the area (the food needs of which cannot be sustained with continued food imports), and (3) the sharp decline in the world price of many cash crops, Western policy advisers have seemed to encourage more cash crop production and more import of foodstuffs from abroad because of the forced "open door" policies on African countries needy of loans from IMF, World Bank, and bilateral donors.

Western Policy Advisers: capital intensive and export-led agriculture versus food production for internal markets. Facing the food shortage problem in Africa and mostly the growing African debt the World Bank, the IMF and their advisers have imposed or suggested development strategies to restructure sub-Saharan economies. Most of these strategies have insisted on liberalizing domestic economies and promoting the export sector. However, the programs imposed on African countries have often led to detrimental conditions such as the sharp cuts in the social services that these governments used to perform (education and health). Other cuts have been suggested to remove subsidies on agriculture. This section examines the reaction and solutions of Western advisers to the food crisis in Africa. Berg suggests that the IMF and the World Bank programs encourage cash crop exports rather than food production; he writes (Berg and Whitaker 1986, 219): 


\begin{abstract}
"The controversy surrounding export versus food crop production is based on the contention of the World Bank and other international organizations that Africa should specialize in export crop in which it enjoys comparative advantage, and because its agricultural labor productivity is generally substantially higher in export than in food production. Also the specialization on food imports will even change the consumption component in these countries from tuber plants, millet and others to rice, wheat and corn."
\end{abstract}

Berg recognizes that the increase in food crop production will help in the long run to increase the amount of domestic savings, therefore, the needed foreign exchange to finance other essential imports (e.g., petroleum) that cannot be produced domestically. He suggests, therefore, a mixed strategy with equal emphasis on food production. This thesis sides with Berg in supporting that food production for local consumption will boost domestic savings, therefore, provide more capital for domestic investment and spare the earned foreign exchange from exports. It can be understood, based on the important contribution of the agribusiness industry to domestic GDP and local economies of developed countries such as the United States that, boosting food production will not only contribute to healthier domestic market, but it will help for development of the agribusiness industry with related industries. Also not negligible is that, with increase supply of food, the prices will fall to allow people to spend for other necessities including paying taxes to the state. However, the Structural Adjustment Programs (SAPs) in Africa have penalized for years the sector of the population on which food production rests strongly, peasants and women.

Christina Gladwin (1991) discusses the consequences or significance of Structural Adjustment for women farmers in Africa. According to her the adjustment packages include: devaluation of national currencies (accused of being overvalued), increases in artificially low food prices and interest rates, a closer alignment of domestic prices with 
world prices, an emphasis on tradable/exportable and the gradual withdrawal of restrictions on competition from abroad (trade liberalization), privatization policies (of "parastatals" or large-scale government monopolies), a decrease in government spending, wage and hiring freezes, reductions in employment in the public sector or the minimum wage, the removal of food and input subsidies, and across-the-board reductions in budget deficits as ways to invigorate stagnating economies.

Many of these prescriptions embody contradictions that are worthwhile addressing. Starting with increases in low food prices, the case study of Kenya (Kennedy 1987; Kennedy 1989; SRI CIS 1991) has proved that the price of food is very high, almost $50 \%$ of total income of the average household in the cities. Increasing food prices further makes food non-affordable when considered that poverty in Africa is becoming rampant (World Debt Tables 1989-90). On interest rates of loans, increasing the rates will do no good to the countries that are already locked in a debt cycle where they cannot even afford to pay interests alone (World Debt Tables 1989-90). ${ }^{10}$ The withdrawal of restrictions on competition from abroad is unidirectional. Developed countries, particularly America wants open door to their goods. However, manufactured products, semi-finite products, and competitive agricultural products from the South find erected barriers that do not allow them to enter the markets in the North. Full withdrawal of restrictions or protection of domestic industries will surely kill them. In the case of food imports, full removal of restrictions will do nothing but push African countries to become dependent on food from developed countries. Such dependency in the long run may choke their development for good.

11) The World Debt Tables (World Debt Tables 1989-90) show from private sources that the subSaharan Africa region came in 1989 with an outstanding debt of $\$ 140$ billion for total EDT and $\$ 40$ billion. a principal debt service of $\$ 8$ billion/year on average with interests of $\$ 4$ billion/year in average, a debt service ratio (INT/XGS)of 25\% in average per year between 1979 and 1989,and a EDT/GNP ratio of almost 120 in 1989. 
Privatization of state-owned companies and services and reduction in state-supplied employment are all sound strategies to increase efficiency and operation. However, state involvement in the economy in LDCs of Africa can be compared to the Keynesian prescriptions and applications in the United States during the Great Depression and after W.W.II, Kennedy's government research and Johnson's Great Society programs of the 1960s. The reason is that, the level of development there makes that wage earning is not high enough. Therefore, the state must provide services and some goods (such as electricity, water, health, education, and employment) that many cannot afford on their own, or which cannot otherwise be offered by private companies and individuals in a way to secure social justice. In addition privatization of parastatal services may be sound if the new owners are nationals. If ownership is foreign instead, there is a risk of a collision of the mission versus the market; market rationality may be used to justify the deprivation of needed basic goods and services to millions. Removal of food subsidies is even more a crooked prescription because in the United States the government heavily subsidizes farmers, and in EEC $80 \%$ of the budget is allocated to the CAP policy to protect and nurture their agricultural sector.

Gladwin's arguments against SAPs converge to the allegation that they have failed to stimulate growth or recovery in sub-Saharan Africa. Claims are that SAPs are more macroeconomic rather than microeconomic in the sense that they do not benefit the rural producers of food who are mostly the African women. They have failed to eliminate the urban bias and redistribution of income -- they have worsened agricultural production and incomes instead. The author accuses the SAPs to be gender-biased because the modern yield-increasing inputs are used only by men in the cash crop agriculture. The women who produce food do not see any of that. Gladwin accuses also the unequal access of women to land, credit and fertilizer, labor, and in many societies the right to grow cash crops at all. 
Given the SAPs' greater emphasis on cash crops for exports, men may appropriate more inputs than women who produce food, rendering the food production difficult. Therefore, the author foresees a food crisis for Africa. Another reason she finds to explain the food crisis that if food production remains in the non-monetarized sector or without incentives at all, price incentives designed to increase supply will have no significant effect. The solution then is that the SAPs must also encourage food production by women to serve the rural and urban areas.

Johnston O'Brien (Gladwin 1991) finds that higher food production is critical to increasing the backward and forward linkages to the manufacturing sector, i.e., achieving structural transformation in the future. Women are hit by cutbacks proposed by SAPs in health care and education. Women are not only producers but also consumers of products and education. Cuts in health and education make it hard for them to pay for school of the children and afford health care. In many households, the mothers are the ones who feed the family and provide school fees for children, especially in urban areas when the fathers do not have a job.

A Good example of boosting the food production sector is demonstrated in Guyer's case study of Nigeria (Gladwin 1991). The Nigerian policy has banned import of food and has forced the Yoruba women to produce more food because the prices were hiked. This has encouraged some women to start entrepreneur ship in food crops. Guyer suggests that "If price incentives are to be the solution to Africa's food crisis, and women farmers produce most of the food but cannot provide a supply response to increased price incentives, then more African food crises are in store for the 1990s." Therefore, she sees that structural adjustment does not guarantee structural transformation of these economies.

In sum, the SAPs, because of the removal of subsidies on education and health, increase poverty especially in rural areas. The increasing cost of health care and the removal of subsidy on education and health care is a serious burden on the income of those 
peasants. The money that they can have on food production or cash crop is spent for health and education of children. Therefore, there is not enough money saved for more improvement of production, for example, buying small agricultural machines such as chain saws and other tools to reduce human labor. Added to the debt, the SAPs encourage African countries to open themselves to unrestricted imports -- these include food, for example. The example of Nigeria has shown that cutting imports of food, although it has a painful effect in the short run can boost production of food domestically. The import of food helps MDC agricultural producers and makes the African farmer dependent on food imports from outside. New strategies to mitigate the food crisis should discourage food imports to the maximum. The best solution for Africa facing a possible wide scale food crisis seems to orient development strategies to boost food production for domestic consumption. Such strategies require not only a reconsideration of government food policies, but some level of technological improvement, and improvement in agricultural methods as well.

Food Dependency of African Countries: Whose Benefits in the Long Run? It can be suggested based on Raikes' assessment of international trade policies in the agriculture sector of US, EEC CAP, and other agriculture-rich countries of the OECD that, the African food crisis in the long run makes returns for many or help them fulfill their policies. The remark holds on two points.

First, agriculture-rich countries, particularly the US (with PL 480 programs) and the EEC (with CAP) solve their agriculture production surplus by dumping cheap foodstuffs and cereals in the world market destined for LDCs in Africa, Latin America, Asia, and former Communist countries. Therefore, a dependent sub-Saharan Africa on food would provide a market for agriculture-rich countries to satisfy their farmers by buying the surplus and selling it abroad. This issue is facilitated for the EEC by the Lome Convention 
agreements between the EEC member countries and former colonies in Africa and the Caribbean. For the US, the PL 480 has widely helped Egypt (the largest African recipient) cope with its food shortages starting with the Sadat administration in the early 1970s. A consequence of this flood of cheap foodstuffs in the world market breeds dependency of LDCs on food imports as a palliative for their food problems. A long term effect is the destruction of the food production capacity of these countries and their ability to feed themselves.

Possible beneficiaries of food dependency on agriculture-rich countries are not limited to farmers of the North. Political and business merchant elites in the South rip the exclusivity of benefits from imports of cheap foodstuffs that they resell to local populations often at higher prices. The other fact is that cheap foodstuffs help political leaders satisfy the demands of urban middle classes that otherwise would rebel against the government in the advent of food shortages or high food prices. The case for a sustained food production base as an important component of national economic development strongly holds for African countries to avert food dependency on the North as another vicious trap that would add to the structural, technological and financial dependency that they are already plunged in.

\section{SOLUTIONS PROPOSED TO ADDRESS THE FOOD CRISIS IN SUB-SAHARAN AFRICA}

Government strategies. Various strategies have been used to palliate to the food gap in sub-Saharan Africa. The strategy most widely adopted by many governments has been to increase commercial imports and food aid from developed economies to cover their domestic food deficiency. A major consequence of this "easy way" solution has been the indebtedness and the dependence of these economies on food aid and commercial food 
imports. With the growing economic decline in the region, the price of food is too high and food becomes non-affordable by many in the urban areas.

Another strategy has been to boost domestic production of cereals by adopting the cultivation of higher yield crops. These crops have boosted production output in many cases, for example, the hybrid maize in Kenya since the 1950s. However, hybrid species require a good amount of fertilizers to catch. Furthermore, they are more vulnerable to tropical insects and parasites. Hence, they require the extensive use of insecticides. Since fertilizers and insecticides are often imported from developed economies, the cultivation of certain hybrid species of crops may add to the debt burden of the countries to some extent.

A plausible solution, yet not sustainable for the indebted economies has been to boost production by increasing mechanization in the food production agriculture. The solution has implied the adoption by governments and private entrepreneurs of capital intensive agriculture: mechanization and large scale irrigation schemes to improve production output. The shortcomings of this attempt are: (1) the lack of capital of the impoverished and indebted countries which translates their inability to purchase new equipment, and (2) the non-sustainability of the methods to the physical environment. Also the reluctance of donors to put more money into inefficient projects is to be considered. Even in the case when they have been awarded credit for these expensive projects, the countries have been left seriously indebted. In addition, the serious imbalance of the terms of trade renders heavy machinery practically non-affordable by most private producers in the region.

A solution imbedded with government control has sought to increase the output by organizing peasant farmers' production into cooperative units of production. In both cases (cash crop production and food crop production) this effort has failed to produce expected results for two major reasons (Shapouri et al. 1986; Raikes 1991). First, it is widely recognized that cooperatives lack enough skilled people of their own to improve existing methods, or to create new ones to increase the yields and quality of the products. Second, 
cooperatives are very much drawn back by government control, regulations and centralization of the bureaucratic machinery. In some cases cooperatives have not been any object of improvement rather a drawback. Third, peasants resent cooperatives after many failures of these to satisfy their needs. It can be suggested that peasants consider "government-engineered" cooperatives as tools of exploitation by government officials. Such has been the case of failed cooperatives in Kenya in the late 1970's. ${ }^{11}$

Resentment of peasants to new food production methods of food production is to be considered as well based on the fact that, peasants who live off the land they own tend be conservative on their methods of producing food carried from generation to generation. ${ }^{12}$ Therefore, they may distrust agricultural experts sent by the government. Also, peasants tend to be independent and resist centralized government policies including taxes that they consider as a tool of government control and exploitation. It can be understood that new food production policies that do not involve peasants in their conception may face the same resistance faced in tax collection. One can suggest, therefore, that leaving peasants with the opportunity to organize their own production may seem an attractive solution to avoid resistance. CHAPTER V makes a strong recommendation that the government in subSaharan countries should change its role from centralized controller to a regulatory agent that will help people organize and funnel their energies towards achieving the ends that they seek. Many MDCs, while they accuse the leadership in sub-Saharan African countries for

\footnotetext{
${ }^{11}$ Shapouri et al. (Shapouri et al. 1986) suggest that many peasant maize cooperatives organized under state control failed in Kenya because they put a debt burden on the peasant producers. The peasants had to repay the loans that they had taken to purchase new agricultural equipment and chemicals. They had expected to repay with the returns of crop sales. However, the glut of food in the market in the late 1970s without judicious pricing policies from the state brought the prices very low and very less returns to the peasants. They had no money to pay back the loans. Therefore, not only they lost motivation in food production, but also developed resentment toward state-organized cooperatives.

12 See Gunnar Myrdal
} 
their flawed policies, have mostly predicated curbing population growth and improving technology as solutions for solving the food problem in the region.

Donor countries in the MDC bloc and multilateral organizations. Donor countries and organizations in the developed bloc have pointed the finger at two major causes of the food gap in sub-Sahara Africa that offset the slow food production growth to make the balance (World Resources 1990-91). The most important one is the fast population growth overall as well as urban population. They have, therefore, predicated limiting population growth as a long term strategy. After drawing from scenarios, ${ }^{13}$ the study shows that with current population growth of $3.5 \%$ there will be food shortages in the year 2020 unless population growth is reduced below 2.75\%. Therefore, the World Bank stresses that curbing population growth and maintaining a $4 \%$ growth in food production is the best strategy to avert the food shortages coming ahead. However, this solution does not seem to sell in many countries where birth control is not culturally accepted by the populations or there exists no government population control strategies in place.

The second cause of food shortages is accused on the technological backwardness of the countries in the region, which hinders their ability to increase food production output through mechanized agriculture and more efficient agricultural techniques. Added to this aspect is the total lack of research or limited agricultural research in many countries. Although agricultural research centers have yielded impressive results (example case of hybrid species of maize in Kenya, research on cassava in Nigeria, and other), they have

1. (World Resources 1990-91, 92). "If present trends continue (case 1)--population grows 3.5 per cent a year and food production 2 percent--the food gap (the amount required to provide 110 percent of the recommended intake of calories for the entire population (37)) would grow from 10 million metric tons in 1990 to 245 million metric tons 30 years later, in 2020. Even if population growth remains the same and food production grows 4 percent annually, the food gap would be 110 million metric tons by 2020 (case 2). Only if population growth declines to 2.75 percent and food production grows 4 percent annually (case 3 ) will the food gap stabilize and fall to 5 million metric tons by $2020 . "$ 
been slow to develop new methods and technology due to government neglect and poor management. To provide an immediate relief to the crisis, agriculture rich or donor countries in the developed world have fallen back on giving more food aid and allocating more loans as a short term solution to keep the countries afloat on their food crisis. Some countries have used food aid and food export policies to the Third World as means of doing away with their production surpluses or achieving protectionistic goals for their agricultural sector. Such are the cases of the United States with the PL 480 food aid programs, ${ }^{14}$ and the EEC agricultural protection policies through the CAP. ${ }^{15}$

The overall danger of these policies is that they create dependency of sub-Saharan African countries on food aid and food imports. Therefore, these countries are left with fewer incentives to develop their own food production sectors. With the high population growth (particularly in the cities) and the indebtedness of most of these countries, the solution of "being fed" from outside help is not sustainable in the long run. It would be beneficial in the long term even for the agriculture rich economies to give more incentives to

${ }^{14}$ The US has used PL 480 as a political leverage tool for its Cold War purposes and foreign policy objectives. Egypt has been for decades the biggest recipient of PL 480 and other food aid from the US in Africa. It can be suggested that the US has used this policy towards Egypt to obtain from this country the capacity to draw a coalition of Arab states less hostile to Israel and favorable to exploitation of oil from the Middle East (Gaddis 1982).

See also Dieudonne Mayi. (1993). Understanding the Motives and Implications of US Foreign Policy towards Egypt (1945-1981): Nasser and Sadat Administrations. Term paper for PS 507: "New World Order and US Foreign Policy"; Professor Mel Gurtov; Department of Political Science, Portland State University; March 1993.

In this paper the author held the argument that US apparent "predilection" towards Egypt shown during the Sadat Administration had nothing to do with good will, Carter's universalism, or his spiritual match with Sadat as some have suggested. The policy was specifically aimed at (1) coopting Egypt on the side of the US to mitigate the growing Arab nationalism favorable to the Soviet Union, which started with Nasser, (2) to use Egypt as a conduite to form a coalition of Arab states less hostile to Israel a protege of the US in the Middle East, (3) to bring the Egypt-Israeli conflict to an end, which had proven the capacity to distabilize the Middle East, a strategic economic area for the United States and the West because of its oil. The United States used the carrot of (1) food aid with the PL 480 programs, (2) loans, (3) grants, and (4) large military aid in order to draw Sadat into an unconditional surrender of Egypt as the US leading ally in the Arab world.

15 The EEC has used their Common Agricultural Policy to protect their agriculture from competitors such as the US, Australia and Canada. They have used the Lome Convention arrangements which allow them to dump their agricultural surpluses in LDCs, particularly former colonies in sub-Saharan Africa. 
sub-Saharan African countries to enhance their domestic food production. This suggestion holds considering the fact that even in the MDCs, diminishing returns of agriculture due to overuse of soils do not necessarily indicate that they will be able to feed the millions in most sub-Saharan African countries. In addition from the view point of classical Development Economics theory discussed in the next section, development of the food production sector has been justified by many authors as key to any sound economic development, particularly for LDCs.

Other strategy of donor countries and multilateral organizations has sought to increase and expand the scope of development assistance programs in agriculture. However, in many cases these programs have not fared well as indicated by the failure rate of 33-50 percent for Africa compared with 5 per cent for Asia. ${ }^{16}$ The current research finds that reasons behind this failure are not only linked with government embezzlement of project money, but also to the way projects are defined by officials (as well state officials than World Bank or donor requirements). Many projects are not suited to the cultural characteristics of the recipient populations and often do not match the environment. In addition, the projects as opposed to Asia are not granted to private entrepreneurship, which bounds them to inefficiency and low economic turnout eventually ending in failure. It has been recognized comparatively by the study (World Resources 1990-91) that projects awarded to NGOs or private individual entrepreneurs have often fared better.

Some prospects of solutions that many studies in developed economies have found for African countries to get out of the hole revolve around six macroeconomic reforms that call

\footnotetext{
${ }^{16}$ (World Resources 1990-91, 91). In 1985, the World Bank reviewed the short-term results of more than 1.000 of the projects it had funded. The failure rate in Africa was the worst of any region, and its agricultural failure rate was the worst of any sector. The failure rate for Asia's agriculture projects was 5 percent: by comparison, it was 33 percent in West Africa and 50 percent in East Africa. The worst sector within Africa's agriculture was livestock projects, which averaged a shocking-2 percent economic retum.
} 
for increased spending on food production agriculture ${ }^{17}$ increase the role of the private sector in agricultural economies, strengthen research and management, improve rural infrastructures, develop environmental protection plans, improve the role of women and give them more access to resources, land reform.

For solutions that add a feasible policy aspect to intellectual or non-sustainable recommendations. Many of the solutions investigated in this section have either produced palliative remedy to the food gap or they have failed to prescribe ways of implementing the recommendations. Therefore, some have remained merely an intellectual exercise. For example, some of these solutions stress empowering women. Yet they do not specifically draw a policy recommendation on how to do it. Others call for drawing men into food production to help women, yet they do not provide any hint of how to provide incentives to men directed at attracting the latter to food production. In CHAPTER $V$, this thesis provides not only conceptual solutions to increase food production, but it also answers the question on "how" these recommendations can be implemented practically.

${ }^{17}$ (World Resources 1990-91, 93). What must be done to prevent the suffering that may lie ahead for Africa? A recent study listed six key agricultural needs:

- Reform agricultural economies to increase the role of the private sector, provide for the free marketing of agricultural products, allow prices to reflect supply and demand, promote private investment in production, agricultural processing, and farm input supplies, and encourage easier access to credit in rural areas;

- Strengthen agricultural research management at the national level and boost intemational research efforts;

- Develop and maintain rural infrastructure;

- Develop environmental protection plans for each country to address soil erosion, deforestation, and watershed management issues;

- Strengthen programs to assist women as farmers and traders, and foster women's farm, credit, and marketing groups; and

- Provide legal and administrative mechanisms to facilitate land tenure (46). 


\section{SUSTAINED FOOD PRODUCTION BASE AND NATIONAL ECONOMIC DEVELOPMENT: THE IMPORTANCE OF DEVELOPING THE FOOD PRODUCTION SECTOR}

The issue of food production is part of the larger issue of agriculture development and cannot, therefore, be divorced from economic development for any given country. However, food production seems to draw particular attention because of its basic needs aspect for human life. The objective in this section is to give legitimacy to the need of developing or securing the food production sector on Development Economics grounds.

Development Economics theory and food production. Development Economics has the main goal of enabling a better understanding of Third World Economies to provide means and strategies for their improvement and by that way the lives of those people in those areas. There are four main leading theories of economic development regrouped in four approaches (Todaro 1983): (1) the linear stages of growth model, (2) theories and patterns of structural change model, (3) the international dependence revolution model, and (4) the neoclassical. free market counter-revolution model. Another model less popular in the literature is the New View of economic development of the 1970s which was heavily influenced by the push by Third World countries for a New International Economic Order (NIEO). The NIEO requests from developed economies of the North to facilitate more redistribution of wealth among developed and less developed countries by improving the terms of trade. eliminating protectionism of developed nations to competing products from the South, and transfer of wealth and technology to the South (Gilpin 1987). The New View of economic development also emphasizes on policies of basic needs for Third World countries.

The linear stages model that was predominant in the 1950s and 1960s sees the process of economic development as linear and progressive through stages. According to W.W. 
Rostow (1990) each developed country or economy has gone through five main stages of development to reach modernization: (1) the traditional society characterized by agriculture as the sole source of economic activity, (2) the pre-conditions for take-off into selfsustained growth, (3) take-off, (4) the drive to maturity, and (5) the age of the high mass consumption. The precondition for take-off is enough accumulation capital to support an industrial investment. The drive to maturity is characterized by high level of industrial activity. The age of high consumption is the postindustrial society.

The model of structural change focuses on the mechanism by which underdeveloped economies transform their economies from totally agricultural-based and rural subsistence economies to more urban, industrially diverse manufacturing and service economies.

The international-dependency model emphasizes the division of the world into core industrialized and periphery producer of raw materials (Theotonio Dos Santos of the International Dependence School. ${ }^{18}$ This view supports that underdevelopment is created by the relationship of exploitation by the core. Advocates of this model call not only for delinking of the periphery from the core, but also for a lessening of income inequalities within countries of the periphery.

The neo-classical counter revolution model of the 1980s calls for privatization of public corporations in developed economies and calls for dismantling of public ownership, planning, and regulation of economic activities in developing countries. Gunnar Myrdal, ${ }^{19}$

${ }^{18}$ ECLA school. See also Raúl Prebish (Rostow 1990) and Samir Amin (1976; 1985). Samir calls for a delinking from the core by adoption of inward looking development strategies which fully utilize the massive support of the people as a whole and serve their needs, rather than strategies that are outward oriented. Prehish suggested similar strategies earlier that Latin American countries can develop only if they acquire their own industrialization. Therefore, delinking from the core means for Prebish having import substitution industrialization. Either view does not suggest a complete cutoff. However, Samir's view is more appealing because it also calls for elimination of inequalities within each country. Prebish's view does not necessarily eliminate income inequalities because the ISI products as it has been criticized serve the needs of the internal bourgeoisie rather than the masses. Therefore, it is just a transport of the problem from core-periphery to periphery-periphery, i.e., between the elite bourgeoisie and the lower classes of proletariat and peasant class within developing nations.

\footnotetext{
${ }^{19}$ See (Rostow 1990).
} 
one of the prominent advocates of this view supports the point that what thwarts development of Third World countries is that governments have control of everything from politics to economics. They do not leave any chance for political democratization and free market opportunities that are capital to economic and political development according to the Modernization School.

These four models address each a different problem. However, the aspect of food production can be found in each of the models. Starting with the linear stages model, the pre-conditions for take-off suggested by Rostow's model, for example, require that the price of food be reduced by proper output production of the agricultural sector. With cheaper foodstuffs workers in the growing industry can save money to buy manufactured products and services that will continue the economic growth towards maturity. Without adequate food supply at cheap price, this model seems to indicate that the transition from all agricultural to manufacturing or service economy is problematic. This is to some extent true when a closed economy is considered. The argument does not hold strongly in the case of open economies in a free world market ${ }^{20}$ because it could be more advantageous to import cheap foods from abroad rather than developing a large scale food production at home. In addition, the example of the NICs has proved that industrialization is possible without necessarily passing the linear stages of the Rostow model. The NICs benefited heavy infusion of capital and foreign investment through MNCs and loans from the American government for Cold War containment (Gaddis 1982). However, it can be assumed that the price of food in those countries was not that high compared to incomes.

The structural change model shows the characteristic of many African countries that are still predominantly agricultural. It reveals as well the problems that they face to transform their economies from agriculture and resource-based into diversified economies

\footnotetext{
2) See W.H. Nicholls (Eicher and Witt 1964).
} 
(manufacturing and services). Also, subsistence agriculture can no longer feed the fast growing population in Africa, therefore, a food gap exists. This model sees the transfer of labor from the subsistence-overpopulated rural sector to the urbanized industrial sector. The problem with this recommendation is that industry has not picked up to absorb this excess of labour.

The international-dependence model calls for self-help in order to break the coreperiphery exploitative bond. Therefore, it would suggest enough output from agriculture to satisfy the basic needs of the populations in food. In the case of food needs for Africa it would suggest boosting food production to avoid the current food dependency of subSaharan African countries on developed economies. This model is very attractive for the thesis supported in the present research.

The neo-classical free market model calls for a change of government policies, from centralization to deregulation to allow more entrepreneurship. This would apply to government liberalization of controls over food production and distribution in LDCs, and encouraging private enterprise and entrepreneurship in the food production sector. Private entrepreneurship and competition are vital for improving output of food production and the quality of marketing and distribution systems. This aspect complements the internationaldependence view in a sense for policy making to succeed in African countries it must involve the people, not the elites only as is done in most cases.

The New View of economic development of the 1970s stresses reduction or elimination of poverty, inequality and unemployment, redistribution of growth between MDCs and LDCs on the one hand and within LDCs on the other. This implies in the case of basic needs, elimination of hunger and providing enough food base for everyone. It appears then that, for this objective to be fulfilled with the fast growing population in subSaharan Africa, it is important to boost food production. Sustainable development 
strategies must dominate new development policies, so that basic needs can be achieved by the many.

Taken from either angle, the linear stage models, the modernization approach, the neoclassical Marxist approach, or the New View, self-help in food production is stressed for any sustainable development of a given developing country. ${ }^{21}$ On the basis of this theoretical background the present research supports that food production for self-help is a necessity in the sub-Saharan economies. In addition the situation of the 1980 s with significant indebtedness, fast population growth, growing climatic hardships, and deterioration of economies with unemployment, it is imperative to concentrate on policies that promote basic needs and self-help. Therefore, increasing food production to meet the demands of the populations is a necessity to cut on food aid and indebtedness from commercial food imports.

The conclusion that comes up is that the agriculture sector in sub-Saharan African countries must produce enough food to meet the demands of the growing population and growing transition to pre-industrial or industrial phase. Supporters of comparative advantage in international trade and economics have widely demonstrated that a welldeveloped food production sector at the national level is no longer a strong prerequisite for industrial development. However, it still holds that food must be made cheap so that people can spend more money on industrial products and services. A way of making food cheap is to increase the output production of the food sector. In addition, borrowing from the NIEO on the basic needs policies and sustainable development in the Third World, it is justified to say that the moral duty of the state should include making sure that the populations have the basic needs, of which food security ranks first. Traditionally the primary moral duty of the state has been to provide security of its citizenry from external

\footnotetext{
"See Eicher. Witt, and Nicholls (Eicher and Witt 1964).
} 
threats. ${ }^{22}$ However, it is often taken in power politics theory from Western prospective that security from military threat or foreign invasion is the most important duty of the state (Russett and Starr 1989). In a capitalist system, the economic security tends to be less emphasized and its responsibility left to the 'invisible hand' of the free market conducted by the private sector. However, with the failure of the market to provide economic and basic needs security to the majority of people in African LDCs, it is justified to support the argument that governments must put more emphasis on providing security of basic needs for their populations. Therefore, the issue of food security must be seriously addressed especially in LDCs where significant development of capital and industry has not brought wealth overall to raise the standards of living of the populations. In addition in most LDCs that are still at the agricultural or pre-industrial stages, there is a need to make the transition to industrialization that require a good food supply basis that is sustainable and available.

Importance of agriculture in economic development. The importance of agriculture in economic development has been stressed by other theorists of Development Economics. Colin Clark (Rostow 1990) studied comparative study of agriculture of many developing regions as early as 1935 . He attacks the view often considered in MDCs that the declining proportion of the agriculture work force caused by the rise in per capita income justifies the positioning of agriculture as the least priority in modern economic development. His positive view implies that improvements in agriculture productivity are necessary conditions for industrial development. Clark's position with regard to this issue can be read in the following excerpt (Rostow 1990, 388):

"Both international comparisons and time series indicated that a rising proportion of the labor force in non-farm occupations was only possible if agricultural productivity not

\footnotetext{
22 G. L. Scott and C. Carr, Are States Moral Agents? Social Theory and Practice, Vol. 12, No. 1, Spring 1986
} 
only rose, but rose at an increasing pace.... The only exceptions were when a developing country could produce what we labeled "food substitutes"-mineral or forest products, or occasionally manufactures, which could be exported to world markets-and would bring in food imports which could partially substitute for the productivity of the country's own agriculture... You cannot employ an industrial population if you cannot feed them. In addition, economic development necessitates an increasing volume of imports (though many planners seem to have neglected this issue). These have to be paid for, and in most developing countries (apart from the exceptions mentioned above) the only possible exports are agricultural products."

Clark's position is sound because most MDCs in their economic advice to LDCs tend to bypass the food production sector which played an important role in their own transition from agriculture to industrial economies.

Another pioneer of Development Economics theory is Arthur Lewis (Rostow 1990) known for his two major concepts in economic development: the "anatomy of growth with unlimited supply of labor," and "the fundamental role of increased agricultural productivity in the process of industrialization." He too recognizes the critical position that agriculture plays in the process of industrialization.

Other views of economic development in the Development Economics literature insist on modernization ${ }^{23}$ or import substitution industrialization ${ }^{24}$ as prerequisites to economic development of LDCs.

${ }^{23}$ Gunnar Myrdal's view (Rostow 1990) insists on the process of modernization viewed from the political angle. i.e., the process of democratization. Modernization is viewed as the performance of a whole society and whole people, not merely its economy. He blames underdevelopment in LDCs as caused by government control of the economies and corruption from politics. Liberalization, democratization, and free market are a must for economic development. Myrdal's view, however, makes no mention of the agriculture development in the process of economic development.

${ }^{24}$ Raúl Prebish's view in the 1950s insisted on industrialization as key to achieve economic development taking the case of Latin America (Rostow 1990). His view is a critique of outward-oriented development which does not permit full development of those countries. Therefore, they must look inward and develop their own industrialization. He suggests development by implementation of import substitution industrialization. 
Carl Eicher and Lawrence Witt (1964) recognize an important role for development of food production base in economic development. Although they recognized the popularity of Rostow's linear stages model of economic development, they suggest that countries have particularities in their development patterns that do not call for a replication of development as Rostow's model seems to suggest. Most economic historians agree that no country in experience has fully developed without a rise in agriculture productivity preceding or accompanying industrial development. Today a more general view accepts that development need not necessarily be launched by either agriculture or industrial sector alone. Rather, each economy contains both components. The neo-Marxists and Amin particularly (Amin 1990) suggested that development is not linear. Rather it can be understood as a circular process centered on basic needs. Therefore, it can start and expand from any basic need to reach the other sectors.

Expanding on the place of agriculture in economic development, W. H. Nicholls (Eicher and Witt 1964) acknowledges that a large number of literature in history, theory, and economic development policy recognizes the dominant place of agriculture in the economic development of developing countries. Development requires that a vast number of people from the rural sector migrate to the cities. Therefore, substantial industrialization

\footnotetext{
"My diagnosis of the situation of the countries of Latin America was constructed on the basis of my criticism of the pattern of outward-oriented development, which I considered to be incapable of permitting the full development of those countries. My proposed development policy was oriented toward the establishment of a new pattern of development which would make it possible to overcome the limitations of the previous pattern. This new form of development would have industrialization as its main objective. In reality, my policy proposal sought to provide theoretical justification for the industrialization policy which was already being followed (especially by the large countries of Latin America), to encourage the others to follow it too, and to provide all of them with an orderly strategy for carrying this out."
}

Socialism is then necessary to ensure 'social use' of the surplus. Economic liberalism is also necessary insofar as individual decisions to produce and consume should be left to the market. Prebish makes no mention of food production as a significant development strategy. His view has been criticized because the ISIs try to duplicate lucrative goods from developed economies to satisfy the domestic elite bourgeoisie. Therefore, they do not address the real needs of the lower sectors of the society. In addition the ISIs have failed to find sustainable markets within the Latin American countries themselves. 
is needed to absorb this population for non-agricultural production. Investigating the relationship between agriculture development and industrial development Nicholls has found that agriculture progress is fundamentally a prerequisite for industrial development as is the case in a closed economy. In closed economies, the linear models suggest that the prerequisite of industrial development is the achievement of the rate of increase in agricultural productivity that exceeds the concurrent rate in the rate of demand for food. Therefore, the rising agricultural productivity supports and sustains industrial development in two important ways. First, it permits release of labour force from agriculture to industry while meeting the food needs. Second, it raises agricultural incomes, therefore, increasing the rural purchasing power needed to purchase industrial goods and rural savings that may then be mobilized to finance industrial development. It enables agriculture to produce foods at prices that are profitable for industry workers to buy and save to buy industrial products.

For open economies the rationale is not the same. Agriculture development is no longer a prerequisite for industrial development. With revenues from trade a nation can purchase food from outside at cheaper prices than produced inside. However, rising productivity in the food sector is desirable for two reasons. First, it may help save scarce foreign exchange needed for financing imports of industrial capital. Second, it contributes to the integration of the dualistic (plantation-peasant) agricultural economy, the existence of which often restricts the rate and spread of economic progress such as is the case in sub-Saharan Africa. This remark seems well suited to sub-Saharan African countries for many reasons. First, 60 to $80 \%$ of the population in many countries of the region live off the land in rural areas. Second, these countries do not have enough domestic savings. Therefore, savings on food bills can help meet this ends. Third, many countries in Africa have not yet developed significant industrial sector to absorb labor surplus from agriculture. Furthermore, if agriculture productivity is high the nation may enjoy food surpluses to 
export and savings of foodstuffs for adverse fluctuations in production years. In the first case African countries which have enough foodstuffs to export can do so to other countries of the region with less favorable climate. Such trade policies can help the problematic economic integration in Africa.

Industrialization contributes also to agricultural development. As an economy undergoes industrial-urban development, it accelerates the rate of agricultural progress in many important ways. First, industrialization increases the demand of wage-goods, of which food is initially the most important. Therefore, it opens markets for foodstuffs and specialization in cash crops, development of agriculture processing industries, and the integration of rural and urban economies. Second, industrialization provides the agricultural workers with a range of goods -- particularly equipment -- to improve productivity. This problem is a setback in the capacity of sub-Saharan African countries to increase the productivity of their agricultural sector. Industrial-urban development also creates an intellectual environment, which is more educated and has more skills for capital formation and technical innovation.

In sum, although it is hard to realize both at the same time, agriculture development and industrial development go hand in hand for many LDCs. Nicholls concludes that agriculture development is a key for underdeveloped economies to embark on the path to development (Eicher and Witt 1964, 16):

\footnotetext{
"Admittedly, there is probably no underdeveloped country which can at any stage afford to concentrate all of its investment on either agriculture or industrial development. However, in my opinion, not until it has succeeded in achieving and sustaining a reliable food surplus (or in at least reducing the food deficit to a magnitude which expanding nonfood exports might realistically be expected to cover in the near term) does a shift of emphasis to large-scale transfer of farm population into non-farm employment and to labor-saving devices in agriculture begin to make sense."
} 


\section{AGRICULTURE DEVELOPMENT: WESTERN COUNTRIES' EXPERIENCE VERSUS DEVELOPING COUNTRIES}

Western Agricultural experience. Often when they prescribe solutions and strategies to developing countries for their economic development, experts and decision makers in developed economies (the Group of Seven) advise LDCs "to follow their example." What this means is that Western development and modernization approaches (linear model theories) often predicate to LDCs that they must follow the same path that the today industrialized nations followed to move from agriculture and resource-based to manufacturing and service economies.

In the case of food production, for example, most industrial nations and other advanced economies have been characterized by a strong food production sector. This sector produces enough food to meet domestic demand and enough for commercial, relief, and aid exports to hunger stricken countries as well as those facing food gap in the Third World and the Communist bloc. It is interesting to remark that these countries which were mostly agricultural at the on-set of their development (the United States, Canada, and Australia in the New World), France, Great Britain, Germany, Japan, Australia (Eicher and Witt 1964) are the most exporters of grain in the world market in the 1990s. European nations of the EEC through the Common Agricultural Policy (CAP) provide cheap grain to the Third World and seriously compete in this market with Canada, the United States, Japan, and Australia. Also, because of a strong food production sector, the price of food in those countries especially the USA, Australia, Canada and the EEC is cheap compared to other individual living expenses. Compared to most LDCs in Africa where food expenses for the average urban family is sometimes more than 50 percent of the total household budget, the 
food budget in advanced industrial economies cited is a minimal fraction of the total household budget (see TABLE XXVIII). ${ }^{25}$

The low cost of food compared to manufactured products and services and its low income elasticity compared to these two categories is predicated in Rostow's linear stage theories (Todaro 1983; Rostow 1990) as a characteristic of a successful transition from agriculture economy to manufacturing and service economy. Therefore, this model suggests that increasing the food production sector output is a prerequisite for any developing country to sustain a growing industrial sector in the take-off stage of economic development. Two reasons are advanced to support this view. First, with increased food production, food becomes cheap so that the workers in industry and other sectors can save money to spend on purchasing manufactured products and services to run the economy.

The second reason is that, with a developed food production sector, especially enhanced with technology and high output/yield agricultural methods to match the demand of the faster growing population, there is a progressive migration of the labor force from farms to serve the manufacturing and service sectors of the economy.

For LDCs in sub-Saharan Africa eager to solve their food crisis and to develop at the same time, it would make more sense to engage in a policy lesson-drawing based on the example of the industrial countries that have successfully maintained a strong food production sector. A brief historical examination of the evolution of the agricultural sector in the developed economies cited above, particularly Europe and the United States, deems fruitful.

Raikes (1991) has well laid out the historical evolution of agriculture in Europe and the economic dynamics that have contributed to strengthening the food production sector in those economies to the proportions that are known today.

\footnotetext{
${ }^{25}$ Income elasticity of agriculture sector in the United States is lowest $(0.2$ per cent) compared to the other sectors of the economy (manufacturing and services) (Todaro, 1983). In addition, the American family spends on average 13 percent of household budget on food (see TABLE XXVIII).
} 


\section{TABLE XXVIII}

\section{AMERICAN HOUSEHOLD FOOD BUDGET AS A PERCENTAGE OF TOTAL INCOME (1986-88)}

\begin{tabular}{||l|r|r|r|r|r|r|r|r|r||}
\hline \hline Year & \multicolumn{3}{|c|}{1986} & \multicolumn{3}{|c|}{1987} & \multicolumn{3}{|c|}{1988} \\
\hline Category & $\mathrm{A}$ & $\mathrm{U}$ & $\mathrm{R}$ & $\mathrm{A}$ & $\mathrm{U}$ & $\mathrm{R}$ & $\mathrm{A}$ & $\mathrm{U}$ & $\mathrm{R}$ \\
\hline $\mathrm{IBT}(\$)$ & 25,383 & 26,053 & 21,336 & 26,966 & 27,795 & 21,963 & 27,941 & 28,929 & 21,894 \\
\hline IAT $(\%)$ & 91 & 90 & 91 & 92 & 92 & 93 & 92 & 92 & 93 \\
\hline HSize & 2.55 & 2.52 & 2.74 & 2.56 & 2.53 & 2.74 & 2.56 & 2.55 & 2.65 \\
\hline AvWkF $(\$)$ & 23.35 & 23.92 & 20.04 & 24.78 & 25.21 & 22.43 & 25.24 & 25.68 & 22.65 \\
\hline AvYrF $(\$)$ & $3,096.2$ & $3,134.4$ & $2,855.2$ & $3,298.7$ & 3316.6 & 3195.8 & 3359.9 & 3405.1 & 3121.1 \\
\hline Fexp/I & $13.4 \%$ & $13.36 \%$ & $14.70 \%$ & $12.29 \%$ & $12.97 \%$ & $15.64 \%$ & $13.07 \%$ & $12.79 \%$ & $15.32 \%$ \\
\hline
\end{tabular}

Source: Extracted from David M. Smallwood, Noel Blisard, James R. Blaylock. (1991). Food

Spending in

American households, 1980-88. Rockwillve, MD: U.S. Dept. of Agriculture, Economic

Research Service.

Legend: (1) Household category A (All), U(Urban), R(Rural);

(2) IBT (Average yearly income before taxes), IAT(Income after taxes);

(3) HSize (Household size), AvWkF (Average food expenditures per week and per person excluding alcoholic beverages), AvYrF(Average yearly expenditure on food calculated as $52^{*} \mathrm{AvWkF}$ ), Fexp/I (proportion of food budget as a percentage of earned income per year, the average of which in this table is $13.35 \%)$.

In a simplified analysis, he has carefully described and discussed the transformations that the agricultural sector in Europe and in the USA has undergone for centuries. The development of Western agriculture occurred in a three-stage model from the 'agricultural revolution' and revolutions of Europe over 200 years to the present. The change in the structure of Western agriculture has been bound by the development of capitalism and dominated by the development of industrial capitalism. The three stages are: farm-level integration, subordination to industrial capital, integration and modernization.

Starting with the first stage, 'agricultural revolution' in Europe happened with the break-up of feudalism and the shift to capitalist forms of land tenure. In terms of farm organization this was followed with three kinds of changes. First was the integration of 
crop and livestock production. Second was the introduction of crop rotation and foddercrops. Fodder was used to feed livestock which in turn produced manure to fertilize the soil, therefore, increase crop yield. Another aspect was the introduction of animal power in agriculture with horse traction as the first step in mechanization of agriculture, moreover the use of improved drainage. Release of feudal land to capitalist tenure caused exodus of impoverished peasants to cities while improved machinery and animal labour substituted farm labour. This marked the beginning of industrial revolution and urbanization by expansion of food surplus and the creation of a class of landless peasants who formed a working class in the cities. A major result of this transformation was the extinction of the peasantry and its replacement by farm units with wage-labour similar to capitalist firms. ${ }^{26}$

The second stage of agricultural development in Europe happened in the mid-nineteen century with increasing political and economic dominance of industrial capital. As the Rostow model suggests, the take-off stage for industrialization requires to keep food prices low as means of keeping wages low. Along with this transformation came the development of cereal production and transport routes to the 'new world.' This period was marked by increased impoverishment of peasants and the net cut of venture capital to family farming. With the movement of capital away from agriculture came the birth of agribusiness by the turn of the 20th century with the appearance of tractors manufactured by industry. Organic fertilizers were being replaced by chemical fertilizers. The development and massive production of livestock and dairy products were initiated. Also agricultural research institutions started to be created in the USA and Europe. All these

\footnotetext{
${ }^{26}$ Marx and other observers saw the organization of agriculture in farm units as similar to capitalist firms. Without a take-off of industry in the cities to aborb the landless, a societal breakdown and violent revolutions may have hindered the industrial revolution. This remark is very crucial for LDCs in Africa where 60 to $80^{\circ} \mathrm{c}$ of the population is rural. Without any industrialization to aborb the landless peasants, a dispossession of peasants of their land could be catastrophic.
} 
developments caused the swelling of towns and urban centers while rural areas became progressively depopulated.

The third stage in Western agricultural development was the integration and modernization of agriculture which occurred in two stages according to Raikes. First was the acceleration of non-agricultural inputs and scientific techniques to increase the output of production in the 19th century. These were encouraged by private capital as well as state capital with government concern about stabilization of dispossessed peasants. Equally important was the effects of income increase with the booming industrialization. ${ }^{27}$ A more important consequence in this stage was the full extension and development of the agribusiness and agri-state institutions (agricultural firms, banks, credit institutions), statesupported policies for agriculture, marketing boards, etc.

A consequence for the farmers came from the income elasticity of agriculture compared to industry or tertiary sector. As income levels rose and supply of food increased, only a small fraction of household income was spent on food, which caused a lowering of farmers' returns. Many small farmers were driven out of business or had to aggregate to form bigger producer companies because they could not afford to pay the cost of agricultural inputs. As the trend went on, the population of people involved in agriculture declined sharply to the $5 \%$ areas. It can be understood that farmers' production became bound by the agribusiness forces: on the input side by agricultural input companies and on the output side by consumer prices. However, strong state subsidies of agriculture in the

${ }^{27}$ The Engel's Law has two political and economic manifestations. The first is that as the incomes rise, the amount of household budget spent on food declines sharply which gives an incentive to buy more expensive foods (fresh vegetables and livestock products), especially for the middle class. The second consequence is that political stability is less threatened because of food prices. As income rises the urban population are less affected by food price increases, then unrest that originates from high food prices or food shortages -- a political threat for many governments in LDCs -- is averted. 
USA and in the EEC have helped the farmers dump their surpluses in the Third World. Governments have also allocated credits and subsidies to farmers in business.

Some issues are related to the structural change of agriculture: increased cost and purchase of agricultural inputs, replacement of human energy by fossil fuel, predominance of research and bioengineering, increase specialization in agriculture production. First the use of inputs (machinery, fuel, fertilizers, pesticides, seeds and others) has made modern agriculture in Western countries, particularly the United States, a capital intensive market activity. Mechanization and the use of fertilizers have dramatically increased production and yield per hectare. However, the consequences have already been noted by environmentalists as of the mid-1970s: poisoning of rivers and underground waters, destruction of soil texture by chemical fertilizers, and poisoning of consumers through contamination of foodstuffs from pesticides. The sharp reduction of the population of agricultural producers to a very small fraction of relatively large producers forces governments to provide subsidies to keep this sector in business to secure the food base in their economies. The USA and Europe are notorious for farm subsidies to protect their agricultural sectors from competition and from other adverse effects related to production. For example, the EEC spends almost $80 \%$ of its budget on costs related to protect its agricultural sector within the framework of CAP.

Another characteristic rising within highly advanced agricultural systems is the increased precision and system-dependence suggested by Raikes. Timing between production, supply, and deliveries must be met as well as standardized industrial procedures to keep the requirements of quality, quantity, and timing machine energy with fossil fuel.

Examination of the Western agriculture development experience may provide some elements from which new strategies can build in order to develop the food production sector in sub-Saharan African countries. The list includes (1) reorganization of farm 
production units, (2) bell-drawing on adverse effects of mechanization and the use of chemical fertilizers on the environment, (3) the advantages of increasing production to reduce the cost of food, (4) impact of Western model of agricultural development on the impoverishment and subsequent drastic shrinking of the peasantry, and (5) importance of research and private capital as well as state investment on the success of the agricultural sector. All those aspects will be taken into consideration in the search for new strategies to mitigate the African food crisis in the 1990s.

Developing countries' experience: case of sub-Saharan Africa. In the 1980s and 1990s, commonly agreed upon trends and problems in LDCs (African, Asian and Latin American countries) have been identified by researchers of the World Bank, WHO, and IMF, for example, to provide a broad characterization of LDCs as opposed to their MDC counterparts. Todaro has drawn general characteristics of LDCs (including sub-Saharan African countries) which reveal the many problems that these countries face in the struggle for development. First, living standards are very low compared to the North, which is manifested by rampant poverty in certain areas as a result of low or absence of incomes, inadequate housing, poor health systems, limited education, high infant mortality, and low life and work expectancy.

The second set of characteristics is found in the low levels of productivity with the lack of skilled labor, lack of management skills, lack of good physical health and the absence of well-established institutional framework to promote entrepreneurship and productivity. The third characteristic is the high rates of population growth (up to 3 to $4 \%$ growth per annum) and dependency burdens for large families. Particularly in the cities, it is common in large families that few work to support the others. Poverty is exacerbated with high and rising levels of unemployment or underemployment, and significant dependence on agricultural production and primary product exports (cash crops and raw materials). In 
most of these countries $65 \%$ of the population are rural and lives on the land. Agriculture contributes $20 \%$ of GNP versus $3 \%$ only for developed nations. All this host of factors leads to LDCs dependence on wealthy nations of the North, and their vulnerability in international relations because of the big political and economic power gap between the rich and poor nations.

One characteristic that can be added to this list is the growing inability of these countries to provide adequate food supply to their fast growing populations. Therefore, hunger and malnutrition crisis are growing in the African region. Poor health conditions combine with malnutrition to sharply reduce the level of individual work productivity. Because it's neglect leads to low calorie intake -- poor health -- hunger -- malnutrition -- low productivity -- and death by starvation in the worst case, food production is a major issue that should be taken seriously into consideration in the formulation of development policies of LDCs in sub-Saharan Africa.

\section{FOR POLICIES TO BOOST FOOD PRODUCTION IN SUB-SAHARAN AFRICA: INWARD LOOKING SOLUTIONS AND STRATEGIES}

The severe food shortage in Africa needs to be answered with feasible and inwardlooking solutions designed to boost food production in order to avoid a wide scale hunger in the continent by 20th century's end. The solutions that this research proposes can be grouped in three categories: (1) shift of emphasis of national economic policies from cash crop production alone to include food production, (2) curtailing imports of foodstuffs and cereals from agriculture-rich nations, and (3) technological improvement and research/development in high yield cultivation techniques and plant species. First, a change in agricultural policies by the governments should emphasize giving incentives for food production, integrating the peasant in the formulation and execution of policies, mixing the production of cash crops and food crops at the same time. The second solution is to reduce 
the imports of foodstuffs and grain from outside in order to force production of food domestically. Third, an improvement in technology and high yield farming techniques is necessary. The result of boosting the food production sector will help build a strong domestic market as Berg suggests, therefore, a possible increase in domestic savings and investment.

Bernard Founou-Tchuigoua (Amara and Founou-Tchuigoua 1990) has proposed similar strategies as those suggested by this thesis when he finds that agriculture in Africa (to avoid wide spread famine) must undergo three series of transformations: (1) its functions, (2) its techniques, and (3) the ways in which accumulation is controlled. ${ }^{28}$ For the transformation of its functions, he suggests that agriculture must undergo transformation from mainly cash crop producing to fulfilling the primary task of producing enough foodstuffs for local consumption. This solution does not, however, call for a suppression of cash crop production which is an important source of national revenues from exports. Rather, he calls for a mixed solution that keeps foreign exchange receipts and at the same time fills the stomachs at home without creating a financial burden on households or a serious limitation of their access to decent food supply. On techniques, Tchuigoua suggests that African agriculture must become technologically oriented -- not necessarily heavy mechanization or dependency on the use of input chemicals, but one that makes benefit of the existing labor force and the characteristics of the African natural environment and soils. On the last point he insists on putting the farmer in control.

28 Founou-Tchuigoua's strategies and those proposed in the present research are similar. However, he does not seem to provide an answer of how to make the transfer from cash crop dominated economies to those which attach importance to food production as well. My strategies provide a model of how policy makers can improve the value-added of food production activity, and make it beneficial and attractive to the food production sector of the population particularly the peasant farmer. Also, in the last point, he suggests to put the farmer in control, which he does not specify explicitly. My model of rural economic reorganization around the food production sector answers this question. Founou-Tchuigoua does not either seem to address the crucial problem of imported cheap foodstuffs from agriculture-rich countries which impedes on the seriousness of local policies to achieve self-help in food production from internal bases rather than just filling the food gap from food imports. 
The first solution to boost food production is to change government policies towards encouraging food production as Christina Gladwin's critique of the SAPs suggests. A change in policies of the governments is necessary. They must encourage small farmers and give women enough resources and incentives to produce food. This can be accomplished by supporting women equally with land titles, credits, farm equipment and other agricultural inputs. Men need to be given more incentives to get involved in the food production business to supplement women with the needed work force. SAPs on the other hand must encourage food production by giving or allowing governments to give subsidies to women for food production and being more flexible on the hidden "open door" policy often linked with loans. Another solution is to encourage small scale agricultural entrepreneurship as Berg suggests.

Clearly, as Founou-Tchuigoua suggests, there must be a shift from solely subsidy of cash crops towards production of food. This will help the objective of producing enough food for local consumption, yet keeping up with the production of cash crop to provide the needed foreign exchange revenues. By mobilizing rural farmers to food production as equally as to cash crops, they will be able to supply the cities with foodstuffs in a more sustainable way. A good production of food domestically will lower the price of food. Therefore, it will not only reduce the possibility of hunger, but also increase the buying power, and provide new jobs. Another issue related to policies is to integrate the African peasant more into government strategies of food production. As Goran Hyden (Todaro 1983) suggested the African peasant as opposed to the Latin American or Asian peasant is almost autonomous. Therefore, reforms of the government towards food production may not mean much for them since they are the peasants in general are reluctant to adopt new 
methods. ${ }^{29}$ Berg suggests to put the African farmer in control, i.e., to make him aware of the process and provide him with incentives for food production.

Some level of land reform is necessary, because certain areas of the countries, are very densely populated and others are not. However, in Africa ethnicity is often high. Also ethnic groups are usually concentrated on the same contiguous piece of land. Therefore, a land reform may bring political turmoil among the different ethnic groups. This thesis strongly suggests that land reform should respect ethnic boundaries in the rural areas within each country.

Todaro (1983) calls for development of rural economies and decentralization of national economies of LDCs. Urban economies in LDCs underdevelop and exploit rural areas (Amin 1976; Amin 1990). He suggests that in Africa, Latin America, and Asia, there is a sharp increase in population and poverty in the rural areas where almost $70 \%$ of the population are concentrated. Therefore, rural economic development must be given priority, and national economic decentralization is needed. Todaro concludes that "if development is to take place and become self-sustaining it will have to start in the rural areas in general and the agricultural sector in particular. For LDCs Todaro recommends an economic development strategy that is centered on developing agriculture and providing employment (Todaro 1983, 291):

\footnotetext{
"An agriculture- and employment-based strategy of economic development requires at a minimum three basic complementary elements: (1) accelerated output growth through technological, institutional, and price incentive changes designed to raise the productivity of small farmers; (2) rising domestic demand of agricultural output derived from an employment-oriented urban development strategy; and (3) diversified, nonagricultural
}

\footnotetext{
${ }^{29}$ Also Barbara Warton on "Risk, Uncertainty, and the subsistence farmer" in Struggle for Economic Development (Todaro 1983).
} 
labor-intensive rural development activities that directly and indirectly support and are supported by the farming community."

Yet the means to achieve decentralization need to be found. There is a need for policy makers to create business infrastructures in rural areas or to attract businesses to those areas. The present research demonstrates in CHAPTER $\mathrm{V}$ that reorganizing rural communities around food production and the agribusiness sector is one way of retaining people in the rural areas and achieving at the same time rural economic development and national economic decentralization. ${ }^{30}$

The second solution suggested by the present research is to restrict imports of cereals, meat, and other foodstuffs that can be otherwise produced locally. The benefit of this solution is to force people to produce more food. However, such a strategy is directly opposite to the prescriptions of the SAPs and the current GATT agreements of the Uruguay Round which impose full trade liberalization (with opening of the borders) on member states, particularly those of the Third World. The SAPs' prescriptions encourage the opening of LDC economies to investments and imports. The solution to continue importing everything from tractors to bread when the debt problem is getting out of hand is not sound. Curtailing imports will force domestic savings and most of all force people to find solutions from within. As long as people can buy rice, bread and other imported

${ }^{30}$ A parallel can be drawn between the neglected rural economies of Africa and the declining economies of rural counties in Oregon hit in the 1990s by the impact of habitat preservation of the spotted owl, the salmon, and other endangered species (Strathman et al. 1991; Haynes 1991; Haynes 1993). These economies have lost their sources of revenues from timber sales and fishing. Sound economic policies in Oregon are trying to attract businesses such as recycling and high tech to those areas. Other strategy aims at reducing timber exports and adding value to the scarce timber harvested by producing finished wood products in Oregon and selling them to other state and countries as suggested by Catherine M. Mater (Mater 1990). This will have the impact of creating new jobs in those hard hit areas. The parallel is the same for rural areas in Africa. For decades they have relied on cash crop activity as a source $f$ income or mining of raw materials. In the 1990s, the decline of world prices of commodity cash crops and the discovery of synthetic materials and minerals to replace natural minerals has caused the decline of revenues for the people living in rural areas. However, food production is an activity that these people are involved in for their own subsistence. More value can be added to this activity by appropriate economic policies which would render food production business more lucrative and attractive. 
cheap foodstuffs, they do not have incentives to produce food for themselves. Those who suffer the most from the situation are the poor, and the unemployed who cannot buy at all with current poverty levels. May be some quotas on food imports need to be imposed in order to satisfy MDC food exporters and trade policy makers.

Technological improvement, although it requires more capital and skills, must be geared towards producing tools that are used and adapted to the means, income and environment of the peasants. The present strategies strongly recommend that nonmotorized agricultural equipment such as the ones that were used in MDCs at the beginning of the century and up to the 1940s be adapted to help the African peasant farmer. Such tools will replace the rudimentary hoe, machete, and ax which are the basic tools of the African peasant farmer. These 'dinosaur' tools require a lot of physical effort from the worker than the new tools envisioned. In developing such a small scale technology, it will be possible to launch a basis for small scale industrialization around the needs of agriculture. Another aspect of technological improvement includes solving the problem of food preservation. The lack of food preservation expertise is directly responsible for part of the low output of agriculture. More research must be conducted to devise methods of storing and preserving local staples including tuber plants, fruits and varieties of vegetables. Canning techniques used at the household level in MDCs moreover in India can help because conventional preservation by electric refrigeration is very costly for the already poor populations. Other methods should include rural irrigation techniques such as water retention reservoirs (see Figure 24 in APPENDIX B) to provide water for crops and livestock during prolonged dry seasons. These reservoirs can also be used for fish and water products farming.

Robert H. Bates and Lofchie (1980) propose to encourage inter-African agricultural trade as it existed before colonization. This thesis sides with their solution that countries with surpluses should trade food with their neighbors who don't. However, this solution 
comes only in the long term, after food security has been re-established from domestic production. The reason is that most of the countries in sub-Saharan Africa are experiencing serious food problems or are about to face such an experience. Therefore, there is not enough supply even to meet domestic demand for many countries.

The strategies proposed in this research converge practically towards the same points as those of Todaro and Founou-Tchuigoua. However, the approach taken in this thesis differs a bit from theirs in a sense that it suggests "how to do it" rather than just raising the question about "what ought to be done." The solutions that discussed are feasible. However, some of these solutions may not be implemented in the short run. The climatic factor is still a key issue in Sahel regions where severe droughts make harvests uncertain. Other limitations are the high population growth that needs to be curbed in order for the food supply to catch up with the population increase. This may take time because it requires educating the populations to practice birth control. Acquiring a high output technology (mechanization) is not feasible for these countries which are for the most heavily indebted. Instead, the abundant labour force can be tapped to substitute high output technology. This approach offers solutions better suited solution for the realities of these countries. $^{31}$

In the next chapter, a conceptual model of strategies is presented to expand on the three solutions proposed for food production development in this chapter: (1) a shift from sole emphasis on cash crop to food crops as well, (2) curtailing food imports from agriculturerich economies outside the African region, (3) technological improvement and research development in the food production sector.

31 This remark draws from the trends that the costs of the means of productions are diametrically opposed between MDCs and LDCs. While capital is more available and cheaper in the North, labor is comparatively more expensive. In the MDCs of the South it is the opposite. 


\section{CHAPTER V}

\section{A CONCEPTUAL MODEL OF NEW STRATEGIES ${ }^{1}$ TO IMPROVE FOOD PRODUCTION IN SUB-SAHARAN AFRICA}

In CHAPTER II and CHAPTER III evidence was presented that current or prospective food crisis in Kenya can be linked to the colonial setting of its economy as a resource economy (agriculture and raw materials). This may seem obvious considering that developed economies started with agriculture and raw material production sectors before they diversified into manufacturing and services (Rostow 1990; Todaro 1983; Eicher and Witt 1964 ). However, for Kenya and many other countries in sub-Saharan Africa, the transition from resource economy to manufacturing or service economy doesn't seem to be near. In addition, a concern of this thesis is that a very important parameter of economic development -- food production -- has been given scant attention by governments. ${ }^{2}$ In the case of Kenya it was shown that (1) government neglect, (2) inefficient capital and technological investment, (3) policies notably the marketing, distribution and pricing of food crops are responsible for the food gap facing the country. Another parameter which equally contributes to the food crisis is the fast population growth.

1 Most of the conceptual strategies exposed in this thesis are drawn from my personal experience growing up in Cameroon, my native country in West Africa. For future work in food production development in sub-Saharan Africa, the strategies presented in this thesis will be backed up with statistical data analysis based on field surveys and second hand data.

- Discussion in CHAPTER IV justified the importance of developing the food production sector in economic development of a country, based on Development Economics theories and the experience of developed economies. 
The present chapter builds from problems of the food production sector in Kenya to develop a conceptual model of food production strategies that try to provide an answer to the food crisis in Kenya and sub-Saharan countries facing similar problems. It made more sense in this thesis to develop a conceptual model rather than to propose a full policy recommendation for two reasons. The first reason is that a policy recommendation on food production, supply, marketing and distribution, requires quantitative data analysis based on research and surveys on the field. The second reason is that strategies sought in this study are aimed at answering similar problems in other countries of sub-Saharan Africa. ${ }^{3}$ It should not be understood, however, that this study is trying to generalize strategies for the region, which is not realistic because economic, political, social, and environmental realities of these countries differ (Raikes 1991). Furthermore, the strategies narrow down to address specific problems within the food production sector.

The model proposed aims at being realistic in a sense that the conceptual solutions proposed are sought having in mind that they be feasible and sustainable in their implementation without much dependence on aid from developed economies. In the first part of the chapter, a brief discussion of important issues involving food production is conducted. Next, the strategies are exposed in detail and discussed. The chapter concludes with an assessment of the limitations of these strategies.

\section{ISSUES OF IMPORTANCE IN FOOD PRODUCTION}

There are a certain number of critical factors which affect the output and efficiency of a food production sector (Raikes 1991; Shapouri et al. 1986): production and supply (in quantity and quality), availability, distribution, marketing, and pricing policies. Strategies

\footnotetext{
"It was covered in the previous chapters that other countries in sub-Saharan Africa inherited cash crop and raw material economies from the colonial period and have remained so. These countries, most of which are facing a food crisis in the 1990s (see Hanley) suffer similar problems as Kenya, particularly government neglect of the food production sector in economic development policy.
} 
proposed in this thesis try to incorporate these considerations. However, pricing policy is not covered because it enters more in the realm of microeconomics and macroeconomics theory which are not the object of this thesis.

Production. Food production involves the methods and practices used to produce the foodstuffs. The inputs to the production process include human labour, capital resources (equipment and money), and land. Production is estimated in the quantity of foodstuff extracted per unit area of cultivated land in case of cereals and staple foods (FAO norms). For meat production, it is the number of heads killed for the market at any given time (day, month, or year). Estimation of the quantity produced is a real issue in LDCs economies where peasant production dominates local markets or where marketing and distribution are not well organized. Numbers presented to FAO by some countries in sub-Saharan Africa do not always reflect what is produced even in the case of large government plantations. Therefore, statistics produced by the FAO are sometimes misleading as Raikes has argued.

For human resource input, production implies the proportion or segment of the population (composition and numbers) involved in food production. The studies covered in this thesis have indicated that in many LDCs of sub-Saharan Africa, women are responsible for $80 \%$ of the food produced domestically and constitute $70 \%$ of the work force in food production. In general, however, the segment of the population involved in agriculture has remained high (70-90\%) which makes these economies mostly agricultural. Therefore, new food production strategies must take into account the impact on the vast population involved in agriculture. For example, mechanization of agriculture without a rise of the manufacturing sector to absorb excess of labour will deprive many of income revenues and a base for personal food. The studies observed as well that in most countries of the region, the bulk of local food staples are produced in the rural areas by peasants. 
Therefore, it makes sense to develop rural infrastructures and rural economies if the food production sector is to be improved.

The percentage of population involved in food production agriculture reflects also the level of economic development of a country. It has been suggested by some economic development studies (Todaro 1983; Kemp 1983; Rostow 1990; Eicher and Witt 1964) that as a country goes from agricultural to industrial stage, smaller and smaller portion of the population is involved in agricultural activity including food production. For example, in the US only $5 \%$ of the population produces enough food for the whole population and for exports. This reflects the level of technological advancement which has increased the output of agriculture without requiring a large proportion of workforce involved. In the case of many LDCs in sub-Saharan Africa, mechanization and industrialization have not picked up yet. Therefore, new strategies must take advantage of the abundant labour to offset the lack of mechanization.

Food supply. Food supply refers to the various kinds of food and quantities made available for the market to meet the demand of the populations. Supply also reflects the more important factor of nutritional quality of food to provide the necessary level of calorie intake required for the population. In some cases in Africa, the food is supplied but the nutritional quality is very low which leads to malnutrition as another sign of food crisis. This fact is shown in sub-Saharan Africa's low record (89\%) on daily calorie intake level required by WHO (see footnote 6 in CHAPTER I). For example, Kennedy Eileen's studies (Kennedy 1987; Kennedy 1989) have shown that, Kenyan families working in the sugarcane industry had enough money to purchase food and they did. However, the children were malnourished.

Food availability. This term has been well defined by Shapouri et al. and differs from food supply in the sense that availability reflects (1) buying power of an individual consumer or 
household to purchase the food supplied in the market, or (2) the food that is actually available in the market and ready to be purchased. In the first case availability can be understood as affordability of the food supplied. For a family, having the food in the store but non affordable to them is almost equivalent to the case of another family in an area where the food is not supplied at all. In the second sense, differently from food availability food supply reflects potential food in the market. However, it has happened in some cases that a lot of food was supplied to the market but because of bad infrastructures or bad distribution systems, its availability for certain areas was poor as in the case of marginal areas in Kenya. Therefore, the overall food supply quantities do not reflect the availability of food to the individual families. Extending on this explanation it can be implied that food availability reflects not only the marketing and distribution systems, but also the pricing policies.

Distribution. The distribution system consists actually of the network of producers, and retailers who bring foodstuff product from production sites (farm) to the retailer store or the local market. Distribution networks include also the various techniques used for storage, conservation, and transportation infrastructures. A good distribution system enhances supply in quantity and variety.

In the case of African countries, Kenya as an example, the studies covered in this thesis have suggested that the distribution system is very poor because of poor rural road infrastructures. Even worse, the number of storage facilities is very small. Therefore, excess surplus of cereal or foodstuffs could not be stored for times of poor harvest and shortages due to consumption bumps. A better distribution system could have helped marginal areas benefit from the surplus produced in more fertile areas. However, in the case of Kenya and in other African countries, the lack of road infrastructures leads to shortages and hunger in some areas while others have plenty of foodstuffs to waste. 
The issue of preservation of foodstuffs is crucial for storage and quality. Many native food staples in the region such as cassava, plantain, tuber plants, fruits, and other vegetables have not been preserved successfully at low cost due to humidity, high cost of energy, lack of technological skill and research to overcome unfavorable climatic conditions. It follows that the year long supply of certain foodstuffs is not possible or is very costly in electric bills. For example, it is not foreign to have lots of fruits during a season, and none for the rest of the year.

The distribution system also reflects the level of decentralization of economic activity. In many sub-Saharan African countries, the distribution of foodstuffs is not homogenous. In developed economies (such as the United States, Canada, EEC countries, Japan, and Australia) on contrary the distribution of foodstuffs is more homogeneous. In LDCs it tends to be from rural areas to cities for staple crops and reverse for certain kinds of meat, fish, and imported food products. The distribution system provides the critical input for the marketing system.

Marketing. The marketing system represents all the organizational apparatus that controls the levels of production in quantity and quality. It also overseas the distribution, storage and commercialization of foodstuffs. A good marketing system is the crucial nerve for self-help in food production. The marketing system also sets out production policies and policy objectives through boards and deals with import/export of foodstuffs. A marketing system should try to match supply to demand and control the prices.

Both Shapouri et al. and Raikes have accused the poor marketing system and marketing policies in Kenya as responsible for most of Kenya's inability to close its food gap from internal solutions. Particularly, it was seen that too much state control has discouraged producers or prospective investors in the food production sector. Free enterprise is hindered by state control which often involves inefficiency and corruption. As suggested 
in CHAPTER IV, state-organized cooperatives of peasant producers have miserably failed in some cases both in the food and cash crop sectors. Closely related to marketing and influencing it are the pricing policies.

Pricing. Pricing policies are another key issue in food production in the sense that low prices for foodstuffs discourage producers while high prices hinder food availability for the populations and cause inflation. In addition, a lousy pricing policy which disfavors producers encourages smuggling to the black market, especially in systems such as developing nations where regulation of market activities is almost impossible at the microlevel.

In the case of Kenya, for example, it was shown that the government has often reduced and held constant the prices of foodstuffs in order to increase the buying power of urban populations. However, government control has produced disincentives for producers (farmers particularly) to sell through state boards. The result is a growing black market network where producers smuggle products such as corn to sell them at higher prices in marginal areas and neighboring countries.

Also a good pricing policy must respond to the supply-demand mechanism, moreover to market fluctuations as suggested by Raikes. It has not been the case for Kenya as Shapouri et al. suggest where prices are overly constant and do not reflect the supply of foodstuffs in the market. In some cases prices have been manipulated by the government to appease the middle class populations in cities at the expense of rural producers.

\section{A CONCEPTUAL MODEL FOR IMPROVEMENT OF FOOD PRODUCTION IN SUB-SAHARA AFRICA}

The model tries to answer major problems of food production for which feasible and sustainable solutions can be found within African countries themselves. Such questions 
are (1) boosting production of local staples and foodstuffs ${ }^{4},(2)$ improving the marketing, distribution and storage of foodstuffs. Although both aspects involve government policy, question (1) needs more government action in the following ways: a shift in policy from cash crop towards food production, curbing food imports, providing incentives to increase production, a shift of the government's role from inefficient producer to regulator and catalyzer of private entrepeneurship, and development of rural economies, reorganization of rural communities, encouraging technological development with the exploration of entrepreneurial techniques (at the grassroots levels), and the role of vocational/engineering skills of graduates to produce new agricultural tools.

Also the solutions proposed are sought to accommodate the nature of the economies of most countries of the region where $80 \%$ of the population make a living on agriculture. Therefore, the new solutions depart from a sharp transformation from agriculture to industry (as was the case for developed economies in their growth stage) to recommend a mixed system of agribusiness and industry so that the rural economies and peasants can be accommodated. A sharp transformation from agriculture to industry would otherwise shrink the size of the food production sector while industry has not picked up significantly to swallow the agricultural labour.

Production: a shift of government policies from total emphasis on cash crops for exports to food crops. Although food production has been almost always a private enterprise (except in closed economies) it is however, the role of the government to frame food production policy at the national scale. Unfortunately, it seems that in most African nations

\footnotetext{
${ }^{4}$ Raikes observed in his study that in most African countries south of the Sahara (at the exception of hunger stricken countries like Somalia, Mozambique, and heavy importers of cereals such as Egypt) local local foodstuffs (in the exclusion of dairy products) are responsible for 50\% of the diet composition in the cities and almost $80 \%$ in the rural areas. Therefore, the model presented in this thesis emphasizes on increasing production of staple crops grown locally.
} 
referenced, food production policy is either non-existent or solely left to the private sector (peasants and small producers). It seems that governments are primarily preoccupied about securing food for urban populations in order to avert political crises that would originate from food shortages in the cities. Therefore, this thesis places government policy orientation as the backbone on which new strategies must find firm root. The issues addressed in this section are: putting food production as a priority in economic and development policy, curtailing food imports, empowering women, creating incentives to draw men into food production, technological improvement and the role of education, reorganizing rural economies around food production and agribusiness when favorable, regional trade of foodstuffs within sub-Saharan Africa.

\section{Putting food production as a priority in economic and development policy}

A key issue involves the role of the government as catalyzer of economic activity particularly to reorganize food production at the national level. This thesis does not intend to deny that in some countries food production policies have been undertaken by the government as indicated by the food production aspect of the Green Revolution. In Cameroon, for example, the Green Revolution policies of the government encouraged food production at scale. Yet, distribution and pricing were not well orchestrated always. The current widespread food crisis in sub-Saharan Africa leads to hypothesize that such policies were not mature or of lasting reach. It seems, based on the foreign advisers' emphasis on cash crops that, many governments of the region tend to consider food production as a given rather than the product of carefully designed policies. This thesis calls for including food production policies, marketing, and distribution in the national agendas of economic development. Governments must catalyze private entrepreneurship to produce food domestically for self-sufficiency rather than relying on food imports to cover food gaps. 
Encouraging food production requires the curtailing of commercial food imports from developed economies.

\section{Creating and strengthening institutions to help participation in decision making}

It was covered in the analysis in CHAPTER III that since independence power has resided strongly in the hands of the presidency in Kenya's a one party state (BergSchlosser and Siegler 1990). Besides the Kenyatta's Harambe (self-help) programs of rural development in schools, health care facilities, sanitation, and water supplies, politics have not allowed wide citizen participation outside the agenda dominated by the president and his political elite. Considering Lisk's (1985) argument that popular participation is needed in the planning for basic needs, this thesis calls for the Kenyan government to create more institutions that allow participation in the decision making process. Such institutions would include a multiparty system and a Congress of the People to aggregate the interests of the citizens and to provide channels where these interests can be voiced without political intimidation and too much elite control. In the food production sector, these institutions would allow rural farmers to voice their needs for subsidies, loans, and help with infrastructures needed for food production. Also institutions of participation will reduce the predominance of tribal politics which thwart resource allocation to benefit certain areas or members of particular ethnic groups to the detriment of the majority of Kenyans. A Congress of the People will also provide a powerful tool to prevent further waste of scarce national resources spent to purchase weapons to protect the undemocratic regime.

\section{Curtailing food imports}

Food imports are of two kinds as suggested in CHAPTER IV: food aid (relief emergencies and sharp food gaps), and commercial imports. At the exception of emergency food imports to cover shortages due to weather conditions, governments must sharply reduce food imports to force the populations to find solutions from inside. 
Importing greater quantities of foods from outside, as is increasingly the case for many countries, offsets the claims of Western policy advisers that is cheaper to import cheap grain than to produce it locally. Two reasons can help support this view. First, increased food imports in the long run create irreversible food dependency of these countries on developed economies. The danger is that developed economies will not be able to sustain such production with current population growth in LDCs and diminishing returns of agricultural mechanization. Hence, the concern on world population growth based on the scarcity of food is greater in the 1990's. Second, the buying power of the consumer in sub-Saharan African countries has been reduced so much that they can no longer afford even imported cheap cereals and other foodstuffs because of currency devaluation in the market. For example, in Cameroon and Gabon (Central Africa), the price of a kilogram of rice in the 1980s was roughly $300 \mathrm{CFA}(\$ 1.00)$. With 100 percent devaluation of the CFA currency in 1994 (in exchange value), the same kilogram of rice would now cost 600FCA which represents on average $0.2 \%$ of the average annual income in the case of Cameroon. ${ }^{5}$ Therefore, even imported cheap food has become prohibitive for populations. This conclusion may seem exaggerate because it does not consider government subsidies moreover that the bulk of the population with yearly income around the GNP value leave in rural areas where they cultivate their own land. However, it should be recognized that even in the cities, the decline of economic conditions and the layoffs combined with currency devaluation have seriously reduced the buying power of the average citizen.

Import of meat is even more expensive in quantity and quality because of preservation costs associated. Therefore, meat production must be increased and production of dairy products be accelerated domestically to meet the demand. Curtailing imports of foodstuffs

\footnotetext{
5 The GNP in Cameroon was $\$ 966$ in 1987 (see TABLE III) and is widely recognized to have dropped as a general tendency in sub-Saharan Africa (at the exception of some countries such as Ghana, Mali, and Nigerial. Therefore, a kilogram of rice worth $\$ 2.00$ alone represents $0.2 \%$ of the annual income of the average sitizen at the 1987 GNP level! This shows that even imported cheap foodstuffs are not affordable without heavy government subsidy.
} 
must be carried to protect domestic food production. However, this strategy will meet resistance from GATT trade policies which force "open door" on LDCs.

The tradeoffs of curtailing food imports do not seem encouraging in the short term, but this thesis supports that in the long run benefits will offset short term hardships associated with this policy. The shift of emphasis from cash crop to food crop production may cause a decline in the production of cash crops, which will affect the foreign exchange revenues of these countries. In any case there is not much to lose anymore since the prices of these commodities (at the exception of coffee and tea) have dropped dramatically in the international market since the late 1970s. In addition, restriction on imports of foodstuffs from EEC, US, Japan, Australia, Taiwan and China will face resistance because of structural settings such as GATT, IMF conditionalities for loans, and Lome Convention arrangements. This thesis recommends that the "bitter pill" be taken so that in the long run African countries can be self-sufficient in food production and avert food dependency on developed economies at a wide scale.

Curtailing imports of cheap foodstuffs must be carefully orchestrated with increasing domestic production to achieve significant and long lasting results. A prerequisite seems to reorganize production, which involves organizing inputs for best efficiency. In this case it calls for empowering women as the major segment of the food production workforce, and drawing in men as supplementary component.

\section{Empowering women and encouraging entrepreneurship in food production}

The studies covered in this thesis (Raikes 1991; Shapouri et al. 1986; FAO 1986/87) have suggested that women are almost entirely responsible for food in the households. They were found responsible for almost $80 \%$ of the local staples produced domestically and made up more than $70 \%$ of the workforce in food production. 
Since women have always sustained food production in Africa, the model calls for giving more means to women so that they can lead food production policy and its implementation. Clearly, governments can improve on food production by giving more leadership responsibilities to women in this sector. Along with leadership women need access to loans and other resources needed for food production. To make food production more market oriented and competitive, a careful blend of incentives and productivity enhancement strategies need to be applied. What this means is that incentives must be given to entrepreneurship of small agribusiness firms and industries in the food production sector.

Empowering women can be achieved with development of the agribusiness industry as will be expanded later in this chapter. This industry will create service jobs for unemployed women and housewives.

\section{Incentives for men to join food production}

Production of foodstuffs by women alone cannot be sustained to match a growing population because they have other energy-consuming task of bearing and raising children, and household work. To improve on food production quantities, it seems justified that men join women in this activity. Raikes has suggested that most of the staple food is produced in the rural areas by women while men concentrate almost entirely on cash crops. In tropical areas particularly, men provided women with physical labor to clear the land for cultivation. But as men became increasingly drawn in the lucrative cash crop production, women in most cases were left alone to produce food.

What is needed is to devise incentives to draw men into food production. This implies shifting emphasis away from cash crop production by giving value to food production. If the food production activity is found "rewarding" enough it can be hoped that men will join in. Objective conditions in the 1990s with the decline of economic conditions, unemployment in the cities, and sharp decline of the price of cocoa, for example, have 
drawn some men in Cameroon to engage in the production of foodstuffs (such as plantain) which they can sell for income revenues. From one case, this example proves that unfavorable conditions gave men incentives to revert partially from cash crop to produce foodstuffs for money. Drawing from this example, this thesis concludes that policies that would provide incentives for men to enter a lucrative food production activity would be beneficial to help women. Further in this chapter a point is made that development of a lucrative food production and agribusiness industry can draw men into food production when coupled with enough incentives and the curtailing of the imports of cheap foodstuffs.

However, it should be carefully stated that the incentives should be measured so that they will not withdraw men completely from cash crop production. What is targeted is the vast population of unemployed in the cities and those in rural areas who are suffering from the decline of cash crop prices. Therefore, a balance between cash crop production and food crop production priorities must be created.

\section{Technological improvement and the role of education}

It was argued in what preceded that reorganizing the labour input of food production sector can help increase the output, particularly that the labour is abundant and cheap. However, technology as another input can yield even a better result ${ }^{6}$ in a sense that technological improvement reduce human labor input and can help make agriculture be less dependent on weather conditions. Physical human labour input can be lessened in agriculture with the introduction of mechanization to increase the output per hectare of production. However, capital intensive mechanization is very expensive and depletes the

\footnotetext{
${ }^{6}$ In addition increasing one input of the production function of food production can yield diminishing returns. The production function of food production as any production activity can be generalized as $\mathrm{O}=$ $f(I, Z)$ where $I$ represents the inputs and $Z$ are other factors such as infrastructures and other market characteristics. The common inputs are labor $(\mathrm{L})$, capital $(\mathrm{K})$ and land $(\mathrm{L})$. Increasing one input can increase overall production. However, too much increase in one input alone can yield diminishing returns in the long run. In the case of human labor input, increasing the size of the labor force may cause management problems which will offset the benefits.
} 
soil in the long run. Another aspect of improvement in agriculture technology involves research to determine higher yield species and to devise irrigation schemes.

In this model two categories of solutions are proposed to help reduce physical labour: the use of animal power and the design of light non-motorized tools. In areas such as Sahelian regions where the Tse Tse fly is less present, animal power can be used. Even in humid equatorial areas this thesis suggests that animal power be equally used in rural areas. Peasants should, therefore, be encouraged to take advantage of animal power for traction (to lessen requirements on human energy) and manure for fertilizer. Light tools such as plows can be pulled by horses or cows to save human labor in tilling the earth. Horses and donkeys can be used to transport produce to market centers.

The task of producing new tools rests on technical education and that is why education enters into play to provide peasant producers with new mechanical tools which are improved compared to the traditional hoe, ax, or machete. The criteria for these tools is that they must be made affordable to the average peasant or small scale producer. Therefore, their design must be such that they do not require energy bills nor a considerable initial capital investment. Usually, the motorized or non-motorized tools (chain saws, light tractors, motorized pumps, and other tools used in agriculture) are non-affordable to peasants because of the low exchange ratios of their currencies compared to those of manufacturers in MDCs and NICs. Therefore, it can be understood why poor peasants are confined to using traditional tools such as the machete, the ax, and the hoe. The new strategies call for educational policy that encourages technical students to design and manufacture new tools. Outmoded tools that were used in the Western agriculture at the beginning of the century and which provided the basis for mechanization of agriculture in the West, can be copied with appropriate copyright agreements. The patents of such tools are cheap and the designs are available in libraries all over the developed world. 
The implementation of such a policy orientation in technical education will open the door to small scale entrepreneurship in agriculture tool technology. What will be needed is to help young entrepreneurs with necessary loans to help sustain small scale manufacturing of agriculture tools. A technology of small scale to help the agricultural sector obeys the requirements of the linear stage model prescribed by Rostow, i.e., it will help mechanize agriculture progressively and help increase production to provide a basis for the industrial sector to takeoff. Also, for the case of the US many researchers and policy surveys have demonstrated that productivity of agriculture was very high before W.W.II based on limited mechanization and the use of natural fertilizers (Raikes 1991; Eicher and Witt 1964). Modern techniques although they yield a bigger production capacity are capital intensive, destroy the soil, and pollute ground waters. In the case of African countries they are even not affordable at all. This observation calls for a policy in the agricultural sector which puts requirements and demands on young engineering graduates to find technical solutions, domestically-originated and feasible to help food production.

Similar efforts must be undertaken in food preservation and conservation with local methods rather than always relying on capital intensive technology and methods. This strategy discourages capital intensive technology and methods used by many governments who either own large plantations (Cameroon, Ivory Coast) or embark in projects of scale (the Bura irrigation project in Kenya.)

Another crucial problem facing food production agriculture in sub-Saharan Africa is its vulnerability to weather conditions as a sign of very limited irrigation (see CHAPTER III and CHAPTER IV). In many areas of marginal land such as in Kenya and in the Sahel countries, heavy but short rain falls usually occur during the small rainy season ( 2 to 3 months). This water can be retained in natural reservoirs (see Figure 24 in Appendix B) in each village to serve in time of dry season for irrigation of crops and livestock water supply. This reservoir can help also for fish farming and other animals such as alligators 
and crocodiles to supply protein. One problem with these reservoirs would come from evaporation due to sunshine three quarters of the year. However, it could be a little relief compared to nothing at all.

\section{Reorganizing rural economies around food production and agribusiness}

Earlier in this section, the thesis called for government incentives to draw men into food production, particularly in tropical/equatorial areas and in the cases where they are only busy with cash crop production. Such incentives may come from developing an agribusiness industry of scale. This sector will be responsible for producing and marketing various foodstuffs to substitute imports. Food processing plants will employ people in the cities and in rural areas for production and services. In addition, when proper incentives are opened in rural areas with the reorganization of rural communities and development of rural economic infrastructure as will be covered later in this chapter, people who are unemployed and in misery in the cities may find more attractive to return back to the land.

The phenomenon of reverse migration from crowded cities to rural areas has been observed at a small scale in some African countries (Cameroon, for example) where people who have lost their jobs in the cities and have objectively no way to support their families, or are retired. yet have a piece of land in the rural areas go back to live there. Revenues that they get from food production and sales in the cities allow them to continue supporting their school-age children living with relatives in the big cities. A dilemma comes, however, from the possibility that a massive return to rural areas could cause land disputes and require a full scale land reform.

This thesis suggests that land reform (if required) be done in respect of ethnic setting in the rural areas to avoid political problems and disputes between ethnic groups. In many African countries, land occupation has traditionally corresponded with ethnic boundaries which still exist today as in the case of Kenya, Cameroon, Nigeria and other. In the rural 
areas, land reform can be done within people of the same ethnicity in order to avoid ethnic crises. This proposition seems contradictory to advocates of full land reform. However, this thesis supports that "bounded" land reform as opposed to full scale one is a better solution because it would face less resistance from peasants, particularly those it will dispossess. Land reform has been easier in countries without high ethnic diversity such as Europe, Japan or communist countries under repressive regimes. It is not the same for Africa, particularly in sub-Saharan Africa where ethnicity is high. It would be a big mistake to carry out a full scale land reform without creating a serious discontent from the different ethnic groups that are majority in various areas touched by the policy.

\section{Regional trade of foodstuffs within sub-Saharan Africa}

One question which comes to mind is that if the strategies suggested in this thesis find a "fertile soil," there will be an overproduction of foodstuffs for less demand in some countries particularly in tropical Africa (Central, West and Central-East) where the climate is more favorable to agriculture, and population growth is lesser.

If considered the population growth and the exponential demand for foodstuffs associated, it can be contended that food glut in the domestic markets will not materialize any time soon. Furthermore, there exist considerable food differential in many countries (Kenya, Cameroon, Nigeria, for example) between agriculture-rich areas and marginal areas. With a better distribution system as will be covered later in this chapter, marginal areas will benefit from the surplus of agriculture-rich areas.

On international level within the region of sub-Saharan Africa, the thesis suggests that policy makers must engage in a policy of "food for economic integration" in a sense that agriculture-rich countries in the region can formally trade foodstuffs with their neighbors who have less favorable ecological conditions. Such courses of action were undertaken in the past but were not successfully institutionalized in the long run due to political differences, smuggling, and lack of organization. Such is the case of Kenya's exports of 
food crops (maize, millet and sorghum) to Uganda and Tanzania in the late 1960s within the EAC (East African Community) arrangements (Heyer et al. 1976) Another case was Cameroon exports of foodstuffs to Gabon within the UDEAC (Customs Union Area in Central Africa) arrangements. The trade unfortunately came to an end in the late 1970s after a mistreatment of Cameroon immigrants in Gabon spoiled political relations between the two countries.

In all of these cases, the trends have not reached long lasting term and have even disappeared due to political differences among these countries, lack of organization, too much government control, and most of all the drastic decline in food production. Therefore, an increase in food production within many countries could help economic integration and hunger relief in the region.

The distribution and storage of foodstuffs. Closely associated with production is the distribution of foodstuffs. The distribution system is the nerve of the marketing system for foodstuffs produced domestically as was suggested earlier. It was covered in the study of Kenya that the distribution sector was responsible for food shortages and famine in marginal areas. While agriculture-rich areas and urban centers of the country had plenty of food to waste, marginal areas were running severe shortages. Another case can be observed with the lack of distribution capability and storage of various fruits in tropical/equatorial countries in Central Africa (Cameroon, Equatorial Guinea, Gabon). In Cameroon, for example, due to a lack of better distribution infrastructures between the agriculture-rich South and the arid North, people in the North undergo food shortages when there is enough food produced in the South. ${ }^{7}$ In addition, the storage of foodstuffs is underdeveloped. Furthermore, knowledge in preservation of foodstuffs is missing. For

7 See also (Boyer and Davis 1990). 
example, there is an overproduction of fruits and vegetables during the season, but they are wasted. These products could be preserved for year round consumption and for distribution to marginal areas. Keeping fruits available year round using conventional refrigeration is prohibitive in electricity bills because other preservation methods have not been devised or canning techniques are not wide spread yet. Two aspects are of critical importance to the distribution of foodstuffs in the market. The first one is the road infrastructure and the second one is the storage infrastructure.

\section{Storage}

The storage of staple crops and cereals is an issue in sub-Saharan Africa. In tropical areas of Central and West Africa, humidity inhibits storing fresh food crops and vegetables for a long time. In other areas, storage of cereals faces insects and limited availability of storage facilities of scale.

It was covered in the case of Kenya that famines experienced in the early 1980s (due to unfavorable weather conditions and disincentives to production) followed a period of good harvest in the late 1970s. The government did not have enough storage to hold the surplus of previous years. MDCs (US, Western European countries, Australia, and Japan) have well-developed storage systems to help meet the demand in case of low harvest and consumption bumps. The government in sub-Saharan Africa should encourage private entrepreneurs to build food storage units. The government itself should maintain storage units for surplus purchased from producers. With multiplication of storage facilities and their decentralization to different urban and rural centers managed by private firms, availability of foodstuffs is hoped to increase in the markets.

The preservation of non-cereal food staples has traditionally been prohibitive in tropical areas because of humidity and the vulnerability of these staples to heat. In general with good preservation, yams, cocoyams and taro roots can last up to three months. Cassava, 
plantain, and tropical fruits (mangoes, papayas, pineapples, guavas, different oranges) usually lasts a couple of days or up to a week. Here the present model proposes a very simple solution to the preservation problem for tuber crops such as cassava, plantain, taro root, yams, cocoyams, potatoes, and sweet potatoes. Fresh products (the excess or unsold stock) must be quickly transformed into farina and stored in that form. For example, cassava tubers are pealed, crushed, ground, fermented and then dried. After, they will be ground again into cassava flour and stored or put in bags ready for food stores and local markets. Under this form cassava can last years. The other crops can be processed the same way and stored. The only tradeoff is that consumers be willing to accept these new forms of consuming tuber plants.

Like tuber plants the fruits are very perishable in humid and hot areas. Usually, it is very common to experience an excess of production of these fruits during the season and their spoiling and waste while they are absent in needed areas moreover absent the rest of the year. Tropical fruits can be transformed into jams to offset the import of expensive varieties of these commodities from developed economies. These fruits can be processed at the household level into jams and sold in local markets. In addition preservation techniques, for example, canning can help provide these fruits year long.

Small agribusiness industries with very light equipment can transform these fruits into jams, or save them in cans as it is done in India and other Asian countries. Caning techniques were also widely practiced at the household level in the USA and Europe before the explosion of the agribusiness industry. Transportation infrastructure plays a crucial role in the distribution system to carry foodstuffs in a timely and safe manner from production sites to consumer markets.

\section{Road infrastructures}

The discussion in this section calls for more efficiency in the organization of the distribution system. A key aspect of this question is the creation and maintenance of 
transportation infrastructure to bring foodstuffs from production sites to the marketing centers. Transportation infrastructure includes land, air, and water. Usually water is the cheapest, followed by land transportation. In this thesis recommendations concentrate more on land transportation because it is the most widely used. In addition, within land transportation, recommendations narrow down on road transportation not neglecting the fact that transportation by railway is cheaper than transportation by truck. However, in many cases the railway network is not widespread in rural areas where the food is produced.

Addressing road infrastructure, particularly in rural areas, the new solutions call for selective maintenance to save funds and provide more efficiency. Governments in many African countries have spent tremendous amount of their revenues from exports ${ }^{8}$ or loan money to build big roads linking cities and also road nerves connecting rural towns and localities to main roads. Heavy rainfalls, erosion, lack of knowledge, and most of all lack of capital and equipment to maintain those roads make them almost unusable after a short while.

Drawing from the example of Cameroon which is very familiar to the author and should not be generalized, the government has concentrated attention on big road axes linking big cities and medium size cities neglecting arteries from which food produced in the rural areas transit. In this model the thesis proposes a strategy that will use less funds yet provide significant help to peasants to sell their products. It will also help to distribute foodstuffs in marginal locations. ${ }^{9}$

The basis for discussion is a conceptual classification of roads which can be found similar in many LDCs of sub-Saharan Africa (see TABLE XXIX ). These roads can be

\footnotetext{
${ }^{s}$ For example, Nigeria and Ivory Coast have considerably invested in road infrastructure.

9 Animal traction should also be encouraged as it is used extensively in Asia, Latin America and Northern Nigeria to transport foodstuffs to areas inaccessible by road locations.
} 
classified into three main categories based on the administrative structure found in former French or British colonies in the region: ${ }^{10}$ (1) primary road axes linking big cities or urban centers and crossing the rural areas, (2) secondary roads from main road axis to city centers at the province or division level, and (3) tertiary roads which link rural villages, subdivision and district centers to primary road axes or secondary roads.

It has been the author's observation in Cameroon that tertiary roads are critical and often hinder peasants ability to transport their crops to the distribution centers in bigger cities. Heavy rain fall, soil erosion, flooding, or frequent tree falls are critical elements which discontinue distribution to and from remote rural areas.

Therefore, the new strategies call for selective maintenance of these roads to provide more efficient distribution system and to save funds allocated to road maintenance. Governments should concentrate more capital on full scale maintenance of primary arteries because they are nerves of communication by land between major cities and urban centers. However, for the point of view of peasants, the government should engage in efficient maintenance by attacking the problem areas on the road rather than rebuilding tertiary roads from scratch as done sometimes. This depletes capital and turns it away from necessitated investment. This thesis concentrates on sub-division and tertiary roads which are the real problem. Problem areas on secondary and tertiary roads are hill tops, bridges, swamps,

${ }^{10}$ Cameroon and Kenya were respectively colonized by France and Great Britain as the major colonial forces in Africa after W.W.II. We have found, however, a striking resemblance in the administrative partitioning of these countries into provinces or divisions, subdivisions, districts and villages. In any of the cases, colonial policy placed big colonial cities such as Nairobi in Kenya, Douala and Yaounde in Cameroon as the nexi of economic and political activity of the colony. Consequently, all transportation infrastructure converged toward those centers, some of which were often located at the coast with access to the sea. This structure has not changed much in the former colonies. It is not surprising to note that the structure of the transportation infrastructure usually is driven to these big city centers than otherwise.

A parallel drawn from transportation infrastructure in traditional urban patterns still found in some cities in Europe and North America, can also provide an explanation to the one-center structure of the transportation systems in former colonies. The most common traditional urban pattern of communication infrastructure is the once-center structure. In this structure, the city center is the hub where all traffic, economic and political activity converge. However, because of congestion and the need for decentralization or urbanization. this model is increasingly giving place to a more decentralized, multi-center urban structure in the L'nited States. 
and fallen trees. Government maintenance of rural roads should emphasize on these aspects. ${ }^{11}$ (1) repair damaged bridges, (2) provide asphalt on hills -- they are the most problematic for vehicles, (3) remove fallen trees. Maintenance of portions of rural roads that are not hills, bridges or problem areas like swamps should be left to the responsibility of villagers themselves.

Technology wise heavy trucks and lorries are the most responsible for road damages in rural areas (bridges and hills). This thesis recommends that only light trucks be allowed to transport product from villages to Division centers. All-wheel drive trucks will be able to make it easily from villages to centers as many private individuals currently do. This aspect will be expanded more in the reorganization of rural communities and the marketing system for food crops. The villages will supply their products to their Village collection point. The collection point will deliver to the Division city and from there products can be sent to big cities by train or car by food distributors. Selective maintenance can help the government save a lot of money that otherwise would be wasted as has been in some cases.

\section{Distribution of foodstuffs from production to consumer table}

A layered distribution system is proposed (see Figure 25 in Appendix B) where the producers (peasants) are kept in rural areas and only licensed distributors can have access to city markets. A layered organization of the distribution system for foodstuffs (staples and meat) matches the layered organization of the abstracted road system which matches administrative organization in provinces, subdivisions, districts, and villages.

At the upper level, i.e., big cities, ${ }^{12}$ only licensed distribution companies are allowed to retail foodstuffs from producers (rural peasants, small producers, and big producers) to

\footnotetext{
${ }^{11}$ It is our experience in Cameroon that the government tried at each time to remodel these roads from scratch and could never succeed because of limited funds. In the end the projects were often abandoned.

${ }^{12}$ In this kind of administrative organization, big city centers usually fall within administrative provinces and are "capitol" cities for these provinces. Each province is made up of sub-divisions which comprise districts. Districts comprise individual villages.
} 
retail stores, and food processing plants. Storage units must be built in big cities by these companies to store the product before distribution to small retailers. Also the government must build storage facilities for surplus production.

At the provincial or division level smaller provincial city centers will have storage facilities as well. At this level distribution companies will store the produce obtained from rural producers before shipping it to larger cities.

TABLE XXIX

\section{A CONCEPTUAL CATEGORIZATION OF ROADS IN SUB-SAHARAN AFRICA}

\begin{tabular}{|c|c|c|c|}
\hline Category & Origin & & Destination \\
\hline $\begin{array}{l}\text { Primary roads } \\
\text { (big axes) } \\
\end{array}$ & $\begin{array}{l}\text { Big city } \\
\text { (Smaller) Provincial city }\end{array}$ & $<>>$ & $\begin{array}{l}\text { Big city } \\
\text { Big city }\end{array}$ \\
\hline Secondary roads & $\begin{array}{l}\text { (Smaller) Provincial city } \\
\text { (Smaller) Provincial city } \\
\text { District/subdivision town } \\
\text { District/subdivision town }\end{array}$ & 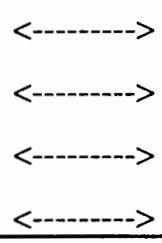 & $\begin{array}{l}\text { (Smaller) Provincial city } \\
\text { District/subdivision town } \\
\text { District/subdivision town } \\
\text { Primary road }\end{array}$ \\
\hline Tertiary roads & $\begin{array}{l}\text { Rural Village } \\
\text { Rural Village } \\
\text { Rural Village } \\
\text { Rural Village } \\
\text { Rural Village } \\
\text { Rural Village } \\
\end{array}$ & $\begin{array}{l}<---------> \\
<---------> \\
<--------> \\
<--------> \\
<--------> \\
<--\cdots---->\end{array}$ & $\begin{array}{l}\text { Rural Village } \\
\text { Secondary road } \\
\text { District/subdivision town } \\
\text { Primary road } \\
\text { (Smaller) Provincial city } \\
\text { Big city }\end{array}$ \\
\hline
\end{tabular}

Peasants and producers are not allowed to distribute food in the city at this level. The task is left to licensed distributors only. 
At the subdivision or district level, peasants can distribute their produce to local retailers directly or to licensed companies. However, at this level, peasants and small scale producers can distribute (sell) their produce directly in the local markets.

Distribution of food from production sites to marginal areas will be uniquely carried by licensed distribution companies. These companies will supply the produce to those areas at the big city nodes, the smaller provincial city centers, or subdivision nodes. However, it is preferable that the hierarchy of distribution be kept because it will help distributors gain more time and efficiency by shortening the trip that individual truckers have to cover.

The distribution of foodstuffs within big city centers or provincial city centers and subdivision of foodstuffs will be covered extensively in the following section. Also, the benefits and tradeoffs of this organization of distribution will be discussed together with the marketing system.

The marketing of foodstuffs. In the case study of Kenya it was shown that the marketing of foodstuffs was significantly responsible for the incapacity of the country to meet its food demands. In the current solutions, it is suggested that the marketing of foodstuffs be completely left to private entrepreneurship. The government must intervene only to set standards and prices in collaboration with producers, distributors and consumer representatives. Pricing policy because it involves more specific microeconomics and macroeconomics considerations will not be addressed in this thesis. However, it was suggested in CHAPTER IV that pricing policy must be balanced to provide incentives for producers to stay in the food production business and consumers to have food at reasonable prices compared to their income.

The organization proposed for foodstuffs marketing (see Figure 26 in Appendix B) closely espouses the structure of the layered distribution system. The marketing system comprises three layers: (1) the producers (peasants, other small producers, and big 
producers), (2) the licensed distribution companies, (3) the licensed retail companies, and (4) food stores and small shops in urban centers. A general remark is that food marketing on scale in big cities and primary provincial city centers is carried by licensed marketing companies and shops only.

The peasant producer at the village (small town) level

This model recommends the replacement of inefficient government-controlled cooperatives by small agriculture firms, the "peasant food production firms." Each village would have their state registered agricultural firm. Each peasant member of the firm sells food products through that firm and receives revenues according to his/her share of the input product as in any other capitalist enterprise. This means simply that the benefit share is proportional to individual investment in the firm. The concept of the "peasant food production firm" is different from a cooperative in a sense that it is nationally registered as a firm, and its members associate on the basis of proportionality of returns based on one's share of initial capital. Each villager member of the firm may subcontract his farm produce to the village firm.

The authorized distribution company purchases foodstuff products from these firms for sales to city consumers or to agribusiness industries at the price fixed by the state. Villagers who are not members of the village firm can market their products directly to consumers at the district center market or sell it directly to retailers or distribution companies at prices fixed by the state.

The village firm may be responsible for transporting the product from the village to the district or subdivision center where it is sold to distribution companies. In turn firm members will buy their provision of necessities from the stores at that location to furnish their small shops in the village. Transportation of food products from the village to district or subdivision centers must be done with light ( $4 \times 4$ preferred) trucks to avoid damaging 
tertiary roads. The village firm can obtain a loan from the state or major banks to purchase a light truck for transport of their produce. The truck will of course be the property of the firm. The notion of private property needs to be stressed and enforced by law.

\section{The district or subdivision level}

Distribution and retail companies can have their stores to retail products at the district center. At this node thcy can have storage units for the produce ready for pick un and delivery to cities or other areas in the country. At this level, popular markets can be left to function because they do not cause significant congestion and garbage problems. The popular food market is necessary at this level to keep the psychology of the community which is stronger in rural areas and areas close to rural areas. Conversely, in big cities the purpose of the food market is no longer necessarily a medium of socialization, rather an impersonal resource collection base. They create congestion, non-hygienic handling of foodstuffs, and garbage problems.

A regulation should impose that villages in a given radius outside the center of the district or subdivision only be allowed to sell their product though their "village firm" to the distribution companies or retailers at that district center.

\section{At the provincial city (or big city) level}

At this level only distribution and marketing companies or retail stores are licensed to sell foodstuffs. The distribution companies supply retail stores and shops with the produce from their distribution centers located in the city. At this level, the village firms within the vicinity of the city can be allowed to sell their product to licensed distribution companies only. Also, popular food market will disappear progressively because distribution and marketing of foodstuffs is only carried trough licensed companies or stores. A big social consequence may arise from the demobilization of a cohort of women and small retailers 
who make their living from these popular markets. It will be covered in the discussion of solutions how these retailers can stay in food retail business by organizing into small food retail enterprises.

Development of rural economies: decentralization. Based on the transition from agriculture sector to manufacturing in industrial countries, it can be supported that the phenomenon of rural exodus toward city centers can be abstracted to three categories of reasons. First, people go to cities to find jobs in the manufacturing, service, or government sector to increase their income compared to what they make from the land. Second, people move to the cities because agricultural activity does not provide them anymore with the needed income and vital resources to sustain themselves. ${ }^{13}$ Third, others go to cities for necessities such as better education and health, or to purchase commodities not available in rural areas, or just for the attraction of the "modern."

In any case the phenomenon of rural exodus has deprived rural areas of needed labour force to produce food. Traditionally rural areas had enough manpower to help women produce food. The rural exodus to cities is partially responsible for the actual incapacity of rural areas to keep production levels that satisfy the demands of the fast growing population in urban centers. In current times, cities are full of unemployed people who are a dependency burden to their working relatives. With the wide economic recessions and heavy downfall in some countries, many people have been laid off after the closing of foreign or state-owned companies.

If given more economic incentives in the rural areas through agriculture production and agribusiness industry, unemployed people in the cities could flee misery to come back to live a better quality of life in the rural areas. Such a move calls for a decentralization of economic activities to develop rural areas. This model tries to answer that question from

\footnotetext{
13 This applies also when they are landless, or cannot do squatting or labor for others in return for pay.
} 
the viewpoint of food production. As mentioned earlier, the crucial issue lies in providing incentives to food producers, especially those incentives designed to empower women and to draw men from the declining cash crop activity (especially cocoa) into food production and agribusiness. These incentives can be obtained from decentralization and the reorganization of rural communities.

At the lowest level, the rural village, the model addresses the reorganization of the peasant community around food production activity. The village should be organized to provide to the maximum self-reliance. The benefit of this strategy would be to provide basic needs to people living in the village. What this means is to give incentives to people to own a small shop in the village for household basic needs such as kerosene, salt, sugar, non-prescription and first aid medicine, agriculture tools, school material for children, etc. These necessities can be supplied by distribution companies on their way to collect food product.

As food production is concerned associations such as the "yum" which have in the past boosted individual food production, are recommended. The "yum" (found in Cameroon) is a traditional association of villagers to provide workforce to members of this association on a rotation basis. The benefit of this association was to increase production of each individual producer (the cash crop farmer, or food crop producer) by providing enough labour for clearing the farm or tilling the earth to plant crop seeds. However, the increase in cash crop activity and the penetration of money economy destroyed these forms of selfsustained associations which helped production and kept the village community tight together. This is predicted to happen because capitalist penetration destroys traditional forms of production and community associations to replace them with individual drive to make more profit. ${ }^{14}$

14 In a study of the impact of the money economy on social relations of the Mambwe tribe of Northem Rhodesia (current Zimbabwe), Williams Watson (1958) has found evidence that capitalist mode of production and the penetration of money economy had a serious impact on traditional bonds of native societies in the non-Western world. The Mambwe tribe before colonization, had land as their only resource 
Also traditionally, each household in the village raised a small livestock (goats, sheep, cows, pigs, chicken, and other) for protein base. This provided a self-reliance on protein base. However, to the exception of sahelian areas where nomadic pastoralist still practice livestock farming, in general livestock self-sufficiency of the past has given way to increased hunting for wild meat or supply of meat and fish from city centers. Without significant source of monthly income, peasants in rural areas face a serious crisis of in protein supply. It is not foreign that children and adults lack enough protein to enrich their nutrition. Therefore, this model recommends that at the household level, each family have their own minimum livestock in addition to what they sell.

Other sources of protein can be obtained from "meat product farming." In many African countries (as opposed to the Western and Asian countries), people have remained historically reliant on nature to provide them with resources and have not necessarily learned to rebuild nature (although they consumed natural products with restraint). Historically, with the small population and the lack of huge market demand, consumption of natural products such as fish, water animals (alligators, crocodiles), and wild meat was minimal, which gave nature time to reproduce. Now with commercial demand from urban centers, especially middle class need for delicacies of wild meat, many species such as antelopes, porcupines, wild pigs, monkeys, chimpanzees, gorillas, rhinoceri, etc., have been drawn to near extinction without any significant effort to reintroduce them in the 
forests and savannas. ${ }^{15}$ This thesis recommends that fish and water products be farmed in creeks and ponds in the village. For example, natural water retention ponds (such as proposed earlier in this chapter) and village creeks can be used to farm small river fish, shrimp, crabs, alligators and crocodiles. All these products will provide more sources of protein to the villagers and help save wild animals from excessive hunting and trapping.

Another significant organization is the political one. Traditionally each village had a chief and elders who solved disputes, and assumed leadership in the political structure of these communities. With modernization, a village chief recognized by government authorities of the district or the division has been responsible for tax collection, solving minor disputes, and reporting to higher authorities. However, in the food production or sometimes in cash crop production activity, villagers seem to resist the advice of "experts" sent by the government, especially in areas where they have accumulated centuries-long experience or field experience on their "own" environment. The result of this is not only the waste of government efforts by deploying agricultural aides, but sometimes misguidance of the villagers. What is suggested here is to train a local person in the village to be the "expert" on new methods. This will make it easier for agriculture experts of the

base (with no individual ownership) for living. With the market penetration, they faced a new mode of production: work and wage earning from the mining industry. As tribesmen moved to the money economy, the traditional solidarity among the people in the village disappeared progressively to give way for individual search for money.

A parallel can be taken from this example to justify why traditional associations such as the "yum" in Cameroon disappeared with increased penetration of the money economy particularly cash crop economy in peasant societies. Jalousie which is frequent in traditional societies can be considered as an explanation to support the impact of market penetration on peasant societies. It can be considered that jalousie increased as some people earned more money than others on cash crop or food crop sales to cities. Therefore, others were no longer willing to give time to common activities were beneficial to each one.

${ }^{15}$ Only since the late 1980 s when conservation movements around the developed world rang the bell on endangered species and the need for their preservation, have governments in LDCs embarked in an effort to save these endangered species. Such efforts have been notoriously successful in Kenya and Zimbabwe with the preservation of big mammals such as elephants, rhinoceri, big cats, chimpanzees and gorillas. However, not so much is done for smaller species such as monkeys, antelopes and other which are hunted extensively for meat.

The three last categories (gorillas, chimpanzees, elephants, rhinoceri or big cats) were hunted by poachers for skins, body parts and ivory often on payroll by foreign smugglers. 
Ministry of Agriculture to teach new methods. The rationale behind this approach is that historically and by experience more traditional societies rely on kinship relations and have proved to be more efficient than their modern counterparts in this respect. This kind of political organization is suitable for the results sought in this thesis, i.e., a sustainable food production sector, a more robust development of rural economies, and a successful restructuring of rural communities to provide amenities for peasants to stay in rural areas. The layered distribution and marketing systems cxposed offer a more efficient, fruitful, and less costly way for villagers to market their foodstuffs to urban consumers

\section{DISCUSSION OF THE BENEFITS AND TRADEOFFS OF THE NEW STRATEGIES}

The model presented in this thesis is a market economy model with only limited government intervention namely in shaping a national food production policy, catalyzing private entrepreneurship in food production, setting and enforcing prices, monitoring the respect of regulations such as (1) restrictions on the distribution and sale of foodstuffs to non licensed individuals or companies, and (2) enforcement of traffic limitations on rural roads. (3) sanctioning non-licensed food retailers in the city markets.

The benefits of these strategies have been discussed. Overall, the new system will help the transformation from subsistence food production to an agribusiness food industry. Therefore, the new model can serve as a starting point for the transformation of these economies from purely agricultural to agribusiness, then to manufacturing sectors. It was seen that big distributor companies or producers (village firms, or large scale producers or licensed individual entrepreneurs) can build food processing plants in the secondary localities near the food production centers as done in the US. What results from this is an opening of new jobs in the rural areas to employ those who do not own land or are not employed in food production. The benefit of this is economic decentralization and 
development of rural economies around what they produce best -- food. The current solutions embody some tradeoffs that are not necessarily beneficial or feasible in the short term. Each area of solution (production, distribution, marketing) is investigated in the following.

Production. Food production indeed can be the node of a sustainable development as it has been in history for industrial countries. Development can be considered as a multifaceted endeavor which can take its starting point from any basic need (food, education, shelter, health) then develop in concentric circles each adding and expanding, including or opening new sectors as diversification of the economic activity increases with the needs ${ }^{16}$. An example of this was the agricultural sector in the United States which, with the development of the agribusiness industry has brought a host of techniques, plants, manufacturing needs, and has helped the growth of other sectors such as the manufacturing sector and the biochemical industry (plastic industry, bottling and canning industries, irrigation industries, tractor and tools industries, and other.) It could be the same case for sub-Saharan African countries to focus their development on food as basic need. Other sectors could develop because of the needs of the food production sector. Then in concentric circles a sustainable development centered on basic needs can be attained which fits the environment, culture and economic capabilities of sub-Saharan countries.

In a simplified abstraction, the layered distribution model and marketing presented in this thesis look much like the models in the US and other developed economies. However,

16 See also (Amin 1990). In this sense the advice of Western policy advisers has been to specialize more efficiently in what they produce better -- cash crops. However, this thesis joins Amin to contend that such an advice creates outward oriented development and does not necessarily help people meet their basic needs. We support that any sound development for LDCs in sub-Saharan Africa should emphasize selfreliance in food production.

The success of this type of program needs wide popular support in order to defeat the economic forces which tend to keep the statusquo in favor of the internal bourgeoisie (political and economic elites) and external economic interests. 
the model has mixed both the market economy and the peasant economy without drastically destroying the latter. With the development of agribusiness, many small producers will get out of the business. Peasants will be smoothly transformed to wage earner in the agribusiness or in the developing manufacturing sector. Therefore, the transformation from agriculture to industry will happen progressively.

This model is robust because it accommodates both rural and modern. It combines peasant economy with modern market economy, therefore, it may help decentralization of economic activity to rural areas. Politically, the model imposes no coercion on the peasantry and may reduce the black market because competition is open. Domestic economy can be improved based on the food sector provided imports of cereals are discouraged.

The model presents no imposed painful and politically dangerous land reform which has failed in many countries in the Third World where ethnicity is high. In addition, the new strategies place government's role as regulator and catalyzer of private entrepreneurship rather than controller or producer. If this model is implemented and takes firm root, it may require a robust and diversified banking sector to provide loans to producers and distributors without negative intervention of the government. Finally, the model opens a way for services and new jobs in the agribusiness industry. In addition the expansion of the agribusiness industry and its needs in equipment and tools will trigger an improvement in domestic skills within the manufacturing sector.

Distribution. The layered distribution system because it reduces long journeys saves money and products. In addition when combined with the layered marketing structure, it will tend to keep peasants within rural areas. An adverse effect is that it will need a lot of enforcement. therefore, state funds to institutionalize such a system. However, education of the peasants on the benefits of such a system may help gather support for the 
implementation of such a system. Also, this model implies development or rural communities so that peasants can have amenities to stay in rural areas. Therefore, maintenance of hospitals, roads, and provision of other services such as credits and loans to these villagers through their agricultural firms can help keep them in rural areas where they are better off than frequently coming to cities. Also, marginal areas will be able to benefit from surplus of agriculture-rich areas. On the storage of foodstuffs, if new preservation techniques are carried at small scale, many fruits, vegetables, and meat will be preserved to provide more food for local markets.

The overall benefit is that the whole distribution system is a sort of relay system on pick up delivery schedule. Therefore, a lot will be saved on transportation cost and time related to far-reaching vehicle trips. Distribution vehicles, at the exception of trains (which usually link big cities), will be confined to a given layer except when they transport food to marginal areas. Therefore, efficiency is added to the distribution system and bottlenecks can be easily removed.

By confining bigger tonnage vehicles to primary and secondary roads only, rural roads will be protected from frequent damages caused by these vehicles. In addition, the layered distribution system imposes that transportation of foodstuffs is done in short distances (between two supply centers) rather than on very long distances (except distribution to marginal areas very far from agriculture-rich areas.) With this layered arrangement, efficiency in schedule and preservation of the product can be achieved. A problem may come from the enforcement of these regulations on tonnage and respect of distribution layers. However, if the activity is made competitive, distribution companies will find necessary to enforce these regulations upon their workers. The reason is that with a tight licensing of distribution companies, it is easier to identify the violators. Also in a truly competitive system, other companies will reduce social cost by exposing the violators in order to preserve the good working state of the system on their benefit. 
Marketing. Many advantages can be gained from the marketing system exposed in this thesis. As the distribution system, a layered market system will be more efficient in meeting supply schedules in time and space. Also the producers have a better chance to gain better benefits from their produce with such an organization. The system is discussed from (1) the view point of the small producers (peasants), (2) distributors and retail companies, (3) the small market retailers in the cities, (4) urban consumers, (5) the cities and the system as a whole.

\section{The peasant producer ${ }^{17}$}

The benefits to the peasant are many, three of which will be discussed here: benefits related to the "peasant food production firm", benefits of the layered distribution system, and benefits of the layered marketing system.

The "peasant food production firm" protects the individual farmer from distributors who routinely purchase products at very low prices or rip off poor peasants who do not have the means to sell their products to the cities at more competitive prices. Therefore, through the firm the peasant would be assured of the return from his product. One could argue that this would not solve the problem because food distributors could take advantage of the villagers' lack of means to go to cities in order to rip them off. Although competition among food distributors would tend to reduce producer prices, it would favor the peasants because they can choose between many buyers. In addition, strictly state imposed and enforced price levels would prevent price drops below allowed limits as a result of competition among producers.

\footnotetext{
17. We have not covered big producers. However, it is implied that because of their large market share compared to small producers and resources at their disposal, these producers can be at the same time distributors of their produce provided they be licensed by the state. Big producers have latency to sell their product wherever they like provided it be either to grocery stores or to licensed distribution companies.
} 
Another difficulty is that some peasants in the village would initially tend to go alone to have more benefit by selling to the highest bidder of their choice, or to make fast money to respond to an immediate need. However, this one producer would lack bargaining power vis-a-vis of the more powerful buyer and will discover the disadvantage in the long run. To solve immediate financial issue, the "village firm" will have an account to provide small, yet controlled loans to each villager member of the firm. The village firm can also provide a health insurance to cover part of the medical bills of firm members and their family. This host of advantages will immediately discourage people who want to go on their own, without imposing control on them as the cooperatives did with disastrous results (lack of motivation and inefficiency).

A question to answer is how to stop black marketing? Since the current system is not imposed to anyone and that there are many potential benefits to the participants, this will not cause any significant tendency towards black marketing. Organizationally speaking, villagers will organize their firm either on modern structures of a capitalist firm or on the lines of their traditional organizations. However, the market competition characteristic is kept.

Another question is "how if villager wants to go to the city to sell his product at higher bid?" Tight government regulations would forbid and sanction any villager from selling products directly in a popular market in the cities. They can only sell their product at the district or subdivision level to licensed distribution companies. Only the latter should be allowed to sell the product in the cities.

Peasants will be left with less incentives to come to the cities to sell their products. With more basic need stuffs available to them in rural areas, they would be able to go to the cities only to visit their relatives, or for vacations, or medical needs and others. It will save them a lot. Traditionally peasants, especially women have often embarked in long journeys to cities on dangerous roads, on the back of trucks with crazy drivers. They often get ripped 
off for transportation costs only come home with small leftover income from the sales. In addition, for those who do not have relatives in the city, it means cold nights outside in the local market with babies in their arms, under threat of theft, rape and murder, and nonhygienic conditions in the dirty local markets. With the retention of peasants assured in the rural areas, the latter will be able to invest their money to buy products in the local economies in the rural areas which will boost these economies. At this moment peasants have been going and spending all their money in the cities, depriving rural areas of capital accumulation. With the present model, peasants can save money and time wasted on long trips to urban centers.

The strategies proposed require a popular education through the sort of "popular movement" suggested by Amin (1985). Mass education of the peasants about benefits of such a system can, better than a coercive dictatorship, help for the implementation of these policies. When the masses are educated enough on what these solutions can bring as a positive contribution to help satisfy their basic needs, they may join in easily. This remark calls for its opposite, i.e., if not enough "popular education" is carried out, these strategies may not find a fertile ground at all.

\section{Distribution and retailer companies}

The agribusiness companies responsible of buying the products from village companies or small town companies, could diversify their activities by opening stores in the rural areas for manufactured products and other necessities. On their way to pick up produce from production areas, they can transport these necessities to rural areas. A layered distribution system is more efficient because not only it will make the trip of the producer shorter, but it will also save the perishable products from sunshine. An overhead may come with the handling of products at "relay storage point." However, with better packaging there will be less problems. In general, electrification in many African countries has reached most rural 
subdivisions and localities. ${ }^{18}$ Therefore, storage houses air conditioning can be built there from which trucks can pick up the product to sell it in the cities. The big retailer or distribution company will just have to make the trip from big city to the Division or district center. They can also own credit banks to provide loans to village firms from which they subcontract foodstuff products.

\section{The small retailer in city markets}

It was suggested earlier that with the current system, spontaneous popular markets would progressively disappear in the cities to give way to food stores, supermarkets, and shopping centers. However, the cost is that a host of small food retailers, particularly women would be put out of business, depriving them from the source of income to support their families. A solution to this problem is that those retailers who cannot afford selling in supermarkets can open their own stores in residential areas provided they obtain a license from the state. However, a better solution is that the women can organize as retailer firms or as shop owners to purchase and sell products. The firm will employ each member and hire other workers in the provision of services. The workers will be paid on hourly basis and based on the minimum wage imposed by the state. Revenues will be deposited in the firm's account at the end of the day or at the end of the week.

Sale of foodstuffs in grocery stores is beneficial to consumers in a sense that it is more clean. occupies less space, and causes less congestion of the streets and garbage problems. In addition, popular markets usually close with the fall of day light while shops and grocery stores can be kept open on 24-hour basis to provide needed food to consumers. Also, decentralized shopping centers around the city will help reduce congestion and transportation hassles to get to the few popular markets in the city.

\footnotetext{
${ }^{15}$ Even for countries with less electrification, what will change is that the route between production areas and the nearest "relay storage point" will be longer. The layered distribution system can still be maintained.
} 
The disappearance of popular markets will also affect other ambulant merchants and small retailers. As for the food retailers, these vendors can associate to co-own shops or retailer enterprises. In general the popular food market is the one that drives the creation of popular markets. With its transformation into shopping centers or shops, the other vendors of necessities are expected to do the same.

\section{The urban consumer}

The consumer in the city benefits from variety, quality and supply schedules. In addition, the consumer will benefit better prices that can be controlled more closely by state regulations. As pointed earlier, one benefit of the transformation of popular food markets into grocery stores is that the food can be made available 24 hours a day in shops and food stores, clean, and competitive. Also, an increase in food production and organized competition will certainly bring prices of foodstuffs down to benefit urban consumers. They'll be able to save on income for other life investments.

A question to address is that some city dwellers may find it cheaper to buy foodstuffs from farmers and peasants. It is normal, even in the US it is done so. However, the more the distance to the farms, the less the incentive for individuals to engage in such a practice because the cost of the trip in time and transportation may offset the benefits.

\section{The cities and the rural areas}

The system presented will benefit the cities by providing more foodstuffs (quantity, quality. and variety) in the market at a price affordable to consumers. In addition, if the strategies are successful, some level of de-congestion of the cities will follow with more people settling in the rural areas. With the transformation of popular food markets the city gains in cleanliness and a new type of infrastructures, food stores and shopping centers which are more controllable and may provide jobs to the unemployed in the service sectors. 
The reorganization of food production in rural areas and the growth of the agribusiness industry proves on abstract that development of rural economies and decentralization are achievable with the food production sector of the economy. Furthermore, the strategies have suggested a way of reorganizing rural communities around food production which may give incentives to people to stay in these areas when their basic needs are at reach.

The strategies have proved also that the long sought decentralization of economies in sub-Saharan Africa is possible with development of the food production sector, particularly the agribusiness industry. Some questions are yet to be answered which have not been discussed in length in this thesis: resistance of policy makers in developed economies, internal corruption, pricing policy for foodstuffs, regional integration with the trade of foodstuffs within the African continent.

Unanswered questions. This model has called for a curtailing of food imports from developed economies. Yet in the short term a food gap may occur unless gradual curtailing is conducted. Also, the dilemma is that the economies vow to be market-oriented and at the same time this solution is nothing but government control of economic activity. However, it is legitimate in trade and economic policy for any country to protect its domestic industry from external products by applying judicious tariffs. All MDCs practice this policy for manufactured products and for agriculture products (CAP policy of the EEC, and US agriculture trade policy). It is legitimate to curtail imports of foodstuffs, but the decision makers must conduct it in a way that will not cause food gaps while the food production sector is picking up.

In addition, it was covered in CHAPTER IV that imports of foodstuffs benefit the farmers of the North, politicians and businessmen in the South, but not so much the consumer or the country's self-help in food production. Therefore, curtailing of imports is likely to meet resistance from developed economies. It is here that Amin's "popular 
movement" must come into play to preserve progressive governments in sub-Saharan Africa from external pressures. By gathering national consensus on such inward-oriented development strategies, negative external influence to maintain the statusquo may be contained. In this sense, democratic governance seems better placed to achieve such a goal. Decision making should no longer rest on the President alone or a corrupt political elite vulnerable to external pressures, but on a "Congress of the People" who will easily contain external forces, and mitigate corruption and other government bottlenceks.

Another issue is government corruption that will have a negative effect on the enforcement of regulations and setting of prices. However, it is hoped that if the enterprise is private, that private forces will coerce government officials to lessen corruption. Also, with a "Congress of the People" and "popular education" on these strategies, corrupt government practices will be exposed and combated by the private sector.

Also governments must play a key role in catalyzing private entrepreneurship in food production and limiting food imports. Governments must stop playing the role of "do-itall" controllers and bottlenecks and become regulators and catalyzers of economic activity particularly in the food production sector. A sure way to succeed in this effort will be to give leadership of this food program to women. They have done it so well for centuries, they will be willing to do it again. It will provide them with more power and more economic independence vis-a-vis of their husbands. Also, in the cities, the agribusiness will bring jobs to women and allow them to raise their kids and support their families by working in the food service sectors.

The issue of subsidies to food producers and distributors has not been addressed in this thesis. It is implied in food production that the government must provide subsidies to producers to keep them in business and to cover losses due to bad harvests, a high cost of production inputs, capital machinery, and other expenses. As for pricing policy, this issue 
is not in the scope of this thesis. Another area, the inter-regional trade of foodstuffs among African countries has been mentioned and suggested but not developed in detail.

Nonetheless these prospective limitations, government leadership and popular education on these new strategies are a key for their success. The conceptual model of new food production strategies has provided a path which sub-Saharan African countries can follow to make a transition from agriculture to pre-manufacturing economies with solutions that do not originate from foreign advisers, but from inward-originated and inward-oriented solutions. 


\section{CHAPTER VI}

\section{CONCLUSIONS}

The food crisis in Africa in the 1990s is exacerbating. The present research has made evidence that the causes of the crisis are rooted in the economic policies of sub-Saharan African countries, inherited from colonial legacy. Such causes can be summarized in the fact that the economies of sub-Saharan Africa are mostly export enclaves of cash crops and raw materials to MDCs. Henceforth, facing the shortage in needed capital and foreign exchange, these countries and Western advisers have insisted on exporting more cash crops and raw materials. Other countries of the region have resorted to expensive ISI, but have lacked a domestic or regional market to sustain it. The consequences on the food production sector have been the decline in domestic production and the increase in food imports that add to the debt burden. Furthermore, harsh climatic conditions (prolonged droughts) add to the backwardness of agricultural technology and methods to cause poor output of food production and inability of the food production sector to catch up with the fast growing population.

Kenya figured in the 1990 s as a country facing severe food problems. The food production, although it was kept constant, faced fast population growth and unfavorable climate as two dilemmas which set back the ability of this sector to satisfy domestic demand for foodstuffs. As a consequence Kenya has been for more than a decade, a net importer of foodstuffs in the form of food aid and commercial imports. 
An investigation of causes for Kenya's food gap reveals six major reasons: (1) Structure of Kenya's economy as agriculture and commodity exporter set up during the colonial period, (2) Government neglect of food production sector to emphasis on cash crops, (3) Flawed government policies (poor production methods and technology, marketing, distribution, pricing), (4) Population growth, (5) Natural ecology of Kenya, (6) Structural barriers set by international economic institutions which allow the Kenya Government to take the easy solution of food imports (GATT, CAP \& US agriculture policies) rather than encouraging stronger domestic food production.

A historical study of Kenya from the colonial period and subsequent governments after independence has attributed responsibility of politics to the food crisis. During the colonial period, the state favored the settler's cash crop economy and denied resources to Africans for both cash crop production and food crop production. Settlers agriculture provided the backbone for the agriculture economy. The confiscation of land to the benefit of settlers left Africans without means of food production. Colonization destroyed African food production with confiscations which aimed at forcing Africans to modern economy (for example, destocking of Kamba cattle). Even the land reform of the Swynnerton Plan favored cash crop production and gave larger lands to the African elites. The majority of the population got just small lots of land which couldn't produce much output.

Until 1944, all the institutions of the colonial state were closed to Africans (Legislative Council, Central Government, Provincial Administration.) Africans were subjects and were denied participation in politics. Therefore, they did not have a voice to express their needs for food production. Discontent over land alienation and repression of African voice gave way to the Kikuyu-led Mau Mau rebellion in 1954.

In modern Kenya, politics were found responsible as well for the food crisis particularly on resource allocation, governance, and political institutions. At the 
independence, land bough back from the settlers was unevenly distributed to the elites and Jomo Kenyatta's Kikuyu group benefited the most.

The structure of the Government since Kenyatta shows no participatory institutions, rather institutions that are directed by the President himself or the elite. Political institutions (Government, National Assembly, and Local Government) are mostly centralized. The political rule has been mostly authoritarian and has not allowed free citizen participation with agendas that divert away from the elite agenda. In other words, the agenda of national policies has been often set at the discretion of elites. As an illustration, Kenyatta embarked on Kenyanization of the economy, education, cash crop economy and attracting foreign investment (MNCs) as his own policy vision. The food production sector was not given enough attention. Furthermore, it can be argued that heavy investment in rural infrastructure, education, health and a large civil service during the Kenyatta era has taken away large amounts of scarce resources that could have benefited the food production sector.

Arap Moi followed Kenyatta's footsteps. However, the crisis of governance and allocation of state resources worsened with his regime. Huge military spending, large police force for repression, and tribal politics favored his ethnic group and stole away more resources of the state. In addition, the political institutions have not changed in their authoritarian character and their domination by the President. During Arap Moi's regime, the Government has also been unsuccessful to curb population growth by stronger birth control policies. As a result, food supply has lagged far behind in matching population growth.

Structural Adjustment Programmes imposed by the IMF and World Bank have further penalized food production by forcing the government to remove subsidy to rural farmers. Women particularly have been denied access to resources with this adjustment. This host 
of reasons prove, in the Kenyan case, that the politics have significantly contributed to the crisis in the food production sector.

A sound solution to the food crisis as recommended by the present research is to devise development strategies in sub-Saharan Africa to boost food production. To do so, there is a need for governments to give incentives to rural farmers and small scale producers to produce food. Women who produce $80 \%$ of the food consumed locally fall into this category. Particularly, incentives must be devised to draw a large segment of the unemployed population of men and cash crop farmers to food production activity. Such a goal can be achieved by rendering the food production business more lucrative with the development of a better marketing and distribution system and an agribusiness industry.

This thesis has offered a conceptual model for production, marketing and distribution of foodstuffs. The model is robust in a sense that the solutions offered are simple, affordable and inward looking, that is, they require almost no reliance on outside help for their implementation. Also, the model presented provides a possible way to solve two other crucial problems in sub-Saharan Africa -- development of rural economies and their full integration with urban economies, and national economic decentralization, and regional economic integration through trade.

Some level of improvement in technology and farming methods is necessary for an increase in the yield. Therefore, there is a need to provide the traditional farmers with some equipment adapted to their environment and means to alleviate human labor. Technical education should be tapped to invent new equipment that is adapted to the needs and the buying capacity of the rural peasants.

For the implementation of the proposed strategies to work, it is vital that governments in sub-Saharan Africa curtail imports of cheap food from agriculture-rich countries. 
Particularly they must discourage citizen reliance on imported cheap food and to force them by the same way to look inward for solutions to their food needs.

As for the case of Kenya, there is a need for improvement in political governance to provide democratic political institutions that allow people to participate in the decision making process. In the case of food production, food farmers must be given a voice through democratic political institutions to express their need for resources to produce food. Particularly, women must be given more access to resources (loans, land, and equipment). These institutions will also be a check-and-balance for the government so that allocation of scarce national resources would go to the real needs of the people, rather than in private pockets of leaders, luxurious palaces, huge police and weapon purchases to protect the undemocratic regime. This thesis supports the establishment of a "Congress of the People" such as the American Congress as an institution well-indicated to achieve this end. The existing National Assembly in Kenya and other African countries (Cameroon, Gabon, Zaire as examples) fails to meet this objective because it works on the whim and word of the President. There is practically no balance to presidential power in decision making.

Some problems remain to be solved. Those are, for example, food preservation identified as one of the causes of poor food production output in Africa. Another problem is the lack of research for high yield species that are more sustainable to the environment as opposed to those imported from laboratories of the North. This thesis has called for allocating more Research and Development in these areas so that the expected results can be met.

If development strategies are well reformulated to give priority to food production for local needs and regional economic integration in the continent, the African food crisis could 
be overcome by the beginning of the next century. Side benefits for such a policy move are many. First, an increase in domestic savings may happen from cutting imports of expensive foodstuffs from abroad. Second, progressive regional economic integration in Africa can occur based on trade of foodstuffs between agriculture-rich countries and less advantaged countries. Third, it is possible to create a solid foundation on which a sustained small scale industrialization that is nationally owned can grow from. The beginning of such industrialization could be agriculture-based to satisfy the needs of food production and the agribusiness industry.

Future work in continuation of this research will focus on drawing a full policy recommendation applied to one specific country in the region. Conceptual strategies proposed in this thesis will be backed up with quantitative data analysis and surveys on the field. 


\section{REFERENCES}

Africa Recovery, Vol.6, No.1, April 1992. United Nations Secretariat.

Aguilar, L. E. (1978). Marxism in Latin America (Revised Edition). Philadelphia:

Temple University Press.

Ake, Claude. (1978). Revolutionary Pressures in Africa. London: Zed Press Ltd.

Amara. H.A. and Founou-Tchuigoua, B. (1990). African Agriculture: The Critical Choices. New Jersey: Zed Books.

Amin. S. (1973). Neo-Colonialism in West Africa. New York and London: Monthly Review Press.

Amin. S. (1976). Unequal Development. New York and London: Monthly Review Press.

Amin. S. (1985). Delinking Towards a Polycentric World. London: Zed Books.

Amin. S. (1990). Maldevelopment: Anatomy of a Global Failure. London: Zed Books.

Bates. R. H. and Lofchie, M.F.(1980). Agriculture Development in Africa: Issues of Public Policy. New York: Praeger Publishers.

Berg. R. J. and Whitaker J. S. (1986). Strategies for African Developmentt. California Berkeley: University of California Press.

Berg-Schlosser, Dirk and Rainer Siegler. (1990). Political Stability and Development: A Comparative Analysis of Kenya, Tanzania, and Uganda. London: Lynne Rienner Publishers.

Berman, B. (1990). Control and Crisis in Colonial Kenya. Nairobi, Kenya: Heinemann Kenya Limited.

Boyer. Neil A. and Davis G. Carlton .(1990). Exploitation and inefficiency in Cameroon food marketing systems - myth or reality?: some evidence from the West Province.

The Review of Black Political Economy, Spring 1990 v18 n4 p69 (29).

Cardoso, F. H. and Faletto, E. (1971). Dependency and Development in Latin America. Los Angeles: University of California Press. London: Zed Books.

Cheru. F. (1989). Silent Revolution in Africa: Debt, Development and Democracy. London: Zed Books.

Chilcote, R.A. (1990). Comparative Politics, the Search for a New Paradigm 
Christensen, C.; Dommen, A.; Horenstein, N.; Pryor, S.; Riley, P.; Shapouri, S.; and Steiner, H. (April 1981). Food Problems and Prospects in Sub-Saharan Africa. Foreign Agricultural Research: Report No. 166. United States Department of Agriculture.

Davidson, Basil. (1989). Modern Africa: a Social and Political History. Second Edition. New York: Longman.

Delf, G. (1961). Jomo Kenyatta : towards truth about "The Light of Kenya". Garden City, N. Y. : Doubleday.

Duignan, P. and Jackson, R. H. (1986). Politics \& Government in African States 1960-1985. Stanford, California: Hoover Institution Press.

Eicher, C. and Witt, L. (1964). Agriculture in Economic Development. New York: McGraw-Hill, Inc.

EIU. (1991). Country profile, Kenya. EIU, the Economist Intelligence. London, U.K.

FAO. (1986/87). World Food needs and availabilities 1986/87. Food and Agriculture Organization of the United Nations, Special Report, pp. 88-89, 1989.

FAO. (1992). Food Supply Situation and Crop Prospects in Sub-Saharan Africa. Food and Agriculture Organization of the United Nations, Special Report, September 1992.

Frank, A. G. (1967). Capitalism and Underdevelopment in Latin America. New York, Monthly Review Press.

Frank, A. G.(1969). Latin America: Underdevelopment or Revolution. New York, Monthly Review Press.

Frank, A. G.(1979). Dependent Accumulation and Underdevelopment. New York, Monthly Review Press.

Gaddis, J. L. (1982). Strategies of Containment: A Critical Appraisal of Postwar American National Security Policy. New York: Oxford University Press.

Gilpin, R. (1987). The International Political Economy of International Relations. New Jersey: Princeton University Press.

Gladwin, C. H. (1991). Structural Adjustment and African Women Farmers. Gainsville, Florida: University of Florida Press.

Hanley, C. J. (Feb. 23, 1993). Ethiopians glad to plant again, but soil's tired: with 10 million more people to feed, the country simply can't grow enough and will continue to need outside help. The Oregonian, Tuesday, February 23, 1993.

Hanley, C. J. (Feb. 22, 1993). Somalia's pain universal thing for Africans: The goal of self-sufficiency is very faint as droughts, wars and lack of supplies take a devastating toll on the continent. The Oregonian, Monday, February 22, 1993. 
Haynes, R. W. (1991). Changes in Timber Supply in the Pacific Northwest. PNW Research Station.

Haynes, R.W. (1993). The Economic Impact on the Forest Sector of Critical Habitat Delineation for Salmon in the Columbia and Snake River Basin. United States Department of Agriculture, Forest Service. Pacific Northwest Research Station.

Heyer, J.; Maitha, J. K.; Senga, W.M. (1976). Agricultural Development in Kenya: an Economic Assessment. Nairobi, Kenya: Oxford University Press.

Kemp, T. (1983). Industrialization in the Non-Western World. Second Edition. New York.: Longman.

Kennedy, Eileen T. (1989). The effects of sugarcane production on food security, health, and nutrition in Kenya : a longitudinal analysis. Washington, D.C.: International Food Policy Research Institute.

Kennedy, Eileen T. (1987). Income and nutritional effects of the commercialization of agriculture in southwestern Kenya. Washington, D.C.: International Food Policy Research Institute.

Korten. D. C. (1990). Getting to the 21st Century: Voluntary Action and the Global Agenda. West Hartford: Kumarian Press, Inc.

Leys, C. (1975). Underdevelopment in Kenya. Los Angeles, CA, USA: University of California Press.

Lisk, Franklyn. (1985). Popular Participation in Planning for Basic Needs. New York: St. Martin's Presss, Inc.

Macphee, A. M.(1968). Kenya. New York: F. A. Praeger.

Maletnlema, Tumsifu N. (1991). Politics and Nutrition in Africa. World Health, JulyAugust 1991, p. 14-15.

Mater. Catherine M. (1990). The Valued-Added Timber Solution. Oregon Business, April 1990, pp. 37-38.

Myrick. B. (1975). Three Aspects of Crisis in Colonial Kenya. Syracuse, NY : Maxwell School of Citizenship and Public Affairs, Syracuse University.

Nelson. Harold. (1984). Kenya, a country study. United States Government.

Ntanda Nsereko, D. D. (1993). The Police, Human Rights and the Constitution: An African Perspective. Human Rights Quarterly: A comparative and International Journal of the Social Sciences, Humanities, and Law, vol. 15, no. 3, August 1993, pp. 465-484.

Ochieng', W. R. (1990). Themes in Kenyan History. Nairobi, Kenya: Heinemann Kenya Limited. 
Raikes, Philip. (1991). Modernizing Hunger. Portsmouth, NH, USA: Heinemann Educational Books Inc.

Rostow, W. W. (1990). Theories of Economic Growth from David Hume to the Present. New York: Oxford University Press.

Rotberg, R. I. (1983). Imperialism, Colonialism, and Hunger: East and Central Africa. Lexington, Massachusetts: Lexington Books.

Russett, B. and Starr, H. (1989). World Politics: The Menu For Choice. Third Edition. W. H. Freeman and Cie.

Shapouri, S.; Dommen A. J.; Stacey, R. (1986). Food Aid and the African Food Crisis. Economic Research Service, U.S. Department of Agriculture, Foreign Agricultural Economic Report No. 221.

Shiroya, Okete J. E.(1968). The impact of World War II on Kenya: the Role of Exservicemen in Kenyan Nationalism. Michigan: East Lansing.

So, A. Y. (1990). Social Change and Development : Modernization, Dependency, and World-systems Theories. Newbury Park, Calif. : Sage Publications.

SRI CIS 1991, R 8750-5, 1991. World Population Projections to 2025 by Region and Country.

Strathman, J.; Ruffolo, A. and Bronfman, L.M. (1991). Causes and Consequences of Employment Decline in Oregon's Wood Products Industry: What Do We Really Know? Center of Urban Studies, School of Urban and Public Affairs, Portland State University.

Todaro, M. P. (1983). Third World Economic Development. Fourth Ed. New York.: Longman.

UNHCR. (May 1991). Little Relieffor Africa's Exiles. REFUGEES: UNHCR Report, Vol. 115 pp. 19-24.

UN Statistical Yearbook. (1985/86). Department of International Economic and Social Affairs, Statistical Office. (1988). 1985/1986 Statistical Yearbook. United Nations.

Wambalaba, Wamukota Francis W. (1985). The impact of the multinational corporations on leading issues and policy making in less developed countries : a case study on Kenya. Portland State University.

Wa Thiong'o, Ngugi. (1983). Barrel of a pen : Resistance to Repression in Neo-colonial Kenya. Trenton, N.J. : Africa World Press, of the Africa Research \& Publications Project

Wiseman, J. A. (1991). Political Leaders in Black Africa. England: Edward Elgar Publishing Limited.

World Resources 90-91. Food and Agriculture. Population, Health, Agriculture Production and Land Use. Statistical Research Index (SRI) R9455, 1990-91. 
Watson, Williams. (1958).Tribal Cohesion in a Money Economy: a study of the Mambwe people of Northern Rhodesia. Manchester University Press.

World Debt Tables 1989-90. External Debt of Developing Countries. Washington DC: The World Bank. Volume 1. 


\section{APPENDIX A: TABLES}

TABLE III

\section{GROSS NATIONAL PRODUCT AND OFFICIAL DEVELOPMENT}

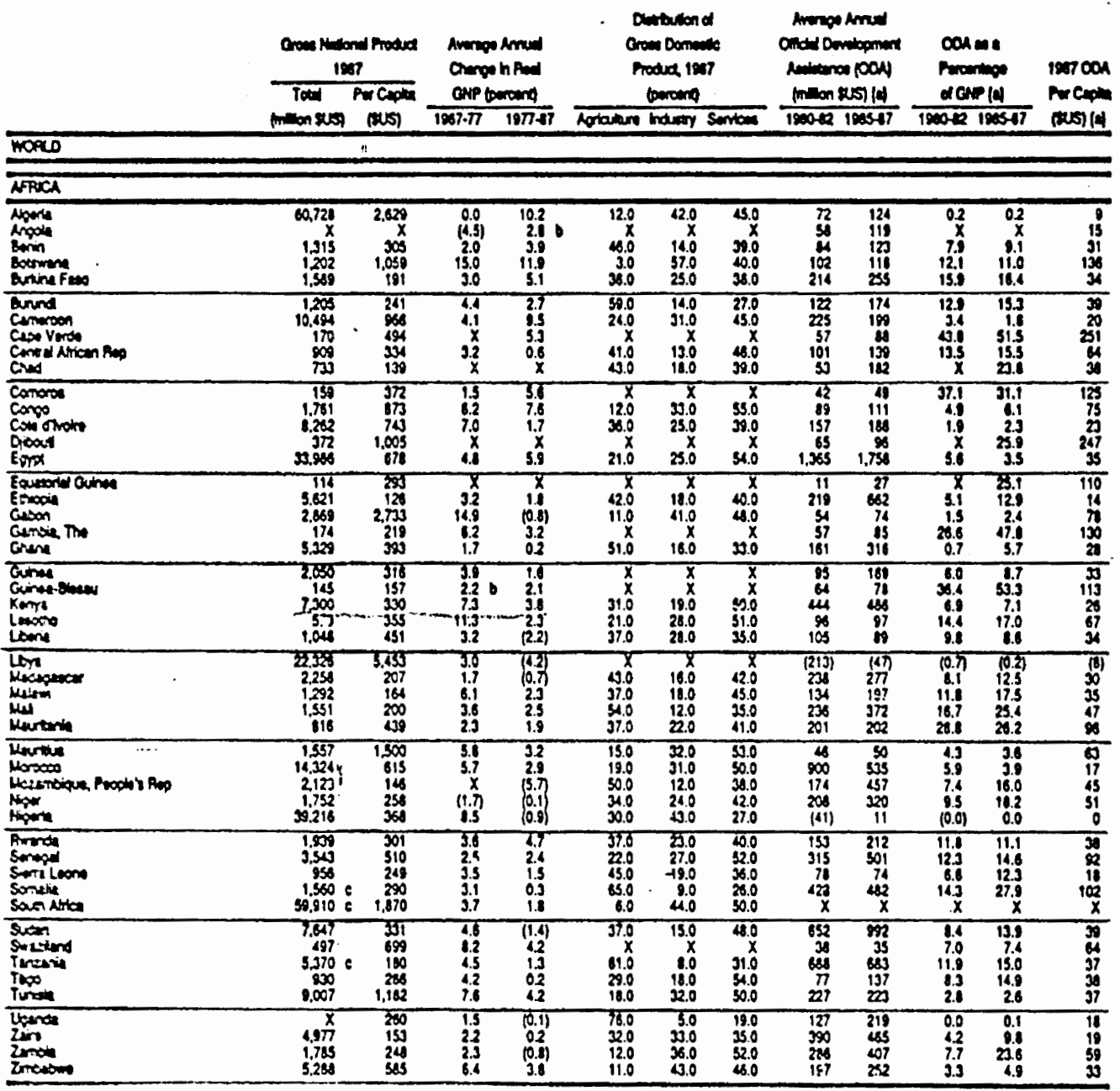

Source: (World Debt Tables, 1989-90). 
TABLE IV

EXTERNAL DEBT INDICATORS, 1977-87

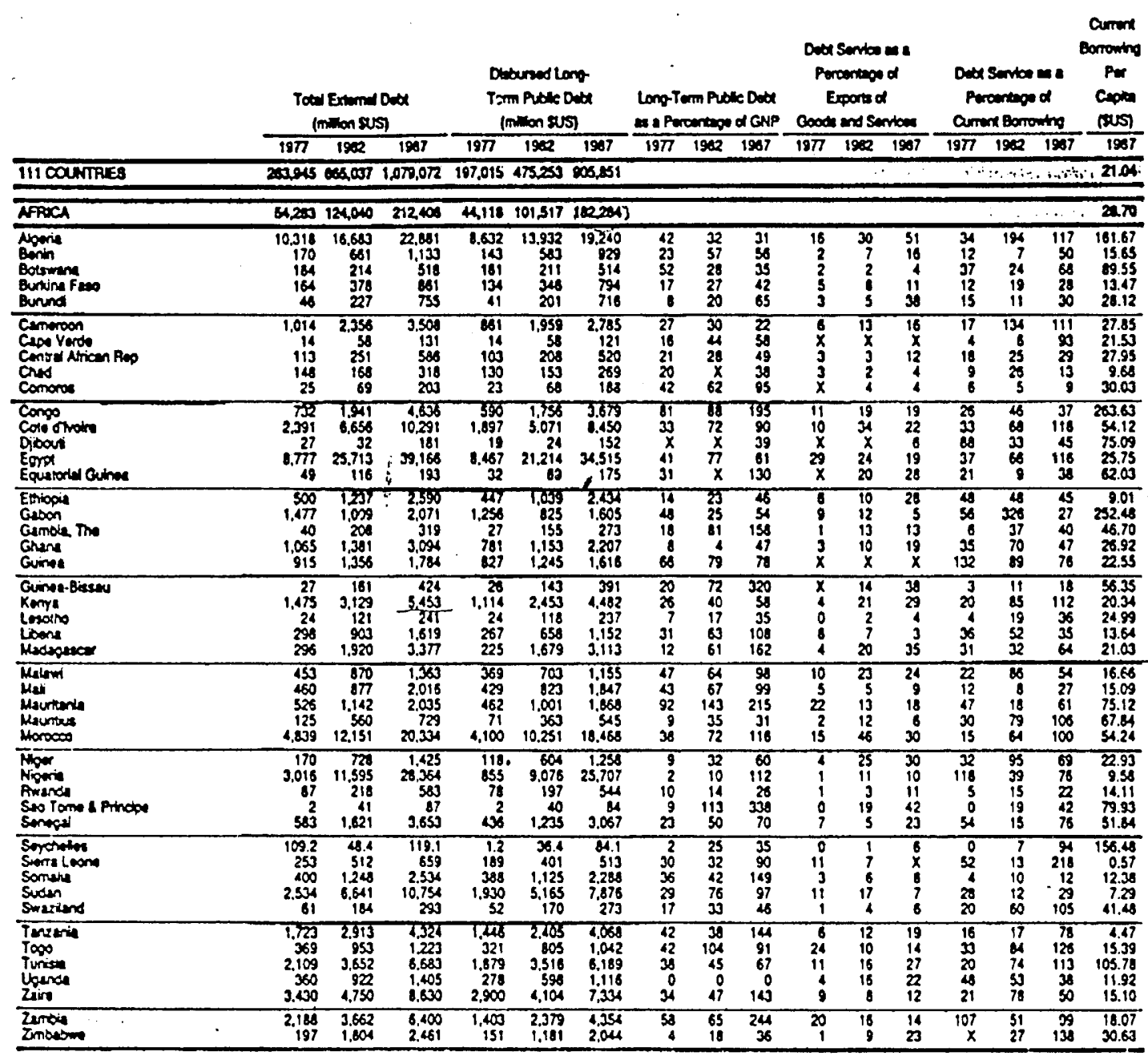

Source: (World Debt Tables, 1989-90). 
TABLE V

KENYA, 1980s: EXTERNAL DEBT IN MILLION US DOLLARS (PULBIC AND PUBLICLY GUARANTEED LONG-TERM)

\begin{tabular}{||r|r|r|r|r|r|r|r|r|r|r||}
\hline 1980s & $\mathbf{1 9 8 0}$ & $\underline{\mathbf{1 9 8 1}}$ & $\mathbf{1 9 8 2}$ & $\mathbf{1 9 8 3}$ & $\mathbf{1 9 8 4}$ & $\underline{\mathbf{1 9 8 5}}$ & $\underline{\mathbf{1 9 8 6}}$ & $\underline{\mathbf{1 9 8 7}}$ & $\mathbf{1 9 8 8}$ & $\mathbf{1 9 8 9}$ \\
\hline Debt & 2197.9 & 2311.0 & 2423.7 & 2419.8 & 2467.3 & 2800.5 & 3537.3 & 4280.9 & 4083.9 & 4001.4 \\
\hline
\end{tabular}

Source: United Nations Statistical Yearbook 1974, 1989.

TABLE VI

KENYA: GROSS DOMESTIC PRODUCT BY KIND

OF ECONOMIC ACTIVITY

\begin{tabular}{|c|c|c|c|c|c|c|c|c|}
\hline \multirow[b]{2}{*}{ Year } & \multirow[b]{2}{*}{$\begin{array}{c}\text { GDP } \\
\text { (million pounds) }\end{array}$} & \multirow[b]{2}{*}{ Agriculture } & \multicolumn{2}{|c|}{ Industrial activity } & \multirow[b]{2}{*}{$\begin{array}{l}\text { Cons- } \\
\text { truction }\end{array}$} & \multirow[b]{2}{*}{$\begin{array}{l}\text { Wholesale } \\
\text { and retail } \\
\text { trade }\end{array}$} & \multirow[b]{2}{*}{ Transport } & \multirow[b]{2}{*}{ Other } \\
\hline & & & Total & $\begin{array}{l}\text { Manufac- } \\
\text { turing }\end{array}$ & & & & \\
\hline 1964 & 355.0 & 38 & 12 & 10 & 4 & 9 & 7 & 23 \\
\hline 1970 & 575.3 & 31 & 13 & 11 & 5 & 10 & 7 & 25 \\
\hline 1972 & 715.5 & 31 & 14 & 12 & 5 & 9 & 7 & 26 \\
\hline 1973 & 805.7 & 30 & 15 & 13 & 5 & 10 & 6 & 25 \\
\hline
\end{tabular}

Source: United Nations Statistical Yearbook 1974. 
TABLE VII

SELF-SUFFICIENCY RATIOS 1

\begin{tabular}{l|c|c|c}
\hline Country & $\mathbf{1 9 6 6 - 6 8}$ & $\mathbf{1 9 8 1 - 8 3}$ \\
\hline & & Ratio & \\
Ethiopia & 0.95 & & 0.90 \\
Kenya & 1.23 & .94 \\
Lesotho & .99 & .47 \\
Mali ${ }^{1}$ & 1.17 & .96 \\
Mozambique & .93 & .56 \\
& & \\
Niger & 1.03 & .94 \\
Senegal & .98 & .63 \\
Somalia & .81 & .42 \\
Sudan & .81 & 1.00 \\
Zambia & 1.03 & .85 \\
Zimbabwe & 1.20 & 1.29 \\
\hline
\end{tabular}

Source: Shapouri et al. (p.37)

${ }^{1}$ Defined as the ratio of available food production to food availability.

TABLE VIII

PER CAPITA CALORIES AVAILABLE FROM CEREALS

\begin{tabular}{|c|c|c|c|c|c|c|}
\hline \multirow[b]{3}{*}{ Country } & \multirow{3}{*}{$\begin{array}{l}\text { Contribution of } \\
\text { cereals to calorie } \\
\text { consumptio n }\end{array}$} & \multicolumn{5}{|c|}{ Daily calorie availability } \\
\hline & & \multirow[t]{2}{*}{$1966-68$} & \multirow[t]{2}{*}{$1981-83$} & \multicolumn{3}{|c|}{ Percent of minimum calorie requirement } \\
\hline & & & & $1966-68$ & $1981-83$ & 1981 \\
\hline & (1) & (2) & (3) & (4) & $(5)$ & (6) \\
\hline & Percent & \multicolumn{2}{|c|}{.......... Calories ......... } & \multicolumn{3}{|c|}{ Percent ................... } \\
\hline Ethiopia & 68 & 2,346 & 1,819 & 100 & 78 & 76 \\
\hline Kenya & 56 & 2,079 & 2,022 & 89 & 86 & 88 \\
\hline Lesotho & 76 & 1,848 & 2,281 & 79 & 98 & 111 \\
\hline Mali & 72 & 2,012 & 1,568 & 86 & 65 & 72 \\
\hline Mozambique & 36 & 2,403 & 1,592 & 103 & 68 & 70 \\
\hline Niger & 67 & 2,265 & 2,106 & 97 & 99 & 102 \\
\hline Senegal & 65 & 2,158 & 2,293 & 92 & 96 & 101 \\
\hline Somalia & 43 & 1,780 & 2,176 & 73 & 89 & 100 \\
\hline Sudan & 56 & 1,982 & 1,979 & 85 & 85 & 99 \\
\hline Zambia & 65 & 2,246 & 2,230 & 96 & 95 & 93 \\
\hline Zimbabwe & 63 & 2,498 & 2,215 & 107 & 95 & 90 \\
\hline
\end{tabular}

Source: (Shapouri et al. 1986, p. 7). 
TABLE IX

CEREAL FOOD AID TO TROPICAL AFRICA 1970/1-72/3 TO 1985/6 ('000tons)

\begin{tabular}{|c|c|c|c|c|c|c|c|c|c|}
\hline Country/ year & $\begin{array}{c}70 / 1- \\
72 / 3 \\
\end{array}$ & $73 / 74$ & $\begin{array}{c}74 / 5- \\
76 / 7 \\
\end{array}$ & $\begin{array}{r}77 / 8- \\
79 / 80 \\
\end{array}$ & $80 / 81$ & $82 / 83$ & $83 / 84$ & $84 / 85$ & $85 / 86$ \\
\hline Angola & 0 & 0 & 5 & 13 & 25 & 60 & 69 & 72 & 91 \\
\hline Burkina Faso & 38 & 108 & 22 & 46 & 51 & 45 & 57 & 143 & 54 \\
\hline Cape Verde & 0 & 0 & 15 & 38 & 31 & 35 & 63 & 49 & 53 \\
\hline Chad & 3 & 67 & 19 & 29 & 14 & 36 & 69 & 203 & 45 \\
\hline Ethiopia & 10 & 96 & 72 & 117 & 228 & 344 & 172 & 1265 & 675 \\
\hline Ghana & 85 & 36 & 40 & 89 & 94 & 58 & 74 & 110 & 61 \\
\hline Guinea & 28 & 9 & 31 & 30 & 34 & 25 & .43 & 34 & 27 \\
\hline G. Bissau & 0 & 0 & 12 & 19 & 26 & 35 & 19 & 23 & 6 \\
\hline Kenya & 2 & 1 & 6 & 35 & 173 & 165 & 122 & 346 & 193 \\
\hline Lesotho & 20 & 25 & 14 & 30 & 44 & 28 & 50 & 77 & 60 \\
\hline Mali & 41 & 180 & 49 & 26 & 50 & 88 & 111 & 239 & 113 \\
\hline Mauritania & 21 & 95 & 35 & 36 & 106 & 71 & 129 & 236 & 94 \\
\hline Mauritius & 23 & 33 & 17 & 13 & 21 & 13 & 22 & 17 & 15 \\
\hline Mozambique & 0 & 0 & 62 & 136 & 155 & 167 & 297 & 350 & 428 \\
\hline Niger & 21 & 195 & 68 & 17 & 11 & 12 & 13 & 284 & 80 \\
\hline Senegal & 30 & 101 & 25 & 96 & 153 & 91 & 151 & 97 & 69 \\
\hline Somalia & 5 & 16 & 82 & 99 & 330 & 189 & 177 & 262 & 128 \\
\hline Sudan & 32 & 79 & 42 & 138 & 195 & 330 & 450 & 1350 & 548 \\
\hline Tanzania & 8 & 11 & 131 & 82 & 236 & 171 & 136 & 118 & 93 \\
\hline Zaire & 21 & 3 & 12 & 58 & 77 & 110 & 53 & 100 & 103 \\
\hline Zambia & 0 & 0 & 13 & 78 & 85 & 83 & 76 & 117 & 119 \\
\hline Other & 34 & 66 & 41 & 87 & 196 & 316 & 573 & 400 & 294 \\
\hline Total SSA & 425 & 1121 & 812 & 1312 & 2335 & 2472 & 2926 & 5892 & 3349 \\
\hline
\end{tabular}

Source: Modernizing Hunger (Raikes, 1991, p.188). 
PORTION OF RECIPIENTS FOOD AID (TONNAGE)

FROM THE UNITED STATES,1966-1983

\begin{tabular}{|c|c|c|c|c|c|c|c|c|c|c|}
\hline Year & $\begin{array}{l}\text { Ethio- } \\
\text { pia }\end{array}$ & Kenya & $\begin{array}{l}\text { Leso- } \\
\text { tho }\end{array}$ & Mali & $\begin{array}{l}\text { Mozam- } \\
\text { bique }\end{array}$ & Niger & Senegal & Somalia & Sudan & Zambia \\
\hline \multicolumn{11}{|c|}{$\underline{\text { Percent }}$} \\
\hline 1966 & 96.73 & 100.00 & .. & .. & .. & .. & 100.00 & 100.00 & 100.00 & 100.00 \\
\hline 1967 & 46.67 & 100.00 & .. & .. & .. & .. & 100.00 & 100.00 & 100.00 & .. \\
\hline 1968 & 0 & 100.00 & .. & .. & .. & .. & .. & 100.00 & .. & .. \\
\hline 1969 & 0 & .. & 0 & 0 & .. & 0 & 81.31 & 55.56 & 0 & .. \\
\hline 1970 & 97.66 & 100.00 & .. & 0 & .. & 0 & 100.00 & 8,85 & 0 & 100.00 \\
\hline 1971 & 100.00 & 100.00 & .. & 0 & .. & .. & 100.00 & 10.11 & 0 & 100.00 \\
\hline 1972 & 100.00 & 100.00 & 100.00 & 4.60 & .. & 4.11 & 20.29 & 0 & 0 & 100.00 \\
\hline 1973 & 23.08 & 85.71 & 89.80 & 37.01 & .. & 70.14 & 33.89 & 0 & 62.16 & 5.66 \\
\hline 1974 & 54.89 & .. & 100.00 & 55.51 & \multicolumn{2}{|c|}{ TABLE X 60.84} & 31.72 & 0 & 85.55 & .. \\
\hline 1975 & 20.38 & 0 & 100.00 & 6.07 & 0 & 7.42 & 6.80 & 17.52 & 30.80 & 13.79 \\
\hline 1976 & 16.67 & 12.64 & 94.64 & 1.19 & 0 & 25.30 & 29.92 & 11.99 & 2.78 & .99 \\
\hline 1977 & 30.53 & 6.92 & 100.00 & 100.0 & 17.13 & 8.33 & 10.73 & 3.15 & 86.07 & 33.73 \\
\hline & & & & 0 & & & & & & \\
\hline 1978 & 32.97 & 14.75 & 86.29 & 52.94 & 33.57 & 46.78 & 47.88 & 52.17 & 84.77 & 0 \\
\hline 1979 & 42.80 & 4.14 & 100.00 & 25.67 & 51.54 & 1.06 & 32.58 & 68.34 & 79.04 & 69.18 \\
\hline 1980 & 33.19 & 82.00 & 61.52 & 19.59 & 59.72 & 80.00 & 54.45 & 67.78 & 89.14 & 75.09 \\
\hline 1981 & 11.79 & 67.19 & 97.75 & 6.86 & 6.77 & 27.54 & 42.02 & 65.76 & 81.29 & 70.79 \\
\hline 1982 & 1.19 & 47.46 & 56.86 & 6.86 & 6.77 & 28.55 & 28.37 & 38.10 & 55.18 & 44.43 \\
\hline 1983 & 2.31 & 60.13 & 55.81 & 20.15 & 14.62 & 100.0 & 58.78 & 85.49 & 44.91 & 45.82 \\
\hline $\begin{array}{l}1981- \\
1983 \\
\text { avera- } \\
\text { ge }\end{array}$ & 5.10 & 58.26 & 70.14 & 9.00 & 10.17 & 52.03 & 43.06 & 63.12 & 60.46 & 53.68 \\
\hline
\end{tabular}

Source: (Shapouri et al. 1986, p. 50).

..$=$ no food aid received from any country 
TABLE XI

PER CAPITA FOOD AID

FROM THE UNITED STATES, 1966-1983

\begin{tabular}{|c|c|c|c|c|c|c|c|c|c|c|c|}
\hline Year & $\begin{array}{l}\text { Ethio- } \\
\text { pia }\end{array}$ & Kenya & $\begin{array}{l}\text { Leso- } \\
\text { tho } \\
\end{array}$ & Mali & $\begin{array}{l}\text { Mozm } \\
\text {-bique } \\
\end{array}$ & Niger & $\begin{array}{l}\text { Sene- } \\
\text { gal }\end{array}$ & $\begin{array}{l}\text { Soma- } \\
\text { lia } \\
\end{array}$ & Sudan & $\begin{array}{l}\text { Zam- } \\
\text { bia }\end{array}$ & $\begin{array}{l}\text { Zimba } \\
\text {-bwe }\end{array}$ \\
\hline \multicolumn{12}{|c|}{ Kilograms } \\
\hline 1966 & 1.19 & 20.16 & 0 & 0 & 0 & 0 & 4.76 & 0.76 & 3.17 & 0.16 & 0 \\
\hline 1967 & .13 & .12 & 0 & 0 & 0 & 0 & & & & & 0 \\
\hline 1968 & .06 & .26 & 0 & 0 & 0 & 0 & 13.51 & .27 & 1.31 & 0 & 0 \\
\hline 1969 & .36 & 0 & 2 & 0.61 & 0 & 4.92 & 7.46 & .22 & 1.85 & 0 & 0 \\
\hline 1970 & .50 & .20 & $\underline{0}$ & 6.00 & 0 & 3.85 & 4.12 & 3.21 & .73 & .24 & $\underline{0}$ \\
\hline 1971 & .13 & .25 & 0 & 3.82 & 0 & 0 & 3.65 & 4.79 & .64 & .05 & 0 \\
\hline 1972 & .37 & .14 & 13.18 & 8.23 & 0 & 11.88 & 4.70 & 4.29 & .83 & .11 & 0 \\
\hline 1973 & .24 & .11 & 17.82 & 16.77 & 0 & 11.88 & 11.74 & 4.29 & 2.50 & 1.18 & 0 \\
\hline 1974 & 3.55 & 0 & 4.75 & 31.67 & 0 & 43.35 & 19.17 & 3.33 & 2.28 & 0 & 0 \\
\hline 1975 & 1.32 & .37 & 6.25 & 8.69 & .21 & 8.69 & 6.13 & 13.92 & 1.85 & 1.21 & $\underline{0}$ \\
\hline 1976 & 1.04 & .62 & 9.33 & $1.45^{\circ}$ & 6.13 & 18.30 & 4.88 & 15.37 & .90 & 4.06 & 0 \\
\hline 1977 & 1.78 & .89 & 7.75 & .03 & 11.41 & .77 & 14.41 & 13.82 & 4.16 & 8.20 & 0 \\
\hline 1978 & 2.07 & .40 & 9.54 & 7.25 & 7.53 & 7.44 & 24.06 & 14.79 & 5.99 & 2.26 & 0 \\
\hline 1979 & 2.47 & 1.07 & 12.08 & 2.97 & 10.25 & 3.76 & 8.19 & 19.07 & 9.16 & 15.22 & 0 \\
\hline 1980 & 2.88 & 7.41 & 35.38 & 1.49 & 13.35 & .98 & 15.93 & 46.29 & 10.17 & 29.11 & 1.30 \\
\hline 1981 & 3.47 & 11.87 & 19.07 & 5.58 & 12.29 & 2.60 & 18.04 & 42.33 & 12.89 & 17.83 & 1.05 \\
\hline 1982 & 5.60 & 8.39 & 10.93 & 6.85 & 15.08 & 10.19 & 11.00 & 29.08 & 14.23 & 10.02 & .66 \\
\hline 1983 & 3.09 & 7.43 & 15.36 & 7.59 & 28.51 & .29 & 14.15 & 12.43 & 20.17 & 15.06 & 1.23 \\
\hline \multicolumn{12}{|l|}{ Avg. } \\
\hline 1966- & 1.68 & 3.32 & 9.08 & 6.06 & 5.82 & 6.60 & 10.66 & 12.68 & 5.16 & 5.82 & .24 \\
\hline \multicolumn{12}{|l|}{83} \\
\hline 1981- & 4.05 & 9.23 & 15.12 & 6.67 & 18.63 & 4.36 & 14.40 & 27.95 & 15.77 & 14.30 & .98 \\
\hline 83 & & & & & & & & & & & \\
\hline
\end{tabular}

Source: (Shapouri et al. 1986, p. 52). Most of the food aid came from P.L. 480 title I and title II 
TABLE XII

FOOD IMPORTS AND FOOD AID DEPENDENCY

\begin{tabular}{|c|c|c|c|c|c|c|c|c|c|}
\hline \multirow[b]{2}{*}{ Country } & \multicolumn{3}{|c|}{ Commercial food imports } & \multicolumn{3}{|c|}{ Food aid } & \multicolumn{3}{|c|}{ Food aid dependency } \\
\hline & 1966-68 & 1971-73 & $1981-83$ & 1966-68 & 1971-73 & $1981-83$ & 1966-68 & 1971-73 & $1981-83$ \\
\hline & (1) & (2) & (3) & (4) & (5) & (6) & (7) & (8) & (9) \\
\hline & ............ & 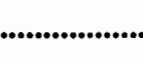 & ..................... & 000 tons. & (........................ & .......... & ............. & .....Percen & t.......... \\
\hline Ethiopia & 33.0 & 31.3 & 79.9 & 5.7 & 6.6 & 212.2 & 0.1 & 0.2 & 3.7 \\
\hline Kenya & 27.0 & 53.0 & 212.0 & 67.2 & 2.0 & 177.3 & 4.8 & .1 & 7.4 \\
\hline Lesotho & 29.0 & 50.7 & 178.3 & 0 & 11.4 & 29.0 & 0 & 5.9 & 10.7 \\
\hline Mali & 14.0 & 47.7 & 95.0 & 0 & 50.4 & 54.5 & 0 & 5.9 & 6.1 \\
\hline $\begin{array}{l}\text { Mozam- } \\
\text { bique }\end{array}$ & 66.0 & 115.7 & 196.7 & 0 & 0 & 142.3 & 0 & 0 & 17.5 \\
\hline Niger & 8.3 & 13.3 & 79.3 & 0 & 19.1 & 30.3 & 0 & 3.0 & 3.0 \\
\hline Senegal & 234.7 & 270.7 & 427.3 & 31.6 & 30.1 & 93.2 & 5.1 & 4.6 & 9.1 \\
\hline Somalia & 35.0 & 74.3 & 176.3 & 1.0 & 15.4 & 168.8 & .4 & 5.1 & 30.9 \\
\hline Sudan & 161.0 & 203.0 & 126.3 & 18.8 & 19.3 & 305.8 & 1.1 & 1.0 & 11.7 \\
\hline Zambia & 63.0 & 205.0 & 172.7 & .2 & 2.0 & 90.6 & 0 & .2 & 8.1 \\
\hline $\begin{array}{l}\text { Zimba- } \\
\text { bwe }\end{array}$ & 85.0 & 49.7 & 36.7 & 0 & 0 & 7.8 & 0 & 0 & .6 \\
\hline Total & 736.0 & $1,114.4$ & $1,780.5$ & 124.5 & 156.3 & $1,311.8$ & 1.0 & 1.2 & 7.4 \\
\hline
\end{tabular}

Source: (Shapouri et al. 1986, p. 54). 
TABLE XIII

FOOD AID REPRESENTED AS A PERCENTAGE OF DOMESTIC FOOD PRODUCTION

\begin{tabular}{|c|c|c|c|c|c|c|c|c|c|c|c|}
\hline Year & $\begin{array}{l}\text { Ethio- } \\
\text { pia }\end{array}$ & Kenya & $\begin{array}{l}\text { Leso - } \\
\text { tho }\end{array}$ & Mali & $\begin{array}{l}\text { Mozm } \\
\text { bique }\end{array}$ & Niger & $\begin{array}{l}\text { Seneg } \\
\text { al } \\
\end{array}$ & $\begin{array}{l}\text { Soma- } \\
\text { lia } \\
\end{array}$ & Sudan & $\begin{array}{l}\text { Zam- } \\
\text { bia }\end{array}$ & $\begin{array}{l}\text { Zimba } \\
\text {-bwe }\end{array}$ \\
\hline \multicolumn{12}{|c|}{ Percent } \\
\hline 1966 & 0.60 & 11.09 & 0 & 0 & 0 & 0 & 2.51 & 1.10 & 3.17 & 0.06 & 0 \\
\hline 1967 & 0.06 & 0.06 & 0 & 0 & 0 & 0 & 8.93 & 0.32 & 1.38 & 0 & 0 \\
\hline 1968 & 0.03 & 0.12 & 0 & 0 & 0 & 0 & 2.81 & 0 & 0 & 0 & 0 \\
\hline 1969 & 0.17 & 0.00 & 0.98 & 0.31 & 0 & 2.83 & 5.74 & 0.27 & 1.94 & 0 & 0 \\
\hline 1970 & 0.25 & 0.11 & 0 & 2.71 & 0 & 1.60 & 2.06 & 3.93 & 0.49 & 0.13 & 0 \\
\hline 1971 & 0.07 & 0.14 & 0 & 1.93 & 0 & 0 & 2.96 & 7.06 & 0.41 & 0.02 & 0 \\
\hline 1972 & 0.22 & 0.09 & 10.16 & 4.50 & 0 & 0.94 & 2.84 & 6.70 & 0.58 & 0.05 & 0 \\
\hline 1973 & 0.15 & 0.06 & 11.81 & 11.31 & 0 & 6.73 & 14.21 & 4.70 & 2.01 & 0.57 & 0 \\
\hline 1974 & 2.34 & 0.00 & 2.16 & 20.00 & 0 & 37.13 & 14.79 & 3.77 & 1.50 & 0 & 0 \\
\hline 1975 & 0.69 & 0.23 & 4.93 & 4.15 & 0.33 & 5.26 & 3.08 & 17.70 & 1.17 & 0.53 & 0 \\
\hline 1976 & 0.70 & 0.35 & 9.41 & 0.77 & 11.60 & 17.08 & $3: 10$ & 23.74 & 0.52 & 1.66 & 0 \\
\hline 1977 & 1.30 & 0.47 & 3.73 & 0.02 & 18.31 & 0.40 & 10.17 & 23.74 & 2.48 & 3.72 & 0 \\
\hline 1978 & 1.58 & 0.22 & 4.44 & 4.21 & 12.17 & 3.38 & 23.12 & 23.61 & 3.55 & 1.13 & 0 \\
\hline 1979 & 1.23 & 0.69 & 6.23 & 1.43 & 18.50 & 1.87 & 4.41 & 33.52 & 5.03 & 10.49 & 0 \\
\hline 1980 & 1.60 & 6.12 & 23.12 & 0.83 & 28.51 & 0.45 & 13.23 & 85.13 & 8.14 & 17.99 & 0.47 \\
\hline 1981 & 2.17 & 6.73 & 11.61 & 4.12 & 24.38 & 1.20 & 15.74 & 85.00 & 8.56 & 7.76 & 0.23 \\
\hline 1982 & 3.77 & 5.45 & 8.84 & 4.33 & 32.51 & 5.00 & 6.95 & 52.30 & 6.94 & 5.49 & 0.23 \\
\hline 1983 & 2.07 & 4.76 & 14.33 & 4.85 & 96.51 & 1.99 & 11.03 & 22.56 & 16.19 & 8.24 & 0.78 \\
\hline \multicolumn{12}{|l|}{ Avg. } \\
\hline $\begin{array}{l}1966- \\
83\end{array}$ & 1.07 & 2.15 & 6.21 & 3.64 & 13.49 & 4.77 & 8.21 & 21.95 & 3.56 & 3.21 & 0.10 \\
\hline $\begin{array}{l}1981- \\
83\end{array}$ & 2.67 & 6.32 & 11.60 & 4.43 & 51.14 & 2.73 & 11.24 & 53.29 & 10.56 & 7.16 & 0.42 \\
\hline
\end{tabular}

Snurce: (Shapouri et al. 1986, p. 56). 
TABLE XIV

EXPENDITURES BY ACTIVITY GROUP, COHORT SAMPLE, 1985-1987

\begin{tabular}{lcccc}
\hline Activity Group & $\begin{array}{c}\text { Total } \\
\text { Expenditures }\end{array}$ & $\begin{array}{c}\text { Nonfood } \\
\text { Expenditures }\end{array}$ & Food Expenditures & $\begin{array}{c}\text { Food Budget } \\
\text { Share }\end{array}$ \\
\hline & & Ksh/capita/week $)$ & \\
New entrants & 62.61 & 11.48 & 51.13 & 82 \\
Sugar farmers & 52.77 & 12.06 & 40.71 & 77 \\
Nonsugar farmers & 49.14 & 9.59 & 39.55 & 80 \\
Merchants & 77.21 & 37.50 & 39.71 & 51 \\
Landless & 51.99 & 12.38 & 39.61 & 76 \\
Sample mean & 52.71 & 11.74 & 40.97 & 78 \\
\hline
\end{tabular}

Source: (Kennedy 1989, p. 35).

TABLE XV

KENYA: BALANCE OF PAYMENTS 1967-1973

\begin{tabular}{|l|r|r|r|r|r|r|r|}
\hline \multicolumn{1}{|c|}{ Source } & \multicolumn{7}{c|}{ Year } \\
\hline & $\mathbf{1 9 6 7}$ & $\mathbf{1 9 6 8}$ & $\mathbf{1 9 6 9}$ & $\mathbf{1 9 7 0}$ & $\mathbf{1 9 7 1}$ & $\mathbf{1 9 7 2}$ & $\mathbf{1 9 7 3}$ \\
\hline Merchandise: Exp. f.o.b & 221.9 & 235.3 & 253.0 & 285.5 & 293.6 & 310.8 & 384.1 \\
\hline Merchandise: Imp. f.o.b & -291.4 & -302.0 & -303.3 & -381.6 & -491.2 & -429.4 & -460.1 \\
\hline Exports of services & 151.3 & 174.2 & 202.4 & 224.5 & 238.6 & 229.6 & 200.9 \\
\hline Imports of services & -144.9 & -172.7 & -182.9 & -203.0 & -211.7 & -201.3 & -208.1 \\
\hline Private unrequited transfers net & -1.8 & -0.1 & 2.6 & 1.1 & -0.1 & 0.6 & -2.3 \\
\hline Gov. unrequited transf. net & 4.7 & 25.1 & 20.1 & 24.5 & 58.4 & 24.6 & 22.6 \\
\hline Direct investment & 13.8 & 11.9 & 19.2 & 20.9 & 28.4 & 24.9 & 19.1 \\
\hline Other long-term capital, n.i.e & 32.9 & 31.5 & 34.3 & 58.1 & 19.6 & 69.3 & 55.6 \\
\hline Shor-term capital, n.i.e & 14.2 & -8.0 & 2.4 & 7.7 & 3.7 & -0.2 & 8.6 \\
\hline Errors and omissions & 11.2 & 25.2 & 15.6 & 7.6 & -9.8 & -1.8 & 4.8 \\
\hline Allocation of SDR's & - & - & - & 5.4 & 5.1 & 5.1 & - \\
\hline Monetization of gold & - & - & - & - & - & - & - \\
\hline Reserves and Related items & -11.9 & -20.4 & -63.4 & -50.7 & 65.4 & -32.2 & -25.2 \\
\hline
\end{tabular}

Source: United Nations Statistical Yearbook 1974. 
TABLE XVI

KENYA: BALANCE OF PAYMENTS 1983-1989

\begin{tabular}{|l|r|r|r|r|r|r|r|}
\hline \multicolumn{1}{|c|}{ Source } & \multicolumn{7}{|c|}{ Year } \\
\hline & $\mathbf{1 9 8 3}$ & $\mathbf{1 9 8 4}$ & $\mathbf{1 9 8 5}$ & $\mathbf{1 9 8 6}$ & $\mathbf{1 9 8 7}$ & $\mathbf{1 9 8 8}$ & $\mathbf{1 9 8 9}$ \\
\hline Merchandise: Exp. fob & 926.6 & 1034.5 & 943.2 & 1170.2 & 908.7 & 1017.5 & 926.1 \\
\hline Merchandise: Imp. fob & -1197.9 & -1348.2 & -1269.8 & -1454.6 & -1622.6 & -1802.2 & -1963.4 \\
\hline Serv. \& Income: Credit & 98.3 & 628.6 & 663.4 & 732.0 & 829.9 & 862.3 & 1008.5 \\
\hline Serv. \& Income: Debit & -554.7 & -617.8 & -641.4 & -693.0 & -824.6 & -877.8 & -941.2 \\
\hline Private Unrequited Transfers & 63.4 & 60.1 & 81.5 & 58.2 & 72.0 & 89.0 & 101.5 \\
\hline Offic. Unrequited Trans., nie & 116.5 & 116.6 & 110.2 & 149.0 & 141.9 & 256.4 & 280.9 \\
\hline Direct Investments, nie & 9.2 & 3.9 & 12.7 & 27.8 & 45.0 & -19.4 & 68.8 \\
\hline Portfolio Investment, nie & 0.0 & 0.0 & 0.0 & 0.0 & 0.0 & 0.0 & 0.0 \\
\hline Other Capital, nie & 121.5 & 175.2 & 8.6 & 104.8 & 316.8 & 380.9 & 573.0 \\
\hline Net Errors and Related Items & 15.0 & 8.6 & 39.6 & 43.2 & 107.9 & 49.9 & 67.6 \\
\hline Reserves and Related Items & -97.9 & -61.6 & 52.1 & -137.7 & 25.1 & 43.4 & -122.0 \\
\hline Tot. Change in Res. Assets & -171.9 & 3.3 & 8.5 & -18.0 & 158.1 & -8.6 & -20.9 \\
\hline
\end{tabular}

Source: United Nations Statistical Yearbook 1989.

TABLE XVII

KENYA'S DEBT POSITION IN 1987

Total debt $(\$ b n)$ :

Public and public guaranteed long-term debt, by source of creditor $(\$ b n)$ :

- multilateral creditors:

- Bilateral creditors:

- Private creditors:

$\$ 0.78$

Debt/export ratio:

342.0

Source: African Debt: The seqarch for Solutions, Briefing Paper, UN Africa Recovery Programme, No.1 June 1989. 
TABLE XVIII

\section{A STATISTICAL GUIDE TO A CONTINENT IN CRISIS (KENYA: FINANCES)}

\begin{tabular}{|c|c|c|c|c|c|c|c|c|c|c|c|}
\hline \multicolumn{3}{|c|}{$\begin{array}{c}\text { Export fob } \\
(\$ \mathrm{mn})\end{array}$} & \multicolumn{3}{|c|}{$\begin{array}{c}\text { Imports fob } \\
(\$ \mathrm{mn}) \\
\end{array}$} & \multicolumn{3}{|c|}{$\begin{array}{c}\text { Total external debt } \\
(\$ \text { bn }) \\
\end{array}$} & \multicolumn{3}{|c|}{$\begin{array}{c}\text { Debt/exports } \\
\text { ratio }(\%) \\
\end{array}$} \\
\hline 1985 & 1986 & 1987 & 1985 & 1986 & 1987 & 1985 & 1986 & 1987 & 1985 & 1986 & 1987 \\
\hline $1,695.0$ & $1,907.0$ & $1,740.0$ & $1,883.0$ & $2,158.0$ & $2,451.0$ & 4.39 & 4.93 & 5.95 & 275.2 & 258.8 & 342.0 \\
\hline
\end{tabular}

Source: (Africa Recovery, October 1989; extract from table in p.26-27).

TABLE XIX

\section{DEBT SERVICE RATIOS}

\begin{tabular}{|c|c|c|c|c|}
\hline \multirow{3}{*}{ Country } & \multicolumn{4}{|c|}{ Terms of Trade } \\
\hline & \multicolumn{2}{|c|}{$\begin{array}{l}\text { Gross national } \\
\text { product }\end{array}$} & \multicolumn{2}{|c|}{$\begin{array}{l}\text { Exports of goods } \\
\text { and services }\end{array}$} \\
\hline & 1970 & 1983 & 1970 & 1983 \\
\hline & \multicolumn{4}{|c|}{ Percent } \\
\hline Ethiopia & 1.2 & 1.4 & 11.4 & 11.5 \\
\hline Kenya & 1.8 & 5.5 & 5.4 & 20.6 \\
\hline Lesotho & .4 & 1.9 & na & 2.5 \\
\hline Mali & .2 & 1.3 & 1.3 & 6.1 \\
\hline Mozambique & na & na & na & na \\
\hline Niger & .6 & 5.6 & 3.8 & na \\
\hline Senegal & .8 & 1.9 & 2.8 & na \\
\hline Somalia & .3 & 1.2 & 2.1 & 13.1 \\
\hline Sudan & 1.7 & 1.2 & 10.7 & 11.2 \\
\hline Zambia & 3.5 & 4.0 & 5.9 & 12.6 \\
\hline Zimbabwe & 6 & 8.1 & na & 31.6 \\
\hline
\end{tabular}

Source: (Shapouri et al. 1986, p. 43).

na $=$ not available

Cereal stock policies: The government between 1981 and 1983 had stock policies and practices the objective of which were to (1) maintain supplies to domestic markets (2) to meet emergencies (3) to stabilize prices (4) to meet public distributiton programs (5) for strategic considerations. The stocks between 1981-1983 amounted for 494,000 tons representing 17.5 per cent of the all availability. 
TABLE XX

COMMERCIAL FOOD IMPORTS AND TOTAL MERCHANDISE IMPORTS, 1966-83

\begin{tabular}{l|c|c|c|c}
\hline \multirow{2}{*}{ Country } & \multicolumn{2}{|c|}{$\begin{array}{c}\text { Annual growth rate of value of ... } \\
\text { Value of commercial food iports as a } \\
\text { percent of total imports }\end{array}$} \\
\cline { 2 - 5 } & $\begin{array}{c}\text { Merchandise } \\
\text { imports }\end{array}$ & $\begin{array}{c}\text { Commercial food } \\
\text { imports }\end{array}$ & $\mathbf{1 9 8 0 - 8 2}$ & $\begin{array}{c}\text { Historical high } \\
\text { point, 1966-82 }\end{array}$ \\
\hline Ethiopia & & & $\underline{\text { Percent }}$ & \\
Kenya & 11.0 & 15.28 & 10.23 & 13.5 \\
Lesotho & 13.78 & 9.67 & 5.07 & 13.5 \\
Mali 1 & 18.16 & 20.36 & 37.13 & 37.8 \\
Mozambique & 14.76 & 15.33 & 16.50 & 55.3 \\
Niger & na & na & na & na \\
Senegal & 21.25 & 22.80 & 11.57 & 19.9 \\
Somalia & 12.80 & 10.85 & 25.17 & 56.4 \\
Sudan & 16.45 & 19.46 & 43.30 & 25.5 \\
Zambia & 11.82 & 13.19 & 20.40 & 12.4 \\
Zimbabwe & 6.30 & 6.77 & 10.00 & 5.3 \\
\hline
\end{tabular}

Source: (Shapouri et al. 1986, p.38).

na: not available; NA: not applicable

\section{TABLE XXI}

INPUT USES: LAND, TRACTORS, AND FERTILIZER, 1981

\begin{tabular}{l|c|c|c|c}
\hline Country & Arable land & Irrigated land $^{1}$ & $\begin{array}{l}\text { Tractors per } \\
1,000 \text { hectares }\end{array}$ & Fertilizer use \\
\hline & 1,000 hectares & $\underline{\text { Percent }}$ & $\underline{\text { Number }}$ & $\begin{array}{r}\frac{100 \text { grams of }}{\text { nutrient per }} \\
\text { heactare }\end{array}$ \\
Ethiopia & & & & 33 \\
Kenya & 13,220 & 0.5 & 0.314 & 344 \\
Lesotho & 1,830 & 2.7 & 3.607 & 151 \\
Mali & 298 & na & 4.866 & 64 \\
Mozambique & 2,055 & 5.6 & .419 & 12 \\
& 2,850 & 2.4 & 2.043 & 10 \\
Niger & & & & 47 \\
Senegal & 3,450 & 1.1 & 0.056 & 12 \\
Somalia & 5,220 & 3.5 & 1.091 & 60 \\
Sudan & 1,100 & 15.0 & 0.937 & 166 \\
Zambia & 12,390 & 15.0 & 0.903 & 682 \\
Zimbabwe & 5,150 & 0.2 & 7.883 & \\
\hline
\end{tabular}

Source: (Shapouri et al. 1986, p. 21).

${ }^{1}$ Irrigated land as a percent of arable land 


\section{TABLE XXII}

A STATISTICAL GUIDE TO A CONTINENT IN CRISIS (KENYA: AGRICULTURE AND FOOD PRODUCTION)

\begin{tabular}{|c|c|c|c|c|c|c|c|c|c|}
\hline \multirow{2}{*}{$\begin{array}{c}\begin{array}{c}\text { GNP per capita } \\
\text { ( } \$ \text { per year) }\end{array} \\
\mathbf{1 9 8 6}\end{array}$} & \multicolumn{3}{|c|}{$\begin{array}{l}\text { Agricultural production } \\
(1979-81=100)\end{array}$} & \multicolumn{3}{|c|}{$\begin{array}{l}\text { Food production } \\
(1979-81=100)\end{array}$} & \multicolumn{3}{|c|}{$\begin{array}{c}\text { Food production per } \\
\text { capita } \\
(1979-81=100) \\
\end{array}$} \\
\hline & 1985 & 1986 & 1987 & 1985 & 1986 & 1987 & 1985 & $\overline{1986}$ & 1987 \\
\hline 300 & 117.5 & 128.0 & 124.3 & 114.0 & 124.4 & 118.2 & 92.7 & 97.0 & 88.3 \\
\hline
\end{tabular}

Source: (Africa Recovery, October 1989; extract from table in p.26-27).

TABLE XXIII

DISTRIBUTION OF AGRICULTURAL INPUTS

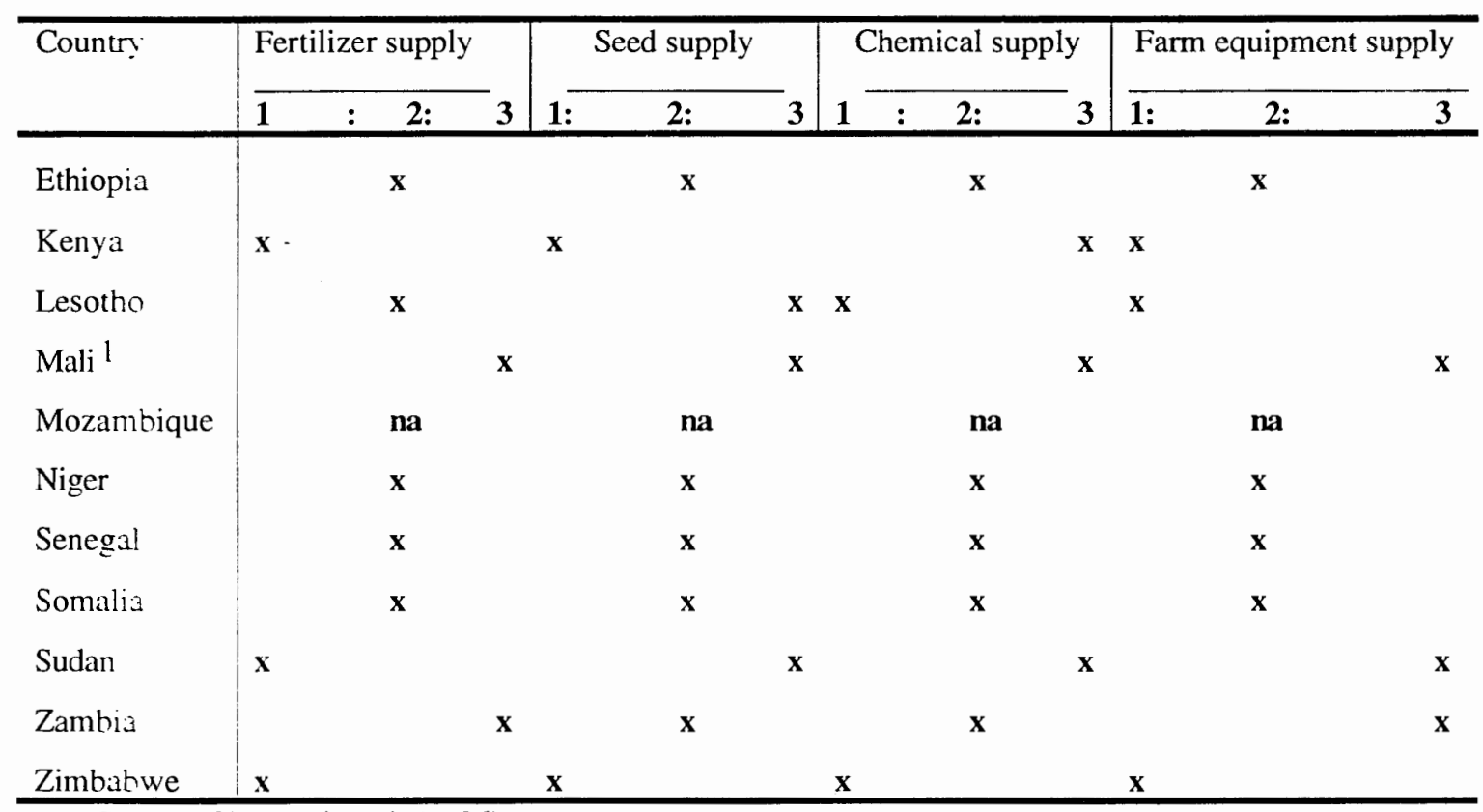

Source: Shapouri et al. (p. 26)

\begin{tabular}{|c|c|c|}
\hline 1 & $=$ & Private \\
\hline 2 & $=$ & Government \\
\hline 3 & $=$ & Mixed \\
\hline na & $=$ & not av \\
\hline
\end{tabular}

'Supplies came from the operations de Developpement Rural (ODR). The most effective of these is the quasi-governmental Compagnie Malienne des Textiles (CMDT) 
TABLE XXX

\section{KENYA: MILITARY EXPENDITURES AS A PERCENTAGE OF GOVERNMENT TOTAL}

\begin{tabular}{|c|c|c|c|c|c|c|c|}
\hline \multicolumn{8}{|c|}{ Functional Classification of Central Government Expenditure on Recurrent Account ${ }^{\mathbf{a}}$} \\
\hline$(\mathrm{K} £ \mathrm{mn})$ & $1981 / 82$ & $1982 / 83$ & $1983 / 84$ & $1984 / 85$ & $1985 / 86^{b}$ & $1986 / 87 b$ & $\frac{\% \text { of }}{\text { total }}$ \\
\hline $\begin{array}{l}\text { General public administration } \\
\text { of which: }\end{array}$ & 130.3 & 111.4 & 132.3 & 159.4 & 164.7 & 199.4 & 12.5 \\
\hline general administration & 66.1 & 64.8 & 62.3 & 84.2 & 74.6 & 91.0 & 5.7 \\
\hline externa & 10.3 & 12.2 & 13.8 & 15.6 & 20.1 & 26.7 & 1.7 \\
\hline public order \& safety & 54.0 & 34.4 & 56.2 & 59.6 & 70.0 & 81.8 & 5.1 \\
\hline $\begin{array}{l}\text { Defence: (total) } \\
\text { (as \% of total gov. exp.) }\end{array}$ & $\begin{array}{r}122.4 \\
14.7 \%\end{array}$ & $\begin{array}{r}130.6 \\
13.5 \%\end{array}$ & $\begin{array}{r}129.5 \\
13 \%\end{array}$ & $\begin{array}{l}100.7 \\
8.5 \%\end{array}$ & $\begin{array}{l}105.2 \\
8.4 \%\end{array}$ & $\begin{array}{l}145.4 \\
9.0 \%\end{array}$ & $\begin{array}{l}9.1 \\
9.1\end{array}$ \\
\hline Education & 180.6 & 192.1 & 210.5 & 245.2 & 310.6 & 373.9 & $23 . \mathrm{i}$ \\
\hline Health & 59.8 & 62.0 & 64.4 & 72.5 & 70.6 & 96.0 & 6.0 \\
\hline $\begin{array}{l}\text { Housing \& community } \\
\text { welfare }\end{array}$ & 2.8 & 3.0 & 3.1 & 3.3 & 4.4 & 2.2 & 0.1 \\
\hline Social welfare & 5.1 & 17.3 & 2 & 23.4 & 27.2 & 33.1 & 2.1 \\
\hline vhich: & 126.9 & 134.8 & 139.2 & 187.0 & 176.2 & 269.4 & 16.8 \\
\hline administration & 11.7 & 10.7 & 11.7 & 9.6 & 16.7 & 18.5 & 1.2 \\
\hline agriculture, forestry & 45.3 & 58.6 & 54.1 & 97.8 & 65.9 & 135.6 & 8.5 \\
\hline $\begin{array}{l}\text { \&fishing } \\
\text { mining, manufacturing \& } \\
\text { construction }\end{array}$ & 14.0 & 15.0 & 17.0 & 25.7 & 34.4 & 34.0 & 2.1 \\
\hline $\begin{array}{l}\text { electricity, gas, steam } \\
\text { \&water }\end{array}$ & 13.7 & 13.1 & 16.4 & 16.0 & 18.7 & 19.1 & 1.2 \\
\hline roads & 19.9 & 16.1 & 19.6 & 9.6 & 7.5 & 11.5 & 0.7 \\
\hline transport & 7.4 & 7.9 & 7.4 & 8.2 & 11.8 & 10.4 & 0.6 \\
\hline other & 15.1 & 13.4 & 13.0 & 20.1 & 16.4 & 40.3 & 2.5 \\
\hline $\begin{array}{l}\text { Other services. incl public } \\
\text { debt }\end{array}$ & $\underline{192.4}$ & $\underline{316.5}$ & 299.5 & $\underline{384.4}$ & $\underline{339.6}$ & $\underline{480.2}$ & $\underline{30.0}$ \\
\hline Total & 830.3 & 967.7 & $996.2^{c}$ & $1,175.9$ & 1. $255.2^{\mathrm{c}}$ & $1,600.1$ & 100.0 \\
\hline
\end{tabular}

a Fiscal year's ending June 30; includes a small element of investment expenditure. b Provisional.

c Columns do not add to total in original source.

Source: Economic Intelligence Unit 1986/87. 


\section{APPENDIX B: FIGURES $\left(^{*}\right)$}

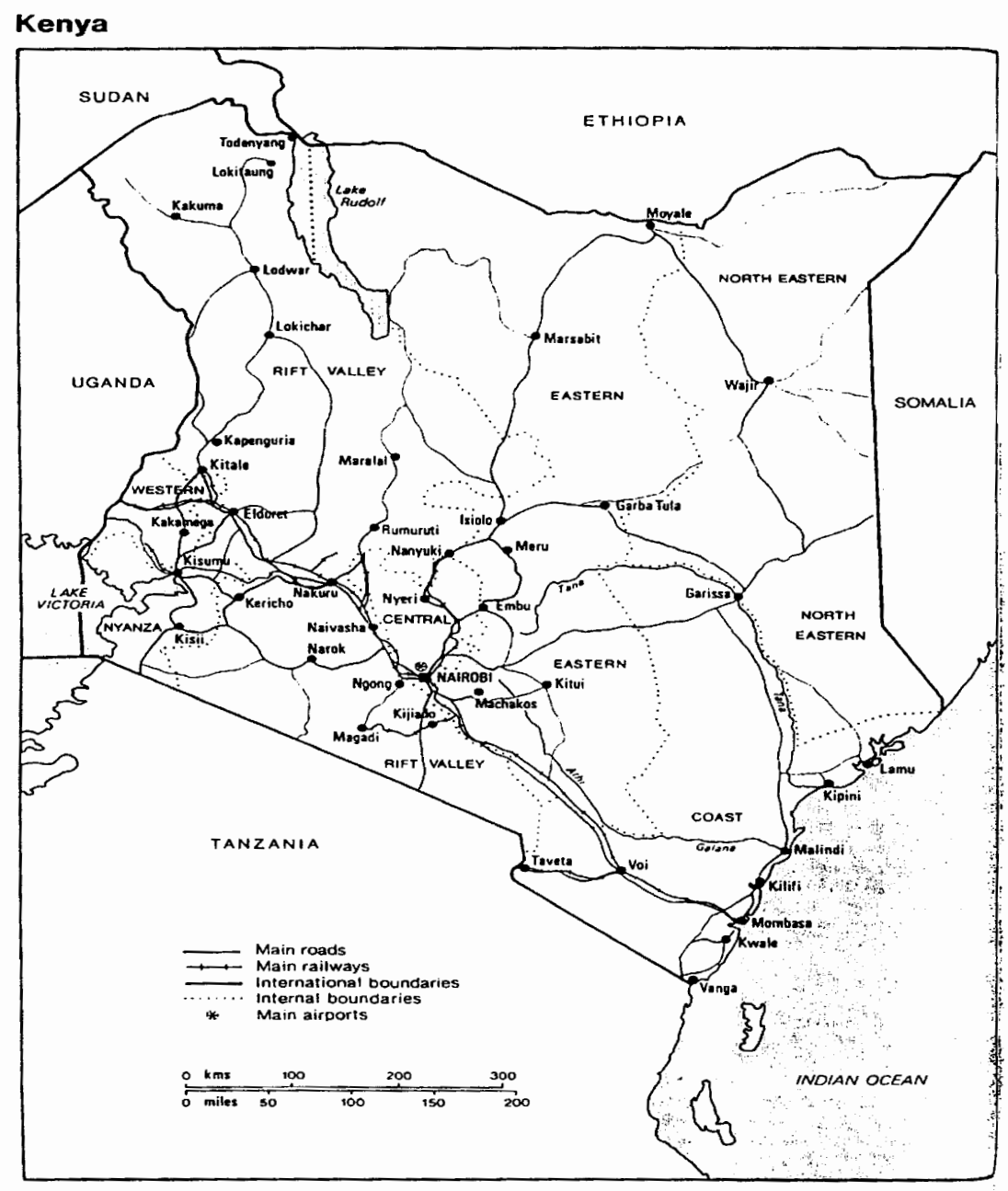

Figure 1.a. Official map of contemporary Kenya.

$\left(^{*}\right)$ Figure 1.a and Figure 1.b are borrowed from (EIU 1991). Figure 2 and 23 are borrowed from (Nelson, 1984). Figures 6-22 are borrowed from (Heyer et al., 1976). Figure 3, 4, and 5 are borrowed from (Hanley, Feb. 22,23, 1992). 


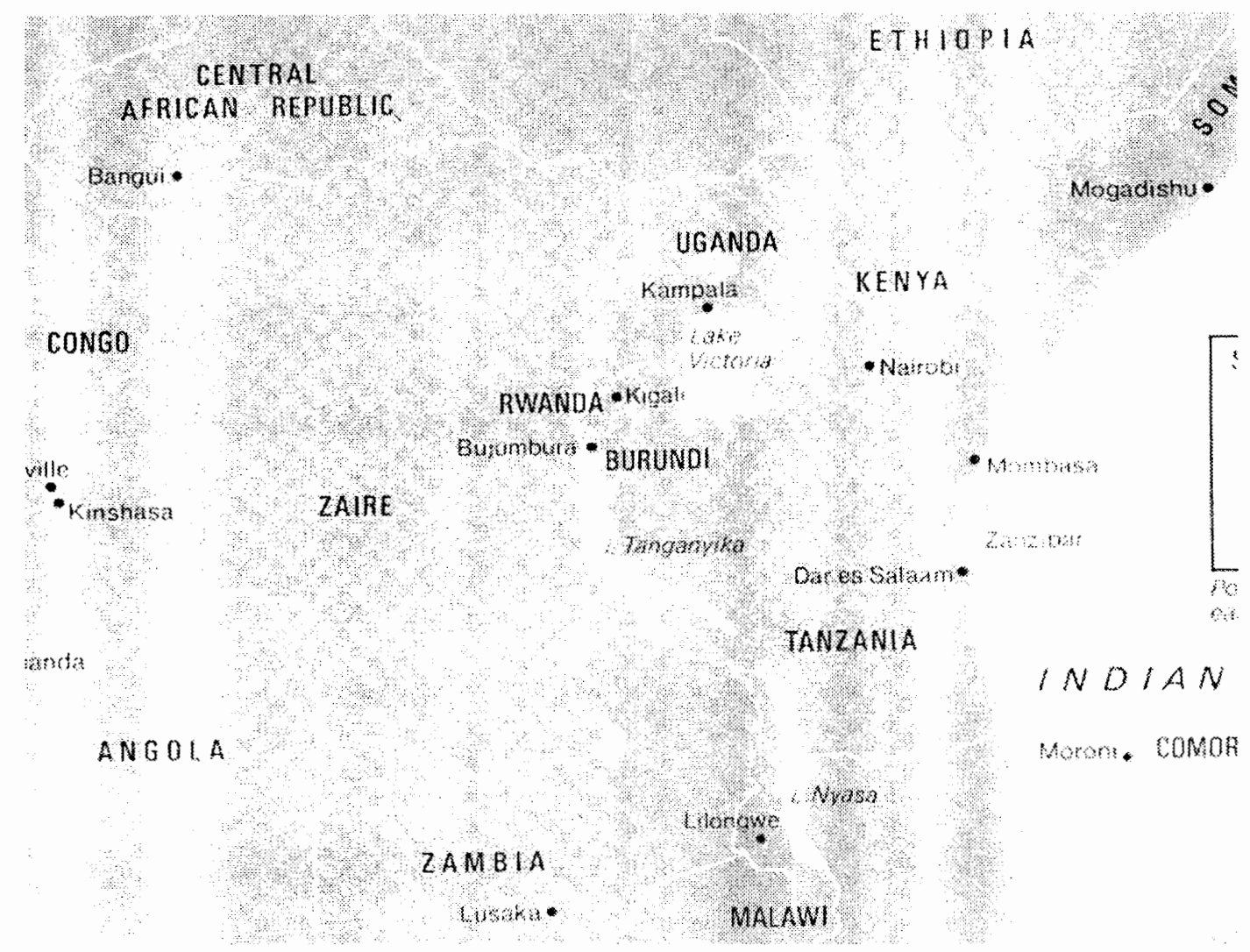

Figure 1.b. Kenya: Geographical Location in the East African Region. 


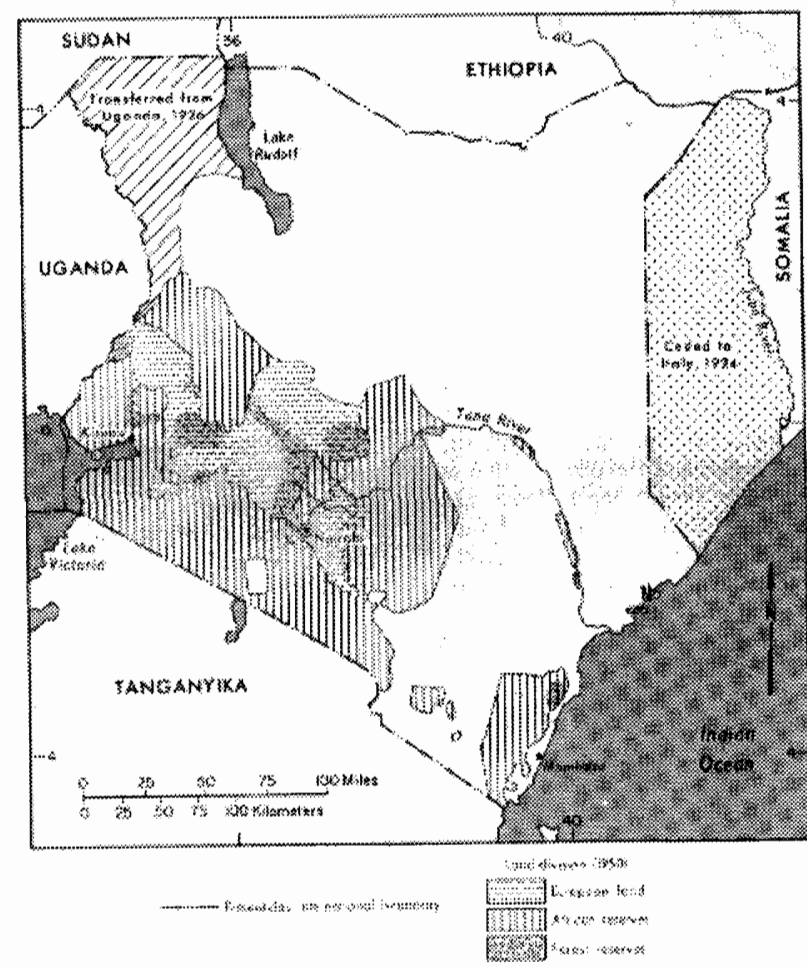

Figure 2. Kenya: Colony and Protectorate 1920-63

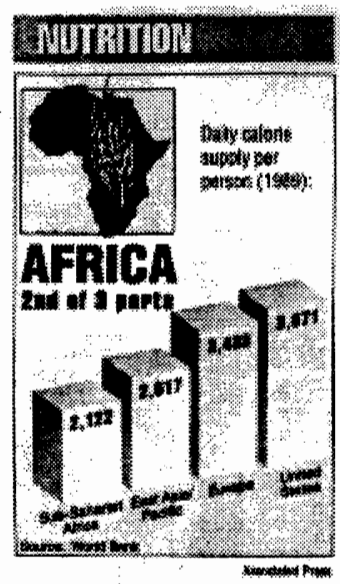

Figure 4. Africa: Nutrition Compared with other Continents, 1989.

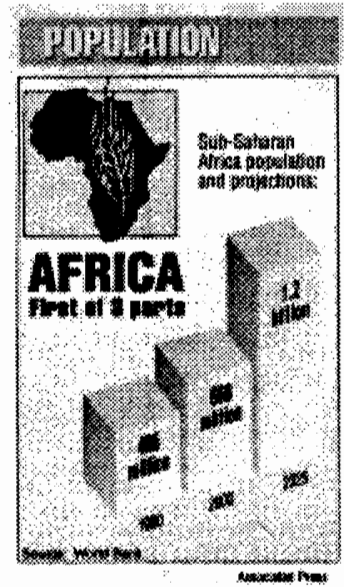

Figure 5. Africa: Population and Projections, 1990s. 


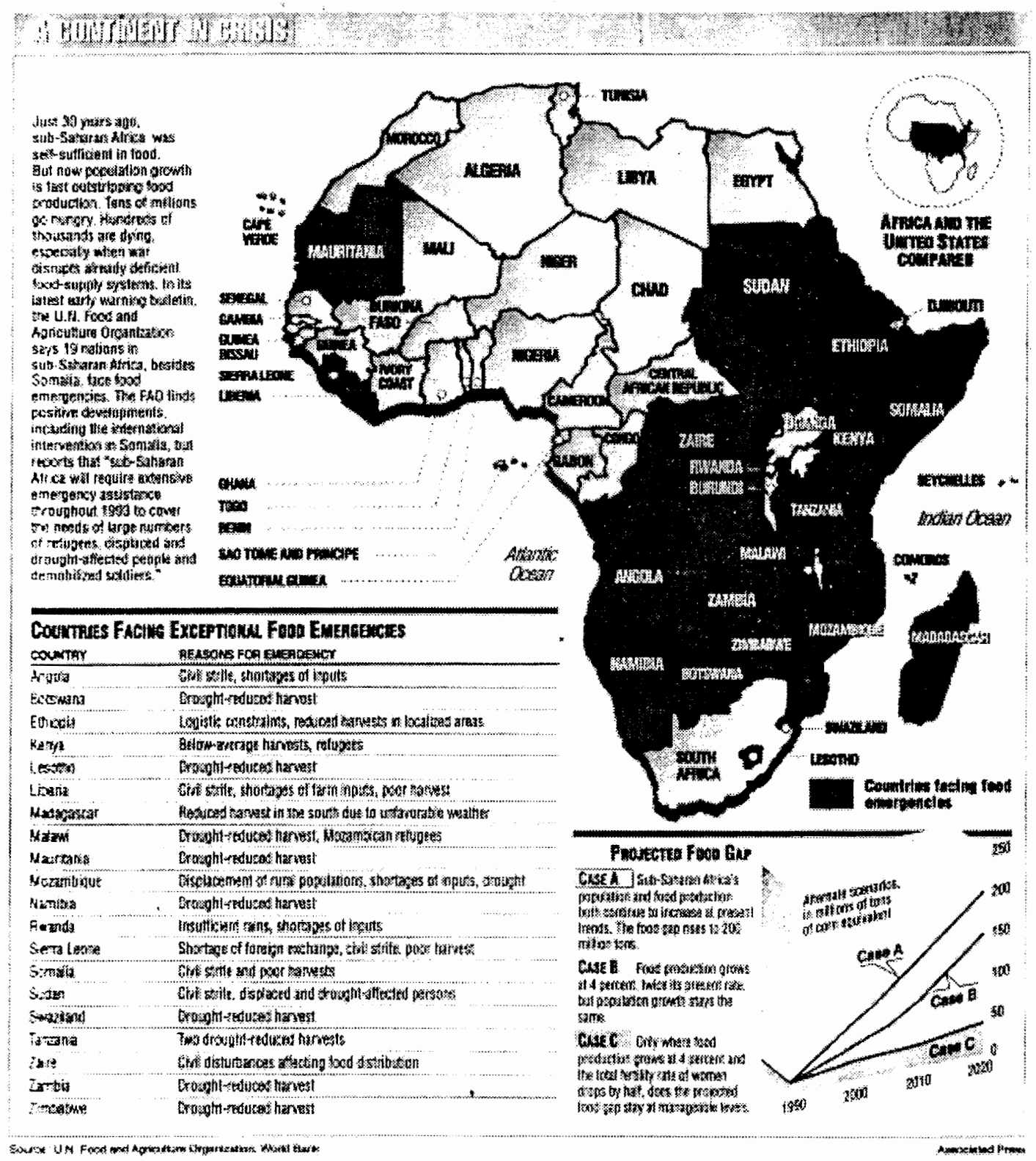

Figure 3. African Food Crisis Map. 
Gross Domestic Product at Factor Cost by Industrial Origin 1956-63

Composition of Total

Percentages

\begin{tabular}{|c|c|c|c|c|c|c|c|c|}
\hline Industry & 1956 & 1957 & 1958 & 1959 & 1960 & 1961 & 1962 & 1963 \\
\hline Ind Hunting & $\begin{array}{r}12.9 \\
4.0 \\
0.4 \\
0.8 \\
18.2\end{array}$ & $\begin{array}{r}11.6 \\
3.9 \\
0.3 \\
0.5 \\
16.3\end{array}$ & $\begin{array}{r}11.9 \\
4.0 \\
0.3 \\
0.4 \\
16.6\end{array}$ & $\begin{array}{r}11.8 \\
4.0 \\
0.4 \\
0.4 \\
16.6\end{array}$ & $\begin{array}{r}13.1 \\
4.1 \\
0.4 \\
0.2 \\
17.7\end{array}$ & $\begin{array}{r}12.6 \\
4.0 \\
0.4 \\
0.2 \\
17.2\end{array}$ & $\begin{array}{r}11.7 \\
3.9 \\
0.4 \\
0.3 \\
16.3\end{array}$ & $\begin{array}{r}12.8 \\
3.7 \\
0.3 \\
0.3 \\
17.1\end{array}$ \\
\hline $\begin{array}{l}\text { utside Recorded Mone } \\
\text { Agriculture } \\
\text { Livestock } \\
\text { Forestry } \\
\text { Fishing and Hunting } \\
\text { Total }\end{array}$ & $\begin{array}{r}18.0 \\
5.5 \\
1.2 \\
0.1 \\
24.9\end{array}$ & $\begin{array}{r}18.1 \\
5.7 \\
1.2 \\
0.1 \\
25.1\end{array}$ & $\begin{array}{r}18.3 \\
5.7 \\
1.2 \\
0.1 \\
25.3\end{array}$ & $\begin{array}{r}17.9 \\
5.4 \\
1.3 \\
0.1 \\
24.7\end{array}$ & $\begin{array}{r}16.0 \\
4.9 \\
1.3 \\
0.1 \\
22.3\end{array}$ & $\begin{array}{r}15.2 \\
4.6 \\
1.4 \\
0.1 \\
21.3\end{array}$ & $\begin{array}{r}19.0 \\
4.9 \\
1.9 \\
0.1 \\
25.9\end{array}$ & $\begin{array}{r}18.5 \\
4.9 \\
2.2 \\
0.1 \\
25.7\end{array}$ \\
\hline $\begin{array}{l}\text { arrying } \\
\text { Nater } \\
\text { age and Communi- }\end{array}$ & $\begin{array}{l}0.7 \\
9.4 \\
4.8 \\
0.9\end{array}$ & $\begin{array}{l}0.6 \\
9.6 \\
4.7 \\
1.0\end{array}$ & $\begin{array}{l}0.6 \\
9.9 \\
4.0\end{array}$ & $\begin{array}{l}0.5 \\
9.4 \\
3.7 \\
1.2\end{array}$ & $\begin{array}{l}0.5 \\
9.6 \\
3.5 \\
1.2\end{array}$ & $\begin{array}{r}0.4 \\
10.1 \\
3.5 \\
1.3\end{array}$ & $\begin{array}{l}0.3 \\
9.4 \\
2.8 \\
1.4\end{array}$ & $\begin{array}{l}0.3 \\
9.4 \\
1.9 \\
1.4\end{array}$ \\
\hline $\begin{array}{l}\text { al Estate } \\
\text { of }\end{array}$ & $\begin{array}{r}8.2 \\
13.4 \\
1.3 \\
5.6\end{array}$ & $\begin{array}{r}9.1 \\
13.3 \\
1.4 \\
5.9\end{array}$ & $\begin{array}{r}8.5 \\
12.7 \\
1.6 \\
6.3\end{array}$ & $\begin{array}{r}8.9 \\
12.9 \\
1.6 \\
6.8\end{array}$ & $\begin{array}{r}9.0 \\
12.8 \\
1.6 \\
6.9\end{array}$ & $\begin{array}{r}9.4 \\
13.2 \\
1.7 \\
6.3\end{array}$ & $\begin{array}{r}9.1 \\
12.3 \\
1.6 \\
5.8\end{array}$ & $\begin{array}{r}9.5 \\
12.3 \\
1.6 \\
5.9\end{array}$ \\
\hline & $\begin{array}{r}3.0 \\
47.3\end{array}$ & $\begin{array}{r}3.2 \\
48.8\end{array}$ & $\begin{array}{r}3.6 \\
48.3\end{array}$ & $\begin{array}{r}3.7 \\
48.7\end{array}$ & $\begin{array}{r}3.9 \\
49.0\end{array}$ & $\begin{array}{r}3.6 \\
49.4\end{array}$ & $\begin{array}{r}3.5 \\
46.2\end{array}$ & $\begin{array}{r}3.6 \\
46.0\end{array}$ \\
\hline nt & $\begin{array}{l}7.2 \\
1.2 \\
1.3\end{array}$ & $\begin{array}{l}7.5 \\
1.2 \\
1.0\end{array}$ & $\begin{array}{l}7.9 \\
1.4 \\
0.5\end{array}$ & $\begin{array}{l}7.9 \\
1.5 \\
0.7\end{array}$ & $\begin{array}{l}8.9 \\
1.5 \\
0.6\end{array}$ & $\begin{array}{l}9.6 \\
.1 .6 \\
0.8\end{array}$ & $\begin{array}{l}9.0 \\
1.7 \\
0.8\end{array}$ & $\begin{array}{l}8.1 \\
2.3 \\
0.7\end{array}$ \\
\hline $\begin{array}{l}\text { employ } \\
\text { Total }\end{array}$ & $\begin{array}{l}0.0 \\
9.7\end{array}$ & $\begin{array}{l}0.0 \\
9.8\end{array}$ & $\begin{array}{l}0.0 \\
9.8\end{array}$ & $\begin{array}{r}0.0 \\
10.0\end{array}$ & $\begin{array}{r}0.1 \\
11.1\end{array}$ & $\begin{array}{r}0.1 \\
12.0\end{array}$ & $\begin{array}{r}0.1 \\
11.5\end{array}$ & $\begin{array}{c}0.1 \\
11.1\end{array}$ \\
\hline Eco & 75.1 & 74.9 & 74.7 & 75.3 & 77.7 & 78.7 & 74.1 & 74.3 \\
\hline $\begin{array}{c}\text { Total-Gro } \\
\text { Product }\end{array}$ & 100 & 100 & 100 & 100 & 100 & 100 & 100 & 100 \\
\hline $\begin{array}{l}\text { Total Product Agriculture, etc. (inside } \\
\text { and outside recorded monetary } \\
\text { economy) } \\
\text { Arriculture } \\
\text { Livestock } \\
\text { Forestry } \\
\text { Fishing and Hunting }\end{array}$ & $\begin{array}{r}30.9 \\
9.5 \\
1.7 \\
1.0\end{array}$ & $\begin{array}{r}29.7 \\
9.6 \\
1.5 \\
0.6\end{array}$ & $\begin{array}{r}30.2 \\
9.6 \\
1.6 \\
0.5\end{array}$ & $\begin{array}{r}29.7 \\
9.4 \\
1.6 \\
0.5\end{array}$ & $\begin{array}{l}9.0 \\
1.7 \\
0.3\end{array}$ & $\begin{array}{r}27.8 \\
8.6 \\
1.8 \\
0.3\end{array}$ & $\begin{array}{r}30.7 \\
8.8 \\
2.3 \\
0.4\end{array}$ & $\begin{array}{r}31.3 \\
8.6 \\
2.5 \\
0.4\end{array}$ \\
\hline Total & 43.0 & 41.4 & 41.9 & 41.2 & 40.0 & $38: 5$ & 42.2 & 42.9 \\
\hline
\end{tabular}

Figure 6. Kenya's GDP from 1956 to 1963. 
Gross Domestic Product

Sector Shares (at constaot 1964 prices) 1964, 1969-73 (percentages)

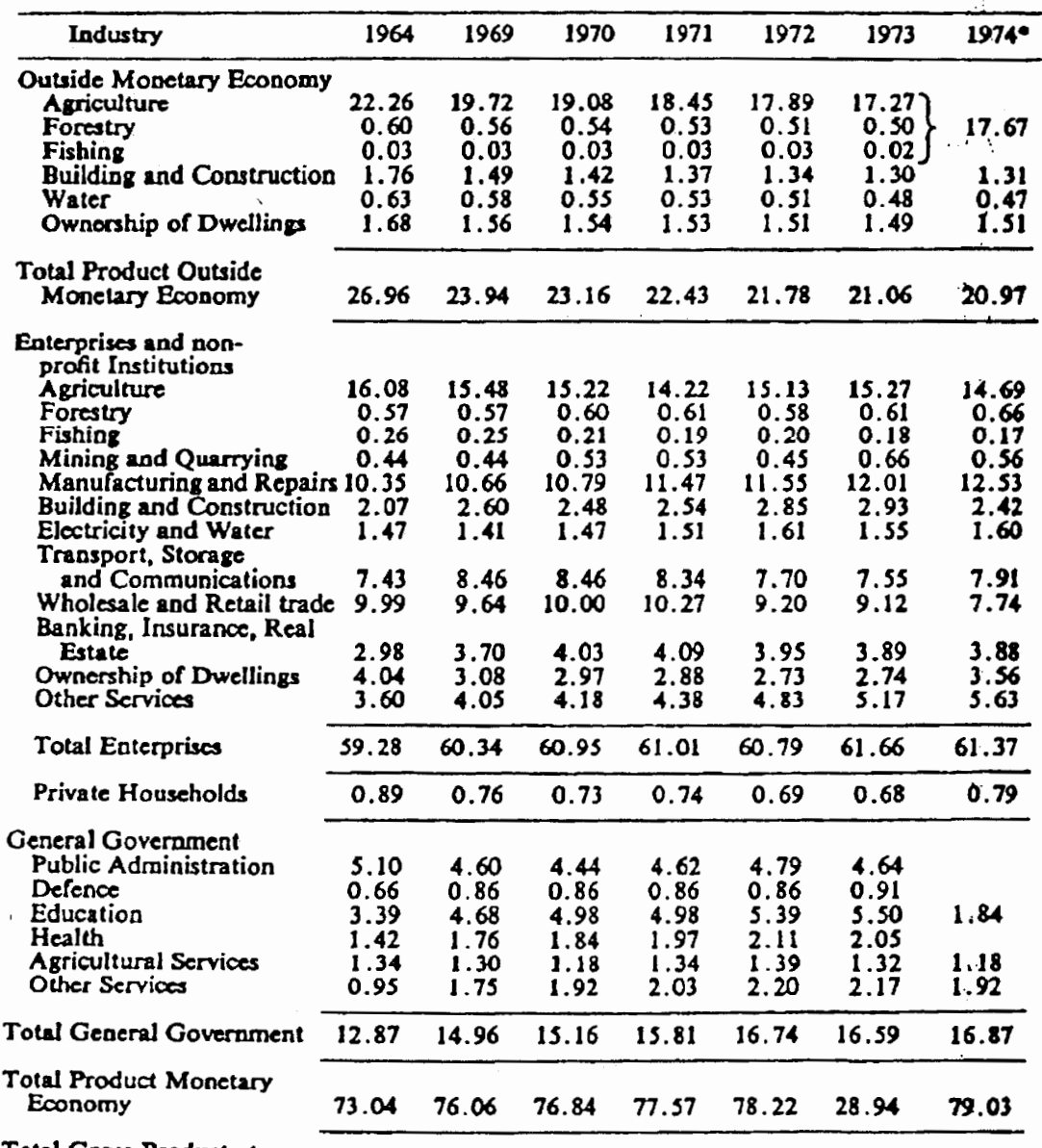

Total Gross Product at

Factor Cost (monetary

and non-monetary)

$\begin{array}{lllllll}100.00 & 100.00 & 100.00 & 100.00 & 100.00 & 100.00 & 100.00\end{array}$

- Provisional.

Source: Republic of Kenya, Economic Survey, 1975, p. 7.

Figure 7. Kenya's GDP: Sector Shares 1964, 1969-73.

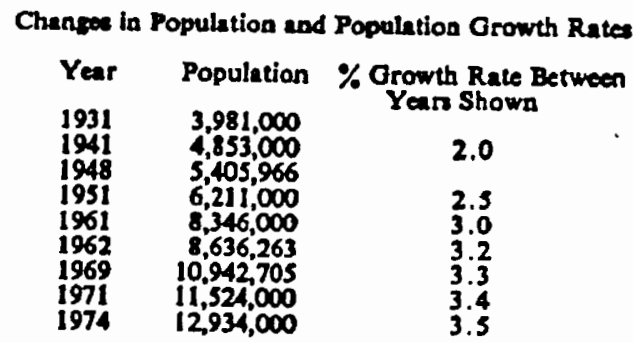

Sowrca: Republic of Kenyn, Development Plan 1974-78, p. S.

Figure 8. Kenya: Population and Growth Rates, 1931-1974. 
Kenya's Balance of Payments, 1968-74 (fm)

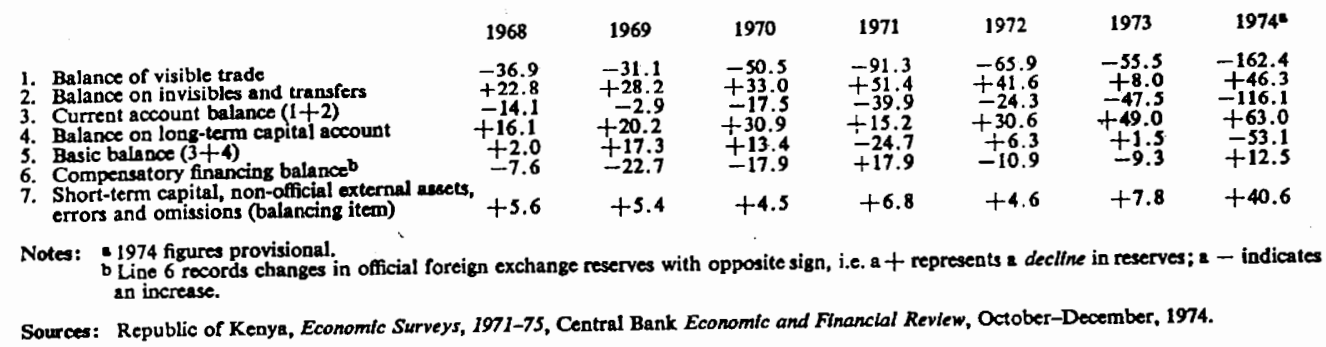

Figure 9. Kenya's Balance of Payments, 1968-74.

\begin{tabular}{|c|c|c|c|c|c|c|}
\hline \multirow[b]{3}{*}{$\begin{array}{l}\text { Imports } \\
\text { From outside E.A. of which } \\
\text { Commercial } \\
\text { Government } \\
\text { From Uganda and Tanzania }\end{array}$} & \multicolumn{6}{|c|}{ Balance of Trade 1969-74 (Kf million) } \\
\hline & 1969 & 1970 & 1971 & 1972 & 1973 & 1974 \\
\hline & $\begin{array}{r}117.0 \\
100.7 \\
16.3 \\
11.8\end{array}$ & $\begin{array}{r}142.0 \\
126.5 \\
15.5 \\
16.0\end{array}$ & $\begin{array}{r}184.1 \\
162.8 \\
21.3 \\
16.0\end{array}$ & $\begin{array}{r}177.6 \\
160.3 \\
17.3 \\
13.5\end{array}$ & $\begin{array}{r}205.8 \\
187.4 \\
18.4 \\
12.3\end{array}$ & $\begin{array}{r}353.0 \\
333.9 \\
19.1 \\
13.3\end{array}$ \\
\hline Total & 128.8 & 158.0 & 200.1 & 191.1 & 218.1 & 366.4 \\
\hline $\begin{array}{l}\text { Exports } \\
\text { To markets outside E.A. } \\
\text { To Uganda and Tanzania } \\
\text { Re-exports }\end{array}$ & $\begin{array}{r}63.3 \\
28.8 \\
5.2\end{array}$ & $\begin{array}{r}71.6 \\
31.4 \\
5.8\end{array}$ & $\begin{array}{l}73.2 \\
33.9 \\
5.2\end{array}$ & $\begin{array}{r}90.6 \\
32.8 \\
4.9\end{array}$ & $\begin{array}{l}122.6 \\
38.8 \\
6.3\end{array}$ & $\begin{array}{r}162.9 \\
48.3 \\
7.2\end{array}$ \\
\hline Total & 97.3 & 108.8 & 112.3 & 128.2 & 167.7 & 218.4 \\
\hline $\begin{array}{l}\text { Balance of Trade } \\
\text { With markets outside E.A. } \\
\text { With Uganda and Tanzania }\end{array}$ & $\begin{array}{r}-48.5 \\
17.0\end{array}$ & $\begin{array}{r}-64.6 \\
15.4\end{array}$ & $\begin{array}{r}-105.7 \\
17.9\end{array}$ & $\begin{array}{r}-82.2 \\
19.3\end{array}$ & $\begin{array}{r}-76.9 \\
26.5\end{array}$ & $\begin{array}{r}-182.9 \\
35.0\end{array}$ \\
\hline Total & -31.5 & -49.2 & -87.8 & -62.9 & -50.4 & -147.9 \\
\hline
\end{tabular}

Source: Republic of Kenya, Economic Survey, 1974 and 1975.

Figure 10. Kenya's Balance of Trade, 1969-74.

\begin{tabular}{|c|c|c|c|c|c|}
\hline \multirow[b]{3}{*}{$\begin{array}{l}\text { External Trado } \\
\text { Inter-tertitorial Trade }\end{array}$} & Trade & $70-74($ & $4-1$ & & \\
\hline & 1970 & 1971 & 1972 & 1973 & 1974. \\
\hline & $\begin{array}{r}97 \\
102\end{array}$ & $\begin{array}{r}85 \\
112\end{array}$ & $\begin{array}{r}82 \\
106\end{array}$ & $\begin{array}{r}85 \\
111\end{array}$ & $\begin{array}{r}68 \\
109\end{array}$ \\
\hline Total & 99 & 93 & 91 & 92 & 75 \\
\hline
\end{tabular}

Source: Republic of Kenya, Economic Survey, 1975, p. 74.

Figure 11. Kenya's Terms of Trade 1970-74. 
Kenya's Domestic Exports Principal Commodities 1964-73 Percentage of Total Value

\begin{tabular}{|c|c|c|c|c|c|c|c|c|c|c|}
\hline Commodity & 1964 & 1965 & 1966 & 1967 & 1968 & 1969 & 1970 & 1971 & 1972 & 1973 \\
\hline $\begin{array}{l}\text { Coffee, not roasted } \\
\text { Tea } \\
\text { Sisal fibre and tow } \\
\text { Meat and meat preparations } \\
\text { Pyrethrum extract and flowers } \\
\text { Hides, skins, and furskins, undressed } \\
\text { Maize, unmilled } \\
\text { Wattle bark and extract } \\
\text { Pineapples, tinned } \\
\text { Cotton, raw } \\
\text { Wool, raw } \\
\text { Cashew nuts } \\
\text { Beans, peas and lentils } \\
\text { Oil seeds, oilnuts and oil kernels } \\
\text { Butter and gheo }\end{array}$ & $\begin{array}{r}32.7 \\
12.9 \\
12.8 \\
4.6 \\
5.2 \\
2.7 \\
2.3 \\
1.9 \\
1.4 \\
1.1 \\
0.6 \\
1.1 \\
1.0 \\
1.6\end{array}$ & $\begin{array}{l}29.9 \\
12.9 \\
8.2 \\
5.2 \\
4.7 \\
3.7 \\
1.8 \\
1.6 \\
1.6 \\
1.2 \\
1.2 \\
1.0 \\
1.0 \\
0.6\end{array}$ & $\begin{array}{r}32.3 \\
15.0 \\
5.8 \\
5.2 \\
4.9 \\
4.4 \\
2.7 \\
0.9 \\
1.5 \\
1.0 \\
0.8 \\
1.0 \\
0.9 \\
0.7\end{array}$ & $\begin{array}{l}29.3 \\
13.8 \\
3.9 \\
5.3 \\
5.4 \\
3.3 \\
2.6 \\
1.7 \\
1.0 \\
1.2 \\
0.9 \\
1.0 \\
0.6 \\
0.7 \\
0.5\end{array}$ & $\begin{array}{r}22.2 \\
17.4 \\
3.2 \\
5.2 \\
5.3 \\
2.9 \\
8.3 \\
2.1 \\
0.8 \\
0.7 \\
1.0 \\
1.1 \\
1.4 \\
1.1 \\
0.6\end{array}$ & $\begin{array}{r}26.6 \\
17.8 \\
2.7 \\
4.1 \\
4.4 \\
3.0 \\
4.4 \\
1.9 \\
1.1 \\
1.2 \\
0.9 \\
1.1 \\
0.8 \\
0.5 \\
0.4\end{array}$ & $\begin{array}{r}31.1 \\
17.7 \\
2.6 \\
4.0 \\
3.0 \\
2.3 \\
-1.6 \\
0.9 \\
1.7 \\
0.5 \\
2.2 \\
0.7 \\
0.7 \\
0.3\end{array}$ & $\begin{array}{l}26.8 \\
16.2 \\
2.1 \\
5.0 \\
4.6 \\
3.3 \\
1.6 \\
1.3 \\
1.6 \\
0.4 \\
1.0 \\
0.6 \\
0.6 \\
0.1\end{array}$ & $\begin{array}{r}27.3 \\
18.1 \\
2.3 \\
5.4 \\
5.0 \\
4.2 \\
-1.9 \\
1.0 \\
1.3 \\
0.4 \\
1.2 \\
1.2 \\
0.3 \\
0.8\end{array}$ & $\begin{array}{l}29.2 \\
13.8 \\
3.9 \\
3.1 \\
3.0 \\
4.2 \\
4.6 \\
1.0 \\
1.2 \\
1.1 \\
0.7 \\
0.5 \\
1.0 \\
0.4 \\
0.6\end{array}$ \\
\hline $\begin{array}{l}\text { Non-agricultural } \\
\text { Other }\end{array}$ & $\begin{array}{l}9.7 \\
8.5\end{array}$ & $\begin{array}{r}16.4 \\
9.1\end{array}$ & $\begin{array}{r}14.9 \\
8.0\end{array}$ & $\begin{array}{l}18.3 \\
10.5\end{array}$ & $\begin{array}{l}15.3 \\
11.4\end{array}$ & $\begin{array}{l}16.3 \\
12.8\end{array}$ & $\begin{array}{l}16.7 \\
14.0\end{array}$ & $\begin{array}{l}19.7 \\
15.1\end{array}$ & $\begin{array}{l}14.7 \\
14.9\end{array}$ & $\begin{array}{l}12.5 \\
19.2\end{array}$ \\
\hline Total & 1000 & 100.0 & 100.0 & 100.0 & 100.0 & 100.0 & 100.0 & 100.0 & 100.0 & 100.0 \\
\hline
\end{tabular}

Source: Annual Trade Reports, East African Customs and Excise Department and adapted from Republic of Kenya, Statistlcal Abstract, 1974.

Figure 12. Kenya: Domestic Exports by Principal Commodities, 1964-73.

\begin{tabular}{c|c|c|c}
\multicolumn{4}{c}{$\begin{array}{c}\text { Cofiee Production, 1963-74 } \\
\text { ('OO0 metric tons) }\end{array}$} \\
\cline { 2 - 4 } Year & $\begin{array}{c}\text { Estates } \\
\text { Production }\end{array}$ & $\begin{array}{c}\text { Small-holdings } \\
\text { Production }\end{array}$ & $\begin{array}{c}\text { Total } \\
\text { Production }\end{array}$ \\
\hline 1964 & 24.8 & 16.6 & 41.4 \\
1965 & 23.1 & 16.2 & 39.3 \\
1966 & 28.4 & 28.5 & 56.9 \\
1967 & 19.2 & 28.8 & 48.0 \\
1968 & 18.8 & 20.8 & 39.6 \\
1969 & 26.8 & 25.6 & 52.4 \\
1970 & 27.9 & 30.4 & 58.3 \\
1971 & 31.5 & 28.0 & 59.5 \\
1972 & 34.2 & 27.8 & 62.0 \\
1973 & 35.1 & 36.1 & 71.2 \\
1974 & 30.8 & 39.3 & 70.1 \\
\hline
\end{tabular}

Source: Republic of Kenya, Economic Survey, 1969 and 1975.

Figure 13. Kenya's Coffee Production, 1963-74.

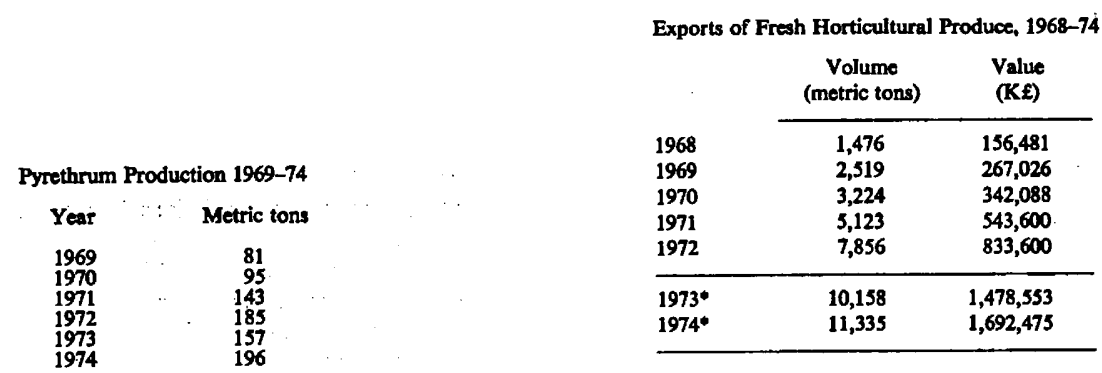

Sonree: Republic of Kenya, Economic Survey, 1974 and $1975 . \quad$ In 1973 a separate valuation was introduced for cut flowers. The 1973 and 1974 value

Figure 15. Kenya's Pyrethrum Production, 1969-74. figures are therefore not comparable with previous years.

Soarce: Republic of Kenya, Economic Survey, 1974 and 1975.

The Development of Smallholder Tea 1964-74

\begin{tabular}{c|c|c}
\hline & $\begin{array}{c}\text { Total Hectares } \\
\text { at end of year }\end{array}$ & $\begin{array}{c}\text { Number of Grower } \\
\text { at end of year }\end{array}$ \\
\cline { 1 - 3 } Up to $1964 / 65$ & 5,133 & 22,343 \\
$1965 / 66$ & 6,479 & 29,693 \\
$1966 / 67$ & 8,424 & 32,599 \\
$1967 / 68$ & 10,772 & 37,953 \\
$1968 / 69$ & 13,409 & 42,596 \\
$1969 / 70$ & 16,229 & 48,443 \\
$1970 / 71$ & 19,230 & 53,400 \\
$1971 / 72$ & 26,228 & 66,897 \\
$1972 / 73$ & 30,895 & 79,314 \\
$1973 / 74$ & 34,384 & 90,135 \\
\hline
\end{tabular}

Somes: Republic of Kenya, Economic Survey, 1975, p. 98.

Figure 14. Kenya: The Development of Smallholder Tea, 1964-74.

Figure 16. Kenya: Exports of Fresh

Horticultural Produce, 1968-74. 


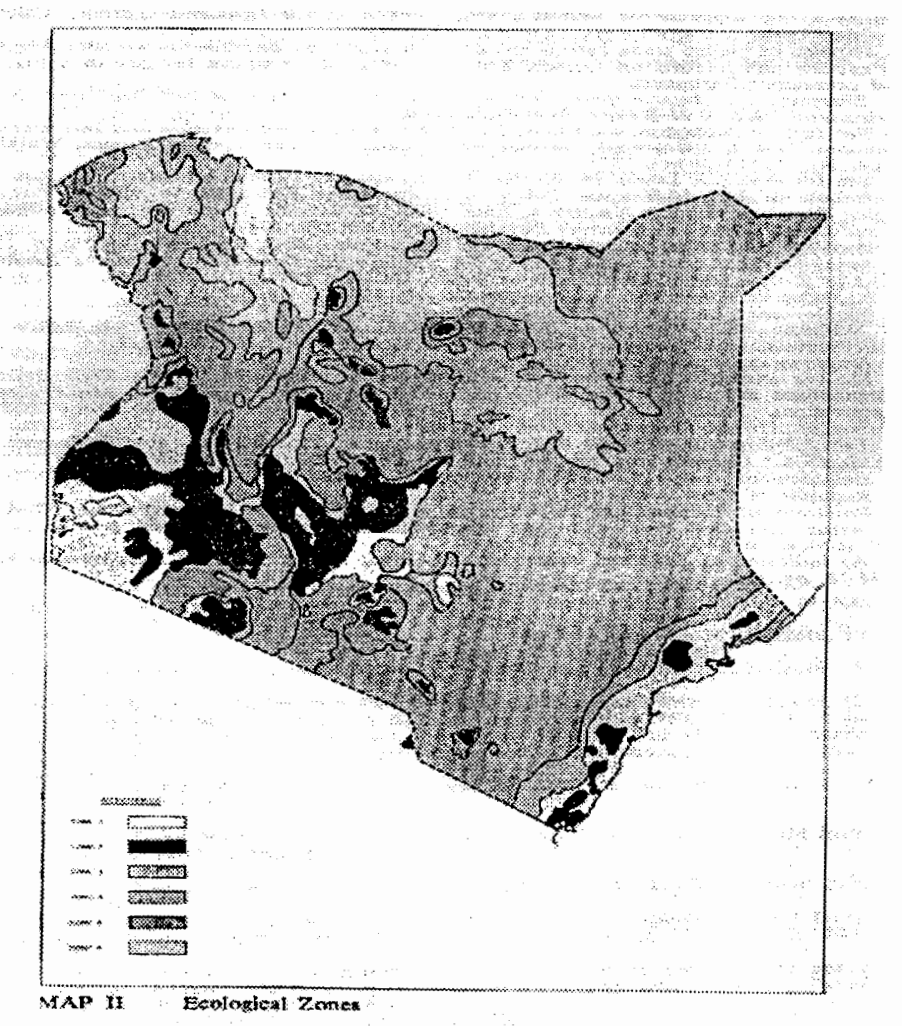

Figure 17. Ecological Zones of Kenya.

\begin{tabular}{|c|c|c|c|c|c|}
\hline \multicolumn{6}{|c|}{ Import Price Index, 1970-74 $(1964-100)$} \\
\hline Overseas Imports & 1970 & 1971 & 1972 & 1973 & 1974 \\
\hline $\begin{array}{l}\text { Food } \\
\text { Beverages and tobacco } \\
\text { Basic materials, inedible } \\
\text { Mineral fuels } \\
\text { Animal and vegetable oils and fats } \\
\text { Chemicals } \\
\text { Textiles } \\
\text { Metals } \\
\text { Semi-manufactures } \\
\text { Machinery and transport equipment } \\
\text { Consumer goods }\end{array}$ & $\begin{array}{r}84 \\
137 \\
117 \\
105 \\
133 \\
92 \\
138 \\
113 \\
119 \\
101 \\
115\end{array}$ & $\begin{array}{r}92 \\
143 \\
127 \\
106 \\
131 \\
95 \\
173 \\
117 \\
117 \\
114 \\
129\end{array}$ & $\begin{array}{l}104 \\
160 \\
131 \\
120 \\
124 \\
102 \\
174 \\
126 \\
129 \\
138 \\
140\end{array}$ & $\begin{array}{l}136 \\
176 \\
138 \\
133 \\
168 \\
134 \\
203 \\
159 \\
150 \\
151 \\
155\end{array}$ & $\begin{array}{l}191 \\
176 \\
186 \\
433 \\
313 \\
302 \\
274 \\
243 \\
233 \\
171 \\
229\end{array}$ \\
\hline Total Overseas Imports & 107 & 117 & 130 & 150 & 247 \\
\hline $\begin{array}{l}\text { East African Imports } \\
\text { Food and live animals } \\
\text { Beverages and tobacco } \\
\text { Crude materials, inedible } \\
\text { Electric energy and residual fuel oils } \\
\text { Animal and vegetable oils and fats } \\
\text { Chemicals } \\
\text { Textile yarn, fabrics, made-up articles and } \\
\text { reiated products } \\
\text { Metals and metal manufactures } \\
\text { Rubber, paper and paper products } \\
\text { Consumer goods }\end{array}$ & $\begin{array}{r}109 \\
127 \\
113 \\
85 \\
134 \\
118 \\
92 \\
124 \\
107 \\
91\end{array}$ & $\begin{array}{r}127 \\
121 \\
115 \\
87 \\
163 \\
116 \\
89 \\
128 \\
110 \\
67\end{array}$ & $\begin{array}{r}164 \\
99 \\
137 \\
82 \\
195 \\
116 \\
109 \\
132 \\
109 \\
74\end{array}$ & $\begin{array}{l}188 \\
124 \\
153 \\
77 \\
174 \\
133 \\
121 \\
140 \\
126 \\
90\end{array}$ & $\begin{array}{l}199 \\
164 \\
193 \\
84 \\
272 \\
163 \\
181 \\
181 \\
161 \\
119\end{array}$ \\
\hline Total East African Imports & 111 & 113 & 133 & 144 & 187 \\
\hline All Imports & 107 & 117 & 131 & 150 & 241 \\
\hline
\end{tabular}

Source: Republic of Kenya, Economic Survey, 1975, p. 72.

Figure 18. Kenya: Import Price Index, 1970-74. 


\begin{tabular}{|c|c|c|c|c|c|}
\hline \multicolumn{6}{|c|}{ Export Prico Iadex, 1970-74 (1964-100) } \\
\hline Overeass Exports & 1970 & 1971 & 1972 & 1973 & 1974 \\
\hline 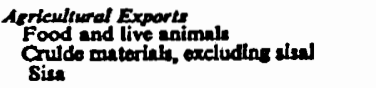 & $\begin{array}{r}112 \\
100 \\
40\end{array}$ & $\begin{array}{r}103 \\
103 \\
41\end{array}$ & $\begin{array}{r}109 \\
114 \\
52\end{array}$ & $\begin{array}{l}124 \\
149 \\
101\end{array}$ & $\begin{array}{l}135 \\
156 \\
223\end{array}$ \\
\hline Total A ricultural Exports & 104 & 96 & 105 & 125 & 152 \\
\hline $\begin{array}{l}\text { Orher Expotra } \\
\text { Miperal fuals, lubricants and ralated } \\
\text { materials } \\
\text { Chemicals } \\
\text { Manuractured goods }\end{array}$ & $\begin{array}{r}107 \\
123 \\
86\end{array}$ & $\begin{array}{r}108 \\
136 \\
99\end{array}$ & $\begin{array}{l}106 \\
145 \\
110\end{array}$ & $\begin{array}{l}117 \\
156 \\
128\end{array}$ & $\begin{array}{l}360 \\
197 \\
172\end{array}$ \\
\hline Total Overueas Exports & 103 & 99 & 107 & 127 & 160 \\
\hline East African Exports & & & & & \\
\hline $\begin{array}{l}\text { Food and live animals } \\
\text { Bovoraces and tobaces } \\
\text { Crude materials inedible } \\
\text { Mineril fuela and lubricants } \\
\text { Animal and vesotable oils and fat } \\
\text { Cbenicals }\end{array}$ & $\begin{array}{l}125 \\
86 \\
128 \\
911 \\
111 \\
102\end{array}$ & $\begin{array}{l}128 \\
153 \\
147 \\
106 \\
163 \\
94\end{array}$ & $\begin{array}{l}125 \\
164 \\
122 \\
111 \\
152 \\
122\end{array}$ & $\begin{array}{l}137 \\
173 \\
149 \\
125 \\
198 \\
135\end{array}$ & $\begin{array}{l}186 \\
146 \\
196 \\
265 \\
3 T 1 \\
152\end{array}$ \\
\hline 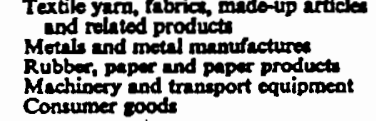 & $\begin{array}{l}94 \\
115 \\
111 \\
182 \\
139\end{array}$ & $\begin{array}{l}101 \\
130 \\
133 \\
211 \\
153\end{array}$ & $\begin{array}{l}175 \\
152 \\
148 \\
220 \\
178\end{array}$ & $\begin{array}{l}158 \\
159 \\
168 \\
278 \\
251\end{array}$ & $\begin{array}{l}265 \\
190 \\
239 \\
216 \\
223\end{array}$ \\
\hline Total East Aftican Exports & 113 & 126 & 141 & 160 & 204 \\
\hline All Exports Excludias Gold & 107 & 109 & 119 & 138 & 180 \\
\hline
\end{tabular}

Saurea: Republic of Kenya, Economic Surney, 1975, p. 73.

Figure 19. Kenya: Export Price Index, 1970-74.

Net Food Imports 1964-73 (Kf'000)

\begin{tabular}{|c|c|c|c|c|c|c|c|c|c|c|}
\hline Article & 1964 & 1965 & 1966 & 1967 & 1968 & 1969 & 1970 & 1971 & 1972 & 1973 \\
\hline $\begin{array}{l}\text { ood and Live Animals } \\
\text { Milk, evaporated or condensed } \\
\text { Milk, dry } \\
\text { Fisb and fish preparations } \\
\text { Wheat, unmilled } \\
\text { Maize, unmilled } \\
\text { Rice } \\
\text { Malt } \\
\text { Fruit and vegetables } \\
\text { Sugar refined, beet and cane } \\
\text { Sugar confoctionery } \\
\text { Chocolate and cocoa products } \\
\text { Tea } \\
\text { All other foods } \\
\text { Total }\end{array}$ & $\begin{array}{r}25 \\
208 \\
149 \\
12 \\
50 \\
186 \\
527 \\
1,744 \\
130 \\
143 \\
1,667 \\
1,006 \\
5,867\end{array}$ & $\begin{array}{r}1 \\
206 \\
171 \\
155 \\
2,305 \\
155 \\
163 \\
681 \\
2,163 \\
174 \\
118 \\
1,786 \\
1,539 \\
9,617\end{array}$ & $\begin{array}{r}418 \\
393 \\
655 \\
3,692 \\
150 \\
145 \\
652 \\
2,848 \\
173 \\
165 \\
1,192 \\
1,521 \\
12,004\end{array}$ & $\begin{array}{r}355 \\
364 \\
155 \\
6 \\
-15 \\
156 \\
672 \\
511 \\
151 \\
144 \\
806 \\
1,248 \\
4,553\end{array}$ & $\begin{array}{r}158 \\
392 \\
\frac{3}{3} \\
343 \\
213 \\
551 \\
624 \\
205 \\
106 \\
853 \\
1,420 \\
4,868\end{array}$ & $\begin{array}{r}171 \\
80 \\
5 \\
-31 \\
116 \\
503 \\
324 \\
141 \\
168 \\
569 \\
1,184 \\
3,230\end{array}$ & $\begin{array}{l}\overline{330} \\
127 \\
387 \\
101 \\
204 \\
638 \\
935 \\
174 \\
131 \\
881 \\
1,644 \\
5,552\end{array}$ & $\begin{array}{r}4 \overline{425} \\
67 \\
297 \\
898 \\
713 \\
209 \\
609 \\
3,768 \\
235 \\
211 \\
1,446 \\
2,132 \\
11,010\end{array}$ & $\begin{array}{r}363 \\
-52 \\
1,584 \\
10 \\
36 \\
356 \\
776 \\
7,053 \\
77 \\
134 \\
974 \\
1,520 \\
12,836\end{array}$ & $\begin{array}{r}\overline{49} \\
91 \\
3,597 \\
10 \\
81 \\
432 \\
6,732 \\
29 \\
102 \\
607 \\
2,427 \\
14,157\end{array}$ \\
\hline
\end{tabular}

Source: Republic of Kenya, Statistical Abstract, 1974, p. 73.

Figure 20. Kenya: Net Food imports 1964-73.

Deliveries of Sheep, Lambs and Goats • to the KMC 1966-74 ("000 head)

\begin{tabular}{|c|c|c|c|}
\hline & Sheep & Lambs & Goats \\
\hline $\begin{array}{l}1966 \\
1967 \\
1968 \\
1969 \\
1970 \\
1971 \\
1972 \\
1973 \\
1974\end{array}$ & $\begin{array}{r}41.8 \\
39.2 \\
31.3 \\
49.0 \\
50.4 \\
37.8 \\
33.2 \\
12.4 \\
6.6\end{array}$ & $\begin{array}{r}7.8 \\
7.6 \\
9.5 \\
11.6 \\
14.4 \\
15.3 \\
21.5 \\
5.4 \\
4.8\end{array}$ & $\begin{array}{r}13.3 \\
19.9 \\
12.3 \\
38.4 \\
47.3 \\
46.8 \\
46.5 \\
17.7 \\
6.5\end{array}$ \\
\hline
\end{tabular}

Source: Republic of Kenya, Economic Survey, 1974 and 1975.

Figure 21. Kenya: Delivery of Sheep, Lambs and Goats, 1966-74. 


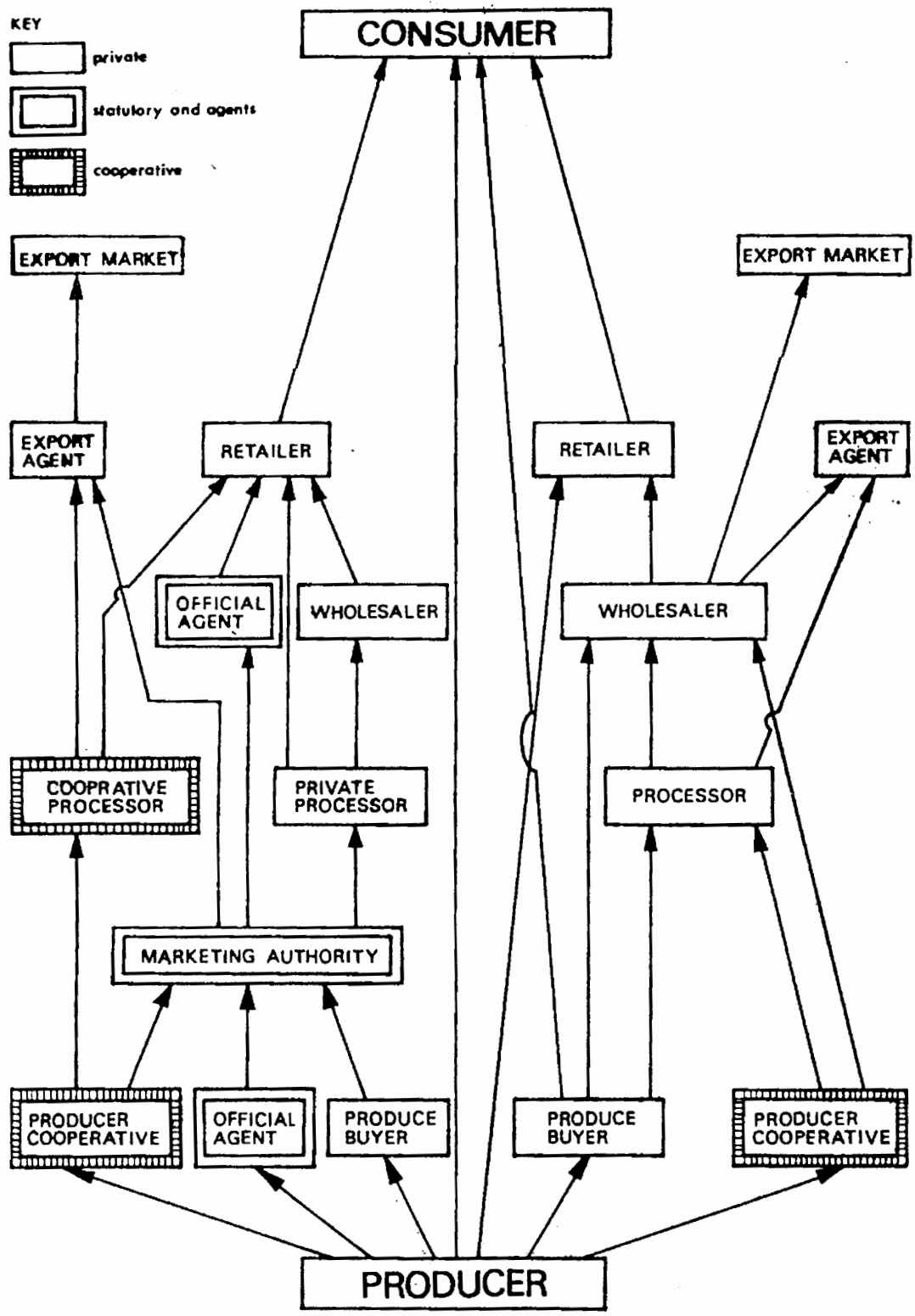

MARKETINC CHAINE IN KENYA

Figure 22. Kenya's Marketing Network. 

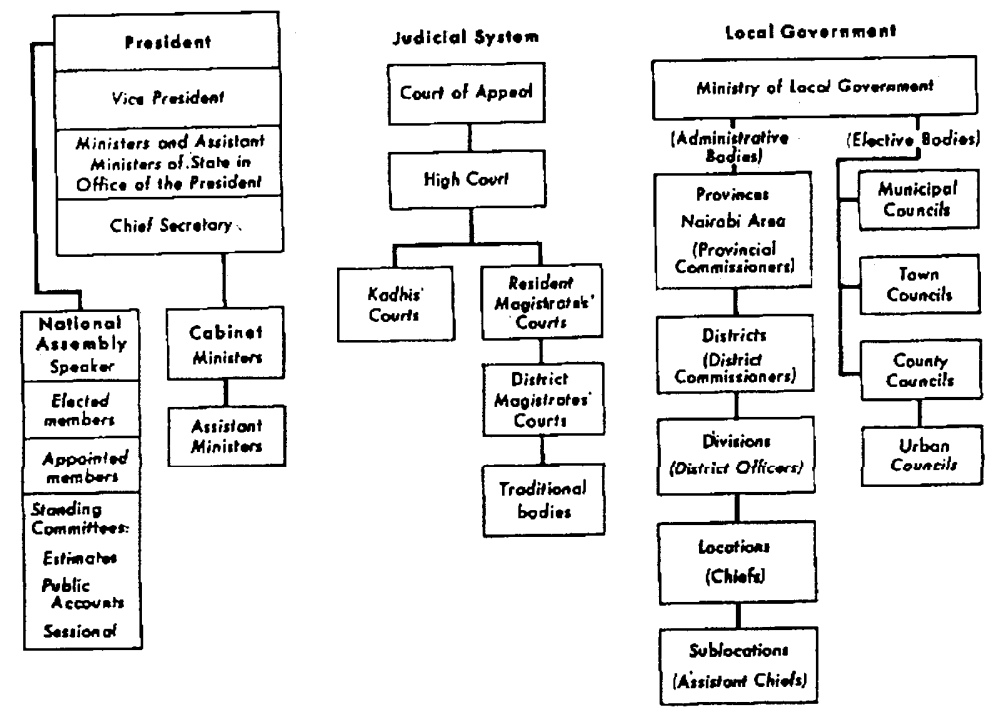

Figure 23. Organization of the Kenya Government, 1983.

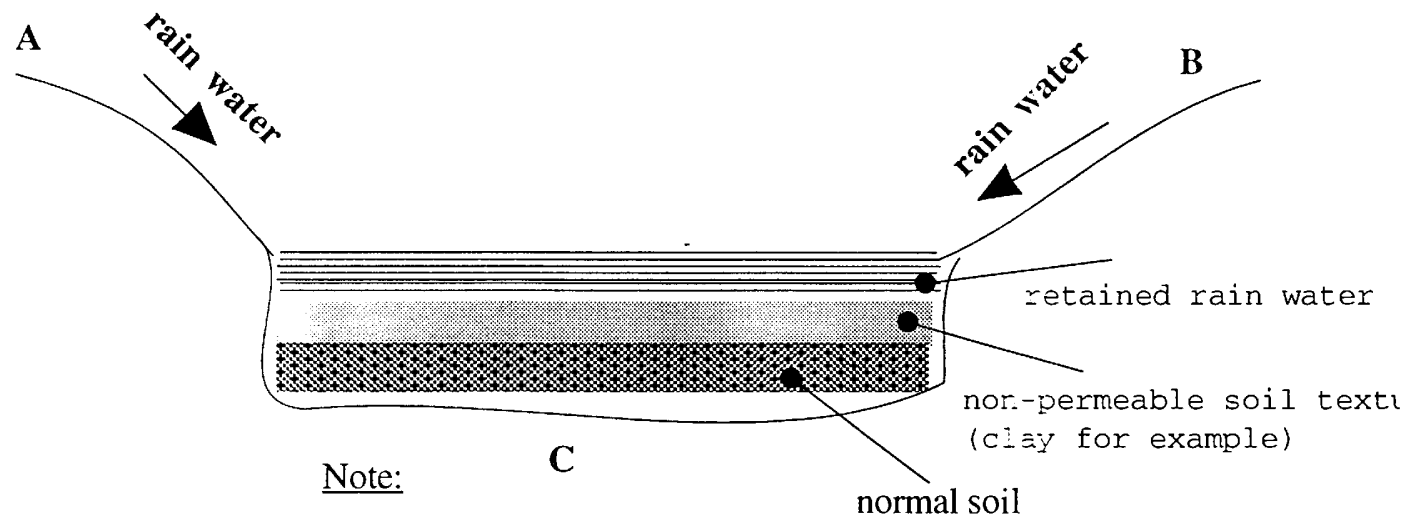

$A$ and $\mathbf{B}$ are points with higher elevation

$\mathrm{C}$ is a point with lowest elevation in the area (The rain water retention reservoir must be dug at this point.)

Figure 24. Rain water retention reservoir. 


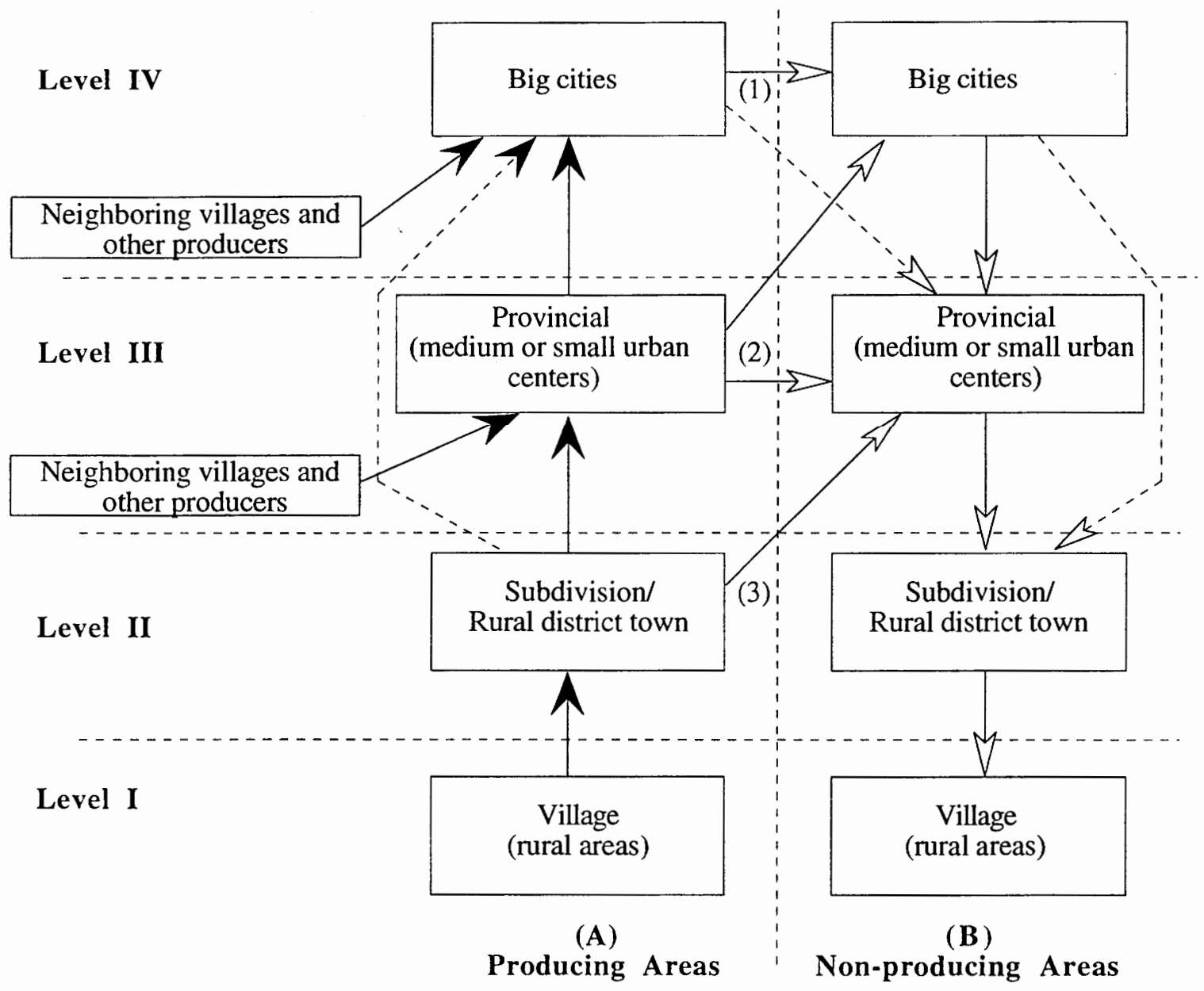

\section{Notes:}

(1) and (2): Sale of produce only to licensed distribution and retail companies

(3) Sale of produce to licensed distribution companies, local retailers, and popular market.

Figure 25. A layered distribution model for foodstuffs. 


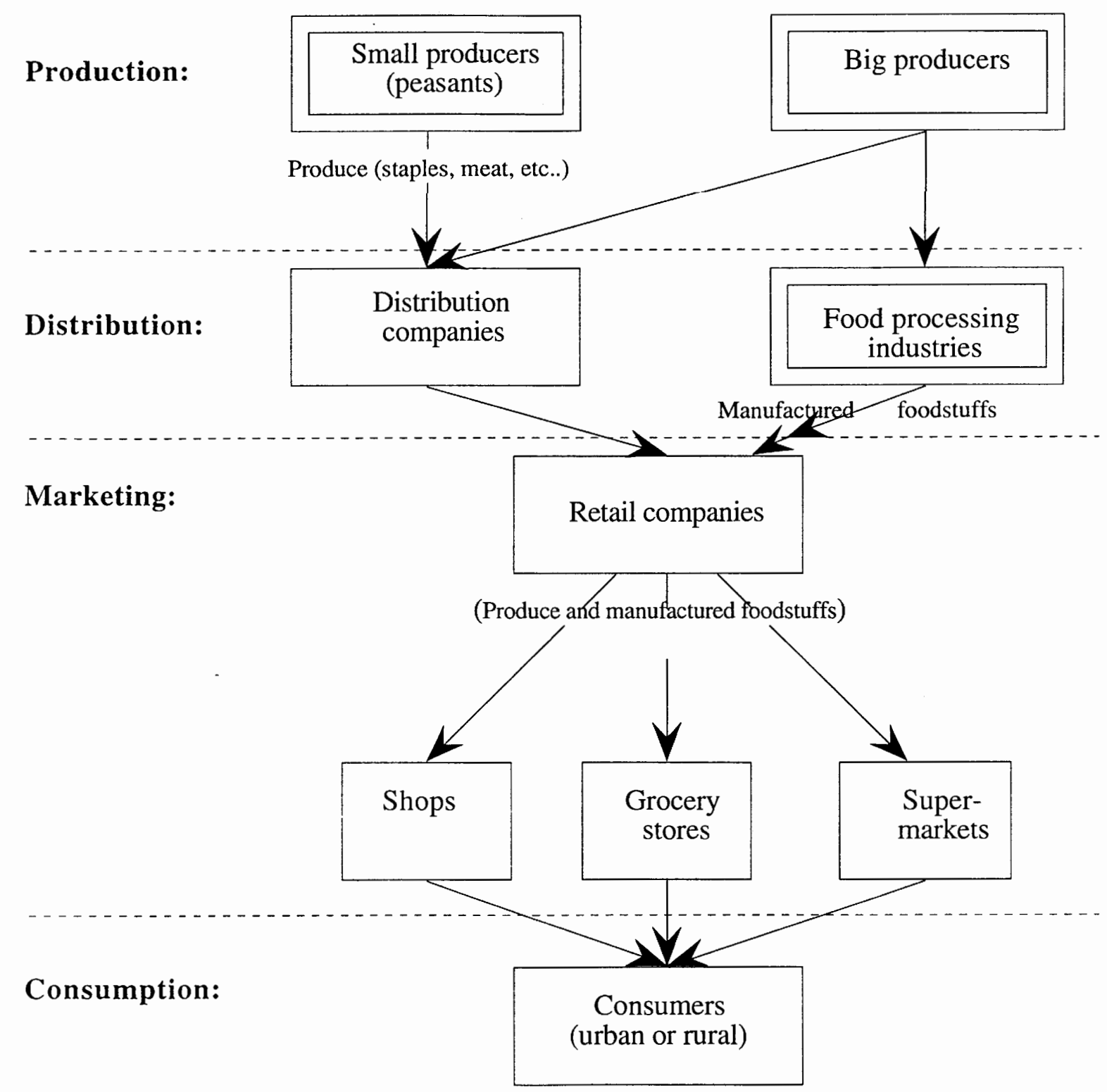

Figure 26. A layered model system for production, distribution, and marketing for foodstuffs. 